UNIVERSIDADE DE SÃO PAULO

FACULDADE DE FILOSOFIA, LETRAS E CIÊNCIAS HUMANAS

DEPARTAMENTO DE LETRAS CLÁSSICAS E VERNÁCULAS

PROGRAMA DE PÓS-GRADUAÇÃO EM FILOLOGIA E

LIINGUA PORTUGUESA

ELIANA VASCONCELOS DA SILVA ESVAEL

A construção do ponto de vista dominante na escrita de

pré-universitários

VERSÃO CORRIGIDA

(Exemplar original disponível no Centro de Apoio à Pesquisa

Histórica - CAPH - da FFLCH)

SÃO PAULO 


\section{A CONSTRUÇÃO DO PONTO DE VISTA DOMINANTE NA ESCRITA DE PRÉ-UNIVERSITÁRIOS}

Tese de doutorado apresentada ao Programa de Pós-graduação em Filologia e Língua Portuguesa do Departamento de Letras Clássicas e Vernáculas da Faculdade de Filosofia, Letras e Ciências Humanas da Universidade de São Paulo, para a obtenção do título de doutor em Letras.

Área de Concentração: Filologia e Língua Portuguesa

Orientador: Prof. Dr. Manoel Luiz Gonçalves Corrêa

São Paulo 
AUTORIZO A REPRODUÇÃO E DIVULGAÇÃO TOTAL OU PARCIAL DESTE TRABALHO, POR QUALQUER MEIO CONVENCIONAL OU ELETRÔNICO, PARA FINS DE ESTUDO E PESQUISA, DESDE QUE CITADA A FONTE.

\section{VERSÃO CORRIGIDA \\ (Exemplar original disponível no Centro de Apoio à Pesquisa \\ Histórica - CAPH - da FFLCH)}

Catalogação na Publicação

Serviço de Biblioteca e Documentação

Faculdade de Filosofia, Letras e Ciências Humanas da Universidade de São Paulo

\begin{tabular}{|c|c|}
\hline E82c & $\begin{array}{l}\text { Esvael, Eliana Vasconcelos da Silva } \\
\text { A construção do ponto de vista dominante na escrita de pré- } \\
\text { universitários / Eliana Vasconcelos da Silva Esvael; orientador } \\
\text { Manoel Luiz Gonçalves Corrêa. - São Paulo, } 2011 \text {. } \\
\quad 244 \mathrm{f} \text {. }\end{array}$ \\
\hline & $\begin{array}{l}\text { Tese (Doutorado) - Faculdade de Filosofia, Letras e Ciências } \\
\text { Humanas da Universidade de São Paulo. Departamento de Letras } \\
\text { Clássicas e Vernáculas. Área de concentração: Filologia e Língua } \\
\text { Portuguesa. }\end{array}$ \\
\hline & $\begin{array}{l}\text { 1. escrita. 2. redação de vestibular. } 3 \text {. estratégias } \\
\text { argumentativas. } 4 \text {. mobilização de saberes. } 5 \text {. construção de pontos } \\
\text { de vista. I. Corrêa, Manoel Luiz Gonçalves, orient. II. Título. }\end{array}$ \\
\hline
\end{tabular}




\section{ELIANA VASCONCELOS DA SILVA ESVAEL}

\section{A Construção do ponto de vista dominante da escrita de pré-universitários}

Tese de doutorado apresentada ao Programa de Pós-graduação em Filologia e Língua Portuguesa do Departamento de Letras Clássicas e Vernáculas da Faculdade de Filosofia, Letras e Ciências Humanas da Universidade de São Paulo, para a obtenção do título de doutor em Letras.

Orientador: Prof. Dr. Manoel Luiz Gonçalves Corrêa

Aprovado em: 31 de janeiro de 2012

\section{Banca Examinadora}

Prof. Dr. Manoel Gonçalves Corrêa (Presidente) FFLCH - Universidade de São Paulo

Assinatura:

Prof ${ }^{a}$. Dr ${ }^{\mathrm{a}}$. Helena Hathsue Nagamine Brandão

FFLCH - Universidade de São Paulo

Assinatura:

Prof ${ }^{a}$. Dr ${ }^{\mathrm{a}}$. Norma Seltzer Goldestein FFLCH - Universidade de São Paulo

Assinatura:

Prof. Dr. Émerson de Pietri

FE - Universidade de São Paulo Assinatura:

Profa . Drª Fabiana Cristina Komesu UNESP

Assinatura: 


\section{Para Xico - meu amor e primeiro interlocutor -, pela paciência, companheirismo, pelas palavras de incentivo,}

por minha ausência durante o estágio em Grenoble-França.

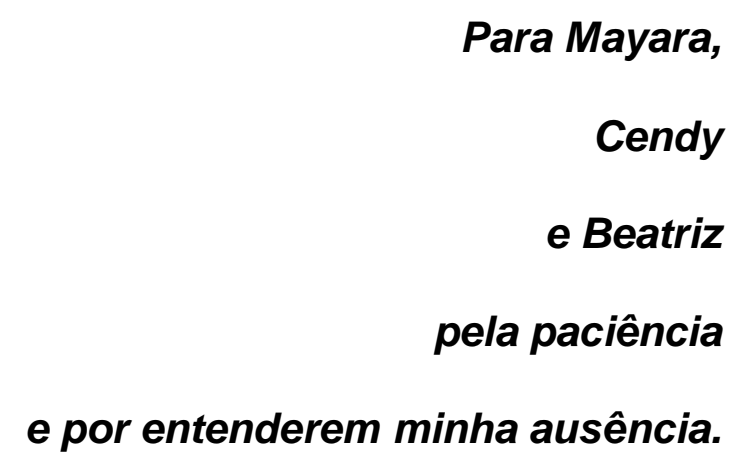

Para Maria de Lourdes - minha segunda mãe -, pelo apoio incondicional. 


\section{AGRADECIMENTOS}

Ao professor Manoel, Mestre e Amigo, um agradecimento especial, pela paciência, pela competência na orientação atenta e crítica e pela partilha de conhecimentos.

Aos professores Helena Hathsue Nagamine Brandão e Émerson de Pietri, pela competência na leitura do trabalho e pelas preciosas sugestões, por ocasião do exame de qualificação.

À professora Fraçoise Boch, da Université Stendhal Grenoble 3, pela coorientação atenciosa, durante o estágio de doutorado-sanduíche no Laboratoire de Linguistique et de Didactique des Langues Étrangères e Maternelles (LIDILEM), em GrenobleFrança.

Aos professores da Université Stendhal Grenoble 3 (França), pela partilha de conhecimentos acadêmicos durante os cursos e pelas discussões proveitosas durante minha apresentação no grupo de doutorandos do LIDILEM. Em especial, à professora Fanny Rinck, pelas valiosas sugestões de leitura, por ocasião da leitura do projeto, durante o curso Introduction à Analyse du Discours.

Ao grupo de estudos Práticas de leitura e escrita em português língua materna, pelos momentos de estudos.

À CAPES, pela bolsa de estudos concedida para o período de estágio doutoradosanduíche, no LIDILEM, Grenoble-França.

À FUVEST, pela cessão do material analisado.

À minha família, especialmente à Maria de Lourdes Esvael e a meus irmãos Enilson e Elda, que não mediram esforços ao apoiar-me; às minhas filhas, por minha ausência e, sobretudo, a meu marido, pelo apoio inigualável.

À Mayara e ao Enilson, pela tradução do resumo para o inglês.

Ao Paulo Alexandre, pela amizade, pelas palavras de incentivo e pela revisão do trabalho.

Ao Felipe e família, pelos momentos de carinho e de cuidado com minhas filhas.

À Jayne, Elenice, e Amarylis, pelo convívio prestimoso durante as construções das nossas formações; à Lourdinha, também pelo companheirismo nas aulas de francês; à Vera, Sabrina, Tânia e demais amigos da Diretoria Regional de Educação - DRE Penha, pela amizade e pelo apoio. À Eliane Seraphim, que conduziu meu afastamento do trabalho junto ao secretário da educação da prefeitura de SP, para 
cumprir estágio na França. E, em especial, à Cida Serapião pelas palavras de encorajamento, pelo apoio absoluto e por compartilhar seus profundos conhecimentos na área da educação.

Ao Luiz André, pelo convívio durante o estágio na França, pelas conversas nas horas de incertezas e pelas trocas acadêmicas.

Aos que me acolheram por ocasião do estágio de doutorado-sanduíche, na França, pelo carinho e preocupações dispensadas: Khamphiou e kim, pelo companheirismo doutoral; Elisabeth, pelos "papos legais" sobre a cultura francesa; Adriana, pelos momentos de alegria, quando a saudade batia. Em especial à Cinira e Nicolas, pela amizade construída e por me abrigarem em um dos momentos mais difíceis durante o estágio na França.

À Nádia e Paulinho Vasconcelos e suas filhas, primos queridos, que me hospedaram ao término do estágio na França, com muito carinho e motivações, para que pudesse participar do II SIMELP, em Portugal.

À Paróquia da SS.Trindade (IEAB), na pessoa do reverendo Arthur Cavalcanti, pelo apoio e carinho.

Aos amigos da EMEF Carlos Chagas, pelo carinho e pela motivação. À Cléo, especialmente, pela competência na condução da prorrogação do meu afastamento junto à prefeitura, sem a qual não poderia participar do II SIMELP, em Portugal.

Aos queridos amigos Lelena, Nair, Pedro, Clarice e Sidney, Morais, Isa, Orlando, Rute, Dermi, Cecília Stringhini e família, pelas diferentes maneiras de apoio; e a todos aqueles que, direta ou indiretamente, contribuíram para a realização deste trabalho. 


\section{RESUMO}

ESVAEL, Eliana Vasconcelos da Silva. A construção do ponto de vista dominante na escrita de pré-universitários. Tese (doutorado em Letras). Faculdade de Filosofia, Letras e Ciências Humanas - Universidade de São Paulo, 2011.

Esta pesquisa tem por objetivo investigar um aspecto particular na produção escrita de estudantes pré-universitários, a saber: a construção de pontos de vista e, especificamente, do ponto de vista dominante, em 270 redações do exame vestibular da FUVEST/2006. Como fundamentação teórica, tomo as redações de vestibular sob duas perspectivas: 1) a enunciativa, a fim de identificar os pontos de vista presentes no texto por meio da hierarquização dos diferentes enunciadores; e 2) a discursiva, que permite observar como os diferentes saberes, mobilizados pelo escrevente, intervêm nas ligações e nas fissuras argumentativas do texto para construir pontos de vista e, especificamente, o ponto de vista dominante. Por meio dessa abordagem, enunciativo-discursiva, identifico os posicionamentos enunciativos do escrevente e seus desdobramentos discursivos. A análise das redações - que envolve a organização argumentativa interna ao texto e sua relação com os tipos de saberes mobilizados em sua construção - exige dois procedimentos articulados: um olhar para redação de vestibular como gênero, acatando sua constituição heterogênea e suas regularidades na organização argumentativa do texto; outro olhar, para descrever os desdobramentos discursivos dessa organização, buscando nos modos de qualificação as representações dos posicionamentos do escrevente. Os resultados revelaram que o exame vestibular, concebido como um evento de letramento, comprova as relações dialógicas determinadas por uma situação de produção que é regulada socialmente. O escrevente, fruto da interação social, se apoia discursivamente nos saberes escolares e extraescolares por ele mobilizados e elege os elementos qualificadores como importante estratégia argumentativa na construção de pontos de vista e, primordialmente, na construção do ponto de vista dominante. A construção do ponto de vista dominante se estabelece a partir do diálogo com outros pontos de vista. O diálogo com os textos da coletânea do exame foi preponderante nessa construção e - recurso à mobilização de saberes de esferas diferentes das da coletânea fortaleceu o efeito polifônico da construção do ponto de vista dominante, mostrando que ela é resultado do modo como o escrevente lê e interpreta esses textos; moldado por suas práticas letradas - escolares e extraescolares - e regulado por suas representações. Esses fatos comprovam a importância do ensino e da aprendizagem da linguagem escrita por meio de um gênero, considerando seus aspectos enunciativos e discursivos.

Palavras-chave: escrita, redação de vestibular, estratégias argumentativas, mobilização de saberes; construção de pontos de vista. 


\begin{abstract}
ESVAEL, Eliana Vasconcelos da Silva. The construction of the dominante point of view in the writhing of pre-college. Thesis (doctoral in Letras). Faculdade de Filosofia, Letras e Ciências Humanas - Universidade de São Paulo, 2011.

This research has for objective to investigate a particular aspect in the written production of students who are going to take the exame for college entrance: the construction of points of view and, specifically, of the dominant point of view in 270 vestibular'essays of FUVEST of the college entrance exam/2006. As a theoretical basis, I take the college entrance exam essays from two perspectives: 1) the enunciative, to identify the points of view in the text through the hierarchy of different enunciators, 2) the discursive, which will observe how the different knowledge, mobilized of different spheres of activities, intervine in the linkings involved in the fissures of the argumentative text to build points of views and, specifically, the dominant point of view. The analysis of the essays, which involves the internal organization of argument to the text and its relation to the types of knowledge mobilized in its construction, articulated requires two procedures: a look at writing as a genre, respecting its constitution and its heterogeneous regularities, and observing primarily the presence of qualifying elements, as argumentative strategy, another look, to describe the consequences of this discursive organization, looking at ways of qualifying the representations of the positions of the subject. The results revealed that the exame for college entrance, designed as a literacy event, proves the dialogical relations determined by a production situation that is socially regulated. The subject supports discursively on the school knowledge and extra-school knowledge mobilized by him and chooses the qualifying elements as important argumentative strategy in the construction of points of view and primarily in the construction of the dominant point of view. The dialogue with the texts supplied for the exame was predominant in this construction, showing that it is the result of how the subject reads and interprets these texts. It is shaped by their writing practices of which the students participated during his life as a subject and it is regulated by representations. These facts demonstrate the importance of teaching and learning of written language through a genre, considering its enunciative and discursive aspects.
\end{abstract}

keywords: writing, vestibularessays, argumentative strategies, mobilization of knowledge, construction of points of view. 


\section{LISTA DE TABELAS}

Tabela 1 Quantidade de parágrafos nas redações..................................... 53

Tabela 2 Ordem de apresentação dos textos na coletânea e estruturação do texto do vestibulando............................................................ 202

Tabela 3 A ordem dos textos da coletânea e o diálogo com os

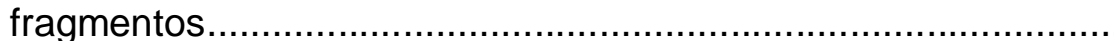

204

Tabela 4 Comparativo entre a estruturação das redações e tipos de ensino/frequência a cursinho preparatório

Tabela 5 Comparativo entre a estruturação das redações e a frequência a curso preparatório.

Tabela 6 Comparativo das esferas mobilizadas pelo escrevente............... 212

Tabela $7 \quad$ Esferas diferentes da coletânea................................................ 213

Tabela 8 Comparativo entre as esferas mobilizadas, tipo de ensino e frequência a cursinho preparatório.............................................. 217

Tabela 9 Comparativo frequência a cursinho em ensino público................. 218

Tabela 10 Comparativo entre as diferentes esferas e a frequência a cursinho preparatório................................................................... 219

Tabela 11 Panorama dos PDVs................................................................ 222

Tabela 12 Comparativo ente os PDVs e tipo de ensino/frequência a cursinho

\section{LISTA DE QUADROS}

Quadro 1 Autores / Tipos de texto....................................................... 57

Quadro 2 Comparativo entre a coletânea e uma redação (Exemplo 2)....... 118

Quadro 3 comparação entre o segundo fragmento e uma redação.............. 128 


\section{SUMÁRIO}

Introdução

Capítulo 1: Tema, literatura sobre o tema e seleção de conceitos teóricos... 18

1.1 Tema da pesquisa e material analisado.................................... 18

A. Circunscrição do tema da pesquisa: a Redação de 18 Vestibular......

B. A proposta de redação da FUVEST/2006: a constituição do 25 corpus e do objeto de análise.

1.2 Noções de letramento e de escrita como prática social............... 32

1.3 Concepção de linguagem...................................................... 39

1.4 A redação de vestibular como gênero discursivo......................... 43

A. A redação de vestibular é um gênero? 43

B. Objetivos e função social da redação de vestibular 48

1.5 A redação de vestibular e sua dimensão textual e enunciativo- 50 discursiva

1.6 A dimensão textual........................................................... 52

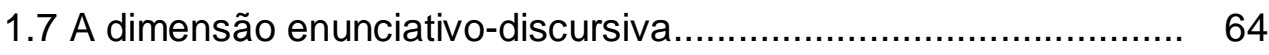

A. Enunciado e enunciação....................................................... 64

B. A historicidade do gênero................................................. 66

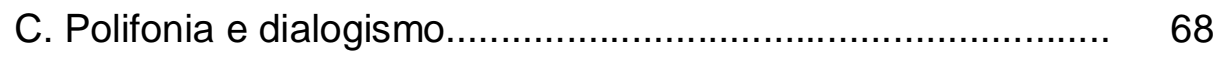

D. Discurso e interdiscurso .................................................... 71

E. Memória discursiva........................................................... 74

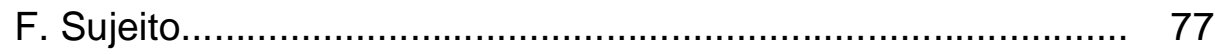

Capítulo 2: Incursões teórico-metodológicas sobre "ponto de vista"........... 80

2.1 A construção de PDVs........................................................... 80

2.2 Sobre a noção de ponto de vista.............................................. 80

2.3 A qualificação como estratégia argumentativa na construção de PDVs.

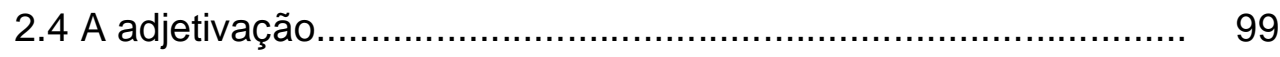

2.5 A modalização................................................................. 102

2.6 A construção de pontos de vista: enxergando as vozes............... 105

A. O PDV da coletânea........................................................ 110 
B. O PDV buscado fora da coletânea........................................... 110

C. O PDV do destinatário........................................................ 110

D. O PDV dominante.............................................................. 111

Capítulo 3 A construção do PDVD e a relação dos textos dos 114 vestibulandos com a coletânea e com a instrução.

3.1 A ordem dos textos da coletânea e a estruturação do texto fragmento como o privilegiado

3.3. A ordem dos textos da coletânea e a escolha do segundo 126 fragmento como o privilegiado.

3.4 A ordem dos textos da coletânea e a escolha do terceiro fragmento como o privilegiado

3.5 A ordem dos textos da coletânea e a escolha da instrução como a privilegiada.

Capítulo 4 Construção do PDVD e representações sociais

4.1 A construção do PDVD e a representação social do trabalho

A. A representação social do trabalho aplicada ao primeiro fragmento

B. A representação social do trabalho aplicada ao segundo fragmento

C. A representação social do trabalho aplicada ao terceiro fragmento

4.2 A construção do PDVD e a representação do escrevente sobre a universidade.

4.3 A construção do PDVD e sua relação com saberes provenientes de outras esferas.

A. Os saberes projetados pela enunciação no enunciado. 167

B. Os saberes e a esfera literária 171

C. Os saberes e a esfera popular. 175

D. Os saberes e a esfera religiosa 187

E. Os saberes e a esfera midiática.

F. Os saberes e a esfera histórica.

G. Os saberes e a esfera do mercado cultural. 198

H. Os saberes e a esfera da saúde 198 
5.1 Classificação e interpretação dos resultados relacionados à $\quad 201$ ordem dos textos da coletânea.

5.2 Classificação e interpretação dos resultados relacionados às 209 representações sociais.

5.3 Relação dialógica entre a construção do PDVD e os PDVs depreendidos pelo escrevente...

5.4. A construção do PDVD na redação de vestibular. 225

Considerações Finais 


\section{Introdução}

O modo de se conceber o ensino de língua materna é pivô de muitas discussões, haja vista o baixo desempenho dos alunos evidenciado em avaliações externas à escola, como o ENEM (Exame Nacional do Ensino Médio) ou a Prova Brasil. O mesmo se pode dizer sobre o ensino da produção textual. Nos últimos anos, muito se tem discutido sobre a produção textual e o ensino dos gêneros do discurso na escola. Em curso de formação ministrado ${ }^{1}$ aos coordenadores pedagógicos e professores da rede municipal de São Paulo, ouvi que os professores das diferentes áreas, mesmo solicitando aos alunos a leitura de textos que os levem a expressar opiniões e críticas, não sabem como os ensinar a escrever um texto argumentativo. Apesar da crescente oferta de cursos de formação continuada voltada para o ensino da produção textual, em geral, na perspectiva sociointeracionista, a maioria dos professores de Língua Portuguesa participante de tal formação ainda não domina conceitos básicos dessa perspectiva. Desse modo, a dificuldade em lidar com o processo de ensino e de aprendizagem da leitura e da escrita, em particular, com o ensino de textos argumentativos, presente no dia a dia da escola e da sala de aula, se alia à dificuldade em dominar (quanto mais de dominar criticamente) abordagens teóricas sempre novas para os professores.

Esta pesquisa, ao investigar modos de construção do ponto de vista dominante em textos escritos, pretende contribuir para a mudança desse quadro, em particular para o enfrentamento de questões discursivas registradas em aspectos linguísticos muito utilizados, mas nem sempre muito bem compreendidos, como a adjetivação e a modalização.

A pesquisa insere-se nos estudos da produção textual concebida como processo. O estudo do processo de produção textual assumiu papel importante em pesquisas da Linguística Aplicada, a partir do momento em que a escrita passou a ser vista como prática social. Como parte da prática avaliativa, o exame de redação realizado por ocasião do vestibular é, também, apesar de sua circulação restrita se considerado o todo da sociedade, uma prática social. Ponderando sobre o conjunto

\footnotetext{
${ }^{1}$ Fiz parte da equipe de formação continuada da Secretaria Municipal de Educação de São Paulo de jan/2006 a set/2008. Os cursos foram ministrados junto à Diretoria Regional de Educação Penha, por ocasião da implementação do programa "Ler e escrever, em todas as áreas do conhecimento".
} 
de práticas sociais que cercam a produção da redação no vestibular, senti necessidade de compreender o processo de produção da escrita nessa situação de avaliação e particularizei o estudo para o vestibular da FUVEST ${ }^{2}-2006$.

O vestibular é um evento singular da instituição escolar, uma vez que marca um episódio importante na vida do estudante: o acesso ao ensino superior. Em se tratando de vestibular da FUVEST, é ainda mais marcado porque regula o acesso a uma universidade pública, representante das instituições educacionais de boa qualidade no país. A prova de redação, parte importante do vestibular é, muitas vezes, um temor para o vestibulando. Nesse contexto, seja nas escolas de ensino médio, seja nos cursinhos preparatórios para o vestibular ou mesmo em materiais publicados em apostilas ou na internet, têm sido oferecidos aos futuros candidatos diferentes recursos para o aperfeiçoamento de sua escrita.

Apesar dessa gama de ofertas, os alunos ainda encontram dificuldades ao redigir um texto. Buscam nesses materiais modelos e recursos que possam the servir de instrumentos e guiá-los na condução de uma boa escrita. O que parece não estar funcionando no ensino da produção textual é o recurso unicamente ao treino de estruturas ou reprodução de modelos para se chegar a uma boa escrita. Nesse sentido, como já apontaram vários outros estudos em diferentes contextos, há vacância de um trabalho voltado para o desenvolvimento da discursividade nas produções textuais dos alunos. Tomar o ensino da escrita nessa perspectiva é conceber a produção textual como constitutivamente dialógica, instituída como prática social. E tomá-la como prática social é considerar o processo de escrita inserido no processo sócio-histórico, não, porém, apenas como um jargão, mas buscando recuperar esses processos por meio do diálogo entre as práticas sociais, a língua e o texto, recuperação que se torna possível quando a construção discursiva do texto é tomada como objeto.

No interior dessa problemática, esta investigação se interessa pela construção do ponto de vista dominante em textos escritos e por modos de sua organização, considerados o tema, o tipo de exame (para ingresso à universidade) e a situação de avaliação. Particularizando tal olhar, preocupa-se com as relações do escrevente com a sua escrita, melhor ainda, com as suas representações da escrita,

\footnotetext{
${ }^{2}$ Fundação Universitária para o Vestibular: entidade responsável pela elaboração e correção do exame vestibular da Universidade de São Paulo - USP, à qual agradeço pela cessão do material.
} 
bem como com as determinações de condições de produção estritas como as do exame vestibular da FUVEST, tudo isso buscado em relações linguisticamente registradas nos textos dos candidatos. Trata-se de analisar 0 trabalho do escrevente $^{3}$ com o seu texto e com as imagens que ele faz da escrita, de seu interlocutor e de seu objeto de discurso.

O trabalho se apoia, do ponto de vista teórico, em estudos da teoria enunciativa da linguagem, sobretudo, em Bakhtin (1992; 1986, e outros) e na semântica da enunciação, sobretudo, em Ducrot (1987). A expectativa é associar essas perspectivas à de outros teóricos que trabalham com o estudo da construção do ponto de vista dominante na organização do texto como, por exemplo, Rabatel (1997, 1998, 2000, 2004 e outros). Ao mesmo tempo, busca identificar as diferentes representações dos escreventes sobre a escrita, sobre o objeto de discurso, sobre o interlocutor - a universidade - e sobre si mesmos, em função das estratégias argumentativas por eles adotadas. Ou seja, com o estudo do texto dissertativoargumentativo escrito, partindo das fronteiras, sobretudo, da estrutura composicional e do conteúdo temático do gênero, busco determinar como a organização argumentativa se relaciona com aspectos enunciativo-discursivos na construção do ponto de vista dominante. Ao mesmo tempo e na mesma proporção, busca apoio em teorias do texto e do discurso, tais como Amossy (2005a, 2005b, 2006, e outros), Maingueneau (1993, 2002, 2004, 2005, 2008 e outros), Pêcheux (1997, 1999, 2002), Fiorin (1999), Possenti (2001) e Koch (1998, 1999).

Se, por um lado, da perspectiva enunciativa, pretendo identificar os pontos de vista (doravante PDVs) presentes no texto por meio da hierarquização de diferentes enunciadores e, a partir dela, estratégias adotadas pelos escreventes para garantir uma direção argumentativa para o texto; por outro, a perspectiva discursiva permitirá observar como os diferentes saberes, provenientes de formações discursivas determinadas, intervêm nas ligações e nas fissuras argumentativas do texto. Assim, a análise do processo de construção do ponto de vista dominante (doravante PDVD) na organização do texto, foco central da pesquisa, é fundamentada no diálogo possível entre diferentes perspectivas teóricas.

\footnotetext{
${ }^{3}$ Filio-me, aqui, às reflexões de Possenti (2001) que, baseado em Granger, define o trabalho do escrevente como suas escolhas. Para o autor, a linguagem é "resultado do trabalho de seus construtores/usuários", (p. 228), o trabalho de escolha de um enunciado e não de outro. Nesse sentido, define-se linguagem como ação, ação do sujeito sobre/na linguagem. Este tema será detalhado em item próprio.
} 
Como objetivo específico, busco

- compreender e descrever as estratégias utilizadas pelos candidatos no processo de construção do PDVD, a fim de explicitar o modo como organizaram o texto para defender um posicionamento diante do tema "o trabalho";

- descrever o modo pelo qual o candidato articula essas estratégias com diferentes fontes de saber ao construir o PDVD na organização do texto;

- descrever de que modo as estratégias argumentativas utilizadas pelo escrevente se articulam com a modalização e, sobretudo, com a qualificação.

A hipótese inicial que orienta a pesquisa é a de que, por meio do uso dos diferentes modos de qualificar, o escrevente sustenta a sua posição diante do tema "o trabalho", utilizando-os como uma das estratégias para a construção do PDVD na organização do texto. Por sua vez, essa construção será observada segundo dois aspectos: (a) o da leitura que o escrevente faz da coletânea fornecida pela prova e, mediado por ela, o aproveitamento dos fatos históricos nela referidos ou a partir dela inferidos e (b) o modo como o escrevente sustenta esse julgamento, a fim de marcar efetivamente seu posicionamento. Elegi esses dois pontos como os lugares privilegiados de observação que orientarão o olhar do analista para a construção do PDVD no texto. A partir desse ponto de observação, pretende-se, também, refletir sobre as possibilidades do ensino-aprendizagem da escrita, especificamente de textos dissertativo-argumentativos.

O trabalho está organizado em cinco capítulos. No capítulo 1, apresento o tema e a seleção de conceitos teóricos. No capítulo 2, busco fundamentação teóricometodológica para a noção de "ponto de vista". Nos capítulos 3 e 4, desenvolvo a análise, abordando: no capítulo 3 , a construção do PDVD e a relação dos textos dos vestibulandos com a coletânea e com a instrução, fornecidas pela prova; e, no capítulo 4 , a relação entre a construção do PDVD e as representações sociais. $O$ capítulo 5 é composto pela recolha e interpretação dos resultados e, encerrando o trabalho, apresento as considerações finais e as referências bibliográficas. 


\section{CAPÍTULO 1}

\section{TEMA, LITERATURA SOBRE O TEMA E SELEÇÃO DE CONCEITOS TEÓRICOS}

Neste capítulo, apresento o tema da pesquisa, faço breve revisão da literatura a respeito dele e busco dar os primeiros contornos teóricos, a partir da seleção de conceitos advindos das teorias da enunciação e da análise do discurso.

\subsection{Tema da pesquisa e material analisado}

Nesta primeira parte, sem a pretensão de exaustividade, mas apenas como um primeiro passo na circunscrição do tema da pesquisa, apresento algumas considerações sobre a instituição da redação como instrumento de avaliação e sobre estudos que têm sido feitos a respeito da escrita dos vestibulandos (item $A$, abaixo). Descrevo, ainda, a proposta de redação da FUVEST-2006, que gerou o corpus para análise, e exponho a constituição do corpus e do objeto de análise (item B). Finalmente, redação de vestibular como objeto de análise.

\section{A. Circunscrição do tema da pesquisa: a redação de vestibular}

O vestibular da FUVEST tem se caracterizado por solicitar dos candidatos a produção de um texto dissertativo. No Brasil, como em outros lugares, por exemplo, na França, a dissertação está presente em práticas de escrita há muito tempo. De acordo com Viala (1990), os primeiros registros da dissertação entre os franceses constam do século XVII. No início ela era ligada à crítica literária e não ao ensino. No decorrer dos anos, o uso da dissertação passou a integrar avaliações escritas efetivando-se também como exercício escolar. Atualmente, ela é utilizada também nos exames de acesso às Universidades francesas - o baccalauréat ${ }^{4}-$ em que 0 estudante deve dissertar sobre algum tema literário, podendo ser um romance ou um texto teatral, por exemplo.

\footnotetext{
${ }^{4}$ Exame nacional na França realizado ao término do Lycée (equivalente ao Ensino Médio no Brasil) e que possibilita ao estudante o acesso à universidade.
} 
No Brasil, a dissertação possui características um pouco diferentes, principalmente em sua extensão. É considerada um instrumento de avaliação para medir a competência em escrita dos candidatos ao ensino superior. Pensando nesse papel da dissertação, mas, também, na própria utilização da redação como instrumento de avaliação (outras instituições elegem outros tipos dominantes de texto), julguei pertinente traçar um breve percurso da presença da redação nos exames vestibulares, desde sua implantação até os dias atuais. Para tanto, utilizome, basicamente, dos trabalhos de Samara (2007), da legislação sobre o tema e de trabalhos acadêmicos diretamente relacionados ao estudo da redação de vestibular.

A instituição de um exame para selecionar candidatos ao ensino superior remonta, no Brasil, ao ano de 1808. O nome vestibular é estabelecido em 1915, pelo decreto $\mathrm{n}^{\circ}$ 11.530, mas desde 1911 já era utilizado. A prova era oral e escrita, composta por "questões dissertativas longas" (SAMARA, 2007, p. 26). Só a partir da década de 1950 surgiram os vestibulares com questões de múltipla escolha, sendo o curso de medicina da USP o primeiro a adotar tal sistema. A prova de redação, não obrigatória, estava presente em alguns exames. Cada faculdade se responsabilizava pela elaboração de seu vestibular, por isso, os exames tinham concepções diferentes. Na década de 1960, "O sistema escolar brasileiro teve que aprimorar seu rendimento quantitativo, tomando uma série de medidas que culminariam, mais tarde, com um aumento da oferta de vagas perante a demanda social crescente." (Op. Cit., p. 34). A necessidade, então, de dar conta dessa demanda - número crescente de vestibulandos e candidatos excedentes - e a conjuntura social da época (início da ditadura militar), que impôs maior controle sobre universidades e estudantes, levaram a outro modo de organização dos exames vestibulares: em agrupamentos, as faculdades fundaram instituições responsáveis pela elaboração do exame vestibular (Cescem, Cescea e Mapofei $)^{5}$, mas de modo ainda informal.

A Universidade de São Paulo (USP) com a intenção de unificar seu vestibular, cria, em 1976, a Fundação Universitária para o Vestibular (FUVEST) que, a partir de 1977, elabora o exame vestibular de três instituições públicas: Universidade de São Paulo (USP), Universidade Estadual Paulista (UNESP) e Universidade Estadual de Campinas (UNICAMP) e, a partir de 1978, também de instituições particulares. Mais

\footnotetext{
${ }^{5}$ CESCEM: Centro de seleção de candidatos às Escolas Médicas. CESCEA: Centro de seleção de candidatos às Escolas de Administração. MAPOFEl: Vestibulares unificados de Ciências Exatas e Engenharia: Mauá, Poli e FEl.
} 
tarde, UNESP e UNICAMP passam a realizar o exame vestibular separadamente: a UNESP em 1981 e a UNICAMP em 1982.

Apesar de a redação ter sido obrigatória nos exames vestibulares a partir do decreto 79.298 de 24/02/77, a discussão sobre essa prática está presente desde a década de 1960, por ocasião das discussões sobre a (in)eficiência dos exames vestibulares na seleção de candidatos bem preparados para ingressar no ensino superior. Essa discussão acirrou-se na década de 1970 com a inclusão, não sem polêmica, da redação nesses exames (cf. GATTI, 1992), bem como de outras mudanças no âmbito da Educação. Como exemplo, no que se refere ao ensino de língua, pode-se considerar a década de 1970 como um período que mexeu com sua estrutura na escola, por meio, principalmente, da Lei $n^{0} 5692 / 71^{6}$, a Lei de Diretrizes e Bases (LDB), que estabeleceu a separação do ensino de Língua Portuguesa em três eixos: gramática, estudos literários e redação, estrutura presente até hoje, em algumas instituições de ensino.

A justificativa para a inclusão da redação nos exames vestibulares foi baseada na constatação do uso ineficaz e inadequado do português escrito. Apontava-se, na época (década de 1970), a crise no ensino da língua materna:

Tal determinação [obrigatoriedade da redação no exame vestibular] representa, de certa maneira, uma resposta às discussões que há já alguns anos se vinham desenvolvendo em torno da denúncia amplamente divulgada pelos veículos de comunicação de massa contra o uso incorreto, ineficaz e inadequado do português escrito no Brasil atual. Jornais e revistas apresentaram o problema, acusando de decadente e insatisfatório $o$ ensino e a aprendizagem do português nas escolas brasileiras; o Conselho Federal de Educação e alguns Conselhos Estaduais emitiram pareceres e indicações sobre 0 assunto; intelectuais e educadores apontaram uma grave crise no ensino da língua materna (SOARES, 1978, p. 53).

Ainda segundo Soares, "na busca de causas para tal situação, o vestibular foi frequentemente acusado" (op. cit.). A acusação era justificada pelo fato de a maioria dos exames vestibulares utilizarem unicamente questões de múltipla escolha para selecionar candidatos ao ensino superior. Essa justificativa indignou os educadores da época, uma vez que, na verdade, a complexidade do problema do ensino de língua materna solicitava uma avaliação muito mais analítica do que a produzida por provas de múltipla escolha.

\footnotetext{
${ }^{6}$ Revogada pela Lei oㅜ 9394, de 20 de dezembro de 1996.
} 
A instituição da redação como parte obrigatória da prova de Língua Portuguesa do exame vestibular contribuiu para que os olhares se voltassem para o ensino da redação na escola, como um efeito retroativo. A partir da década de 1970, o número de oferta de livros didáticos que contemplavam, mesmo que relegado à última parte do capítulo, o ensino da redação aumentou consideravelmente, bem como de manuais específicos, conforme afirma Bunzen (2005, p. 64), em seu trabalho sobre análise de livros didáticos:

[...] isso afetou enormemente a produção de livros didáticos para esse nível de ensino: Redação escolar: criatividade, de Samir Meserani (1971); A redação do vestibular, de José Armando Macedo (1975); Arquitetura da Redação, de José Fernando Miranda (1977); Teoria e prática da Redação, de Zoleva Felizardo (1978); Técnicas de Redação - as articulações linguísticas com técnica de pensamento, de Magda Soares e Edson Nascimento Campos (1978); Curso de Redação, de Hildebrando A. de André (1978); Laboratório de Redação, de Gustavo Krause et al 1979), entre outros.

Além dessa inserção nos manuais didáticos, entraram em cena vários estudos elaborados no final da década de 1970, alguns reunidos em cadernos de pesquisas da Fundação Carlos Chagas (números 16, 19, 23, 24 e outros), dentre os quais destaco os números 19 e 23. Ambos investigam o desempenho linguístico dos candidatos no vestibular, sendo que cada autor particulariza um aspecto, por exemplo, a distribuição dos demonstrativos (FERNANDES, 1976), a concordância verbal (CARONE, 1976), estudo do período (PÉCORA, 1977), provas de argumentação (OSAKABE, 1977), utilização do léxico: estudo dos adjetivos (NEGRÃO, 1977) dentre outros.

A partir da década de 1980, os estudos, mais empíricos, se aprofundam e diversificam os aspectos analisados. Nesse sentido, surgem vários trabalhos de dissertação de mestrado e teses que abordam diferentes aspectos da escrita em redações de vestibulares. Dentre eles, destaco alguns pioneiros, que se tornaram referência nos estudos sobre o tema: Rocco (1981), Pécora (1999), Costa Val (2006), Barros (1985). Na década de 1990, os estudos se caracterizam não só por aprofundar aspectos da superfície textual, mas de incluir em suas análises aspectos da concepção de linguagem sociointeracionista, em que se considera não o texto em si mesmo, mas a dialogia que lhe é inerente. As marcas linguísticas são vistas a partir do que constitui a escrita em sua heterogeneidade. Nessa direção, menciono 
alguns: Marques (1997) investiga o trabalho do aluno com as relações intertextuais e a verificação de como a coletânea influencia nessa intertextualidade e no estabelecimento do estilo individual; Chacon (1998) aborda o ritmo da escrita, demonstrando a organização do heterogêneo da linguagem, por meio da análise do uso da pontuação; Corrêa (2004) investiga as marcas linguísticas do imaginário do escrevente sobre a escrita, com o objetivo de definir um modo heterogêneo de constituição da escrita. A partir dos anos 2000, os trabalhos sobre redação de vestibular $^{7}$ crescem enormemente no Brasil, ampliando o leque de abordagens.

As primeiras pesquisas revelam um ensino com função prescritiva, voltado para o treino de estruturas fixas e preenchimento de espaços lacunares, resultando, muitas vezes, num texto incoerente, conforme aponta Pécora em seu estudo sobre redações: esse "preenchimento" não se constitui em sentido pelo leitor, uma vez que "a maioria absoluta das redações [...] pautava a sua reflexão por uma colagem mal ajambrada de frases feitas e acabadas, retiradas de fontes não muito diversificadas" (1999, p.14-5). Nessa mesma direção, outro estudo aponta que nessa concepção de ensino da escrita o resultado não é animador: Rocco (1981) afirma que, em relação à elaboração de texto criativo, por exemplo, apenas quatro em 1500 redações de vestibular analisadas em seu trabalho foram avaliadas como criativas. Segundo a autora, "a linguagem do vestibulando se caracteriza pelo uso excessivo de clichês e frases feitas" (p. 246, grifos da autora). As pesquisas mais recentes, sobre a escrita, mostram que o olhar do pesquisador mudou. $E$ isso se refletiu nos enunciados das provas de redação:

[...] de uns oito anos pra cá, os temas para redação têm se sofisticado, no sentido de esta apresentar vários elementos para os candidatos desenvolverem suas idéias, impedindo assim que muitos sejam levados a criar os chamados "textos pré-fabricados". Este fato seria bastante possível, numa proposta como [...] [a de] 1977: tratarse simplesmente da "solidariedade" era um campo fértil para a plantação de clichês e frases feitas, situação que não ocorre mais (SAMARA, 2007, pp. 64-5).

As concepções de linguagem regradas pela expressão do pensamento e instrumento de comunicação estão sendo, aos poucos, substituídas por uma concepção de linguagem sociointeracionista. O texto tem deixado de ser somente pretexto para o ensino normativo da língua. Entretanto, aquelas concepções de

\footnotetext{
${ }^{7}$ O levantamento é parcial. Além de teses e dissertações, há inúmeros artigos sobre o tema.
} 
língua/linguagem centradas na língua como código e o ensino como prescrição deixaram seus rastros e ainda hoje são reconhecidas em sala de aula. Nas aulas de Língua Portuguesa, apesar da introdução do ensino de gêneros discursivos, a maior porção ainda é a da gramática normativa.

Apesar do avanço nas pesquisas, o modo de gerir os negócios relacionados ao ensino tem deixado muito a desejar. Mais recentemente, o exame de redação voltou à mídia quando a imprensa, em dezembro de 2001, denunciou o caso de um candidato semianalfabeto aprovado no vestibular de uma universidade privada na cidade do Rio de Janeiro. Episódios como esses revelam as mazelas de muitos exames vestibulares, cujas faculdades apresentam, normalmente, mais vagas do que candidatos, porque é o interesse comercial que fala mais alto.

Diante desse acontecimento, o ministro da educação, na época, Paulo Renato Costa Souza, baixou uma portaria (portaria ํㅜ 391/2002 MEC, de 07/02/2002) que reinstituiu a prova de redação nos exames vestibulares, a partir de 2003 , tornando-a tanto obrigatória quanto eliminatória em todos os vestibulares nacionais. Essa portaria também incluiu, na somatória das notas do vestibular, a incorporação da nota (total ou parcial) da prova de redação do ENEM ${ }^{8}$.

Apesar da implantação dessa portaria, os exames vestibulares ainda estampam as manchetes dos noticiários, colocando em jogo sua fidedignidade com fatos como o do menino de apenas oito anos que foi aprovado no exame vestibular, no início de 2008, para o curso de direito da UNIP (Universidade Paulista) de Goiânia. Um exame que exigia a escrita de uma redação. Vê-se que falta, ainda, seriedade em muitos desses exames.

Por outro lado, há universidades em que os exames vestibulares são elaborados com seriedade e em que a redação é parte dos instrumentos de avaliação real da competência escrita do candidato. Servem de exemplo as universidades públicas paulistas e muitas outras espalhadas pelo Brasil, públicas ou não. Essa seriedade é fruto de um percurso histórico de aprimoramento: dos instrumentos de avaliação do vestibular, do modo como são constituídas as bancas examinadoras e de como se dá o processo de correção, bem como dos próprios critérios de correção dos textos. Para ficar com o exemplo que interessa diretamente

\footnotetext{
${ }^{8}$ Exame Nacional do Ensino Médio.
} 
a este trabalho, o da Universidade de São Paulo, retomo a entrevista do professor Roberto Costa, consultor da FUVEST, sobre a correção da redação nessa fundação:

Português sempre foi o caso mais complicado de todos, pois na segunda fase tem dez questões e mais uma redação, que vale metade da prova e gera muitas dificuldades. Cada redação é corrigida por dois professores, e as notas dadas vão de zero a quatro - é mais fácil trabalhar em escala pequena - depois o computador multiplica. Se um corretor, por exemplo, deu dois e outro deu três, a nota é a média; mas se houve uma diferença de mais de um ponto, aí um terceiro corretor entra em ação para definir melhor a nota, pois considera-se que há problema de correção. As redações são avaliadas quanto à gramática e sintaxe, coerência textual e adequação de seu desenvolvimento ao tema dado. Quatro é o que se dá para uma redação perfeita e zero significa que ela fugiu totalmente do tema - o que é imperdoável - ou que traz problemas gravíssimos, e o candidato não consegue expressar suas idéias. Todo ano, curiosamente, há muitos zeros sofisticados: demos esse nome metafórico àquelas redações que até são bem articuladas, mas escapam completamente ao tema dado, como se o candidato não o tivesse lido (apud SAMARA, 2007, p. 160).

A correção da redação no exame da FUVEST, com critérios bem definidos, treinamento dos corretores e todo aparato envolvido no processo de avaliação, mostra que o texto dos candidatos é tratado com bastante seriedade.

Voltando ao campo da pesquisa, além dos trabalhos citados, há, no que se refere à redação de vestibular como objeto de estudo, inúmeros outros trabalhos que a estudam em suas pesquisas. A abordagem não é, no entanto, em sua grande maioria, baseada na teoria dos gêneros do discurso, isto é, os aspectos textuais, ainda vistos como desvinculados dos gêneros do discurso, têm sido privilegiados. A meu ver, não considerar o gênero como porta de entrada para os estudos de redações de vestibular é expropriar-se de seu caráter institucionalizado e ficcional, como mostrarei adiante. Destaco, como exemplo de aproveitamento da teoria dos gêneros do discurso associada à teoria do letramento, a pesquisa de Silva (2009). A autora toma como objeto de análise os diferentes gêneros presentes na prova de redação, isto é, o foco do estudo é o gênero e suas características. A pesquisadora chega a conclusões bastante interessantes no que se refere à relação entre a produção eficiente de um gênero e os diferentes letramentos dos escreventes. Nessa relação, a autora destaca o estabelecimento do jogo enunciativo entre escrevente/banca corretora e escrevente/destinatário do gênero em função da proposta da prova de redação. Ela verificou que os letramentos dos escreventes são 
determinantes na produção eficiente de um gênero discursivo, atendendo aos elementos que o definem como gênero, isto é, conteúdo temático, estrutura composicional e estilo, além do estabelecimento do jogo enunciativo, já que na proposta da prova de redação, diferentes gêneros e contextos de produção (com predefinição dos interlocutores e de seus papéis sociais) são disponibilizados para a escolha do candidato. A pesquisadora também trata da influência determinante na proficiência do escrevente, quando os diferencia segundo o letramento escolar e os multiletramentos a que estão expostos no decorrer de sua vida. Ela conclui que a mobilização de diferentes práticas letradas, seja na escola ou em outra esfera de atividade, é bastante favorável ao bom desempenho do escrevente, em detrimento daquele restrito a uma única prática escolar: a redação escolar, como treinamento para a prova de redação. Eis, portanto, um exemplo de pesquisa que, levando em conta a teoria dos gêneros do discurso e as teorias do letramento, é, ao mesmo tempo, interessante e consistente na abordagem das redações de vestibular.

Tendo em vista esse panorama da instituição da redação como instrumento de avaliação dos vestibulandos e considerada, também, a breve referência às diferentes perspectivas que tratam da escrita no vestibular, passo a descrever 0 corpus de que me ocuparei e do objeto de análise que eu própria procurei construir nesta pesquisa.

\section{B. A proposta de redação da FUVEST/2006: a constituição do corpus e do objeto de análise}

A prova de redação da FUVEST é exigida na segunda fase do exame vestibular e é obrigatória para todos os candidatos, fato que revela a valorização da expressão escrita, cujo domínio aumentará a possibilidade de ingresso à universidade.

Como adiantamos, a redação de vestibular do tipo dissertativo-argumentativo é um tipo de texto comumente solicitado em exames vestibulares. Isto se justifica pelo fato de ele exigir que o candidato expresse sua opinião a partir da exposição (dissertação) de um determinado tema. É comum, nas provas de redação da FUVEST, a apresentação, ao candidato, de uma coletânea de textos (verbais ou não), para que ele a tenha como ponto de partida para firmar posicionamentos diante das opiniões nela expressas. $O$ uso de coletânea tem por objetivo oferecer 
informações a respeito do tema dado, ao mesmo tempo em que pode facilitar o início de um debate, uma vez que, normalmente, ela é composta por textos com perspectivas diferentes sobre o tema dado.

No que se refere à correção, segundo o Manual FUVEST/2006:

"[a prova de português] valerá 40 ou 80 pontos, dependendo da carreira. A redação corresponde à metade da prova." (FUVEST, 2006, p. 30).

Na correção da redação levam-se em consideração três aspectos: a) tema e desenvolvimento, b) estrutura e c) expressão (cf. FUVEST, 2006, p. 42). Quanto ao primeiro aspecto, verifica-se se o candidato disserta sobre o tema proposto, bem como se se utiliza da dissertação em prosa ${ }^{9}$. Esses aspectos, se não seguidos pelo candidato, resultarão na não correção da redação, sendo-lhe atribuída nota zero. Com relação ao desenvolvimento, espera-se que o candidato demonstre em seu texto capacidade crítico-argumentativa, maturidade, bem como inventividade. No que se refere ao segundo aspecto, estrutura, avalia-se a capacidade do escrevente em relacionar os argumentos e organizá-los coerentemente, a fim de demonstrar autoria na construção do texto. Quanto à expressão, verifica-se o domínio da norma culta e a fluência do discurso, a exposição clara e precisa dos argumentos. Como se vê, os critérios de correção são bem definidos, explicitados e divulgados no Manual do Candidato.

Ao observar mais atentamente esses critérios, vê-se que eles podem também servir de pontos observáveis para a investigação do modo como o escrevente conduz o processo de construção do PDV que organiza o texto, se se considerar que, no âmbito desta liberdade vigiada, o escrevente deve demonstrar que sabe posicionar-se e expressar-se diante do tema dado, articulando sua posição com as dos fragmentos da coletânea e recuperando esses elementos na estrutura composicional do que chamo gênero redação de vestibular.

Pode-se, assim, concluir que, por trás dos critérios de correção da redação, estão presentes elementos - tema, estrutura e expressão - que remetem para a configuração da redação de vestibular concebida como gênero discursivo, segundo Bakhtin (1992). Vale destacar nesses critérios que, além de se considerarem os elementos formais do gênero, como, por exemplo, a obrigatoriedade do próprio

\footnotetext{
${ }^{9} \mathrm{O}$ manual do candidato considera a dissertação em prosa um gênero.
} 
gênero, a adequação gramatical - aspectos formais mais restritivos -, avalia-se também sua historicidade, uma vez que é apreciada a capacidade do escrevente "para escolher e usar expressivamente o vocabulário". O candidato pode, assim, se utilizar do aspecto formal/objetivo sem deixar de expor seu posicionamento pessoal/subjetivo.

A prova de redação que deu origem ao corpus da pesquisa foi a do vestibular FUVEST/2006. A seleção das redações foi feita de modo aleatório pela própria FUVEST, dentre os candidatos ao curso de Letras. O corpus totaliza um conjunto de 270 textos, dentre os quais 235 foram produzidos por alunos provenientes do estado de São Paulo (capital: 100 redações; interior: 100 redações; e litoral: 35 redações) e 35 foram produzidos por alunos de outros estados do Brasil. O material cedido inclui informações sobre a formação escolar, a situação socioeconômica e familiar, o sexo, a idade e a cidade/estado de cada candidato, obtidas por meio de questionário composto de 29 itens, respondidos por eles no momento da inscrição ao exame vestibular. Além dessas informações, há também a indicação da convocação (ou não) para a matrícula, bem como a pontuação final de cada um dos vestibulandos. Vale registrar que a nota da redação não foi cedida pela FUVEST, nem a autorização para publicação integral das redações.

O exame de Língua Portuguesa da segunda fase do vestibular da FUVEST é composto por uma proposta (única) de redação e por dez questões discursivas. $\mathrm{O}$ candidato dispõe de quatro horas para a realização da prova de Língua Portuguesa, redação inclusa. O tempo demarcado e o suporte limitador de espaço - folha tamanho A4, composta de trinta e quatro linhas - são coerções da situação de enunciação e impõem limitações ao escrevente. O mesmo vale para o tema, que restringe a divagação e obriga o escrevente a manter-se num campo temático mais restrito.

A prova de redação ${ }^{10}$ lança ao escrevente o tema "o trabalho", presente em uma coletânea composta de três fragmentos, reproduzida a seguir:

Texto 1:

\footnotetext{
${ }^{10}$ Disponível no site da FUVEST: <http://www.fuvest.br/vest2006/provas/2fase/por/por06.stm> acesso em fevereiro 2007; cf. anexo I.
} 
O trabalho não é uma essência atemporal do homem. Ele é uma invenção histórica e, como tal, pode ser transformado e mesmo desaparecer.

Adaptado de A. Simões.

Texto 2:

Há algumas décadas, pensava-se que o progresso técnico e o aumento da capacidade de produção permitiriam que o trabalho ficasse razoavelmente fora de moda e a humanidade tivesse mais tempo para si mesma. Na verdade, o que se passa hoje é que uma parte da humanidade está se matando de tanto trabalhar, enquanto a outra parte está morrendo por falta de emprego.

M.A. Marques.

Texto 3:

O trabalho de arte é um processo. Resulta de uma vida. Em 1501, Michelangelo retorna de viagem a Florença e concentra seu trabalho artístico em um grande bloco de mármore abandonado. Quatro anos mais tarde fica pronta a escultura "David".

Adaptado de site da Internet.

O terceiro texto está acompanhado da imagem da escultura "David" criada por Michelangelo. Em seguida, é apresentada a proposta para a elaboração da redação:

INSTRUÇÃO: Os três textos acima apresentam diferentes visões de trabalho. O primeiro procura conceituar essa atividade e prever seu futuro. O segundo trata de suas condições no mundo contemporâneo e o último, ilustrado pela famosa escultura de Michelangelo, refere-se ao trabalho de artista. Relacione esses três textos e com base na idéias neles contidas, além de outras que julgue relevantes, redija uma DISSERTAÇÃO EM PROSA, argumentando sobre o que leu acima e também sobre os outros pontos que você tenha considerado pertinentes (grifos do autor).

O escrevente deve, antes de elaborar a redação, compreender a proposição dos textos da coletânea, já que lhe é solicitada a relação entre esses três fragmentos e, a partir das ideias neles contidas, elaborar a sua redação.

No enunciado da prova de redação fica evidente a limitação dada ao escrevente no que se refere ao tipo de texto: "redija uma DISSERTAÇÃO EM PROSA, argumentando [...]". Solicita-se um texto dissertativo-argumentativo em que 
o escrevente deve construir seu PDV em relação ao tema o trabalho, em função da leitura dos três fragmentos de textos e da imagem que compõem a coletânea. Nesse sentido, não só a proficiência em escrita é analisada, mas também a leitura desses fragmentos.

Vale observar o destaque dado ao tipo de texto ${ }^{11}$ solicitado - dissertação em prosa - marcado na instrução em letras maiúsculas, configurando a restrição coercitiva de escolhas do escrevente na elaboração de sua redação. Como se pode observar, a proposta de redação solicitou ao escrevente que elaborasse um texto dissertativo, apresentando argumentos para justificar seu posicionamento diante do tema dado, o que equivale a dizer que ele deve, obrigatoriamente, construir um texto dissertativo-argumentativo.

Para atender à proposta, o escrevente precisaria relacionar os textos da coletânea e se posicionar diante deles, construindo um PDV. De acordo com a coletânea, ele poderia abordar três aspectos: (1) o trabalho não é intrínseco ao homem, emerge no social e é mutável; (2) o avanço tecnológico não permitiu a total liberdade para a humanidade, pelo contrário, aprisionou-a ainda mais; (3) o trabalho artístico é enaltecido porque transforma algo informe em uma obra cheia de vida. De modo geral, o escrevente deveria, a partir dos aspectos sugeridos pela coletânea, dissertar sobre a relação entre 0 trabalho e o homem, expressando seu posicionamento a favor ou contra os posicionamentos presentes e por ele identificados na coletânea. Ao expressar seu posicionamento, espera-se que o escrevente apresente uma tese e argumente a favor dela para convencer seu leitor. Assim, por meio da construção de argumentos, o escrevente deve estabelecer uma orientação argumentativa coerente com a conclusão desejada.

Como se pode observar, a proposta da prova de redação da FUVEST/USP é, ainda, bastante tradicional no que diz respeito ao gênero requisitado, diferentemente de vários outros vestibulares do país, em que a prova de redação solicita a produção de gêneros variados, como é o caso do vestibular da UNICAMP. É o que mostra o comentário da prova de redação de 2011, publicado, na internet, pela Comvest (Comissão permanente para os vestibulares/Unicamp):

\footnotetext{
${ }^{11}$ A FUVEST considera dissertação em prosa um gênero. Lembro que considero gênero discursivo a redação de vestibular e, tipo textual predominante, o dissertativo-argumentativo (cf. introdução). Essa diferença será objeto de discussão no item 2.2.
} 
A longa tradição dos exames vestibulares, voltada, de maneira geral, para a avaliação da dissertação, tem sido responsável por um engessamento do ensino de redação nas escolas de ensino médio, interrompendo o trabalho com gêneros sob a alegação de que é preciso preparar os alunos para os vestibulares. A nova proposta, portanto, visa a desestabilizar esses modelos e, consequentemente, desautomatizar a relação com a escrita que os alunos e as escolas preparatórias para o vestibular acabam por produzir.

A prova de redação da Unicamp, ao apresentar três propostas obrigatórias de gêneros diversos, sem que os candidatos saibam previamente quais gêneros serão solicitados, oferece a possibilidade de uma relação real e autêntica com a leitura e escrita de textos (COMVEST, 2011).

Outras provas de redação, como a da Universidade Federal de Campina Grande (UFCG - Paraíba) solicitam gêneros, tais como resenha e carta-protesto, e, ao lado destes, outros menos comuns, como: entrevista, memória, palestra.

Outro fator importante que merece destaque nas novas propostas de redação é o jogo enunciativo estabelecido, já de partida, por meio da própria solicitação de gêneros, para cuja elaboração pede-se a simulação do contexto de produção, em relação ao qual o escrevente deve se posicionar de acordo com o explicitado na proposta, como, por exemplo, ocupar a posição de um jornalista que elabora uma entrevista, de um palestrante diante de seu auditório ou de um reclamante numa carta argumentativa, etc. Essa simulação do jogo enunciativo ocorre de outro modo na prova de redação da FUVEST/USP, em que se frisa, a meu ver, mais o tipo textual do que o gênero em si. Neste caso, o posicionamento enunciativo vai depender da leitura dos textos da coletânea e/ou do recorte do tema produzidos pelo candidato.

Apesar disso, nos dois modelos de prova, a relação locutor/alocutário permanecerá aquela do que designo (e discutirei mais adiante) gênero redação de vestibular, a saber, a relação avaliado/avaliador, ora predominando o exercício com determinados gêneros, ora predominando o exercício com o tipo textual tradicional, o dissertativo-argumentativo. Em ambos os tipos de prova, portanto, o jogo enunciativo põe em ação candidato-escrevente e corretor-leitor.

Passo, neste ponto, a delimitar, de forma mais precisa, as hipóteses e as perguntas de pesquisa que se fizeram presentes ao estabelecermos a redação de vestibular como objeto de análise. 
A problemática da produção do texto escrito em ambiente escolar direcionou a pesquisa para uma abordagem teórica que abarcasse diferentes áreas do conhecimento - linguística textual, argumentação, enunciação e análise do discurso -, possibilitando o diálogo entre elas. Ao assumir a perspectiva enunciativodiscursiva, impõe-se a referência a campos de pesquisa interdisciplinares, a fim de se estabelecer uma visão sobre o texto bem como sobre a produção de um gênero discursivo em um contexto de produção tão determinado quanto o do exame vestibular.

Com base nesse entrecruzamento teórico, que orientou a leitura do corpus, foi concebido o objeto de análise, que consiste em investigar como se constrói o PDVD nos textos estudados. Procurando uma resposta a essa questão inicial, tomei como meta, no decorrer da análise, a comprovação de dois conjuntos de hipóteses preliminares:

1. no que se refere à construção do PDVD: (a) o escrevente constrói o PDVD e demarca sua defesa por meio do uso de diferentes modos de qualificar; e (b) o escrevente constrói o PDVD, mas não faz uso dos modos de qualificação para demarcar seu posicionamento;

2. no que se refere à mobilização de saberes: (a) o escrevente, para sustentar seu posicionamento diante do tema "o trabalho", mobiliza seus saberes e os utiliza como uma das estratégias para a construção do PDVD; e (b) os diferentes modos de mobilizar saberes são constitutivos do gênero discursivo analisado, mas moldados pelas representações de escrita, do acontecimento - o evento vestibular -, da imagem sobre si e do outro - seu interlocutor -, bem como pelas práticas letradas do candidato, incluindo nestas, o modo como lê e interpreta os enunciados da prova de redação.

Para testar essas hipóteses, as seguintes perguntas orientam a análise:

(1) De quais estratégias o escrevente se utiliza para construir o PDVD e qual a relação delas com os diferentes modos de qualificar, na organização do texto?

(2) Como articula essas estratégias com diferentes fontes de saber ao construir o PDVD, na organização do texto? 
(3) Como se dão os deslocamentos de fronteiras entre os eixos teóricos adotados, a saber: (a) o enunciativo; (b) o propriamente argumentativo; e o (c) discursivo? Ou seja, como, afinal, na totalidade do corpus, o PDVD se constrói?

(4) Que contribuição a explicitação da construção do PDVD na organização do texto pode dar para melhoria da qualidade do ensino de língua materna e da escrita em particular?

Diante da possível flexibilidade dos gêneros, formulada por Bakhtin como relativa estabilidade, uma atenção especial se volta para as escolhas linguísticas do escrevente, principalmente no que se refere aos elementos qualificadores, vistos como estratégia argumentativa.

\subsection{Noções de letramento e de escrita como prática social}

Neste item, trato, de forma mais abrangente, do estudo da escrita, situando-o nos estudos do letramento e, de modo mais particular, da concepção de escrita como prática social e suas implicações para a análise do texto.

O conceito de letramento vem sendo construído a partir de estudos como os de Street (1984); Tfouni (1995); Kleiman (1995); Soares (2001); Corrêa (2001), dentre outros. Entre concordâncias e dissonâncias, há um ponto comum nesses diferentes estudos: o letramento está relacionado às práticas discursivas, sejam elas escritas ou faladas e, nesse sentido, está vinculado às práticas sociais de leitura e de escrita. Alguns autores tomam como parâmetro para o letramento as letras; isto é, tomam o estudo do letramento a partir da alfabetização, caracterizando cada sujeito em determinado grau de letramento. Esse grau varia de acordo com a sua desenvoltura nas práticas de leitura e escrita. O letramento é visto tendo como parâmetro a escrita a partir da alfabetização, por isso, o letramento é definido pelo "impacto social da escrita".

Nesse sentido, a existência/presença da escrita é condição para o letramento, que se localiza como posterior à alfabetização. Nessa perspectiva, o ensino da produção textual é, muitas vezes, visto como aprimoramento da alfabetização e esta, vista como um código. É a própria escrita que está em jogo nessas definições, 
em que ou o letramento é visto como prática e se realiza em eventos, ou é visto como o próprio impacto da escrita na sociedade. Em outra concepção de letramento, o que dá contornos à problemática do letramento não é a escrita ou seu resultado na sociedade em si, mas o sujeito que se apropria (ou não) dela. Trata-se, nesse sentido do "estado ou condição de indivíduos ou de grupos sociais de sociedades letradas que exercem efetivamente as práticas sociais de leitura e de escrita, participam competentemente de eventos de letramento" (SOARES, 2002, p. 145 grifos da autora). Entretanto, há outra concepção de letramento que não diz respeito somente à escrita em suas práticas ou ao sujeito que detém o código escrito, tampouco, aos graus de letramentos do sujeito em função dessa apropriação e uso; em sociedades ágrafas, por exemplo, o letramento também está presente (STREET, 1984). Nesse sentido, outra concepção de letramento se coloca: aquela que não se refere exclusivamente às práticas de leitura e de escrita a partir da alfabetização; o letramento vai além desse patamar e, por isso, não deve ser confundido como sinônimo de alfabetismo em contraposição a analfabetismo, devendo ser considerado no plural.

Segundo Corrêa (2001), tomar o letramento a partir da alfabetização é limitar o seu sentido, que, ainda segundo o autor, pode ser considerado de modo mais amplo, estendendo-se "a condição de letrado para um momento anterior à alfabetização" (p. 21). A escrita, nessa concepção ampla de letramento, não é o limite para a condição de letrado, nem seu ponto de partida. Para o autor, 0 letramento está, também, nas práticas de tradição oral, uma vez que ambas são movidas por modos específicos de registro de uma memória cultural.

Desse modo, a escrita não é parâmetro acabado para o ideal de língua padrão, que, afinal, nunca se materializa como tal nas falas particulares dos chamados falantes cultos. Não é, também, fruto apenas da alfabetização nem obtida por meio de modelos acabados. Pelo contrário, ela é resultado de um processo e, por isso, está vinculada às relações entre o escrevente e o seu trabalho com a linguagem em suas práticas de leitura e de escrita. $O$ que equivale a dizer, com relação ao estudo da produção textual, que a preocupação não é com a forma linguística em si, mas com a prática discursiva de leitura e de escrita, ou seja, com a dinamicidade da língua em uso concreto, que envolve um sujeito ${ }^{12}$, o escrevente,

${ }^{12}$ A noção de sujeito adotada será explicitada mais adiante, no item 1.3. 
historicamente situado. Adoto, assim, o conceito de letramento enquanto fruto do registro da história do sujeito, seja esse registro oral ou escrito, vinculado e condicionado ao evento em que ele se realiza.

No que se refere à prática didática da escrita, com destaque para a redação, ela segue ainda modelos considerados ideais por aqueles que concebem a produção textual em função de produtos prontos, acabados e, por isso, continua a aplicar modelos cristalizados, artificiais, em relação ao uso concreto da língua. Tenta-se, por meio de formas fixas, padronizar o modo de escrever determinado texto, determinado gênero. Nesta concepção de escrita e de seu ensino, o gênero é visto somente em suas estruturas fixas, regulares, que devem ser ampliadas, complementadas em suas "lacunas" pelo escrevente. No âmbito do ensino de redação, é o que se pode chamar de didatização do gênero, que, de diferentes modos, elegem como meta o modelo já acabado e pronto. Nem sempre foge a essa regra o trabalho didático que consiste na elaboração de uma série de sequências didáticas com o passo a passo para se chegar à escrita de um gênero "bem" escrito, uma vez que, não raro, a cada sequência reescrita, faz-se a higienização do texto, limpando-o de suas "impurezas", rumo a uma escrita homogeneizada. Desse modo, diferentes didatizações da escrita podem inserir-se no domínio do letramento que Street (1984) denominou de "autônomo", já que tomam o modelo acabado como partida e como chegada, distanciando-se do real tratamento da escrita como prática sociodiscursiva de uso concreto da língua.

Essa escrita congelada é reconhecível nos enunciados das redações, fruto de um ensino calcado no produto finalizado e não situado em uma prática discursiva efetiva. No entanto, há que se considerar que não há como forjar determinadas situações de enunciação que não estejam vinculadas ao contexto escolar como ponto de partida. O que existe na escola, muitas vezes, é a simulação da situação de enunciação, sendo, porém, sempre o professor um dos lados da interação. Apesar dessa restrição, nem sempre a simulação é um problema, desde que seja trabalhada de modo a contemplar outros interlocutores. No que se refere ao ensino da redação como preparação para o vestibular, não há como reproduzir a situação de enunciação verdadeira de um exame vestibular. Há (ou pode haver) uma tentativa de imitar essa situação. Trata-se, então, de um ensaio, de um treino em que o professor simula a interlocução entre o aluno-vestibulando e o professor- 
corretor. Essa imitação atinge, sobretudo, os papéis dos escreventes, mas nunca efetivamente uma prática legítima da escrita de um gênero. No entanto, não deixa de ser uma tentativa de se trabalhar a escrita desse gênero na escola.

Pode-se, pois, questionar: qual é o papel da escola? Creio que à escola cabe o papel de ensinar a escrita enquanto processo sócio-histórico. Cabe à escola não só tratar da aquisição e domínio da escrita pelo aluno, mas tratá-la como inserida em práticas de letramento, ou seja, em práticas discursivas. A escrita de um gênero passa a ser vista como fenômeno social e como tal, deve-se "prestar atenção em algumas de suas características: o espaço de posições, o processo histórico de sua ocupação, os valores em jogo, as trajetórias das carreiras dos agentes e o habitus assumido pelo engajamento no campo" (HANKS, 2008, p. 45, grifo do autor). Essas características, numa situação de enunciação forjada, não são assumidas como verdadeiras pelo escrevente, que acaba não se engajando devidamente como numa situação verdadeira de enunciação. Estudar a escrita tendo como parâmetro o letramento enquanto registro da história do sujeito é não perder de vista a dinâmica da prática social e discursiva da produção de um gênero.

Na dinâmica social de construção de conhecimentos, os agentes culturais são complexos e heterogêneos, da mesma forma que a apreensão dos bens culturais pelo sujeito. Esse registro é marcado no enunciado como uma retomada do já-dito, possibilitando certo tom - carregado de valores - ao que é dito, resultando em efeitos polifônicos de sentidos. O já-dito, cravado na memória discursiva do escrevente, reapresenta-se no dito, construído no tempo da enunciação, em que os letramentos vivenciados pelo sujeito são expostos em seu enunciado, em função e determinados pela enunciação. Nesse sentido, pode-se considerar que há letramentos vividos pelo escrevente e letramentos por ele concebidos, no sentido de tomar determinados letramentos e não outros, para carregar os enunciados de certos efeitos tanto no que diz quanto no modo como se diz, principalmente para causar determinados efeitos no interlocutor. Ao trazer para o enunciado os já-ditos, o escrevente traz igualmente representações redimensionadas a partir de suas rememorações, de sua memória discursiva. Nesses modos de dizer com base em seus letramentos vividos e concebidos, o gênero vai se compondo em sua singularidade e relativa estabilidade. Nesse ambiente, o PDV vai igualmente sendo construído, na relação entre o histórico e o linguístico. Por isso, há saberes nos 
enunciados das redações; saberes que vêm da memória, da vivência, dos letramentos do escrevente.

O letramento é fruto também das diferentes leituras e dos modos de leitura do escrevente. Tendo como fonte imediata de leitura os fragmentos da coletânea, 0 escrevente, muitas vezes, prende-se mais a essa fonte ao invés de recorrer a fontes outras, na tentativa de atender ao solicitado no exame. Os diferentes modos como intertextualiza esses fragmentos da coletânea e, também, os enunciados das questões (não da redação) da prova de português, ambos ali, mais imediatamente, em suas mãos; e, ainda, enunciados de outras esferas, diversas das representadas na coletânea, nas instruções ou nas questões de português, revelam, todos eles, um sujeito trabalhando a linguagem, agindo e fazendo-se ator por meio dela, estruturando os gêneros do discurso e, ao mesmo tempo, sendo coagido por eles. É nesse sentido que o gênero é concebido como prática discursiva, no exercício memorialista de seus letramentos, ou seja, na retomada dos já-ditos, que são atualizados, condicionados e determinados pela enunciação. Entra também, nesse jogo, o saber sobre o gênero, que é construído em suas regularidades e reconstruído em suas singularidades.

O gênero redação de vestibular torna-se, assim, bastante peculiar no sentido de que sua composição é bastante singular e, ao mesmo tempo, bastante regulada socialmente. Singular porque o sujeito que escreve tem seu modo de ler e interpretar os enunciados da coletânea, como também seu modo de escrever a redação, baseado em suas representações e em seus letramentos. O gênero é constituído em função desse sujeito-leitor-escritor, com suas características próprias, com sua história e valores representados. São esses aspectos que compõem a historicidade do gênero e da constituição da escrita como prática social. É nesse sentido que concebo a escrita como processo, como resultado das ações do sujeito na história e da história no sujeito em sua escrita; como prática social, enfim.

Assumir a escrita como parte de um processo sócio-histórico é não dar margem à padronização como o único e aceitável modelo de escrita, é não submeter-se a uma única e exclusiva língua, aquela que é avaliada socialmente como correta e, por isso, legítima. Há que se considerar o gênero (e seu ensino) como elemento social e historicamente constituído, como prática discursiva e situada. Há, portanto, no processo de escrita, um escrevente que se posiciona (ou 
tenta posicionar-se), buscando se fazer entender e se entendendo, se construindo e se constituindo como sujeito.

Essas marcas históricas podem ser vistas pelo professor/corretor como a "novidade" trazida pelo aluno na "adequação" do texto buscada por ele. Trata-se de investigar a escrita desse escrevente sob um novo ângulo, o da "novidade na adequação" que permitiria que olhássemos:

[...] para certas presenças surpreendentes de fragmentos de gêneros, manifestadas em diferentes dimensões da linguagem, não como erro nem como inadequação, mas como um registro pontual e singular, porque histórico, do estado do processo discursivo em que o sujeito se situa no que se refere, especificamente, ao posicionamento enunciativo que ocupa em relação aos modos de enunciação falado e escrito (CORRÊA, 2006, p. 272).

[...] Pensar a escrita segundo essa nova idéia de adequação desmantela, de imediato, a prática que se baseia em enfatizar os produtos, isto é, em última instância, a velha prática do decalque de modelos de textos, às vezes mascarada com novas noções, como por exemplo, as atividades dirigidas ao adestramento do aluno em uma série de gêneros textuais (Op. Cit., pp. 279-80).

No ensino da escrita é importante, portanto, considerar a escrita enquanto processo e não somente como produto resultante de um "recorta e cola", uma vez que é nesse processo que o escrevente se posiciona, ocupa um lugar social na enunciação e, a partir dele, deixa suas marcas no texto. É essa a concepção de escrita adotada para a pesquisa, ou seja, a que considera o caráter sócio-histórico das práticas de letramento, em que os usos da escrita e da leitura são sustentados como práticas discursivas.

Tratar de produção textual, sem contextualizá-la nos estudos do letramento visto de forma ampla, seria desconsiderar a concepção de linguagem enquanto ação e interação, na qual as práticas sociais de leitura e de escrita estão envolvidas. Seria desconsiderar o contexto sociocultural e histórico do escrevente e suas representações, que incluem as representações sociais da escrita e as que atuam sobre o próprio tema da redação do vestibular/2006, o do trabalho. A redação de vestibular é um momento do processo de letramento e reflete as práticas sociais de seus escritores, os vestibulandos. Nessas práticas estão inclusas não só as de leitura e escrita, mas aquelas vinculadas às práticas da oralidade, principalmente, aquelas que acontecem no espaço escolar, por exemplo, a aula expositiva. A redação de vestibular enquanto prática social exige considerar, em sua análise, 
diferentes letramentos: o escolar, uma vez que a redação de vestibular é uma prática letrada socialmente situada em condições específicas de letramento: trata-se de uma avaliação proposta por uma instituição de ensino; e aqueles letramentos não restritos à escola, ligados ao contexto sociocultural e histórico do escrevente, isto é, os letramentos da esfera familiar, do trabalho, religiosa, etc. As atividades dessas esferas são parte do letramento do escrevente e estão, de alguma forma, representadas em sua escrita.

A redação de vestibular, neste âmbito, guarda sinais dos processos de letramentos vivenciados pelo escrevente: suas leituras, aulas, conversas cotidianas, mídia, etc.. Esses sinais, que caracterizam a heterogeneidade da escrita (CORRÊA, 2001, 2004), revelam aspectos da heterogeneidade mostrada e de seu papel de negociação com a heterogeneidade constitutiva do sujeito e do discurso (cf. AUTHIER-REVUZ, 1990), porque, sendo o escrevente um sujeito social, situado historicamente, suas singularidades estarão registradas em seu texto, assim como suas representações, marcas de regularidade linguística de pertencimento a grupos. O letramento é, então, fruto do registro da história dos sujeitos, seja ele do campo do oral ou do escrito.

Além das práticas de leitura e escrita, há também os eventos de letramento, vistos como os lugares em que essas práticas ocorrem (KLEIMAN, 1995). A redação de vestibular está inserida em uma prática social letrada: uma avaliação por meio da escrita. Ela é parte integrante de um evento de letramento: o exame de redação, que trato, na pesquisa, como acontecimento discursivo. Portanto, a redação é vista não somente como um produto, mas como processo, porque é essencial considerar, para a análise, o enunciado e a enunciação e ir além deles, isto é, interpretá-los. Não basta apenas olhar para o dito, mas principalmente para o modo de dizer esse dito e seus respectivos efeitos de sentido. Trata-se de um olhar conjunto, concomitante: olha-se para o dito e para o modo de dizer. É preciso observar as propriedades linguísticas dos enunciados, mas olhá-las na relação com as propriedades socioculturais e históricas também. Esses elementos mostram-se, direta ou indiretamente, no texto. Faz-se necessário buscá-los nos textos, ou seja, analisar as redações como práticas social e discursivamente situadas. 


\subsection{Concepção de linguagem}

Tendo apresentado o letramento como registro cultural de um grupo/de um povo; a escrita como processo, como prática social constituída heterogeneamente e materializada por meio de um escrevente, um sujeito histórico, ele próprio constituído sob o jogo dialógico da linguagem estamos em condição de afirmar que, para além dos limites deste trabalho, a concepção de linguagem adotada é (sempre) inseparável da concepção de sujeito.

A linguagem não é expressão do pensamento, concepção para a qual tanto a presença, mesmo que virtual, do outro quanto a explicitação da situação de enunciação seriam desnecessárias, isto é, para a qual a interação não teria importância. Também não é instrumento de comunicação, concepção para a qual se valoriza o código para a correta transmissão e recepção de mensagens. Essas concepções de linguagem são recusadas, por exemplo, por Benveniste, ao destacar o caráter subjetivo da linguagem. Segundo o autor, é "na linguagem e pela linguagem que o homem se constitui como sujeito" (BENVENISTE, 1989, p. 286). Benveniste avança ao trazer a consideração do sujeito para a discussão do que entende por linguagem. Entretanto, o autor centraliza a discussão na relação do sujeito com a enunciação, como ato individual que mobiliza a língua por conta própria, ao se apropriar do aparelho formal da enunciação. Trata-se, nesse sentido, de uma concepção de linguagem que restringe a relação do sujeito apenas à enunciação vista como o "colocar em funcionamento a língua por um ato individual de utilização" (BENVENISTE, 1989, p. 82), sem considerar as implicações históricosociais. A linguagem não pode ser encarada como fruto de um sistema estável que resulta da dicotomia língua/fala ou de análise apoiada apenas em fatos individuais e estruturais, que consideram o sentido pronto no texto, excluindo a relação do sujeito com a linguagem e com o seu outro, afastada das coerções sociais. Há que se considerar, assim, que o sujeito está imerso na atividade social em que a língua se estabelece em seu uso concreto, ou seja, no processo interativo, que se dá num contexto específico de enunciação.

O estudo da língua e do texto amplifica-se. Antes voltado apenas para os aspectos internos, hoje, resulta da tensão interioridade versus exterioridade. O que implica dizer que os sujeitos da enunciação não estão totalmente livres, mas 
submetidos a esses fatores - internos e externos -, uma vez que a expressão não está no indivíduo, não é fundada nele, mas determinada "pelas condições reais da enunciação em questão, isto é, antes de tudo pela situação social mais imediata" (BAKHTIN, 1986, p. 112). Não há apenas um sujeito enunciando, mas sujeitos e discursos interagindo. A essa concepção de sujeito estarão remetidas as referências que doravante farei aos escreventes.

O escrevente participa, desse modo, ativamente desse processo, ao exercer ações sobre a linguagem, com ela, para ela (GERALDI, 1999). Realiza um trabalho contínuo com a linguagem, que não é unilateral, mas dialógico, pois a linguagem acontece na interação, no espaço entre o um e o outro/Outro ${ }^{13}$. Nesse espaço discursivo, os sujeitos - eu-tu-outros - se constituem, se constroem.

De acordo com Bakhtin (1986), a verdadeira substância da língua é constituída pela interação verbal que se realiza com a enunciação. É nesse aspecto que o conceito de enunciação de Benveniste diferencia-se do de Bakhtin. Benveniste trata a enunciação como um ato individual de realização da língua, já para Bakhtin:

a enunciação é o produto da interação de dois indivíduos socialmente organizados e, mesmo que não haja um interlocutor real, este pode ser substituído pelo representante médio do grupo social ao qual pertence o locutor. A palavra dirige-se a um interlocutor: ela é função da pessoa desse interlocutor: variará se se tratar de uma pessoa do mesmo grupo social ou não, se esta for inferior ou superior na hierarquia social, se estiver ligada ao locutor por laços sociais mais ou menos estreitos (pai, mãe, marido, etc.). Não pode haver interlocutor abstrato; não teríamos linguagem comum com tal interlocutor, nem no sentido próprio nem no figurado (BAKHTIN, 1986, p. 112, grifos meus).

Conceber a enunciação como o produto da interação é afirmar que ela se constitui, pois, nas situações concretas de usos da língua, isto é, na relação entre os interlocutores. Trata-se, nesse sentido, de assumir uma concepção de linguagem que, conforme Bakhtin (1986), privilegia a enunciação. O que permite dizer que prevalece o olhar para os espaços interacionais, uma vez que é nesses espaços discursivos que o escrevente se constrói, em função das interações com seu(s) outro(s).

${ }^{13}$ Utilizo a distinção feita por Authier-Revuz (1990) entre outros (com minúsculas) e Outro (com maiúscula). Assim, Outro refere-se ao inconsciente da teoria lacaniana, à ideologia, enquanto o outro corresponde a outros discursos, ao interlocutor. 
Para Possenti (2001, p. 228), a linguagem é "resultado do trabalho de seus construtores/usuários". Isso pode ser percebido, por exemplo, nas escolhas do escrevente, quando seleciona determinados recursos linguísticos e não outros. Essa escolha está atrelada à situação de enunciação, a quem é esse outro, ao processo interativo como um todo. Essa situação imediata condiciona as escolhas do escrevente, que variam conforme a esfera na qual o enunciado está inserido (BAKHTIN, 1992). Os elementos que sustentam essas escolhas também evidenciam - caráter dialógico da linguagem, pois o escrevente faz suas escolhas não individualmente, mas exatamente em função do outro/Outro, condicionado pela situação de enunciação, subordinado às coerções dessa situação, como também do próprio gênero.

Assumir uma concepção de linguagem enquanto ação - no caso deste trabalho, ação do escrevente sobre/na/pela linguagem -, muito mais do que assumila como expressão do pensamento ou instrumento de comunicação, permite abrir para a consideração da linguagem como poder:

A estrutura da relação de produção linguística depende da relação de força simbólica entre os dois locutores, isto é, da importância de seu capital de autoridade [...] a língua não é somente um instrumento de comunicação ou mesmo de conhecimento, mas um instrumento de poder. Não procuramos somente ser compreendidos mas também obedecidos, acreditados, respeitados, reconhecidos (BOURDIEU, 1983, p. 160-1).

Por meio da relação ação/interação/poder, podem-se provocar mudanças na sociedade, mudanças de posicionamentos, de comportamentos. O trabalho com a linguagem é, pois, também um agir no mundo. Ao realizar seu trabalho com a linguagem, apropria-se de valores sociais, que ficam marcados em seu enunciado de diferentes maneiras. Traduzindo-se para o trabalho do escrevente, a escrita é, por isso, vista como processo e não como produto; ela é registro do processo interativo.

$\mathrm{Na}$ qualidade de processo, destaco algumas condições para a produção escrita propostas por Geraldi: que o escrevente tenha o que dizer; tenha uma razão para dizer o que se tem para dizer; tenha para quem dizer o que se tem para dizer; defina estratégias para realizar esses fazeres (GERALDI, 1997, p. 137). Há, em outras palavras, lugares a ocupar. 
Dito de outro modo, é impossível conceber o um fora da relação com o outro, sem considerar as relações sociais e as implicações ideológicas (BAKHTIN, 1986). Desse modo, ao tratar do sujeito na concepção de linguagem como ação/interação/poder, faz-se necessário entender que ele ocupa lugares sociais, assume posições, constrói PDVs que são determinados socialmente e na relação direta com a situação de enunciação.

O exame vestibular, por se tratar de uma avaliação institucional, estabelece normas para o escrevente. Este, para corresponder a essas exigências, ficcionaliza seu interlocutor para dar conta do papel que deseja e precisa desempenhar diante dele. $O$ escrevente se vê preso às imposições institucionais, tentando cumprir o que Ihe é solicitado. No entanto, por ser, também ele, produto de relações sociais e constituído historicamente como sujeito, pode romper (e frequentemente o faz) com fronteiras previstas pela instituição com a qual se relaciona, gerando um conflito. No texto, o escrevente se constrói na tensão entre o ritual do evento vestibular (regido pela instituição), o sistema da língua (normatividade de seus usos), as restrições do discurso (coerções do gênero, por exemplo), os lugares sociais e suas vinculações ideológicas (regidos por determinações sócio-históricas e representados no discurso pelas posições enunciativas assumidas). Pode-se, pois, dizer que o escrevente, diante desse quadro, se constitui discursivamente, isto é, no espaço discursivo entre o interior da língua e o seu exterior, o social e o histórico. É desse lugar que ele trabalha com a linguagem e interage com seu outro/Outro. A concepção de sujeito aqui aplicada ao escrevente não é a da "polaridade centrada ora no eu ora no tu [...], mas [a que se dá] no espaço discursivo criado entre ambos. O escrevente só constrói sua identidade na interação com o outro." (BRANDÃO, 1997, p.62). Desse modo:

A idéia básica mobilizada para postular uma noção não ingênua de sujeito é opor a idéia de sujeito à de estrutura: se as estruturas fossem acabadas, sem frinchas, se igualassem efetivamente em todos os sentidos os elementos a que se referem (indivíduos numa sociedade, átomos linguísticos numa língua), a única definição possível de sujeito seria pela sujeição. Mas, então, as sociedades e as línguas não mudariam. Os sistemas são instáveis, e o são pela ação dos indivíduos. E é, portanto, pela ação, ação indiferenciada, que o sujeito será definido (POSSENTI, 2001, p. 2-3).

Deve-se incluir, nessa concepção de escrevente, a de construção de sentidos. Os sentidos são construídos nesse mesmo espaço discursivo da 
constituição do escrevente, isto é, um espaço sócio-histórico. Por isso, ele não é fonte nem origem do sentido, como também não controla o seu dizer. O sentido "é determinado pelas posições ideológicas colocadas em jogo no processo sóciohistórico em que palavras, expressões, proposições são produzidas" (PÊCHEUX, 1997, p. 160). Essas noções são indissociáveis e ambas são construídas no espaço interativo. O escrevente está, então, distante da instância individual, o vestibulando, o sujeito empírico. Ele deve ser compreendido na instância social, em que prevalece o discursivo, sofrendo coerções tanto ideológicas quanto genéricas. É nessa tensão que o escrevente se constitui.

\subsection{A redação de vestibular como gênero discursivo}

Ao adotar a perspectiva enunciativo-discursiva para estudar a redação de vestibular, considero não só os aspectos textuais, em que prevalece o olhar para a estrutura do enunciado, mas principalmente o que a constitui como gênero discursivo e, assim, aspectos que a definem como tal: conteúdo temático, estrutura composicional e estilo. Nessa direção, procuro me distanciar da idealização costumeira da escrita, no sentido de que se busca sempre eleger o modelo de texto ideal, mais adequado, para, ao contrário, priorizar as marcas enunciativo-discursivas voltadas à construção do PDVD nesses textos.

A priorização desses aspectos está diretamente ligada à perspectiva teórica assumida para a pesquisa, em que alguns conceitos são fundamentais, como, a noção de letramento e a concepção de escrita como prática social (item 1.2), a concepção de linguagem e de sujeito (cf. item anterior, 1.3) e a definição de gênero baseada nos postulados de Bakhtin $(1992,2003)$, bem como a caracterização que ora busco proceder da redação de vestibular como gênero discursivo.

\section{A. A redação de vestibular é um gênero?}

Para melhor compreender o processo da produção escrita, parto, portanto, da perspectiva enunciativo-discursiva para a abordagem dos textos, pois considero que ela dá conta dos aspectos envolvidos na produção da escrita como prática social. Dessa perspectiva, assumo a redação de vestibular enquanto gênero discursivo. 
Para firmar esse meu posicionamento, vale destacar dois aspectos que Corrêa (2011) traz para essa discussão: primeiro, a ênfase não é dada no "tipo" de texto, ou seja, em sua estrutura composicional isoladamente; segundo, considero o exame vestibular um evento de letramento (KLEIMAN, 1995), visto como um acontecimento discursivo, e não uma atividade limitadora da análise ao estritamente linguístico (CORRÊA, 2011 p. 11-2). Comentando os gêneros do discurso e os tipos de texto solicitados para produção nos vários exames vestibulares, o autor acrescenta que:

considerando:

- a interação social específica (avaliado/avaliador) válida para todos esses textos;

- o comportamento verbal semelhante mesmo na produção de tipos diferentes;

- as escolhas temáticas filtradas por um interesse educacional (os textos são escritos sobre temas relevantes da atualidade); e

- as soluções estilísticas essencialmente ligadas ao diálogo com a instituição avaliadora que comportam; pode-se, de maneira operatória e sem pretensão classificatória, dizer que o conjunto dessas restrições configura um gênero do discurso que vem sendo especificado pelo predomínio de certos tipos de texto, como, por exemplo, o dissertativo e o narrativo.

Teríamos, então, tipos - predominância do dissertativo ou narrativo, combinados em diferentes proporções - produzidos como gênero redação de vestibular. De modo semelhante, a carta, que é um gênero do discurso, seria, no contexto do vestibular, uma proposta de escrita de um tipo argumentativo particular - aquele com interlocução explícita -, produzida, ela também, como gênero redação de vestibular (CORRÊA, 2011, p. 637, grifos do autor).

Desse modo, as considerações de Corrêa vão ao encontro do que assumo: a redação de vestibular enquanto gênero discursivo e, no caso da FUVEST, do tipo predominante dissertativo-argumentativo. Além disso, considerar a redação de vestibular um gênero discursivo permite que se trabalhe "em função de sua produtividade no reconhecimento de processo de constituição do texto, modo de repor o encontro do produtor do texto com seu produto" (CORRÊA, 2011, p. 638, grifo meu).

É nesse encontro do escrevente com seu texto que o exame vestibular tornase um acontecimento discursivo, em que o escrevente articula língua, texto e discurso ao por em ação suas representações sobre a/por meio da escrita. Busco, nesse trabalho do escrevente, as representações firmadas no texto pelas modalizações e, sobretudo, pelas adjetivações o que não significa restringir a 
análise ao estritamente linguístico, mas estabelecer o diálogo entre o linguístico e o discursivo.

Para entender a redação de vestibular como gênero discursivo, é importante, também, diferenciá-la de redação escolar, a fim de evitar alguns equívocos. Como o próprio nome diz, redação escolar é aquela feita para a escola, ou melhor, para o professor como único interlocutor. A produção textual é, nesse contexto, uma tarefa escolar e o ensino da escrita se dá sob a influência do "fantasma" de uma escrita suposta como ideal, tida como irrepreensível do ponto de vista da correção. Os olhares se voltam apenas para a superfície textual da produção do aluno. O ensino dessa escrita aprofunda mais o estudo da tipologia textual em detrimento do gênero, não levando em conta aspectos ligados ao uso social da escrita, em que se privilegia a situação de comunicação como um todo, ou seja, o gênero escolhido, sua função social e o papel dos interlocutores.

Nessa forma mais tradicional do ensino de redação na escola, o gênero não tinha lugar. Era apresentado um tema a ser desenvolvido de acordo com o tipo textual estabelecido pelo professor: narração, descrição ou dissertação. Vários manuais foram criados nessa concepção de ensino da escrita. Com o advento do PCN (Parâmentros Curriculares Nacionais) de Língua Portuguesa, houve uma tentativa de mudança, abrindo-se espaços para o ensino da produção a partir dos gêneros, uma tendência contemporânea. Nesse contexto, surgem diferentes nomenclaturas, muitas vezes para um mesmo elemento como, por exemplo, tipo de texto, sequência textual, modos de organização do discurso, domínio discursivo e gênero textual, gênero do discurso, gênero discursivo.

A discussão que se segue, atinente à relação entre redação escolar e redação de vestibular, baseia-se em pesquisas recentes, nomeadamente as de Marcuschi (2004) e Dutra (2008). A redação escolar é considerada um gênero discursivo, porque atende aos requisitos para isso: possui uma situação de enunciação, apesar de restrita, é uma situação de enunciação real, uma vez que se estabelece entre o aluno e o professor um canal de comunicação que, segundo Bakhtin (1992, 2003), só pode se concretizar por meio dos gêneros do discurso. Nessa situação de enunciação, o aluno sabe em que ele está sendo cobrado e a que critérios deve atender para ter o aval de seu interlocutor, o professor e, cumprir, não diretamente uma função comunicativa, mas dar conta de uma tarefa escolar: a 
escrita de um texto para ser avaliado com critérios determinados pelo professor corretor. A redação escolar é, pois, fruto de uma situação de comunicação simulada, que tenta se fazer passar por real. Enquanto ela for tratada apenas como tal, será difícil para o estudante apropriar-se da escrita em seu uso social.

Já a redação de vestibular, conforme anunciado na introdução, é assumida como um gênero discursivo porque está inserida em uma situação de comunicação efetiva - o exame de redação do vestibular. Trata-se de um gênero produzido em uma situação real de comunicação, com interlocutores igualmente reais e uma função social bem estabelecida. A função da redação escolar é o ensino da escrita; é um gênero que nasce e permanece dentro da escola. A redação de vestibular tem também uma circulação restrita e escolar, porque avalia a escrita do vestibulando com fim específico. Sua circulação se restringe ao ambiente de correção, isto é, à banca corretora e se encerra, normalmente, nos arquivos temporários da fundação que gerencia o exame vestibular, até ser destruída ou ir para a mão de um pesquisador. Algumas redações da FUVEST circulam também na internet, em um site que apresenta aquelas consideradas as melhores pela fundação. Apesar dessa circulação mais reservada do que as de outros gêneros, ela nasce numa situação real de enunciação, com interlocutores cujos papéis sociais são legítimos. Nessa direção, a redação de vestibular é um gênero discursivo porque acontece em uma situação de comunicação verdadeira, possui uma função social específica, ou seja, é uma prática social mais ampla do que aquela restrita somente à escola.

Apesar de a redação escolar e a redação de vestibular serem gêneros discursivos diferentes, há algumas semelhanças entre elas que merecem destaque. No que se refere ao contexto de produção, que são evidentemente diferentes, há, entretanto, alguns aspectos em comum, como a situação de avaliação da escrita, o atendimento a uma proposta elaborada com esse fim, isto é, o de avaliar a escrita por meio da elaboração de um gênero especificado na própria proposta de redação. Ambos exigem um posicionamento do escrevente diante de determinado fato ou tema, estabelecendo o uso do tipo textual predominante, 0 dissertativoargumentativo, como é o caso do exame de redação da FUVEST/USP, ou mesmo em uma carta argumentativa, como já foi o caso do vestibular da UNICAMP. Outras universidades (cf. PILAR, 2002; PAVANI, KÖCHE \& BOFF, 2006; SILVA, 2009; SILVA \& LINO DE ARAÚJO, 2009a; 2009b), em seus exames, solicitam a 
elaboração de gêneros diferentes do solicitado no vestibular da USP, como relato, resenha, memória, etc. Nesses diferentes gêneros que transmutam do seu local de circulação de origem, para se tornarem redação de vestibular, sempre o interlocutor será a banca examinadora, mesmo que na proposta da prova de redação haja outros interlocutores predeterminados conforme o gênero estabelecido para o candidato escrever.

A perspectiva enunciativo-discursiva, ao mesmo tempo textual e discursiva, possibilita analisar a redação de vestibular sob diferentes aspectos: dialógicos e polifônicos, nos quais se fundamenta a definição de PDV adotada neste trabalho; bem como sob aspectos voltados para a construção da argumentação, mais ligados à herança deixada pela retórica. Favorecendo a caracterização da redação de vestibular como gênero, a perspectiva enunciativo-discursiva abre espaço para a consideração da articulação entre aspectos enunciativos e discursivos, permitindo, desse modo, abordar aspectos dialógicos tanto na sua dimensão interacional quanto em sua dimensão interdiscursiva.

A abordagem enunciativo-discursiva traz, por fim, à tona as tomadas de posição do escrevente, seus posicionamentos, que se desdobram discursivamente nos enunciados. A expectativa é que ela possa, pelo que permite analisar da construção de PDVs e do PDVD no específico gênero do discurso em questão, contribuir para o campo aplicado, como, por exemplo, para o ensino e a aprendizagem da escrita. A construção de PDVs e a do PDVD, em virtude de sua própria constituição, são mais bem analisadas no âmbito do gênero do discurso em que aparecem; no caso, no âmbito do gênero redação de vestibular.

Uma última observação, mas não menos importante, sobre o gênero redação de vestibular vem a partir do que propõe Buin $(2006$; 2007) sobre a ficcionalização nos textos escolares. No que se refere ao gênero redação de vestibular, ele se constitui no entremeio de três dimensões ${ }^{14}$ : (1) a escolar, uma avaliação por meio da escrita; (2) a burocrática, em função da necessidade de cumprir um protocolo para acesso ao ensino superior, por meio de uma situação de enunciação bastante restrita; (3) a ficcionalizada, por meio da qual o escrevente constrói imagens de si, diante da ficcionalização de seu outro e de seu papel social. Enquanto as duas

\footnotetext{
${ }^{14}$ Agradeço ao professor Émerson de Pietre a sugestão de trabalhar a redação de vestibular a partir dessas três dimensões.
} 
primeiras dimensões são altamente institucionalizadas, a terceira corresponde à projeção, pelo escrevente, de uma situação representada, da qual ele possa participar como sujeito legítimo. No conjunto, as três dimensões criam um espaço simbólico que dá existência ao gênero redação de vestibular.

\section{B. Objetivos e função social da redação de vestibular}

Apesar de algumas semelhanças entre a redação escolar e a redação de vestibular, esses dois gêneros diferem-se quanto à função social. O objetivo e função social da redação escolar é a verificação do ensino da escrita. Já o objetivo da redação de vestibular é (juntamente com o das demais provas do exame vestibular) permitir ao vestibulando o acesso ao ensino superior, também por meio da verificação do ensino da escrita, mas a de um gênero específico. São gêneros diferentes, com funções sociais distintas e por isso merecem tratamento diferenciado quando analisadas. Vale levantar quais são os critérios para definir quem está apto ou não para acessar o ensino superior, por meio da análise de uma prova de vestibular, incluída nela a prova de redação. Por meio da escrita da redação de vestibular, diferentes competências são analisadas para se tomar essa decisão. Há, nesse sentido, um jogo de poder estabelecido entre o escrevente, que deve provar que possui as competências discursivas necessárias para a aprovação e a banca examinadora, que deve verificar se o candidato realmente possui essas competências. Se a função social da redação de vestibular é a de permitir o acesso ao ensino superior, devem-se levar em conta os aspectos atrelados a essa permissão, como, por exemplo, os critérios de correção da prova de redação. O escrevente, no intuito de querer ser aprovado no exame, deve submeter-se a algumas coerções postas nesta situação de enunciação, sabendo que passará por um processo de julgamento do corretor, com base nesses critérios, que são predeterminados e divulgados no manual do candidato, como se pode conferir, a seguir:

A redação deverá ser, obrigatoriamente, uma dissertação, na qual se espera que 0 candidato demonstre capacidade de mobilizar conhecimentos e opiniões, de argumentar coerentemente e de expressar-se com clareza e adequação gramatical. Na correção da redação, serão examinados três aspectos (Tipo de texto e abordagem do tema, Estrutura e Expressão) sendo que, a cada um deles, poderão ser atribuídos $0,1,2,3$, ou 4 pontos. 
Considera-se aqui se o texto do candidato configura-se como uma dissertação e se atende ao tema proposto. E fundamental, na elaboração do texto dissertativo solicitado, que 0 candidato demonstre a habilidade de ler e articular adequadamente os textos da coletânea para abordar o tema. A elaboração de um texto que não seja dissertativo ou a fuga completa ao tema serão tomadas como pressupostos inquestionáveis para que a prova não seja objeto de correção em qualquer outro de seus aspectos recebendo a nota zero. No que diz respeito ao desenvolvimento, verificar-se-á, além da pertinência na progressão do tema, também a capacidade críticoargumentativa do candidato, bem como a maturidade e a informatividade que no texto manifestam.

\section{2 - Estrutura}

Consideram-se aqui, conjuntamente, os aspectos de coesão textual (Nas frases, períodos e parágrafos) e de coerência de idéias. Maior ou menor coerência reflete a capacidade do candidato em relacionar os argumentos e organizá-los de forma a deles extrair conclusões apropriadas e, também, a habilidade para o planejamento e a construção significativa do texto. Serão considerados aspectos negativos a cópia de trecho da coletânea ou a simples paráfrase, bem como a presença de contradições entre frases ou parágrafo, a falta de encadeamento das idéias, a circularidade ou a quebra de progressão argumentativa, a falta de conclusão ou a presença de conclusões não decorrentes do que foi previamente exposto. Serão tidos também como fatos negativos referentes à coesão, entre outros, o estabelecimento de relações semânticas impróprias entre palavras e expressões, bem como o uso de conectivos.

\section{3 - Expressão}

Consideram-se nesse item o domínio do padrão culto escrito da língua e a clareza na expressão das idéias, serão examinados aspectos gramaticais como ortografia, morfologia, sintaxe e pontuação. A presença de clichês ou frases feitas e, ainda, o uso inadequado de vocábulos serão ocorrências, em princípio, negativas. Espera-se que o candidato revele competência em expor com precisão os argumentos selecionados para a defesa do ponto de vista adotado e demonstre capacidade de escolher e usar expressivamente o vocabulário (FUVEST, 2006, p. 42).

A partir da leitura desses critérios, pode-se afirmar que eles são elementos constitutivos da função social da redação de vestibular, isso porque são objetos de análise para provar ou não a competência do escrevente no que se refere ao gênero estabelecido (com um tipo textual expressamente determinado no manual de instrução, no enunciado da instrução da prova de redação e nos critérios de avaliação divulgados no Manual do candidato); aos elementos estruturais do texto, como, coesão, coerência e capacidade argumentativa e ao domínio da língua escrita culta. 
Longe de considerar a escrita da redação de vestibular apenas uma atividade de cunho escolar, é necessário dizer o motivo pelo qual a considero uma prática social. Uma prática que leva em conta a elaboração de um texto em situação de uso concreto da língua, que considera a escrita como constitutivamente dialógica e por isso heterogênea. Além disso, por ser dialógica, é igualmente responsiva. Responde aos enunciados da prova de redação, aos critérios de correção dessa prova, aos interlocutores e a enunciados presentes em sua memória discursiva.

$\mathrm{Na}$ perspectiva adotada para a pesquisa, tomo a análise da escrita por meio de um gênero discursivo, o que pressupõe uma análise dos enunciados das redações que busca posições ideológicas inscritas nessa prática social, que busca os lugares sociais de quem enuncia: quem fala? fala de onde? como fala? para quem fala? por que fala? Esses lugares são construídos no texto enquanto discurso; enquanto vozes que se colocam, enquanto PDVs construídos pelo escrevente, que deixa suas marcas inscritas nos enunciados das redações, o que permite aprofundar o estudo da escrita e das representações do escrevente.

Diante da consideração do gênero redação de vestibular como uma prática social e discursiva, com função social específica, particularizo, a seguir, a discussão desse gênero, situando-o em sua dimensão textual e enunciativo-discursiva.

\subsection{A redação de vestibular e sua dimensão textual e enunciativo-discursiva}

Partindo da concepção de escrita como prática discursiva, busco explicitar a configuração do gênero redação de vestibular a partir das dimensões que o compõem: a textual e a enunciativo-discursiva. Tendo como objeto de pesquisa a construção de PDVs na organização do texto, estabeleço as bases teóricas que aportam essas duas dimensões.

No que se refere à dimensão textual, examino o tipo textual que, em parte, é responsável pela configuração da estrutura composicional do gênero redação de vestibular. A estrutura composicional poderia, também, ser tomada como esquema textual, não do ponto de vista cognitivista, mas do ponto de vista discursivo, em que a estrutura textual é resultado (1) das representações que o escrevente tem da escrita e do gênero e, (2) de suas práticas letradas, atualizadas no acontecimento 
discursivo. Na concepção bakhtiniana de gênero, a estrutura composicional reflete a situação de enunciação, daí ser o gênero relativamente estável. É estável no reconhecimento, caso contrário, segundo Bakhtin (2003), teria de ser criado a cada nova comunicação. E sua estabilidade é, no entanto, relativa porque está ligada à singularidade do escrevente e da própria situação de enunciação em que 0 escrevente se apresenta e se constrói na relação com o outro. Assim, não se pode dizer que há uma estrutura fixa, congelada, mas que ela é reconhecida no seio do próprio gênero, em função das práticas letradas e das representações do escrevente, atualizadas no acontecimento discursivo. Estão em jogo, assim, não só o conhecimento linguístico, enciclopédico e genérico do escrevente, mas o modo como se podem materializar linguisticamente esses conhecimentos na situação de enunciação do exame de redação.

$\mathrm{Na}$ elaboração do gênero redação de vestibular, o tipo textual dissertativoargumentativo é configurado em função de seus aspectos linguísticos, naquilo que se convencionou chamar de um texto argumentativo para este modelo de redação de vestibular, mas também no âmbito estilístico do escrevente. Quando, num enunciado de redação, o esquema textual está fortemente marcado, pode-se dizer que esse escrevente domina os modelos considerados mais adequados, segundo o discurso pedagógico em que se prioriza a estabilidade do gênero e não os elementos do acontecimento discursivo, tais como: leitor presumido, função e objetivo do gênero numa situação de comunicação avaliativa, isto é, um contexto sociocultural bastante conhecido e explorado no ambiente escolar.

Estudar a construção de PDVs envolve estudar a organização argumentativa interna ao texto, isto é, trabalhar os aspectos argumentativos do gênero. Destaco, desse item, a importância da noção do tipo textual e a expressão argumentativa que compõem a redação de vestibular, não estritamente no que se refere à persuasão pelo conteúdo temático, mas principalmente pela situação de enunciação, em que o escrevente deve mais mostrar que sabe escrever tal gênero do que persuadir o leitor a acatar o PDV defendido. São aspectos salientes para abordar a organização textual da construção de PDVs, numa situação tão singular como a da elaboração da redação de vestibular.

Abordar o texto tendo como parâmetro a definição de gênero discursivo é fator imprescindível extrapolar seus aspectos textuais, sem abandoná-los. O gênero 
redação de vestibular será abordado, assim, sob a heterogeneidade que the é constitutiva, lançando mão de aspectos enunciativos e discursivos que todo gênero comporta. Para isso, abrigo-me nos estudos da teoria da enunciação baseada, principalmente, nos estudos do círculo bakhtiniano, mas igualmente estudos que trazem noções da Análise do Discurso, fundamentais para depreender o modo de construção de PDVs na organização do texto.

\subsection{A dimensão textual}

Dentre os trabalhos pesquisados sobre redação de vestibular do tipo considerado em sua predominância dissertativo, não há consenso no que se refere à definição do seu tipo textual, haja vista a própria confusão entre os termos tipo e gênero, quando o assunto é redação de vestibular. Conforme dito na introdução, considero a redação de vestibular um gênero que, no vestibular que analiso, apresenta como tipo textual predominante o dissertativo-argumentativo. A organização textual da redação de vestibular remonta características da retórica argumentativa: exórdio (proêmio), proposição (exposição), argumentação (provas, refutação) e peroração (epílogo). Essa organização remete a aspectos bastante recorrentes no ensino desse gênero: a introdução, o desenvolvimento e a conclusão, aspectos que consideram a estrutura temática primordial em detrimento de aspectos discursivos. A redação é ensinada por meio de técnicas e de treino de estruturas, tendo como guia a construção de esquemas caracterizados em função da organização textual dos parágrafos

Os enunciados das redações do corpus apresentam, em sua maioria, a introdução, geralmente em um parágrafo; seguida do desenvolvimento, em sua maioria com dois ou três parágrafos e, fechando o texto, um parágrafo conclusivo. Quanto ao número de parágrafos, sintetizei, na Tabela 1, a organização das redações e suas respectivas quantidades de parágrafos: 
Tabela 1: quantidade de parágrafos nas redações

\begin{tabular}{|c|c|c|}
\hline № de parágrafos & $\begin{array}{c}\text { Quantidade de } \\
\text { Redações }\end{array}$ & $\%$ \\
\hline 03 & 16 & 5,9 \\
\hline 04 & 98 & 36,6 \\
\hline 05 & 107 & 39,6 \\
\hline 06 & 27 & 10,0 \\
\hline 07 & 15 & 5,5 \\
\hline 08 & 4 & 1,4 \\
\hline 09 & 2 & 0.7 \\
\hline 10 & 1 & 0,3 \\
\hline Total & 270 & 100 \\
\hline
\end{tabular}

Como se pode observar, a Tabela 1 mostra que, ao menos na amostra aleatória que nos foi fornecida, em sua maioria, as redações estão organizadas estruturalmente em 4 ou 5 parágrafos. É bom lembrar que uma das recomendações dos manuais de redação refere-se ao número de parágrafos, sendo indicado, de preferência, que a redação seja elaborada em 4 ou 5 parágrafos (1 introdutório, 2 ou 3 para o desenvolvimento e 1 para a conclusão), mesmo porque o espaço destinado para a elaboração da redação no exame - trinta e quatro linhas - não possibilita um texto muito longo, com parágrafos maiores do que seis linhas.

Ao organizar os parágrafos - aspecto textual - o escrevente interage com o contexto de produção - aspectos extratextuais da redação de vestibular. O escrevente responde ao comando que the é dado: escrever um gênero específico. Responde em concordância com seu conhecimento sobre o gênero, não só enquanto esquema textual, mas principalmente por suas representações. Além disso, há influências das representações do próprio exame. Não é, então, a língua enquanto estrutura que faz com que o escrevente componha uma redação com um número " $x$ " de parágrafos, mas o uso concreto da língua, que envolve todo o processo de produção desse gênero. Pode-se enumerar, por exemplo, tudo aquilo que o escrevente já ouviu de seus professores, tudo o que já leu sobre o assunto e mesmo suas escritas anteriores desse mesmo gênero. A partir desse conhecimento prévio, o escrevente constrói suas representações e redige seu texto com base nele. 
$\mathrm{Na}$ organização de cada parágrafo também é possível reconhecer a presença, nos enunciados das redações, de esquemas textuais como resultado do diálogo do escrevente com o que Corrêa chama de "código institucionalizado" em que se faz presente 0

caráter reprodutor de uma prática instituída; a tentativa de alçamento à escrita culta formal e aos discursos estabilizados da instituição escolar; a auto-atribuição de uma posição, tendo em vista a suposição de lugares específicos para o letrado/escrito, tidos como institucionalmente definidos; a auto-atribuição de uma posição, em relação à posição atribuída ao interlocutor [...] (CORREA, 2004, p. 167).

O ensino de redação na escola se dá por meio de orientações básicas e de técnicas apresentadas como ajuda metodológica. As orientações gerais consistem em apresentar dicas que o escrevente deve acatar para "ir bem na redação", tais como: não usar a primeira pessoa, ou seja, ser impessoal; evitar o uso de certas expressões (clichês); de certos advérbios (sempre, nunca) ou de generalizações (todos, a humanidade, o mundo, as pessoas); explicitar um posicionamento por meio do uso de argumentos; etc. As técnicas podem ser treinadas pelos escreventes, a partir de determinado tema, quase sempre na ordem: entender o tema e buscar as ideias ligadas a esse tema; diante dessas ideias, buscar argumentos a favor (aspectos positivos) e argumentos contra (aspectos negativos), separando-os e classificando-os e, a partir deles, construir frases concisas; colocar em uma ordem coerente e acrescentar os conectores apropriados - de adição, de oposição, de concordância -; dispor as frases em parágrafos organizados em introdução, desenvolvimento e conclusão (resumo das ideias expostas/dos aspectos apresentados. Esse roteiro é o modelo dominante; porém, existem outras dicas, como: transformar o tema em uma pergunta e, em seguida, tentar responder a essa pergunta, concordando ou discordando. O passo seguinte é escolher a melhor resposta e procurar seu fundamento. Essa é uma estratégia para encontrar o argumento principal que será utilizado na elaboração da redação. De posse do argumento principal, deve-se recorrer a elementos que complementem o argumento principal, que podem vir acompanhados de exemplos, como um fato histórico. E, enfim, organizá-los na forma de um texto. Sintetizando, tem-se o seguinte esquema: interrogar o tema, responder com a opinião, apresentar argumentos básico (tese) e auxiliares, inserir exemplos e concluir (cf. AMARAL, 1991). 
Além desses aspectos, há também o caráter argumentativo exigido para a redação de vestibular e, nesse sentido, a formulação do posicionamento do escrevente. Os aspectos que acabo de mencionar são lugares privilegiados para o encontro com o modo como o escrevente constrói PDVs na organização do texto, bem como para o desvelamento e a materialização linguística de suas representações, seja da escrita, de si, do outro e do próprio tema abordado.

Inúmeros manuais de redação e muitas páginas veiculadas na internet têm dado orientações sobre como redigir uma boa redação no exame vestibular. Esses manuais estão, em geral, divididos em partes que correspondem a tipos textuais de redação - narração, descrição, carta argumentativa e dissertação. Apesar dessa variedade, as orientações enfatizam o ensino da redação de vestibular enquanto dissertação, uma vez que é a mais solicitada nos exames vestibulares das universidades brasileiras, como é o caso do exame da FUVEST. Esse fato revela que tanto a instituição universitária quanto o presumido social exigem a verificação dessa competência - a de saber redigir um texto dissertativo-argumentativo - por valorizá-la no sentido de ela permitir ao escrevente manifestar-se criticamente.

$\mathrm{Na}$ totalidade do corpus analisado, pude observar a presença de diferentes esquemas textuais, alguns mais explícitos, bem marcados; outros mais diluídos, mas, de modo geral, sempre perceptíveis aos olhos do analista. Farei referência a eles no momento da análise. Seguir modelos de escrita é uma tendência que cresce em muitos sistemas de ensino, por exemplo, por meio do aumento do número de escolas, não só particulares, que adotam o ensino apostilado. Apesar de divulgado como material de apoio, a intenção, creio, é propagar o modelo apostilado. Esse tipo de material teria seus benefícios, principalmente no que se refere ao trabalho com textos mais longos e na falta de recursos para que cada aluno tenha o material a ser trabalhado em mãos; entretanto, não pode ser o único material a ser utilizado. Isso feriria a própria heterogeneidade da vida em sociedade, além do mais, cada sala de aula é um contexto específico. O ensino da escrita nessa perspectiva rígida deixa de considerar a dimensão sociocultural que envolve a escrita de um gênero, por isso, talvez, se autoriza a considerar apenas o tipo de texto, resolvendo a problemática da escrita com esquemas prontos.

Para firmar esse meu posicionamento crítico, diferencio as expressões "tipo textual" e "gênero discursivo". Reafirmo, em primeiro lugar, que assumo a redação 
de vestibular como gênero do discurso. Na produção desse gênero no vestibular da FUVEST, é, por sua vez, requerido o tipo textual dissertativo-argumentativo. Para deixar clara essa distinção, explico-a, com mais detalhes, na sequência.

De acordo com Marcuschi (2002), a expressão tipo de texto vem sendo empregada erroneamente, quando a utilizam para designar um gênero, por exemplo, a carta pessoal ou a bula de remédio ${ }^{15}$.

A expressão tipo de texto está diretamente relacionada com a natureza linguística do texto, isto equivale a dizer que está ligada aos elementos textuais do gênero, organizados em sequências linguísticas. É a partir dessa organização que eles são classificados. Apesar da natureza linguística específica e que pode ser identificada no texto, os tipos também podem apresentar certa heterogeneidade em sua formulação, pois o que caracteriza os tipos textuais é a natureza da sua organização no texto, bem como suas funções, por exemplo, narrar uma história e descrever o local de um acontecimento, ambos inseridos em um gênero cujo tipo textual é, por exemplo, o argumentativo. Essas sequências são estereotipadas e marcadas por "constructos teóricos definidos por propriedades linguísticas" (MARCUSCHI, 2002, p. 23). São os elementos textuais que determinam os diferentes tipos de textos. A classificação de tipos de textos tem variação de autor para autor, como podemos observar no quadro 1, na página seguinte:

${ }^{15} \mathrm{O}$ autor distingue tipo e gênero textual, propondo a distinção exposta no quadro abaixo. Note-se que, por sua vez, o autor não diferencia gênero textual de gênero do discurso, num recurso de adaptação da formulação bakhtiniana ao âmbito da Linguística Textual.

\begin{tabular}{|c|c|}
\hline Tipos Textuais & Gêneros Textuais \\
\hline $\begin{array}{l}\text { 1. constructos teóricos definidos por } \\
\text { propriedades linguísticas intrínsecas; }\end{array}$ & $\begin{array}{l}\text { 1. realizações linguísticas concretas } \\
\text { definidas por propriedades sócio- } \\
\text { comunicativas; }\end{array}$ \\
\hline $\begin{array}{l}\text { 2. constituem sequências linguísticas ou } \\
\text { sequências de enunciados no interior dos } \\
\text { gêneros e não são textos empíricos; }\end{array}$ & $\begin{array}{l}\text { 2. constituem textos empiricamente } \\
\text { realizados cumprindo funções em } \\
\text { situações comunicativas; }\end{array}$ \\
\hline $\begin{array}{l}\text { 3. sua nomeação abrange um conjunto } \\
\text { limitado de categorias teóricas determinadas } \\
\text { por aspectos lexicais, sintáticos, relações } \\
\text { lógicas, tempo, verbal; }\end{array}$ & $\begin{array}{l}\text { 3. sua nomeação abrange um } \\
\text { conjunto aberto e praticamente } \\
\text { ilimitado de designações concretas } \\
\text { determinadas pelo canal, estilo, } \\
\text { conteúdo, composição e função; }\end{array}$ \\
\hline $\begin{array}{l}\text { 4. designações teóricas dos tipos: narração, } \\
\text { argumentação, descrição, injunção e } \\
\text { exposição. }\end{array}$ & $\begin{array}{l}\text { 4. exemplos de gêneros: telefonema, } \\
\text { sermão, carta comercial, carta } \\
\text { pessoal, romance, bilhete [...], etc. }\end{array}$ \\
\hline
\end{tabular}

(Fonte: MARCUSCHI, 2002, p.23) 
Quadro 1: Autores / Tipos de texto

\begin{tabular}{|l|l||}
\hline \hline AUTORES & ASPECTOS TIPOLÓGICOS / TIPOS DE TEXTO \\
\hline Dolz; Schneuwly (2004) & Narrar, relatar, argumentar, expor, descrever ações. \\
\hline Marcuschi (2002) & Narrativo, descritivo, argumentativo, expositivo, injuntivo. \\
\hline Adam (1992) & $\begin{array}{l}\text { Sequências narrativa, descritiva, argumentativa, explicativa, } \\
\text { dialogal. }\end{array}$ \\
\hline
\end{tabular}

Como se pode perceber, não há consenso entre os estudiosos sobre os diferentes tipos de texto. Os tipos de texto variam em quantidade e em tipos propriamente dito. Há os três clássicos (narração, descrição, argumentação) que estão presentes nos autores citados e os não coincidentes, como os tipos explicativo, expositivo, dialogal e injuntivo. Outra diferença observada refere-se ao tipo dialogal - que se refere ao diálogo mesmo - e o tipo injuntivo, relativo ao modo imperativo constante em manuais de instrução, por exemplo. Adam (1992, p. 140) organiza sua classificação das sequências a partir do que define por superestruturas textuais, que para ele são esquemas prototípicos, que operam na distinção entre dimensão textual e sequencial. Em função dessa distinção, ele classifica os textos em tipos de sequências.

Há diferentes definições e classificações para o termo dissertação. Lembrando que, muitas vezes, esse termo é usado como nome do gênero, tendo como tipo de texto o argumentativo, vale mostrar como essa distinção está presente em diferentes autores. Para alguns autores, há vários tipos de dissertação. Santaella (2005, p. 339ss), por exemplo, diferencia-a em três modalidades, a conjectural, dotada do raciocínio abdutivo; a relacional, em que há comentários de fatos, exemplificações e generalizações e a dissertação argumentativa, em que o discurso está ligado aos mecanismos do raciocínio dedutivo. A autora classifica a dissertação argumentativa em várias submodalidades, como opinativa, comparativa, interpretativa. Fávero e Koch (1983) classificam o texto dissertativo como expositivo ou explicativo, sendo esses dois termos sinônimos. Já para Travaglia (1991), esses dois termos - expositivo e explicativo - referem-se à subdivisão do tipo textual dissertativo, que ele chama subtipo e, nesse caso, não são sinônimos. Esse autor também diferencia argumentação de dissertação. Todavia, há autores que não

\footnotetext{
${ }^{16}$ Os autores tratam dessas tipologias em sua relação com capacidades de linguagem dominantes, para o trabalho com o ensino de gêneros agrupados (DOLZ; SCHNEWLY, 2004, p. 60).
} 
fazem essa distinção; é o caso de Citelli (1994), que usa indiferentemente os dois termos.

O tipo dissertativo tem sua tessitura textual heterogênea, apresentando, por exemplo, características descritivas e narrativas ${ }^{17}$. Essa variedade de tipos que podem compor uma dissertação levou-me a considerar o tipo textual do gênero redação de vestibular produzido no exame da FUVEST como dissertativoargumentativo. Dissertativo porque o escrevente deve, necessariamente, dissertar sobre o tema dado. Nesse dissertar, o escrevente vai tratar do objeto de discurso, seja ele qual for, em vários aspectos de sua constituição, tendendo ora para a definição, ora para o seu funcionamento, ora para a descrição, ora para a narração de fatos, tomados estes últimos como argumentos para a construção daquele objeto de discurso, etc. No que se refere ao argumentativo, o escrevente buscará explicálo, avaliá-lo, perpetrando um julgamento de valor sobre esse objeto, para tomar seu posicionamento enunciativo.

Inserido no estudo dos tipos de texto, o dissertativo-argumentativo ${ }^{18}$ é o tipo privilegiado no exame da FUVEST e será nele que me deterei, a fim de descrevê-lo em suas propriedades linguísticas, por meio dos aspectos lexicais e sintáticos, da constituição de suas sequências textuais, sem perder de vista o gênero discursivo objeto da pesquisa. Classifico como dissertativo-argumentativo o tipo de texto da redação de vestibular da FUVEST porque o escrevente deve, necessariamente, dissertar sobre determinado tema, no caso, o trabalho, e argumentar a favor de determinado posicionamento a respeito desse mesmo tema. Considerando a heterogeneidade dos tipos textuais, o tipo dissertativo-argumentativo será tratado em suas características essenciais, a saber, a dissertação, por meio da qual se expõe determinado tema, no caso desta pesquisa, o trabalho; e a argumentação, com que se constroem argumentos para aceitar ou refutar ideias, como também para convencer ou persuadir o leitor da posição que se está defendendo. Ambas as características constituem o gênero redação de vestibular.

\footnotetext{
${ }^{17}$ Soster (2009) constata, em sua pesquisa, a presença marcante, na redação de vestibular, de elementos da narração. Por meio do estudo das temporalidades, o pesquisador detecta sequências narrativas determinantes desse gênero.

${ }_{18}$ Muitos autores tomam como estudo, no que se refere à redação de vestibular, apenas a argumentação. Quando digo tipo de texto dissertativo-argumentativo refiro-me ao tipo textual privilegiado pelo gênero redação de vestibular no exame da FUVEST.
} 
A escolha de apenas um dos termos - dissertativo ou argumentativo - talvez esteja relacionada a um olhar unilateral para o tipo de texto da redação de vestibular. Certamente está, também, relacionada à concepção do que é dissertar e argumentar. Dissertar, segundo o dicionário eletrônico Houaiss (HOUAISS; VILLAR, 2002), é "expor algum assunto de modo sistemático, abrangente e profundo, oralmente ou por escrito". Há autores que acrescentam aspectos argumentativos em sua definição:

dissertação implica discussão de idéias, argumentação, raciocínio, organização do pensamento, defesa de pontos de vista, descoberta de soluções. Significa refletir sobre nós mesmos e sobre o mundo que nos cerca [...] O texto dissertativo é aquele que expressa uma tese (o que se quer provar), um ponto de vista sobre determinado assunto, apoiado em dados, fatos, argumentos (PACHECO, 1988, p. 1 , grifos do autor).

Já para Grataloup (1990, p. 89-90) ${ }^{19}$, em trabalho sobre a filosofia e a prova de dissertação, dissertar é:

colocar um problema em suas múltiplas composições, afirmar e desmontar teses, Ihes interrogar sobre seus pressupostos e suas implicações, fazer objeções, responder às objeções, fazer intervir autores filosóficos nesse debate, integrá-los numa "reflexão pessoal" $[\ldots]$.

Pode-se observar que, para Grataloup, dissertar é muito mais do que expor algo sobre determinado tema. Nesse sentido, dissertar está mais próximo do que normalmente se define como argumentação. Segundo o dicionário eletrônico Houaiss (2002), argumentar é "apresentar fatos, idéias, razões lógicas, provas etc. que comprovem uma afirmação, uma tese; [...] apresentar idéias em objeção a outras idéias; [...] tirar conclusões [...]". Como se vê, embora haja diferentes acepções para os termos "dissertar" e "argumentar", podem-se observar, também, pontos de intersecção entre elas (por exemplo, "expor idéias" - dissertação - e "apresentar idéias" - argumentação).

Interessa-me destacar que o estudo da escrita na perspectiva do gênero pede uma concepção de texto como atividade argumentativa, em que o escrevente opera segundo determinadas estratégias para defender certo posicionamento. No gênero redação de vestibular, o escrevente parte de determinado tema dado para dissertar

${ }^{19}$ As traduções de texto não publicados em português são de minha responsabilidade. 
sobre ele, assumindo posicionamentos enunciativos, fazendo asserções e objeções, argumentando a respeito delas. O tipo de texto dissertativo-argumentativo é, por excelência, um tipo heterogêneo em que estão presentes outros tipos de texto, como os citados no Quadro 1. Para elaborar o gênero redação de vestibular é necessário, além de dissertar e argumentar sobre determinado assunto, descrever fatos, relatar eventos, para chegar à conclusão desejada sobre determinada visão do tema. Esses diferentes tipos de texto podem, portanto, compor o tipo de texto encontrado na redação de vestibular e, por meio de operações de combinações linguísticodiscursivas de suas sequências textuais, constituir o arcabouço argumentativo para construir determinado PDV. É sobre esse arcabouço que vou tratar a seguir, com o objetivo de demarcar, ainda mais detalhadamente, o que entendo por argumentação, aspecto fundamental da redação de vestibular.

Há teóricos que defendem que o princípio do texto argumentativo é chegar à determinada conclusão, por meio de argumentos convincentes. Toulmin (1993), por exemplo, afirma que, além dessa orientação para determinada conclusão, para se chegar a ela é preciso ter garantias e referências fortes que são constituídas por meio de qualificadores modais. Segundo o que penso, estes qualificadores modais estabelecem movimentos argumentativos no texto, movimentos que vão conduzir (ou não!) a orientação para certa conclusão.

Anscombre e Ducrot (1983) tomam o texto argumentativo sob dois pontos: o de partida e o de chegada, a eles está ligado o sentido do enunciado que é guiado pelo argumento em direção a uma conclusão. Os autores elaboraram essa teoria por meio do estudo dos conectores, em que estudam a (1) orientação argumentativa do enunciado; (2) a força argumentativa: conectores lógicos ou pragmáticos e (3) a contradição argumentativa: enunciado coorientado versus antiorientado. Para esses autores, então, a argumentação é construída por meio de movimentos argumentativos organizados a partir dos conectores presentes no texto. Os autores afirmam que são os conectores argumentativos os responsáveis pela orientação dos enunciados na direção de uma conclusão $R$. Os argumentos se caracterizam conforme sua força, organizada em uma hierarquia. A argumentação consiste, então, na relação entre argumentos organizados hierarquicamente e conclusão. É dessa relação que se estabelece a valoração argumentativa dos enunciados, que estão dispostos numa escala argumentativa em função de cada argumento. 
O valor argumentativo do enunciado é, pois, determinado por sua orientação argumentativa que, por sua vez, é determinada pelos conectores, que os autores chamam de argumentativos. No caso dos textos analisados, por meio desses conectores, o escrevente pode impor uma direção argumentativa em seu texto, dispondo os argumentos numa relação de interdependência, a fim de fazer o leitor chegar a certa conclusão. A conclusão é formulada em função do interlocutor e da situação de enunciação. O valor argumentativo do enunciado é indicado pelo valor argumentativo da enunciação. Assim, na redação de vestibular, a força argumentativa do enunciado está diretamente ligada à situação de avaliação a que o escrevente está submetido, o exame vestibular. O movimento textual argumentativo se dá no enunciado, mas é moldado pela enunciação. Os movimentos argumentativos, então, vão se desdobrar em movimentos discursivos em função da situação de enunciação. Há, nesse sentido, um jogo entre o que é interno ao enunciado e o que é externo a ele, realizando mudanças de um estado a outro, isto é, o movimento argumentativo vai se desdobrar em movimento discursivo.

De acordo com Vigner (1990, p. 41ss), a dissertação deve organizar-se de um estado a outro $(\mathrm{E} 1 \rightarrow \mathrm{E} 2)$, realizando um movimento argumentativo global por meio da seleção de conectores que definem a orientação e a força da argumentação. Esse movimento é gerenciado discursivamente segundo uma valorização do objeto do discurso. Para o autor, há três possibilidades de movimentos: de aprovação, de refutação e de concessão. No movimento de aprovação não há efetivamente uma mudança de estado, mas um reforço do estado inicial. No movimento de refutação há uma mudança total dos estados, sendo E1 totalmente diferente de E2. E no movimento de concessão ocorre uma mudança parcial entre os estados.

Destaque-se que cada um desses movimentos se dá em função do posicionamento que o escrevente quer evidenciar em seu texto, na relação com outros posicionamentos. Esse posicionamento se caracteriza linguisticamente pelas escolhas lexicais que vão manifestar o julgamento do escrevente diante do objeto do discurso, como mostrarei mais detalhadamente na análise dos elementos qualificadores das redações.

No que se refere à redação de vestibular, a presença do movimento de aprovação pode dar-se de duas maneiras: na concordância do escrevente com um ou mais textos da coletânea e/ou na defesa de uma visão sobre o trabalho não 
estabelecida pela coletânea. Da mesma forma, no movimento de refutação, o escrevente pode refutar um ou mais textos da coletânea ou refutar uma visão do trabalho não estabelecida pela coletânea. Outra forma de se apresentar o movimento argumentativo na redação é pelo movimento de concessão, em que o escrevente concorda apenas parcial e estrategicamente com os textos da coletânea.

São esses movimentos que caracterizam a orientação argumentativa do enunciado. Concomitantemente a essa orientação está a valoração do enunciado. Momento em que o escrevente anuncia o julgamento sobre o objeto de discurso, manifestando o seu posicionamento diante do tema dado. Essa manifestação se caracteriza sob determinados valores que se movimentam ora positiva ora negativamente em relação ao tema dado, o trabalho. Interessa-me saber como o escrevente constrói os movimentos que implicam uma avaliação da propriedade do objeto do discurso, nos quais se explicitam suas representações diante do tema dado, bem como as representações que tem de seu interlocutor e da própria escrita.

$\mathrm{Na}$ retórica clássica, o texto argumentativo visava persuadir um auditório. Os gêneros se distinguiam em deliberativo, judiciário e epidídico (demonstrativo), porém, na forma de discurso oral. A organização desse discurso, de acordo com Perelman (2004) era: Invention, que tratava da etapa argumentativa em que consistia em encontrar os argumentos; disposition, que organizava esses argumentos, chamada de etapa textual; élocution, que se refere à etapa linguística, consistia em dispor os argumentos na forma discursiva. Assim se justificam as duas etapas posteriores, memorização e ação, em que se dava a apresentação do discurso argumentado a um auditório ${ }^{20}$. É possível depreender esse fazer discursivo da élocution nas redações na responsividade de seus enunciados, isto é, na relação dialógica do escrevente com seu interlocutor.

A presença inerente de um interlocutor para a apresentação do texto argumentativo leva a apreender que o modo de argumentar é indissociável da situação de enunciação. Diante de um texto argumentativo, perguntar-se como a enunciação permite saber quem é o enunciador, quem é o enunciatário e em quais

${ }^{20}$ Cabe um esclarecimento: Perelman e Olbrechts-Tyteca, ao tratarem da argumentação, não distinguem o discurso oral do escrito: "quando utilizarmos os termos 'discurso', 'orador' e 'auditório', entenderemos com isso [respectivamente] a argumentação, aquele que a apresenta e aqueles a quem ela se dirige, sem nos determos no fato de que se trata de uma apresentação pela palavra ou pela escrita" (PERELMAN \& OLBRECHTS-TYTECA, 2005, p. 7). 
circunstâncias o enunciado foi produzido. Ou seja, a enunciação depende diretamente da situação na qual o enunciado foi produzido. Essa situação interfere igualmente na construção dos argumentos de que o enunciador se utiliza para convencer seu interlocutor de algo, pois deve "pensar nos argumentos que podem influenciar seu interlocutor, preocupar-se com ele, interessar por seu estado de espírito" (PERELMAN \& OLBRECHTS-TYTECA, 2005, p. 18).

A argumentação visa a convencer ou a persuadir, de acordo, respectivamente, com o objetivo do orador de alcançar o auditório universal ou um auditório particular. É, no entanto, o modo de fazê-lo que me interessa, ou seja, a maneira como o escrevente apresenta e dispõe os argumentos, uma vez que para isso ele terá de manifestar seu posicionamento, seus julgamentos diante de fatos da realidade, etc. Terá de ser eficiente na elaboração de seus argumentos, que se faz em função do interlocutor. A argumentação se dá em relação direta com o seu interlocutor. O texto argumentativo é aquele destinado a convencer tanto pelo conteúdo de suas ideias quanto por seus argumentos. Os argumentos devem estar organizados e articulados entre si, a fim de desenvolver coerentemente a tese a ser defendida. A ideia matriz é guiada pelo movimento argumentativo estabelecido pelo escrevente. Esse movimento argumentativo é construído por determinadas estratégias constituídas por pistas linguísticas que direcionam a argumentação. Busco essas estratégias por meio da observação e análise do uso dos qualificadores no texto. O enunciador está inscrito no enunciado por meio de marcas linguísticas, por exemplo, a adjetivação ou a modalização que reforçam um julgamento e uma tomada de posição.

Classificar a composição da redação de vestibular como um texto dissertativoargumentativo permitirá analisá-la em seus componentes textuais constitutivos. A estrutura da argumentação é estereotipada na concepção do escrevente e, quando bem organizada textualmente, é facilmente identificada pelo analista. Segundo Perelman \& Olbrechts-Tyteca (2005, p. 581), é graças à possibilidade que o escrevente tem de fazer escolhas e de argumentar que é possível fazer com que os leitores acatem as suas posições e decisões. Desse modo, interessa-me investigar não só os efeitos sobre o interlocutor, mas as estratégias argumentativas utilizadas pelo escrevente para chegar a esse objetivo. 
A intenção em tratar separadamente a dimensão textual, neste momento, foi a de destacar a organização mais formal do texto. Falta responder de que modo esse aspecto textual se articula com o enunciativo-discurso. É no que me deterei no próximo item.

\subsection{A dimensão enunciativo-discursiva}

Situar a redação de vestibular na dimensão enunciativo-discursiva é, como ficou dito, considerá-la portadora de diferentes enunciadores, de diferentes posições enunciativas derivadas de lugares sociais, bem como portadora de diferentes discursos num contexto histórico determinado.

A perspectiva enunciativa deve dar conta de elementos da enunciação a partir dos enunciados das redações, de tal modo que possa, então, alçar-se aos desdobramentos discursivos nelas presentes. Estes envolvem a ocupação de determinada posição por parte do escrevente, a partir da qual ele assume determinados posicionamentos, opõe PDVs e estabelece PDVDs.

De acordo com a teoria polifônica de Ducrot (1987), o enunciado é o lugar da manifestação da frase, é uma parte da enunciação (p. 177). A enunciação "é o acontecimento constituído pelo aparecimento de um enunciado. A realização de um enunciado é de fato um acontecimento histórico" (DUCROT, 1987 p. 168). Se é histórico, é um acontecimento único e irrepetível.

Destacam-se, nessa visão da relação entre enunciação e enunciado, as noções de locutor e enunciador.

\section{A. Enunciado e enunciação}

Na teoria de Ducrot (1987), é fundamental compreender as noções de locutor e enunciador. A noção de Locutor, em Ducrot (1987), está organizada em três dimensões, o sujeito empírico - o falante -; o locutor enquanto ser do mundo $(\lambda)$ - 0 responsável pelo dizer, responsável pela enunciação, fonte do discurso - e o locutor como tal (L), a ficção discursiva ou ser do discurso, a ele se referem as marcas de primeira pessoa do discurso. A teoria de Ducrot também diferencia o locutor $(L)$ do enunciador (E). Este, na teoria polifônica, é a origem das posições tomadas no fio do discurso, é a expressão do PDV, ou seja, é aquele que dá orientação argumentativa 
ao enunciado. Ducrot não se refere a apenas um enunciador, uma vez que sua teoria contesta a unicidade do sujeito (se opondo, quanto a isso, a Benveniste), mas a vários enunciadores postos em cena pelo locutor, exatamente para compor uma argumentação direcionada por meio de posicionamentos. Assim, para o autor, Enunciadores são as vozes do enunciado, que também constituem o seu sentido:

o sentido do enunciado, na representação que ele dá da enunciação, pode fazer surgir aí vozes que não são as de um locutor. Chamo "enunciadores" estes seres que são considerados como se expressando através da enunciação, sem que para tanto se lhe atribuam palavras precisas; se eles 'falam' é somente no sentido em que a enunciação é vista como expressando seu ponto de vista, sua posição, sua atitude, mas não, no sentido material do termo, suas palavras (DUCROT, 1987, p. 192).

É esse sentido que busco em Ducrot: os enunciadores são os PDVs representados no enunciado e é o locutor o responsável por organizar essas vozes. Para o autor, Locutor é também aquele que se responsabiliza pelo dizer: "alguém a quem se deve imputar a responsabilidade deste enunciado" (op. cit., p. 182). Esse locutor assume, em seu enunciado, posições enunciativas que se desdobram em movimentos discursivos. A polifonia linguística em que o autor distingue enunciado de enunciação, isto é, o dito e o dizer, remete à discussão das funções enunciativas e discursivas marcadas no enunciado. Trata-se, nesse sentido, de olhar não para o que o locutor diz, mas para o modo como ele diz o que diz. Trata-se de observar sua percepção sobre determinado objeto e como a argumentação é construída sob esse olhar.

Uma ressalva é importante quanto ao que o autor afirma sobre o sentido do enunciado: Ducrot, diferentemente de minha posição, deixa de fora da construção do sentido a alteridade, o outro. Para ele, o sentido é posto no próprio enunciado, assim como afirma que a argumentação está na língua. $O$ que, a meu ver, transparece nessas afirmações é a negação da historicidade, elemento importante da constituição de um gênero e da construção de sentidos do enunciado, que acontecem exatamente no espaço de interação em que os sujeitos, o um e o outro, se constituem. Dessa interação nasce o caráter responsivo-ativo de todo enunciado (BAKHTIN, 2003), forma de se retomar o processo sócio-histórico de constituição de todo gênero. 
Destaco, de Ducrot (1987), os conceitos de locutor e de enunciador, bem como a hierarquização de enunciadores introduzidos no enunciado pelo locutor, relacionado ao mecanismo da autoridade polifônica, isto é, um locutor põe em cena, no discurso, PDVs que podem ser tanto dele próprio quanto de outros: enunciadores ou o do próprio alocutário. Como disse anteriormente, o autor diferencia locutor em três dimensões: o sujeito falante, o locutor como tal e o locutor como ser do mundo. Ducrot não se detém na primeira dimensão, a do sujeito empírico, ele centraliza a sua discussão na distinção entre locutor como tal e locutor ser do mundo. Essas distinções são tomadas no próprio enunciado, o que equivale a dizer que elas não dizem respeito ao exterior do enunciado, ou seja, ao extralinguístico; o autor se prende aos aspectos internos ao enunciado.

Vale salientar, uma vez mais, que se tomo como uma das bases de análise a perspectiva enunciativa, não posso conceber o enunciado como neutro, porque ele se constitui na relação com a enunciação e por meio de um gênero discursivo. Nesse sentido, concebo o PDV como extrapolando o domínio do enunciado tal como concebido por Ducrot (1987), para chegar ao domínio do enunciado concreto, ligado ao gênero (BAKHTIN, 1992, 2003). Em outras palavras, é olhar para as redações como gênero, constituído de elementos internos, seu enunciado, e de elementos externos, sua enunciação, ambos condicionados ao contexto sócio-histórico de produção, o exame vestibular. Por isso, tomo Ducrot (1987) como ferramenta de análise.

\section{B. A historicidade do gênero}

A análise do gênero redação de vestibular tem um caráter imediato, caracterizado pelo olhar voltado para a superfície textual; e um caráter menos imediato, aquele por meio do qual se analisa o gênero como uma prática social e discursiva, ou seja, considerando seu caráter histórico de constituição.

Contando com essa historicidade do gênero, a Análise do Discurso (cf. BRANDÃO, 1997; MAINGUENEAU, 2008 e outros) permite observar a produção textual da redação de vestibular a partir dos os movimentos enunciativos e discursivos nela presentes. 
A escrita, enquanto processo, remete à ação, movimento e compreende negociações discursivas, num processo de interação. O processo de escrita no vestibular implica jogo tenso de interação, em que o escrevente negocia o tempo todo com seu interlocutor. Circunscrever o gênero redação de vestibular no contexto teórico da Análise do Discurso significa, dentre outras coisas, estudar os papéis discursivos de seus interlocutores. É discutir as estratégias discursivas utilizadas pelos escreventes para construir PDVs, mobilizando seus saberes, transformandoos linguisticamente num enunciado, organizando-os em um gênero. Ou seja, o seu saber é materializado linguisticamente por meio de sequências textuais próprias do gênero que está em construção.

Os movimentos discursivos são constituídos pelo caráter argumentativo inerente ao próprio gênero estudado. Considero, assim, que o gênero redação de vestibular comporta uma dimensão argumentativa que pode ser tratada pela Análise do Discurso, o que permitiria ver a argumentação não só como uma das funções da língua, mas também sob a manifestação da exterioridade que penetra no discurso, favorecendo a busca do(s) sentido(s) do enunciado a partir da orientação argumentativa construída pelo escrevente em sua resposta a um interlocutor e a outros enunciados. Da perspectiva textual e discursiva, a argumentação também se realiza segundo estratégias argumentativas direcionadas para a construção de PDVs e do PDVD, ou seja, é possível localizar e descrever as posições enunciativodiscursivas do escrevente.

Desse modo, buscar as estratégias argumentativas para localizar e descrever a construção de PDVs exige um olhar para o todo do enunciado, isto é, olhar para cada uma das dimensões do gênero não de forma pontual e isolada, mas na relação de articulação entre elas. Assim, a análise não busca, por exemplo, operadores textuais ou dêiticos de pessoa, tempo e lugar isoladamente, mas considera a importância deles para a constituição das estratégias argumentativas a partir dos movimentos enunciativos e discursivos constatados por meio da análise de elementos qualificadores, caracterizados pela adjetivação e modalização dessa adjetivação, vistos como recursos delimitadores da construção de PDVs. A ideia é caracterizar esses elementos qualificadores em seus aspectos enunciativos e discursivos com a finalidade de encontrar modos de construção de PDVs, para elucidação do funcionamento discursivo do gênero estudado. 
Penso, assim, encontrar marcas de polifonia que delineiam esses modos de construção de PDVs. São estas pistas que guiarão minha análise. Para tanto, proponho, a seguir, a distinção feita por Nowakowska (2005, p. 20), que entende dialogismo e polifonia como conceitos vizinhos, mas distintos, e em relação de complementaridade.

\section{Polifonia e dialogismo}

Nos escritos de Bakhtin ou de seu círculo, a polifonia se situa no campo literário e o dialogismo é uma prática que governa toda prática linguageira, isto é, toda prática humana. Entretanto, os dois conceitos repousam fortemente sobre a ideia de diálogo, de interação entre discursos ou várias vozes (NOWAKOWSKA, 2005, p. 26).

A polifonia, inicialmente aplicada somente na esfera literária, é abordada por Bakhtin em Problemas da poética de Dostoievsk. Para o autor, Dostoievsk é o criador do romance polifônico. Posteriormente, a polifonia é trabalhada em outras esferas e por diversos autores. Ducrot (1987), como vimos, desenvolveu sua teoria polifônica, partindo dos postulados de Bakhtin, para contestar a unicidade do sujeito.

A polifonia é, pois, concebida como a presença de vozes - enunciadores que se manifestam no texto ao explorar as fronteiras entre o um e o outro. Nesses termos, "polifonia se define pela convivência e pela interação, em um mesmo espaço [...]" (BEZERRA, 2007, p. 194), do um e do outro. O mesmo diz Amossy (2005b, p. 65), "não se trata então da questão da fala do outro que necessariamente atravessa o sujeito e através do qual só ele pode se constituir, mas de 'pontos de vista' e de 'vozes' que veiculam um mesmo texto - e, em linguística, um mesmo enunciado". É, realmente, na interação e na convivência que PDVs são colocados em cena pelo escrevente.

Ainda segundo Amossy (2005b, p. 72), na polifonia, o locutor toma em carga os PDVs e os hierarquiza, marcando sua própria posição. A polifonia "permite ao discurso argumentativo implantar suas estratégias encenando um debate, ou um conjunto de PDVs, no seio de um discurso único" (AMOSSY, 2005b, p. 72). Ela consente uma construção argumentativa ampla, por meio de marcadores inscritos no enunciado; marcadores que revelam o outro no discurso. Ela está, assim, 
diretamente relacionada à presença desse outro, mas também de outros no discurso. Nesse sentido, a heterogeneidade é dada a partir das

formas marcadas que atribuem ao outro um lugar linguisticamente descritível, claramente delimitado no discurso, passando pelo continuum das formas recuperáveis da presença desse outro no discurso, chegando-se, inevitavelmente, à presença do Outro - às palavras dos outros, às outras palavras - em toda parte sempre presentes no discurso (AUTHIER-REVUZ, 2004, p. 21).

Essa intersubjetividade desvela a heterogeneidade mostrada da linguagem e permite revelar as imagens construídas tanto do escrevente (a imagem que ele constrói de si) quanto as que ele projeta de seu interlocutor.

No que se refere ao dialogismo, para Bakhtin (1986), não há enunciado fora da dimensão dialógica da linguagem. O dialogismo configura-se na relação entre o eu e o outro. O sujeito é construído nessa fronteira. Essa construção se dá num espaço social, num determinado tempo e sob condições específicas que são bem determinadas na situação de enunciação da redação de vestibular, que se realiza no curso mesmo da comunicação verbal. O autor salienta que, por esse fato, a situação de enunciação determina as dimensões e as formas da enunciação (1986, p. 125). O próprio gênero também se configura sob essas condições, como também configura a enunciação. Por conta disso, o valor ideológico das enunciações evidencia o aspecto histórico e social que está presente na linguagem e se manifesta linguisticamente nos enunciados das redações.

Na formulação de Amossy (2005b, p. 65), o dialogismo vai além da polifonia, portanto, de "voz de vozes que orquestram o locutor fazendo ressonar no seu discurso aquela do outro, ou dos outros". O sujeito é sempre, segundo a autora, dependente do discurso do outro. Nesse sentido, o dialogismo se organiza pela distinção entre dialogismo interdiscursivo (a relação com discursos anteriores) e interlocutivo (a relação entre os interlocutores), ambos moldados pela responsividade inerente ao enunciado.

A construção de PDVs, nessa perspectiva, toma o dialogismo como ponto de partida para a análise dos enunciados das redações, o que impõe, no plano enunciativo-discursivo, considerar as relações dialógicas em mais de um eixo, isto é, o interlocutivo, em que é fundamental o papel social dos interlocutores que se materializa no enunciado por meio da polifonia; e o interdiscursivo, que, 
fundamentando-se no já-dito, determina que a assunção do discurso se dê no ponto - necessário - de sua articulação com outros discursos.

Esses aspectos corroboram a afirmação de Bakhtin (1986) de que o dialogismo é constitutivo da linguagem e do sentido do enunciado. A linguagem é, pois, um fenômeno social e, como tal, compreende a construção do sujeito como ser histórico carregado de ideologias. Linguagem e sujeito estão entrelaçados. Ao se constituir como sujeito, o escrevente toma para si uma voz dominante, que se destaca em relação às demais presentes no enunciado. Essa voz dominante é assumida pelo escrevente na interrelação com seu interlocutor e deixa, no texto, traços da situação de enunciação, do gênero e do discurso.

Não são vozes (PDVs) apenas de quem fala, literalmente, mas vozes sociais. As "posições enunciativas" são, então, posições sociais: ao enunciar, assume-se "uma posição social ativa com respeito a certos valores específicos e esta posição é condicionada pelas próprias bases da existência social" (VOLOCHINOV [BAKHTIN], s/d: [1926], p. 9).

A enunciação constitui-se, pois, nas situações concretas de usos da língua e na relação social com suas respectivas hierarquias, condicionando as escolhas do escrevente. Por isso, a escolha dos certos recursos lexicais (como é o caso das adjetivações e dos modalizadores) vai depender da esfera na qual o enunciado está inserido (BAKHTIN, 1992). Os elementos que sustentam essas escolhas também evidenciam o caráter dialógico da linguagem, pois o escrevente faz suas escolhas não individualmente, mas em função do outro e na interação. Analisar a escrita em seus aspectos dialógicos é, pois, pensar no modo de incorporação desses elementos no gênero estudado.

Diante do exposto, há que se considerar o gênero redação de vestibular constituído como prática discursiva e em consonância com a heterogeneidade que o constitui. Pensá-lo como prática discursiva pressupõe estudar as particularidades de seus diálogos-respostas, suas réplicas, considerando o diálogo com os fragmentos da coletânea, com os autores desses fragmentos, bem como com outros discursos, numa relação de interdiscursividade. 


\section{Discurso e interdiscurso}

O gênero redação de vestibular é uma prática discursiva e, por isso, carrega em si crenças, valores sociais e culturais do grupo ao qual pertence seu escrevente. Em outras palavras, o discurso é o lugar da manifestação de posicionamentos do sujeito. No espaço do discurso, manifesta-se a multiplicidade de vozes que encenam diferentes "posturas enunciativas" (MAINGUENEAU, 2004,) abertas à constituição do escrevente. Esses lugares discursivos são passíveis de observações de elementos concernentes ao escrevente, bem como da permeabilidade dos discursos e saberes que os contornam. Essa permeabilidade dos discursos está inscrita nos enunciados de diferentes maneiras, algumas mostradas e marcadas, outras mostradas e não-marcadas (AUTHIER-REVUZ, 1990). O discurso caracteriza-se, assim, pelo princípio dialógico da linguagem (BAKHTIN, 1986, 1992) e, nesse sentido, ele é duplamente dialógico porque se inscreve e se circunscreve em outros discursos.

Para entender o que é o discurso e seu funcionamento é preciso lembrar que entendo o gênero como prática discursiva e, nesse sentido, ele é, ao mesmo tempo, produto, no qual se analisa sua materialidade linguística, e processo, cuja análise se volta para os aspectos de seu contexto de produção, para o exterior que o constitui. Para Brandão, é a heterogeneidade

que liga de maneira constitutiva o Mesmo do discurso com o seu Outro ou, em outros termos, que permite a inscrição no discurso daquilo que se costuma chamar seu "exterior" (BRANDÃO, 1997, p. 71).

Essa característica do discurso é pertinente para a análise das redações, uma vez que os enunciados nelas registrados são sempre respostas a outros enunciados, outros discursos. No que se refere à redação de vestibular, são respostas aos textos da coletânea fornecida na prova de redação e, também, a outros enunciados, outros discursos. Essa exterioridade que constitui o discurso o torna complexo, na medida em que se deve analisá-lo considerando sua historicidade. Os sentidos de um discurso são construídos nessa historicidade e, a partir dela, ele se materializa, marcando as formações discursivas das quais o sujeito enuncia. Formação discursiva entendida não como um espaço fechado, apenas determinando "o que pode e deve ser dito" (PÊCHEUX, 1997, p. 160) e 
controlando o sentido desse dizer, mas como um espaço aberto em que circulam outras formações discursivas, um espaço sem fronteiras, sujeito à dispersão. A formação discursiva está aberta para a circulação de discursos e, por isso, ela é "efeito da interdiscursividade" e se apresenta "como um domínio aberto e inconsciente e não como um domínio estável” (BRANDÃO, 1997, p. 74). O sujeito enuncia em relação a outros discursos e assume posições em relação a outras posições; posições que são histórica e socialmente constituídas, por isso, o sujeito enuncia a partir de lugares sociais, confluindo língua, sujeito e história. Há, nesse sentido, uma busca pela heterogeneidade enunciativa que Pêcheux (1990c, p. 316) tratou por "formas linguístico discursivas do discurso-outro", isto é, "o discurso do outro, colocado em cena pelo sujeito, ou discurso do sujeito se colocando em cena como um outro".

É nesse sentido que as posições assumidas pelo sujeito são também determinadas pelas condições de produção do discurso concebidas, neste trabalho, não apenas como a situação imediata de enunciação, mas também os elementos que ligam a história e a língua, isto é, as representações do sujeito (PÊCHEUX, 1990b, p. 171). Em outras palavras, são "o contexto sócio-histórico, os interlocutores, o lugar de onde falam, a imagem que fazem de si e do outro e do referente" (BRANDÃO, 1997, p. 89).

O discurso, segundo Maingueneau (2008b, p.15), é "uma dispersão de textos, cujo modo de inscrição histórica permite definir como um espaço de regularidades enunciativas". Essas regularidades dão as condições de "enunciabilidade" do discurso. Ele é, assim, determinado historicamente pela enunciação e condicionado em sua estrutura, o enunciado. Nesse sentido, "é preciso pensar ao mesmo tempo a discursividade como dito e como dizer, enunciado e enunciação (op. cit., p. 19). A partir dessas considerações, a análise dos enunciados das redações torna-se mais instigante, na medida em que ela toma como ponto de partida a definição de gênero proposta por Bakhtin, ou seja, analisar o gênero redação de vestibular no que se refere ao seu conteúdo temático, sua estrutura composicional e estilo. Se a enunciação determina o discurso, esses elementos não podem ser constituídos rigidamente, de forma fixa, mas condicionados por ela. $\mathrm{O}$ que permite retomar mais uma vez a definição de gênero em Bakhtin, no que se refere aos aspectos de suas regularidades. 
O discurso, devido às condições de sua "enunciabilidade", deve ser pensado como prática discursiva e, por isso, se encontra inscrito numa "rede institucional" (MAINGUENEAU, 2008b, pp. 22-3). A redação de vestibular está tomada pela carga institucional na qual está circunscrita, isto é, uma avaliação, o exame vestibular. Se a enunciação determina o que dizer e o como dizer, essa carga institucional está presente, está marcada nos enunciados das redações. E se está marcada, é porque o escrevente responde às coerções da enunciação, no processo interacional. É nesse ambiente que o linguístico e o social se articulam, evidenciando os aspectos enunciativos e discursivos presentes no gênero analisado, visto como prática discursiva.

Conceber o gênero como prática discursiva exige tratar do dialogismo que the é inerente. O diálogo proporcionado pela interação, conforme dito anteriormente, é visto de forma ampla, ou seja, não só entre seus interlocutores imediatos, escrevente e leitor, mas também entre os discursos que circulam no "espaço de trocas entre vários discursos convenientemente escolhidos" (MAINGUENEAU, 2008b, p. 20), esse espaço de trocas é chamado por Maingueneau de interdiscurso, noção importante para o percurso analítico que adoto na pesquisa. Trata-se, grosso modo, da relação entre discursos. O autor afirma que o primado do interdiscurso sobre o discurso remete para a interdependência desses discursos. Essa abordagem do interdiscurso não deixa de fazer eco com o que Bakhtin chama de dialogismo, quando o autor afirma que uma posição só é tomada na correlação com outras posições (BAKHTIN, 2003, p. 297). Desse modo, as escolhas do escrevente não são neutras. Então, quando o escrevente introduz o outro em seu discurso, por meio da inserção de enunciadores, de posturas enunciativas, ele está condicionado pela enunciação e, uma vez que a imposição parte dela, ditando o que dizer e o como dizer, não há como ocultar a heterogeneidade inerente da escrita. As vozes estampam os enunciados em suas multiplicidades, mostradas ou constitutivas (AUTHIEZ-REVUZ, 1990).

Diante dessas considerações, faz-se necessário tratar essa multiplicidade de vozes que encenam os enunciados, de modo geral, e, de modo particular, os enunciados das redações. 


\section{E. Memória discursiva}

O escrevente está submetido às coerções enunciativas, ou seja, às condições de produção do gênero redação de vestibular, sendo essas condições (cf. PÊCHEUX, 1990) referências não só do contexto de produção, "mas ainda as representações imaginárias que os interactantes fazem de sua própria identidade, assim como do referente de seus discursos" (MAINGUENEAU, 1998, p. 30). As redações de vestibular não podem ser analisadas solitariamente, isolada das condições sócio-históricas de produção. Considerando essas condições, tem-se: um tempo determinado, um número de linhas estabelecido, um gênero de antemão determinado, um tema conhecido (no momento da leitura da proposta de redação), critérios de avaliação, a não possibilidade de recorrer a arquivos para a produção do texto naquele momento, um leitor presumido. Essa amplitude das condições de produção envolve igualmente aquilo que "já foi dito e do que já foi ouvido" (MAINGUENEAU, 1998, p. 30), como também o que é determinado pela estrutura da ideologia (op. cit., p. 31). Tem-se, assim, um sujeito que se funda no interdiscurso, condicionado por sua memória discursiva, entendida como o re-dito, como já-enunciado, atualizado no momento do acontecimento discursivo. Segundo Pêcheux (1999, p.53), "haverá sempre um jogo de força na memória, sob o choque do acontecimento". Assim, a memória, neste trabalho, é entendida, como em Pêcheux (op. cit. p. 50), "não no sentido diretamente psicologista da 'memória individual', mas nos sentidos entrecruzados da memória mítica, da memória social inscrita em práticas [...]". Tendo o exame vestibular e, especificamente, o exame de redação como prática social, a memória discursiva do escrevente é atualizada nesse espaço social, em que diferentes coerções estão em jogo. Nesse sentido, o que é retomado, re-dito pelo escrevente, é determinado por essas coerções, bem como por suas representações.

Tomar a redação de vestibular como prática discursiva pressupõe considerar a forte influência do acontecimento discursivo na prática de escrita do vestibulando. A atualização do evento exame vestibular/exame de redação traz para os enunciados das redações os já-ditos sob dois aspectos: 1) aqueles tomados pela leitura imediata: os fragmentos da coletânea e a instrução da prova de redação, o que não se exclui igualmente a possibilidade de tomada de enunciados da prova de Língua Portuguesa como um todo e, 2) aqueles tomados de fontes diversas, mas 
moldadas também pelo evento. Considerar a influência do acontecimento discursivo na prática do escrevente inclui, ainda, todo o conhecimento prévio desse escrevente, tanto no que se relaciona com o evento em si, como o de fontes diversas das do evento. Esse conhecimento, visto como saberes, é tomado em função das representações que são construídas nessa atualização no acontecimento discursivo, isto é, de conhecimentos que o escrevente julga validados por seu outro, a instituição universidade.

Esses saberes trazidos pelo escrevente, como respostas a seus letramentos, são também construídos socialmente e são igualmente regulados numa situação bastante coercitiva de enunciação: um exame, com tempo determinado, tema e gênero impostos, etc. Nesse contexto de elaboração da redação de vestibular como gênero discursivo, o que seria, então, esse interior e exterior?

Analisar a redação de vestibular como gênero discursivo envolve considerar os efeitos polifônicos em que a interdiscursividade é inerente à linguagem. A escrita é construída nesse espaço em que o sujeito pensa estar no controle de suas ações, mas ele é traído por sua própria historicidade, pela formação discursiva da qual faz parte, pela ideologia que o circunda. Nesse espaço discursivo, sentidos são construídos a partir dos letramentos do escrevente, de sua leitura e da retomada da coletânea, de seus conhecimentos prévios, das retomadas de discursos constituídos em função do exame vestibular - critérios de correção da prova de redação -, do interlocutor presumido, etc. A única fonte de que dispõe para consulta imediata são os fragmentos da coletânea e os enunciados da prova de português como um todo. Essas retomadas, alteradas no momento da atualização discursiva, têm seus efeitos de sentidos igualmente alterados. Isso porque,

[...] na medida em que retiramos de um discurso fragmentos que inserimos em outro discurso, fazemos com essa transposição mudar suas condições de produção. Mudadas as condições de produção, a significação desses fragmentos ganha nova configuração semântica. (BRANDÃO, 1997, p. 77).

Tem-se de imediato, condições de produção determinadas pelo evento, conforme dito anteriormente e, ao mesmo tempo, tem-se essas ressignificações, ambas fazendo-se marcar no enunciado das redações ao construir PDVs. Ou seja, os PDVs são construídos, sob essas condições, na relação com os já-ditos, 
atualizados no acontecimento discursivo. Assim, a memória discursiva é vista neste trabalho, como aquela que

separa e elege dentre os elementos constituídos numa determinada contingência histórica, aquilo que, numa outra conjuntura dada, pode emergir e ser atualizado, rejeitando o que não deve ser trazido à tona. Exercendo, dessa forma, uma função ambígua na medida em que recupera o passado e, ao mesmo tempo, o elimina com os apagamentos que opera, a memória irrompe na atualidade do acontecimento, produzindo determinados efeitos (BRANDÃO, 1997, p. 77).

Esses efeitos estão diretamente relacionados com a construção de PDVs, que é toda moldada pelas condições de produção e pela atuação da memória discursiva. Os PDVs - as posições do escrevente - são constituídos, regrados por essa memória, ou seja, por uma memória do já-dito, por uma memória do dizer esse jádito e, além disso, são determinados ideologicamente no processo de escrita. Assim, a construção de PDVs é dada nesse espaço, em que o linguístico e o extralinguístico se fundem, ou seja, na própria constituição do discurso.

O escrevente constitui-se como sujeito no discurso, porque se trata de um espaço dialógico, em que o eu se instaura com o seu Outro. É nesse sentido que o sujeito se constitui histórica e, portanto, ideologicamente. Em razão disso, seu discurso caracteriza-se pela heterogeneidade, pois assume diferentes vozes, constrói diferentes posições enunciativas e PDVs, resultando essa construção de PDVs em efeitos polifônicos, cujos sentidos se dão na própria interação entre o eu e o Outro. Por isso, o sentido não está pronto no texto, esperando para ser detectado. Ao contrário, ele é construído na opacidade da interação entre escrevente-leitor.

Deve-se levar em conta, também, que o escrevente é interpelado pela ideologia e que, por isso, ele não é sujeito de si, mas constituído conforme a formação discursiva que o domina. Em sua constituição como sujeito o escrevente ocupa posições enunciativas que convergem para um PDVD; este, fundado no interior da formação discursiva da qual pertence o escrevente. Vale salientar que a dominância se constitui na relação com outras formações discursivas que estão entrelaçadas nos enunciados. Nessa direção, a construção do PDVD tem a ver tanto com a constituição do escrevente como sujeito historicamente constituído, como com a heterogeneidade inerente à linguagem e que se manifesta nos enunciados de diferentes maneiras, seja mais mostrada ou mais opaca. 
Assim, estudar a qualificação por meio da adjetivação e da modalização, bases linguísticas da análise das redações, constitui um lugar privilegiado para observar como se estabelece o processo discursivo da construção de PDVs na redação de vestibular e como o PDVD se constrói. Nesse processo é importante saber como o escrevente se constitui como sujeito no gênero redação de vestibular.

\section{F. Sujeito}

Neste trabalho, adoto a noção de sujeito como aquele que se constitui na historicidade das práticas sociais e no interdiscurso, isto é, um sujeito que não é a fonte do sentido e que não controla o seu dizer. O sujeito é filiado sóciohistoricamente e, por isso, é atravessado por determinações mais ou menos conscientes (PÊCHEUX, 1990). Nesse sentido, o sujeito age consciente e, ao mesmo tempo, inconscientemente. Ele não controla o seu dizer, mas interage com outros dizeres, mesmo sem perceber isso. Esse atravessamento está relacionado com o lugar social de onde o sujeito enuncia, a partir de determinadas formações discursivas "que representam 'na linguagem' as formações ideológicas que Ihes são correspondentes" (PÊCHEUX, 1997, p. 161). É um sujeito social e historicamente constituído, trata-se, portanto, de um sujeito ideológico e se contrapõe a um sujeito individual.

Como dito anteriormente, o escrevente constitui-se como sujeito no espaço discursivo da interação, porque se trata de um espaço dialógico, em que o eu se instaura com o seu Outro. É nesse espaço que os sentidos são construídos: espaço que reúne o um é o outro, complementando-se na historicidade e na construção da memória:

o sentido de uma palavra, de uma expressão, de uma proposição, etc., não existe 'em si mesmo' [...], mas, ao contrário, é determinado pelas posições ideológicas que estão em jogo no processo sóciohistórico no qual as palavras, expressões e proposições são produzidas (isto é, reproduzidas) (PÊCHEUX, 1997, p. 160).

Segundo Brandão (1997, p. 62), o sujeito se constitui numa relação dinâmica entre o um e o Outro, ou seja, entre a identidade e a alteridade. Ambas constituem o espaço discursivo no qual o sujeito se constrói. Se o sujeito se constitui nesse espaço, é necessário compreender como esse processo de construção do sujeito acontece, quando se trata do sujeito que escreve o gênero redação de vestibular - o 
escrevente, para mim -, por se tratar de uma interação numa situação de enunciação singular como a do exame vestibular, ou seja, uma avaliação escolar.

O exame vestibular é considerado um evento escolarizado e, nesse sentido, trata-se de uma situação na qual o escrevente já se encontra familiarizado. Entretanto, é uma situação de avaliação diferente daquela que se passa na escola, no dia a dia da sala de aula. Isso porque, o escrevente é avaliado por um interlocutor que é desconhecido seu. Apesar desse distanciamento, o escrevente constrói para si a imagem do que esse avaliador representa para ele. Imagem que constitui um configurado na relação entre escrevente - que necessita cumprir os critérios de correção da prova de redação para aumentar a possibilidade de ser aprovado no exame vestibular e acessar a universidade - e avaliador, que também tem por parâmetro, para a correção, os critérios adotados para tal.

Desse modo, o espaço interativo em que o sujeito - o escrevente - se constitui, é um espaço bastante singular. De um lado, o escrevente tem conhecimento de que será examinado com critérios previamente estabelecidos. Embora esses critérios estejam disponíveis no manual do candidato, não há garantia de que o escrevente os tenha lido. Apesar dessa possibilidade, o escrevente sabe o que deve cumprir nessa prova: escrever um gênero previamente determinado, em que deve provar que sabe produzi-lo adequadamente aos critérios de correção estabelecidos. Essas coerções constituem-se, assim, em relações interdiscursivas no sentido de que tanto o eu quanto o Outro vão se construindo por meio dos jáditos. A constituição do eu e do Outro está presente nos enunciados, seja de maneira mais marcada ou mais apagada, mas está ali, evidenciando a heterogeneidade da escrita. Esse modo de presença apresenta, em sua materialidade linguística, traços do evento, do acontecimento discursivo. Assim, o gênero redação de vestibular é formalizado linguisticamente por suas determinações genéricas e moldadas pelo acontecimento discursivo, em que o eu e o Outro se estabelecem simultaneamente. Vejo esse estabelecimento do um e do Outro como tomadas de posições - posições enunciativas - em que PDVs são construídos.

A construção de PDVs e, principalmente do PDVD, é determinada também pelas coerções ligadas ao evento vestibular, de ordem sócio-históricas, isto é, as pressões exercidas pela sociedade (escola, família, Estado) que quer a pessoa na universidade. Os papéis sociais estabelecidos pelo evento, o exame vestibular, a 
saber, o vestibulando-escrevente e o corretor-leitor são materializados no texto e podem ser caracterizados em suas relações com o gênero. Além disso, considerando que um gênero é também constituído estilisticamente, a presença do eu no Mesmo, será também visualizada em sua materialidade linguística. É nessa singularidade, justamente onde se poderia ver o maior apagamento do sujeito, em que acredito encontrar o sujeito no gênero redação de vestibular. Essa singularidade é, de certa maneira, correlacionada e responsiva ao perfil do leitor presumido, a banca corretora.

Em síntese, tomar o estudo da redação de vestibular na perspectiva enunciativo-discursiva é articular aspectos textuais, enunciativos e discursivos vistos como respostas ao caráter sócio-histórico do gênero. Resta, ainda, além da apresentação desses aspectos, relacioná-los aos estudos da construção de PDVs, objeto de análise da pesquisa. 


\section{CAPÍTULO 2}

\section{INCURSÕES TEÓRICO-METODOLÓGICAS SOBRE "PONTO DE VISTA"}

\subsection{A construção de PDVs}

Adotada para a pesquisa a teoria da enunciação de Bakhtin (1986, 1992; 2003), que trata dos aspectos do dialogismo e da relação do sujeito com o enunciado, destacando fatores históricos e sociais inerentes à linguagem, assumo, portanto, a perspectiva que concebe a linguagem como interação, seja de posicionamentos, seja de discursos.

A obra de Bakhtin é um convite à reflexão sobre a natureza e a função da linguagem na instância enunciativa em que os aspectos sociais são fundamentalmente importantes. Nessa perspectiva, interação é palavra-chave. No caso da escrita, interação entre escrevente, texto e contexto sócio-histórico. A esse processo, Bakhtin chama dialogismo que, para o autor, é uma propriedade constitutiva da linguagem e a condição dos sentidos. A concepção de diálogo em Bakhtin é, pois, constitutiva da linguagem tomada como fenômeno heterogêneo. Por sua vez, as práticas de linguagem são marcadas pelas representações dos escreventes, refletindo tanto a diversidade das esferas de atividades humanas como as condições sociais de sua existência. Sintetizando, assumo que interagir pela linguagem é disseminar sentidos e significa realizar uma atividade discursiva sob determinadas condições de produção.

Para explicitar o que entendo por PDVs, discuto noções que tratam dos fenômenos da linguagem em sua complexidade: polifonia, heterogeneidade, dialogismo, enfim, PDV.

\subsection{Sobre a noção de ponto de vista}

A noção de PDV tem sido mais explorada nos estudos de textos da esfera literária. Esboço breve percurso histórico desses estudos, com o objetivo de buscar 
a fonte da noção ponto de vista e, principalmente, sustentar minha opção por Rabatel, cujos estudos do PDV têm seus pilares na teoria da enunciação.

Em sua obra, Une histoire du point de vue, de 1997, resultado de sua tese de doutoramento, Rabatel faz uma análise crítica e histórica das principais abordagens desse tema, abrangendo autores como Pouillon, Genette, Todorov, Bal, Ricoeur, Eco, dentre outros. Esses autores tratam do tema em estudos da esfera literária, como Rabatel, no início de suas pesquisas. Entretanto, em artigos mais recentes, o autor também estuda o fenômeno em textos de diferentes esferas e gêneros discursivos. Não me detenho em cada um desses autores estudados por Rabatel; limito-me à síntese de suas ideias e à crítica a eles, feitas por Rabatel. Apresento, posteriormente, a definição de ponto de vista do autor e sua abordagem da construção textual do PDV, baseada em sua extensa obra, com destaque para a obra La construction textuelle du point de vue, escrita em 1998, mas utilizando, também, artigos mais recentes, em que reformula alguns aspectos de sua teoria. Interessam-me, particularmente, seus estudos relacionados à articulação da noção de PDV à construção da argumentação, como mostrarei adiante.

Pouillon ${ }^{21}$ trata o fenômeno do PDV, segundo Rabatel (1997), sob três visões: visão com, visão por detrás, visão de fora ${ }^{22}$. Nessa mesma direção e, inspirado em Pouillon, Genette ${ }^{23}$ tratou o mesmo fenômeno sob o viés da focalização: focalização zero, focalização interna e focalização externa. Bal $^{24}$ adota uma teoria binomial e usa as expressões focalização para e focalização sobre ${ }^{25}$. Já Ricoeur ${ }^{26}$ se inscreve na tradição hermenêutica alemã, diferenciando-se fortemente desses outros autores ao abordar o PDV na perspectiva do tempo.

Para Genette, na focalização interna, os fatos são descritos no plano da subjetividade, ou seja, uma perspectiva que olha de dentro, que participa; o

${ }^{21}$ Rabatel se baseia no texto: POUILLON, J. Temps et romans. Paris: Gallimard, 1946, réédition 1993.

${ }^{22}$ La vision avec (PDV dos personagens), La vision par derrière (PDV do narrador), e La vision du dehors (visão ligada às duas primeiras visões).

${ }^{23}$ Rabatel se baseia nos textos: GENETTE, G. Figures II, Paris: Seuil, 1969; Paris: Seuil, 1972; diction, Paris: Seuil, 1991. Nouveau discours sur Le récit, Paris: Seuil, 1983; Figures III,

${ }_{24}$ Ranal Poétique, 29, Paris: Seuil, 1977a;

${ }^{25}$ Focalisation par e focalisation sur.

${ }^{26}$ Rabatel se baseia no texto RICOEUR, P. Temps et récit, tome I, Paris: Seuil, 1983;

Temps et récit, tome II, Paris: Seuil, 1984; Temps et récit, tome III, Paris: Seuil, 1985. 
personagem é também narrador. Já na focalização externa, o narrador não é um personagem, é um observador distante, portanto, os fatos são narrados no plano da objetividade. A focalização zero é a ausência de focalização, uma vez que os fatos são narrados por conta própria. Para Rabatel, as três visões de Pouillon foram rebatizadas por Genette, que apresenta o mesmo fenômeno, mas em uma nova tipologia textual.

Pouillon aplicou, no romance, sua teoria sobre "as visões". O autor compreende que existe uma relação particular entre o autor de uma obra e seus personagens (RABATEL,1997, p. 26) ${ }^{27}$, mas ele não faz distinção entre narrador e autor. Na visão com, o personagem é considerado o centro da obra, ou seja, o leitor vê os outros personagens e o desenvolvimento dos acontecimentos a partir da visão do personagem principal, mas o leitor não acessa o pensamento dos demais personagens (Ibid., p. 27) ${ }^{28}$. Na visão detrás, o centro de perspectiva é o romancista (autor ou narrador para Pouillon), sem coincidir com seus personagens. É quem conhece tudo, é onisciente. O autor pode fazer porta-voz um de seus personagens para transmitir suas ideias (lbid., p.28) ${ }^{29}$. Já a visão de fora, que não é contrária à visão de dentro, é uma visão vista pelo lado de fora, materialmente observável, revelando principalmente aspectos físicos dos personagens que, por sua vez revelam o personagem por dentro (Ibid., p.29) ${ }^{30}$. Rabatel critica principalmente esta última visão que, segundo ele, não é independente das demais, não é uma visão no sentido estrito da palavra, porque está subordinada tanto à visão por detrás quanto à visão com (lbid., pp. 30-1) ${ }^{31}$.

A problemática da perspectiva é reintroduzida nos estudos de Genette, mas é tratada pelos modos de distanciamento daquele que narra e do que é narrado. Essa distância visa à quantidade de informações fornecidas, enquanto que a perspectiva

27 "Elles [des modes de la compréhension] se définissent, pour ce que regarde la compréhension romanesque, d'une part selon les relations de l'auteur envers ses personagens, d'autre part selon la nature de ce que cette compréhension atteint. [...] J. Poilloun n'établit pás de distinction, une fois encore, entre auteur et narrateur".

28 "elle [la vision avec] consiste à privilegier dans le roman un personnege, et à le consdiderer comme le centre de l'ouvre".

29 "'la vision par derrière" établit son centre de perspective 'dans le romancier en tant qu'il soutient son oeuvre sans coïncider avec un de ses personnages [...] J. Pouillon precise que cela n'empêche pas que l'auteur ne puisse se servir d'un des personnages comme le 'porte-parole de ses idées personelles".

30 '“c'est la conduit em tant qu'elle est matériellment observáble. C'est aussi l'aspect physique du perssonage"'.

31 "[...] la 'vision du dehors' n'est pas une vision indèpendante: elle ne peut littèralement pas avoir l'autonomie des deux types de vision précédentes [...]". 
fornece informações sem que elas passem necessariamente por meio de um personagem. Ou seja, Genette diferencia aquele que fala (que conta) daquele que vê (GENETTE, 1972, p. 183-4) ${ }^{32}$. O que lhe permite dizer que é o PDV que organiza a narrativa. Essa diferença é o ponto de partida de Genette, para sua teoria da focalização. Para ele, na focalização zero (visão por detrás, de Poiullon), o narrador sabe mais do que o personagem, ou seja, é onisciente; faz análise dos personagens, os conhece por dentro e por fora; sabe de coisas que vão acontecer com eles no futuro, antes mesmo de eles saberem (GENETTE, 1972, p. 203). Na focalização interna (visão com, de Poiullon), as informações são dadas pelos personagens; por um só, ou por mais de um, mas em momentos diferentes, para o autor, instâncias focalizantes diferentes (cf. o romance Madame Bovary, exemplifica Genette) (lbid., pp. 206-8). A terceira focalização, a externa (visão de fora, de Poiullon), refere-se a uma narrativa mais objetiva, em que se utiliza a terceira pessoa.

Para Rabatel, a teoria de Genette é fraca e reduz "a problemática do PDV à vista" (RABATEL, 1998, p. 8) ${ }^{33}$, isto é, somente ao conjunto de percepções em que o PDV é determinado pela identificação de quem vê e sabe (Ibid., p. 8-9). Outra crítica refere-se à focalização zero, que Genette classifica como não-focalização e que, para Rabatel, é "uma concepção pela falta" (RABATEL, 1997, p. 67) ${ }^{34}$. O que está em jogo nas críticas de Rabatel é a ausência de perspectivas de leitura no que se refere ao "sentido da obra ou da ideologia do texto" (Ibid., p. 85)

A narratologia geral é o quadro em que se inscrevem as ideias de Bal. A autora analisa a focalização em relação direta com as instâncias narrativas, sendo a própria focalização uma dessas instâncias. A autora, segundo Rabatel, critica a teoria genettiana de focalização por questões de ambiguidades em suas definições no que se refere ao sujeito da vista ou ao objeto da vista, ou seja, a instância que vê ou que é vista. Assim, o narrador vê mais do que o personagem, ou o narrador vê

\footnotetext{
32 "Le récit peut fournir au lecteur plus ou moins de détail, et de façon plus ou moins directe et sembler ainsi se tenir à plus ou moins 'grande distance' de e qu'il raconte [...] l' information donnés par le récit et choisie d'apres les capacités de connaissace de telle ou telle partie prenante (personnage ou groupe de personnages dont il adopter ou feindra d'adoter ce que l'on nomme la "vision" ou le "point de vue", semblant alors prende à l'égard de l'histoire telle ou telle distance.".

33 "cette notion [...] à réduire la problematique du PDV à la vue.".

34 "tout laisse penser que Genette oscille entre deux directions opposées, une conception par excès, et une conception par défaut [...].".

35 "sens de l'oeuvre ou d'idéologie du texte".
} 
com o personagem respectivamente e vice-versa. Segundo Bal, essa confusão ocorre em virtude do emprego do termo focalização, por Genette, "não ser suficientemente unívoco para considerar as possibilidades narrativas" (BAL, apud RABATEL, 1997, p. 90) ${ }^{36}$ que ela considera ao utilizar-se desse termo. Para ela, o termo "focalização" está mais apto para levar em conta o fenômeno enunciativo, que acumula por sua vez, olhar e visão. Ela usa o termo focalização no sentido de centro de interesse, isto é, "o resultado da seleção, entre todos os materiais possíveis, do conteúdo da narrativa" [...] o centro de interesse "comporta 'a vista', a visão, também no sentido abstrato de 'considerar algo sob certo ângulo' [...]. O sujeito e o objeto dessas três atividades são as instâncias na narrativa." (RABATEL, 1997, p. 91, grifos da autora) ${ }^{37}$.

Bal propõe dois tipos distintos de focalização: focalização para, que se refere ao sujeito da visão, é o focalizador, ou seja, o sujeito percebente e, focalização sobre, que se refere ao objeto da visão, é o focalizado, o objeto percebido. Rabatel (1997, p. 92ss) critica a posição de Bal, alegando problemas de definição que, quando ocorre, é frouxa ou o uso de certos termos é muito metafórico, como na definição dada pela autora para os termos sujeito e objeto. Além disso, segundo Rabatel, Bal exclui a focalização zero de sua teoria e considera, erroneamente, o focalizador como uma instância.

Ricouer trata a problemática do PDV pelo viés do tempo vivido, em que o sentido da narrativa resulta de uma configuração, fruto de um trabalho interpretativo do leitor, que "não é livre para escolher esse ponto de vista que decorre da perspectiva da qual é apresentado o texto." (RICOEUR, apud, RABATEL, 1997, p. $205)^{38}$. Rabatel parece admitir algumas ideias de Ricoeur, no que se refere à construção de sentido pelo leitor. O autor admite que na multiplicidade de PDVs está a coerência do texto. Entretanto, ele critica a multiplicidade de perspectivas narrativas concebidas por Ricoeur, principalmente a dominância do narrador como instância dirigente da leitura (lbid., p. 206).

\footnotetext{
36 "C'est pouquoi le terme de focalisation tel qu'il est employé par Genette n'est suffisamment pas univoque pour rendre compte des possibles narratifs".

37 "Ie résultat de la sélection, parmi tous les matériaux possibles, du contenu du récit. [...] il comporte 'la vue', la vision, aussi dans le sens abstrait de considérer quelque chose sous um certain angle [...] le suje et l'objet de ces trois activités sont les instances du récit".

38 "Le lecteur n'est pas libre de choisir ce point de vue qui découle de la perspective dans laquelle est présenté le texte.".
} 
Rabatel constrói sua teoria do PDV a partir da leitura crítica de vários outros autores. Selecionei apenas os quatro que julguei mais pertinentes e expus, sinteticamente, como o autor conduz sua crítica a eles. Como se verá na sequência, não são, porém, esses os aspectos que quero destacar na teoria de Rabatel. No próximo item, trato especificamente da teoria do PDV elaborada por Rabatel (1997, 1998), que propõe dois PDVs, bem como de algumas alterações e complementações que ele faz em seus artigos mais recentes (2001, 2004, dentre outros), em que abandona a bipartição dos PDVs e apresenta uma tripartição.

As críticas de Rabatel a seus antecessores referem-se às contradições que ele vê em suas formulações. Sua crítica mais intensa está relacionada à expressão linguística da origem das perspectivas narrativas que, segundo o autor, quando abordada, não é aprofundada. Para ele, faltam critérios linguísticos e semióticos que permitam distinguir claramente o processo de percepção do focalizador e as marcas da representação do focalizado (RABATEL, 1997, pp. 93-5). Em outras palavras, os autores criticados por Rabatel centralizam a discussão do PDV em quem vê ou quem fala. Rabatel, no que se refere à expressão linguística do PDV, vai mais longe e insiste na busca não só da fonte do PDV, mas de como essa percepção é formulada linguisticamente e quais implicações estão em jogo nela. São esses aspectos que me interessam no pensamento do autor.

A decisão de estudar a perspectiva de Rabatel deve-se ao fato de ele construir uma abordagem linguística fundada essencialmente sobre a subjetividade da linguagem posta pela teoria da enunciação. O termo ponto de vista é, segundo Rabatel (1998, p. 7), parassinônimo de focalização narrativa e está relacionado com a perspectiva adotada na escrita do texto. Nos estudos linguísticos, essa noção é deixada um pouco de lado e o PDV é direcionado para focalização de informações (novas) em um texto, além de se exigir a procedência, a fonte dessas informações: "os critérios linguísticos do PDV repousam essencialmente num conjunto de traços que concernem às relações entre um sujeito focalizador da origem de um processo de percepção e um objeto focalizado" (RABATEL, 1998, p. 9, grifos do autor) ${ }^{39}$.

\footnotetext{
39 "Les critères linguistiques du PDV reposent essentiellment dans un ensemble de traits que concernent les relations entre un sujet focalisateur à l'origine d'un procès de perception et un objet focalisé.".
} 
Estudar o(s) PDVs é, assim, estudar os fenômenos de suas expressões linguísticas, ou seja, a percepção do PDV e sua complexidade, uma vez que não tem como separar nitidamente as diferentes perspectivas e detectar suas fronteiras em um texto. Para a identificação das percepções, isto é, para que exista PDV, não basta que o escrevente perceba alguma coisa, a percepção "deve ser predicada e, em seguida, desenvolvida, aspectualizada em progressões temáticas variáveis" (op. cit.) ${ }^{40}$. Esses índices indicam a existência do PDV e, por conseguinte, "indicam de qual focalizador correfere a referenciação do focalizado" (op. cit.) ${ }^{41}$. A partir do estudo do desenvolvimento desses aspectos, o autor constrói sua teoria, que dá instrumentos para o analista observar aspectos textuais da construção do PDV.

Rabatel (1998) elabora sua teoria em estudos da esfera literária; inicialmente, defende a distinção entre dois tipos de PDVs: o do personagem e o do narrador. $O$ autor enfatiza o jogo que ocorre entre esses dois PDVs. Mas, em artigos mais recentes, que se distanciam teoricamente em alguns aspectos de seus primeiros trabalhos, o autor estuda o PDV sob o ângulo dos valores argumentativos. Como ficou dito, são os aspectos da construção argumentativa e da expressão linguística que me interessam destacar de seus trabalhos. Antes, porém, vale mostrar, brevemente, seu percurso desde os estudos da esfera literária até os estudos mais recentes, em que trata de gêneros de esferas diferentes da literária.

A abordagem do PDV em Rabatel "repousa sobre uma dialética entre o sujeito de consciência e da origem das percepções e da referenciação das percepções representadas" (RABATEL, 1998, p. 9) ${ }^{42}$. Essa abordagem o leva a abandonar a tripartição que defendem alguns dos autores por ele criticados. $O$ autor justifica a bipartição pela existência de apenas dois sujeitos como origem das perspectivas narrativas: o narrador e o personagem. O que há entre eles, segundo o autor, é um jogo que transparece da opacidade de suas fontes, daí a dificuldade em traçar nitidamente as fronteiras entre diferentes PDVs. Rabatel assume, então, a abordagem que propõe um jogo entre os PDVs. Há nesse jogo, intervenções e interpretações, não sendo possível falar em objetividade e imparcialidade, uma vez que a subjetividade é que evidencia a própria instância, a origem do PDV.

\footnotetext{
40 "il fault encore que cette perception, d'abord prédiquée, soit ensuite développée, aspectualisée dans des progressions thématiques variables.".

41 "indiquent à quel focalisation coréfère la référenciation du focalisé".

42 "Notre approche du PDV reposant sur une dialectique du sujet de conscience à l'origine des perceptions et de la référenciation des perceptions représentées".
} 
Para o autor, a conjunção dos PDVs está no seio da cenografia enunciativa porque o PDV é um fenômeno enunciativo e contribui para a construção da personagem e da própria interpretação com base nas instruções do texto, dando coerência e legibilidade ao texto. O PDV "participa da construção das interpretações e especificamente de interpretações legítimas, isto é, das interpretações construídas, legitimadas pelo texto ele mesmo" (RABATEL, 1998, p. 192) ${ }^{43}$. Essas interpretações têm referências dêiticas e são testemunhas de um centro de perspectivas, são construídas no texto, podendo ser nomeado ou não.

Rabatel dá uma primeira definição do PDV:

O PDV corresponde à expressão de uma percepção, em que o processo, assim como as qualificações e modalizações, correferem ao sujeito percebente e exprimem de certa maneira a subjetividade dessa percepção (RABATEL, 1998, p. 13) ${ }^{44}$.

O PDV, assim, não se refere especificamente aos modos do discurso reportado, mas igualmente aos discursos sem fala, expressos nos enunciados narrativos. Esse fato corrobora a pesquisa no que tange à análise de elementos qualificadores e modalizadores dos enunciados das redações. Estes, em uma análise mais superficial, poderiam ser considerados como não portadores de vozes. O processo de percepção é muito mais nítido nos enunciados com identificação clara dos ditos (por exemplo, discurso reportado), mas o PDV possui uma irredutibilidade que está no fato de que "ele não tem necessidade de falas de personagem para se exprimir" (RABATEL, 1998, p. 14) ${ }^{45}$. Além disso, a percepção é bivalente no sentido de que há tanto a percepção do que se vê ("o espetáculo sobre o qual a vista para") como uma opinião particular, isto é, há "duas facetas de um mesmo fenômeno" (BAL, apud RABATEL, 1998, p. 14) ${ }^{46}$. Isso porque a percepção, no nível da expressão linguística, não se limita ao que se vê, mas inclui, também, o que se depreende do objeto observado, é um movimento duplo.

\footnotetext{
43 "participe à la construction des interprétations et, spécifiquement, des interpétations legitimes, c'està-dire des interprétation construites, légitimées par le texte lui-même.

44 "Le PDV correspond à l'expression d'une perception, dont le procès, ainsi que les qualifications et modalisations, coréferent au sujet percevant et expriment d'une certaine manière la subjectivité de cette perception.".

45 "Il y a une irréductibilité du PDV, qui repose d'abord dans ce fait qu'il n'a pas besoin des paroles de personnage pour s'exprimer.".

46 "'spectacle sur lequel la vue s'arrete'”; "[...] les deux facettes d'un même phénomène d'appéhension".
} 
Em sua segunda definição do PDV, ainda sob a perspectiva da bipartição, o autor afirma que o PDV corresponde a certa subjetividade expressa nos enunciados de terceira pessoa, no tempo passado (RABATEL, 1998, p.18).

No que se refere à terceira definição, diz o autor:

O PDV corresponde à expressão de uma percepção que associa sempre mais ou menos processos perceptíveis e processos mentais, essa intrincação sendo uma das marcas específicas da subjetividade do PDV (lbid., p. 23) ${ }^{47}$.

Considerando que o PDV supõe não somente a existência de um sujeito percebente, mas também de um processo de percepção e, sobretudo, uma expressão particular dessa percepção, pode-se dizer que, nesse sentido, entram em cena fenômenos linguísticos que transformam uma simples percepção em uma percepção representada, que é justamente sua quarta definição de PDV:

Uma percepção representada é um processo pelo qual uma percepção não é somente predicada, mas ainda feita o objeto de uma expansão no curso da qual o focalizador detalha diferentes aspectos de sua percepção inicial, comentando algumas características. Podemos considerar que os mecanismos de aspectualização de um tema-título de uma descrição podem, sob certas condições, construir essa representação.

[essa representação não se limita] a uma predicação, sendo completada pelas qualificações e modalizações que o expandem (Ibid., p. 24) ${ }^{48}$.

As predicações auxiliam na captação do PDV, colocando em foco o "objeto de discurso", e pressupõem a existência de uma fonte enunciativa, um enunciador que se sobrepõe aos demais na cadeia hierárquica. A predicação pode introduzir um elemento novo.

O próprio autor, contestando as marcas de identificação dos PDVs, seja do narrador ou do personagem, que centraliza a discussão em quem vê ou quem diz,

\footnotetext{
47 "Le PDV correspond à l'expression d'une perception qui associe toujours plus ou moins procès perceptifs et procès mentaux; cette intrication étant une des marques spécifiques de la subjectivité du PDV.

${ }^{48}$ Une perception représentée est un processus par lequel une perception n'est pas seulement prédiquée, mais encore fait l'objet d'une expansion au cours de laquelle le focalisateur soit détaille différents aspects de sa perception initiale, soit en commente certaines caractéristiques. Nous pouvons considérer que les mécanismes d'apectualisation d'un thème-titre d'un description peuvent, sous certaines conditions, construire cette représentation.

[...] ne se limitant pas à une prédication et étant complétée par les qualifications et modalisations qui l'expansent.".
} 
apresenta, em estudos posteriores, uma tripartição dos PDVs, mas não abandona o jogo polifônico que existe entre eles. Na verdade, o que muda é o foco visto não mais entre o quem vê ou quem diz, mas na apresentação do referente por diferentes marcas linguísticas, não se restringindo apenas aquelas mais tradicionais.

Rabatel (2000) apresenta três tipos de PDVs: PDV representado, PDV narrado e PDV assertivo $^{49}$ e, apesar de estar relacionado à narrativa, o funcionamento deles é diferente. De acordo com o autor, essa tripartição "distanciase do sistema genettiano, e se aproxima da análise dos fenômenos da heterogeneidade enunciativa" (2000, p. 195 $)^{50}$, além disso, permite discutir o fenômeno no quadro da argumentação, primeiramente a argumentatividade da narrativa. Apresento sucintamente a definição desses PDVs. Isso, porque, em trabalho posterior (RABATEL, 2004), o autor apresenta outra tripartição mais relacionada a estudos de diferentes gêneros e esferas. Desse modo, amplia-se o leque do estudo do PDV articulado com a argumentação, aspecto de maior interesse desta pesquisa.

Cada um dos PDVs apresentados tem sua definição resumida, sendo destacados apenas aspectos pertinentes para a pesquisa.

\section{O PDV REPRESENTADO}

O PDV representado é um fenômeno enunciativo próximo do discurso indireto livre. Para esse PDV, é importante a distinção entre dois planos de narração. O primeiro plano narra os acontecimentos na forma sucessiva e progressiva do aspecto cronológico. Já no segundo, não há uma ordem cronológica e o imperfeito, tempo típico deste plano, é o lugar privilegiado desse PDV. É a partir do segundo plano que o enunciador desenvolve suas percepções, uma exigência deste PDV, segundo Rabatel.

\section{O PDV NARRADO}

\footnotetext{
${ }_{50}^{49}$ Le représenté, le raconté e l'asserté.

50 "éloignée du système genettien, et proche de l'analyse des phénomènes d'hétérogénéité énonciative".
} 
Há um segundo tipo, o narrado, construído pelo fenômeno da empatia, que, para o autor, está relacionado à "atitude do locutor do olhar dos protagonistas do acontecimento: esse fenômeno consiste mais precisamente em apresentar informações a partir de um dos atores do enunciado" (RABATEL, 2000, p. 209) ${ }^{51}$. A empatia possui diferentes graus; neles, o locutor pode lançar sua observação com algum distanciamento, ao sair, por algum momento, de seu lugar focalizante, isto é, "adota o ponto de vista de um ou outro personagem" (RABATEL, 2000, p. 209) 52 . Trata-se de uma maneira de narrar os acontecimentos, ou seja, a partir da perspectiva de um determinado personagem. Este toma, provisoriamente, o lugar do locutor-narrador, sem dispor de um quadro enunciativo particular, isto é, o focalizador percebe, pensa, falando (narrando). Contrariamente, no PDV representado o próprio personagem é a origem da instância focalizante, isto é, o focalizador percebe e pensa sem falar (Ibid., pp. 222-3). Rabatel apresenta um grande número de exemplos, em que a marca linguística é bastante variada (determinante possessivo, demonstrativo, etc.). Vale salientar que, segundo o autor, esse fenômeno não é restrito ao texto do tipo narrativo. Ele também está presente em textos argumentativos (lbid., p. 212).

\section{O PDV ASSERTIVO}

O último PDV proposto pelo autor é o assertivo. Segundo Rabatel, esse PDV indica que o locutor é a origem da percepção por estar mais ligado à ideia de tese ou expressão de um ponto de vista pessoal ou coletivo. Nesse sentido ele é "assimilável à noção de opinião manifestada" (Ibid., p. 226) ${ }^{53}$, em que se expressam valores, crenças e "todas coisas que remetem fortemente para códigos culturais, hábitos sociais e de valores" (Ibid., p. 227) ${ }^{54}$ e desse modo, se presta bem aos textos de caráter argumentativo, mas nada impede de se apresentar em outros tipos de textos, como na argumentatividade do texto narrativo. Neste caso, O PDV assertivo está nas falas dos personagens ou nos julgamentos do narrador.

\footnotetext{
51 "l'attitude du locuteur à l'égard des protagonistes de l'événement: ce phénomène consiste plus précisément à présenter des informations à partir d'un des acteurs de l'énoncé".

52 "adopte le point de vue de l'un ou l'autre personnage".

53 "assimilable à la notion d'opinion manifestée".

54 "toutes choses qui renvoient fortement à des codes culturels, des habitus sociaux et des valeurs".
} 
Segundo o autor, há alguns pontos comuns entres esses PDVs: (a) algum valor enunciativo e pragmático; (b) separação entre enunciador e locutor em suas construções; e (c) participação na construção de uma subjetividade, de julgamentos de valores, escondidos ou mostrados. Nesse sentido, todos eles têm finalidade argumentativa.

Em Rabatel, PDV é definido como "tudo isso que, na referenciação dos objetos (do discurso), revela, de um ponto de vista cognitivo, uma fonte enunciativa particular e que denota, direta ou indiretamente, seus julgamentos sobre os referentes" $(2003, \text { p. } 1)^{55}$. Trata-se de uma definição pertinente para o fenômeno que quero investigar nas redações, porque, desse modo, o PDV não se limita exclusivamente à expressão das percepções, mas remete a referenciação do focalizado a uma dimensão axiológica. Nessa direção, o autor extrapola o campo da narratologia. Rabatel destaca a ambivalência desses PDVs, diante da possibilidade de presença em textos não narrativos. Salienta que essas especificidades não se esgotam no que se refere aos estudos do PDV.

Em trabalhos posteriores, o autor abre um leque ${ }^{56}$ de estudos relacionados ao PDV, numa abordagem enunciativa e interacional, inclusive estudos voltados para a perspectiva da Análise do Discurso; tratando, notadamente, de temas como dialogismo, polifonia, discurso relatado, argumentação.

Para finalizar o estudo do PDV em Rabatel, vale lembrar que, em seus estudos mais recentes, aborda esse fenômeno da perspectiva da teoria da enunciação e da Análise do Discurso. Insiro, nessa discussão, o que o autor entende por multiplicidade de vozes, bem como a noção de hierarquização de PDVs. Rabatel (2004a) opõe o conceito de dialogismo em Bakhtin ao de polifonia de Ducrot, aproximando a noção de dialogismo ao conceito de heterogeneidade constitutiva de Authier-Revuz. Desse modo, tratar do fenômeno da construção de PDVs é igualmente tratar de dialogismo e de heterogeneidade. Na construção de PDVs, então, essas noções podem ser tomadas como sinônimas, na compreensão da multiplicidade de vozes presentes nos enunciados e da tomada de posição pelo

\footnotetext{
55 "tout ce qui, dans la référenciation des objets (du discours) révèle, d'un point de vue cognitif, une source énonciative particulière et dénote, directement ou indirectement, ses jugements sur les référents".

${ }^{56}$ Refiro-me aos inúmeros artigos publicados pelo autor sobre a temática do PDV. Muitos deles podem ser baixados do site do autor, no endereço: < http://icar.univ-lyon2.fr/membres/arabatel/ >.
} 
escrevente. Além disso, há que se considerar que essa tomada de posições também é resultado do cruzamento de discursos, isto é, do interdiscurso. As posições enunciativas estabelecem certa hierarquização de enunciadores - PDVs - que se desdobram discursivamente ao construir um enunciado argumentativo.

É interessante ressaltar que Rabatel, no decorrer de seus estudos, ultrapassa sua própria caracterização de PDV: primeiro, aquela bipartida, PDV do narrador e do personagem; em seguida, a categorização tripartida: PDV representado, narrado, assertivo e, posteriormente, outra classificação também tripartida, coenunciação, subenunciação e sobreenunciação ${ }^{57}$. Conforme dito anteriormente, na definição tripartida de PDV, a distinção entre enunciador e locutor é bem marcada. Para o autor, locutor é o responsável pela enunciação e quem põe em cena, no enunciado, enunciadores, isto é, posições (RABATEL, 2004a). Nesse sentido, podem se aproximar, no que se refere à hierarquização de enunciadores, Ducrot (1987) e Rabatel (2004a, 2004b e outros). Rabatel (2004a, p. 9), ao tratar do "apagamento enunciativo", no discurso citante e discurso citado, estabelece três posturas enunciativas "que entram em jogo na construção interacional de pontos de vista": coenunciação, subenunciação e sobreenunciação. São essas posturas que me interessam nele.

Segundo o autor (2004a, pp. 9-10)

- a coenunciação "corresponde à coprodução de um ponto de vista comum e dividido", ou seja, a coincidência de posturas;

- a subenunciação "remete à expressão interacional de um ponto de vista dominado, em proveito de um sobreenunciador";

- a sobreenunciação "é definida como a expressão interacional de um ponto de vista sobreposto cujo caráter dominante é reconhecido por outros enunciadores", isto é, a dominação de um PDV sobre outro.

\footnotetext{
57 Coénonciation, sousénonciation, surénonciation.

${ }^{58}$ A coenunciação "correspond à la coproduction d'un point de vue commun et partagé";

A subenunciação "renvoie à l'expression interacionnelle d'un point de vue dominé, au profit d'un surénonciateur";

A sobreenunciação "est définie comme l'expression interactionnelle d'un point de vue surplombant dont le caractere dominant est reconnu par les autres énonciateurs".
} 
Essas posturas enunciativas se marcam no texto tanto na diversidade de PDVs quanto em suas hierarquizações e não se confundem com as posições do sujeito falante (2004a, pp. 1-11). Diante dessas colocações, tentarei definir, no âmbito da pesquisa, como vejo a noção de ponto de vista.

\section{PDV E DOMINÂNCIA ENTRE PDVS PARA A INVESTIGAÇÃO DE UM OBJETO DE ESTUDO PARTICULAR}

A construção de PDVs na organização do texto pode ser vista como movimentos de posicionamentos. Essa construção se dá por meio do jogo entre enunciadores, que são hierarquizados a fim de estabelecer uma dominância.

Neste trabalho, defendo que a dominância pode ser detectada por meio da adjetivação e da modalização, articuladas com a mobilização de saberes, isto é, pelo modo de qualificar e pelo tipo de saber que é mobilizado e de onde ele é mobilizado para fazer valer o posicionamento do escrevente.

Há três movimentos possíveis de posicionamentos. O escrevente, para validar seu posicionamento, busca, na própria coletânea e fora dela, saberes de autoridade para: (1) solidarizar-se a ele; (2) refutá-lo; ou (3) não se posicionar diante dele. Esses movimentos de posicionamentos que remetem ao que estou chamando de construção de PDVs dominante são constituídos no enunciado, numa relação dialógica, ou seja, de interação do escrevente em diferentes aspectos: interação entre escrevente e texto, entre escrevente e seu outro e entre discursos.

Dessa interação resultam representações do escrevente, que constrói uma imagem de si e uma imagem do outro, seu interlocutor; uma imagem que o outro vê de si, ou que quer que dele seja vista. Na construção dessas imagens o escrevente assume determinadas posições, PDVs. A construção do PDVD, na organização textual dos enunciados, é moldada a partir dessas representações, que são mediadas pelas condições de produção, ou seja, pela dimensão social do enunciado e pelo caráter histórico das práticas discursivas.

Minha preocupação é buscar os efeitos de sentidos dos diferentes PDVs presentes nos enunciados e sua relação com os saberes mobilizados. Abordar a redação de vestibular por esse caminho pressupõe, igualmente, buscar a orientação argumentativa presente nos textos. Desse modo, se me preocupo com os diferentes 
PDVs e com a argumentação, não se pode deixar de considerar, nessas duas instâncias, o jogo de diferentes vozes presentes nos enunciados das redações. Vozes que concorrem ou que coadjuvam; vozes que se sobrepõem ou que se subpõem. Nesse contexto, quando falo em PDV não estou no plano da opinião, mas na busca dos posicionamentos enunciativos presente nas redações. PDV não se confunde com a opinião do escrevente enquanto sujeito empírico, que, como afirma Ducrot (1987), ganha, na enunciação, o estatuto de ser de discurso. É, pois, ao assumir essa posição enunciativa que o escrevente pode assumir, também, diferentes posições, os diferentes enunciadores que concorrem entre si na constituição dos sentidos do enunciado.

Nessa circulação de enunciadores, os sentidos fluem por fios, como em uma teia, fogem ao controle do sujeito empírico porque eles se inscrevem na história. Desse modo, os efeitos sentidos do enunciado deslizam entre a figura enunciativa do escrevente e a do leitor e se constituem, portanto, a partir desse espaço construído pelo texto. Esse deslizamento se dá ora pelos movimentos de controle pelo escrevente (ou, pelo menos por sua tentativa), ora por seus movimentos de deriva, em que o sentido the escapa sob o domínio de outrem. Observar os diferentes PDVs privilegia um olhar para esse movimento dos sentidos.

Quando, nos enunciados, diferentes PDVs ecoam, há, naturalmente, sobreposição de vozes. Por isso, quando me refiro a PDVD, não quero dizer que há unicidade, um tom monocórdico. Refiro-me, ao contrário, ao trabalho do escrevente, que, por meio de um enunciador dominante, se sobrepõe às demais vozes presentes.

Nos textos sob análise, estudo a construção do PDVD e sua articulação com a mobilização de saberes. Se, por um lado, tratar da questão do PDV direciona a investigação para uma abordagem do gênero redação de vestibular na perspectiva enunciativa; por outro, articular essa questão com a da mobilização de saberes direciona-a para desdobramentos discursivos. Abordar o texto a partir da articulação entre essas perspectivas é buscar definir, nele, as relações do escrevente e de seu outro; mas é, também, buscar no dito o já-dito. Desse modo, busco pistas linguísticas que, na construção do PDVD, evidenciem na redação de vestibular o trabalho do sujeito, o escrevente. As pistas linguísticas podem ser várias, mas 
direciono meu olhar para as qualificações - adjetivações e modalizações - vistas como estratégias argumentativas dessa construção.

\subsection{A qualificação como estratégia argumentativa na construção de PDVs}

Tomo como objeto de análise os qualificadores que, analisados na perspectiva enunciativo-discursiva, tornam-se lugares privilegiados para a identificação e descrição dos posicionamentos assumidos pelo escrevente. Eles fornecem ferramentas importantes para compreender o jogo discursivo nas redações de vestibular. Assim, assumo os qualificadores não numa abordagem formal da língua, posta pela gramática normativa, mas como elementos do discurso, como matizes avaliativos, ou seja, os qualificadores, em sua carga enunciativa e discursiva, que se manifestam nos enunciados por meio do modo pelo qual o escrevente exprime seu(s) ponto(s) de vista. A qualificação é vista, portanto, neste estudo, de forma ampla, e não se refere à adjetivação formalizada pela gramática tradicional. Até porque, de acordo com Perini (2000, p.42), adjetivos e substantivos são duas classes de palavras "extremamente difíceis de distinguir". Para o autor, o que seria mais correto é definir o comportamento gramatical da palavra em seu uso, isto é, de acordo com sua função (PERINI, 2000, p. 45).

À parte essa caracterização ampla da qualificação, vista, em geral, como marca de subjetividade, é importante lembrar que a subjetividade é inerente à linguagem e, segundo Kerbrat-Orecchioni (2002, p. 79, grifos da autora), "toda unidade lexical é, num certo sentido, subjetiva, já que as 'palavras' são apenas símbolos substituíveis e interpretativos das 'coisas'”. Nesse sentido, qualquer palavra enunciada carrega em si a subjetividade. Alguns lugares de sua inscrição são mais sutis; outros, mais fortes, porém, em todos eles os PDVs estão presentes. A construção de PDVs pode ser representada por diferentes aspectos formais do texto, manifestando o caráter heterogêneo dos enunciados:

O discurso mostra essa heterogeneidade através de marcas explícitas, como a negação e o discurso relatado em que se delimita de forma clara a alteridade discursiva; mas nem sempre o caráter heterogêneo da interação enunciativa tem marcas visíveis que uma abordagem linguística stricto sensu possibilite apreender (BRANDÃO, 1997, p. 71). 
O que chamo de qualificação não se restringe à adjetivação simplesmente, mas a tudo o que pode caracterizar, avaliar, valorar o referente. Nesse sentido, podem-se analisar os adjetivos, locuções adjetivas, orações adjetivas, mas também um substantivo, verbo ou um advérbio em que o tom expressivo-valorativo qualifique o referente e funcione como estratégia argumentativa na construção de pontos de vista. O tom expressivo-valorativo pode ser avaliativo no sentido de caracterizar um julgamento de valor ${ }^{59}$, uma comparação ou uma intensificação pelo escrevente. Toda qualificação é carregada de valores, e esses valores não são fixos, são, ao contrário, graduais, variando do mais objetivo ao mais subjetivo; do mais pejorativo ao mais apreciativo. Essas graduações avaliativas não dependem da palavra em si, por isso não estão presentes somente nas qualificações; elas estão diretamente vinculadas ao contexto de enunciação. Os sentidos das palavras não estão nelas mesmas, mas são construídos na interação (BAKHTIN, 1986). Um termo aparentemente neutro pode se axiologizar (KERBRAT-ORECCHIONI, 2002, p. 85) e se estabelecer na interação carregado de determinados valores. Esse investimento axiológico, segundo a autora, é muito instável e está condicionado à "diversidade das competências ideológicas que eles refletem" (KERBRAT-ORECCHIONI, 2002, p. 86), bem como aos tipos de discursos. Por exemplo, em um discurso polêmico, a probabilidade da presença de termos axiológicos seria muito maior do que num discurso em que predomina a descrição.

No que se refere à modalização/ modalidade, ela é vista na articulação com a adjetivação, constituindo um bloco de qualificação no enunciado. Essa articulação é necessária porque os modalizadores "são igualmente importantes na construção do sentido do discurso e na sinalização do modo como aquilo que se diz é dito" (KOCH, 1998, p. 47, grifos meus). A modalização é vista pelos estudiosos sob diferentes aspectos, alguns mais amplos, outros mais restritos. Explicito as diferentes modalizações, buscando conceitos em alguns autores, mas centralizo a discussão em Neves (2000) por considerar mais abrangente seu estudo e, principalmente, por abordar os modalizadores em uso concreto da língua.

Ao analisar o gênero redação de vestibular (isso vale também para outros gêneros) partindo da perspectiva enunciativo-discursiva, abre-se um leque enorme

${ }^{59}$ A expressão julgamento de valor, segundo Rousselet-Ferrando (2005, p. 76), foi utilizada pela primeira vez pelos Neo-kantianos no início do século XX, em torno de Max Weber, a partir da sua distinção entre "julgamento de fato" (objetivo) e "julgamento de valor" (subjetivo). 
de possibilidades para analisar a construção de pontos de vista, partindo da qualificação estabelecida pelas adjetivações e modalizações presentes nos enunciados das redações.

$\mathrm{Na}$ redação de vestibular, por tratar-se de um gênero em que predomina o tipo textual dissertativo-argumentativo, o tom expressivo-valorativo é mais marcado nas escolhas do escrevente. Para Kerbrat-Orecchioni, toda escolha organiza-se em dois tipos de formulações: o discurso objetivo e o discurso subjetivo. Não se trata de polos opostos e marcados pela dicotomia, mas de uma gradação (KERBRATORECCHIONI, 2002, p. 81):

OBJETIVO

SUBJETIVO

$\begin{array}{lll}\text { Solteiro jovem } & \text { bequeno }\end{array}$

Essa gradação "se constitui na relação existente entre o objeto percebido e 0 sujeito percebedor" (KERBRAT-ORECCHIONI, 2002, p. 81). Além disso, segundo Bakhtin (2003), a relação de construção de sentido não é da palavra e não é um dueto apenas entre objeto percebido e sujeito percebedor, mas um trio que estabelece um dialogismo mais amplo:

A palavra não pode ser entregue apenas ao falante. $O$ autor (falante) tem os seus direitos inalienáveis sobre a palavra, mas o ouvinte também tem os seus direitos; têm também os seus direitos aqueles cujas vozes estão na palavra encontrada de antemão pelo autor (BAKHTIN, 2003, p. 328).

Para Bakhtin, o enunciado se constitui dialogicamente, isto é, "não é determinado por sua relação apenas com o objeto e com o sujeito-autor falante [...], mas imediatamente, [...] com outros enunciados no âmbito de um dado campo de comunicação." (BAKHTIN, 2003, p. 328). A compreensão do enunciado envolve, segundo o autor, responsividade e juízo de valor. O efeito de sentido é dado na interação entre o sujeito que enuncia e o sujeito receber da enunciação, ou seja, o sentido não está na unidade lexical em si, mas nesses espaços interativos. Apesar de algumas unidades lexicais carregarem em si certa carga valorativa, como os adjetivos belo ou precioso, o substantivo maldição, dentre outros, é na interação do um com seu outro/Outro que se constituirá efetivamente determinado efeito de sentido. O sentido não está na palavra, mas nas relações dialógicas de um 
enunciado. Ao analisar as redações, busco, como dito anteriormente, o modo como o escrevente constrói PDVs e, nesse sentido, é importante na análise que esse modo está relacionado com a interação entre interlocutores, ou seja, a determinação dos papéis sociais desempenhados por esses interlocutores, mas igualmente com a relação com tudo o que já foi dito, com tudo aquilo que circula no interdiscurso.

Nessa direção, os termos exemplificados acima (belo, precioso, maldição), dentre outros, podem exprimir tanto uma carga valorativa apreciativa ou valorativa depreciativa, a depender do modo pelo qual são enunciados. E esse modo de enunciar é condicionado pelas condições de produção do discurso. Isso significa considerar não só os interlocutores, mas todo um conjunto de elementos envolvidos na enunciação de um discurso. Dessa maneira, o uso de um mesmo termo pode surtir efeitos de sentidos totalmente opostos, em função do modo pelo qual ele é enunciado. O enunciado é, assim, resultado de um processo dialógico, em que diferentes marcas linguísticas expressam a subjetividade. Por isso não me fixo apenas na adjetivação, mas também nas modalizações resultantes do uso de alguns substantivos, advérbios ou mesmo de alguns verbos que, por sua vez, emolduram a construção de pontos de vistas. A importância em analisar a adjetivação e a modalização, num gênero discursivo específico, não está nelas em si, ou seja, nesses subjetivemas ${ }^{60}$, mas no todo que envolve a busca da construção de pontos de vistas por meio da análise de um gênero discursivo, isto é, de um enunciado concreto.

Não me prendendo às noções mais formais da gramática normativa, busco, efetivamente, algumas classificações e definições mais discursivas em Neves (2000), caracterizadas pelos usos e em Kerbrat-Orecchioni (2002), segundo as características da subjetividade na linguagem. Num primeiro momento, trato das adjetivações para, em seguida, tratar das modalizações e finalizar com a articulação entre elas e sua importância na construção de PDVs.

60 Subjetivemas são, segundo Kerbrat-Orechionni (2002, p. 93), lexemas que caracterizam a enunciação subjetiva, podendo reconhecer neles os juízos avaliativos valorizantes ou desvalorizantes do enunciador. 


\subsection{A adjetivação}

Para Neves (2000), os adjetivos dividem-se em qualificadores e classificadores. Os qualificadores "indicam, para o substantivo que acompanham, uma propriedade que não necessariamente compõe o feixe de propriedades que 0 definem" (NEVES, 2000, p.185, grifo da autora). Isso implica, segundo a autora, maior ou menor grau de subjetividade dos adjetivos, que passam por um processo de predicação. Os adjetivos qualificadores possuem "propriedades ligadas ao próprio caráter vago que se pode atribuir à qualificação" (NEVES, 2000, p. 186), podendo ser graduáveis e intensificáveis. Além disso, a autora propõe a organização dos adjetivos qualificadores segundo seus valores semânticos (NEVES, 2000, p. 188ss.), dentre eles destaco o de modalização:

a.1) epistêmica (de certeza, de eventualidade): quando exprimem conhecimento ou opinião (é evidente; é provável); e

a.2) deôntica, em que exprimem consideração de necessidade por obrigatoriedade (é necessário);

Os adjetivos classificadores, para Neves (2000, p. 186, grifos da autora), "colocam o substantivo que acompanham em uma subclasse, trazendo em si uma indicação objetiva sobre essa subclasse. Eles constituem, pois, uma verdadeira denominação para as subclasses, e, portanto, são denominativos, e não predicativos, possuindo um caráter não-vago".

Segundo Neves (2000, p. 199), é possível a transformação entre tipos de adjetivos, isto é, os classificadores podem passar a qualificadores e vice-versa. A autora trata, ainda, da posição dos adjetivos (p. 200-212): posposta, a menos marcada; e anteposta, mais marcada e, por isso, proporciona grande efeito de sentido, principalmente o de maior subjetividade, reforçando o caráter avaliativo presente na qualificação. Nos adjetivos de avaliação, verifica-se mais facilmente o grau de envolvimento do falante na qualificação, obtido pelo efeito de conotação com a anteposição do adjetivo (desagradável cheiro). Contrariamente, os adjetivos de intensificação são mais denotativos, indicando menor envolvimento do falante na intensificação. De modo geral, a anteposição do adjetivo reforça a atitude valorativa da qualificação. Além disso, a posição que ocupam no sintagma também provoca efeitos de sentidos característicos: 
A ordem dos termos é um aspecto de máxima relevância para a feição estilística da frase e do texto, visto que determina o ritmo e a valorização de idéias e sentimentos, propiciando efeitos variados [...]. De modo geral, coloca-se antes do substantivo o adjetivo que exprime valor apreciativo (uma bela idéia, uma comovente dedicação) e coloca-se depois o adjetivo que enuncia particularidade que caracteriza o objeto, definindo-o, distinguindo-o de outros, classificando-os (homens ignorantes, fama internacional, tecidos finos, música clássica) (MARTINS, 2000, p. 164-5).

Apesar desses efeitos de sentidos relacionados à posição do adjetivo no sintagma, há outros fatores importantes na construção de sentidos, por exemplo, a natureza do discurso. Desse modo, não se pode caracterizar a qualificação isoladamente. Deve-se observar a que o escrevente dá especial atenção em sua avaliação do objeto de discurso.

Há ainda, os adjetivos formados por sintagmas cristalizados, resultando numa unidade lexical, como, ser humano, por exemplo, em que a adjetivação, em virtude da cristalização, é mais apagada.

Kerbrat-Orecchioni (2002) faz um longo estudo de diferentes subjetivemas, tendo como eixo a subjetividade na linguagem e a tomada de posição pelo escrevente. Em sua obra, a autora prioriza os matizes avaliativos, axiológicos e afetivos dos subjetivemas, desvelando diferentes formas da subjetividade nos discursos e sua estreita relação com a construção argumentativa do discurso. Nesse sentido, trata-se de um estudo muito proveitoso para a caracterização da construção de PDV por meio da análise da qualificação.

A fronteira entre os subjetivemas mais objetivos e os mais subjetivos não é fixa, porque "os termos subjetivos portam um valor informacional suplementar, que não concerne somente ao objeto em que se fala, mas também à pessoa do locutor" (KERBRAT-ORECCHIONI, 2002). Para a autora, os subjetivos, que dependem de um julgamento por parte do escrevente, classificam-se em três categorias: afetivos, avaliativos (axiológicos e não-axiológicos) e modalizadores (2002, p. 81). Os afetivos concernem aos sentimentos do locutor e refletem uma emoção; os avaliativos axiológicos refletem uma avaliação em relação a um julgamento de valor e os avaliativos não-axiológicos refletem uma avaliação em relação a norma; os modalizadores refletem a atitude do locutor em razão do conteúdo proposicional. Já os objetivos descrevem uma realidade. A autora propõe a seguinte classificação: adjetivos objetivos (solteiro, casado, adjetivos de cor, etc); adjetivos subjetivos: 
afetivos (alegre, patético), avaliativos não-axiológicos (grande, distante); avaliativos axiológicos (bom, bonito) (cf. KERBRAT-ORECCHIONI, 2002, p. 94).

Os objetivos não necessitam de uma avaliação de um julgamento de valor. Se se diz, fulano é solteiro, trata-se de uma descrição por meio de uma constatação da situação desse sujeito. Eles descrevem o referente sem necessidade de um julgamento e, nesse sentido, são menos marcados pela subjetividade.

Segundo Kerbrat-Orecchioni (2002), os adjetivos considerados avaliativos estão diretamente relacionados com a competência cultural e ideológica do locutor e refletem mais marcadamente sua subjetividade $e$, consequentemente, seu posicionamento, constituindo um PDV marcado. Eles apresentam-se em graus variados de subjetividade, e esses graus estão condicionados ao contexto de uso. Os axiológicos são os mais marcados; há uma atribuição de julgamento de valor, afetivo ou avaliativo. Já os não-axiológicos são mais descritivos.

Assumir a adjetivação nessa perspectiva corrobora o aspecto dialógico da linguagem, situando os elementos qualificadores como um lugar privilegiado para a manifestação da subjetividade. Segundo Bakhtin:

O segundo elemento do enunciado, que lhe determina a composição e o estilo, é o elemento expressivo, isto é, a relação subjetiva emocionalmente valorativa do falante com o conteúdo do objeto e do sentido do enunciado. [...] um enunciado absolutamente neutro é impossível. A relação valorativa do falante com o objeto do seu discurso (seja qual for o objeto) também determina a escolha dos recursos lexicais, gramaticais e composicionais do enunciado. $O$ estilo individual do enunciado é determinado principalmente pelo seu aspecto expressivo (2003, p. 289).

Ao responder aos enunciados - atitude responsivo-ativa - o escrevente assume um posicionamento marcado por tom expressivo, que estabelece certa orientação argumentativa ao enunciado. Desse modo, a adjetivação é vista não só pelo que ela qualifica, mas pelo modo como ela qualifica.

Nessa direção, a adjetivação tem um lugar privilegiado para a constituição de PDVs, e, muitas vezes, trata-se de uma heterogeneidade mostrada e marcada e evidencia a alteridade inerente ao enunciado. As relativas, por exemplo, possibilitam a articulação entre dois enunciados, em que PDVs podem ser estabelecidos em concordância ou não entre eles. O PDV da proposição que carrega a relativa pode endossar (ou não) um mesmo PDV, a depender da direção argumentativa dada pelo 
escrevente. Por exemplo, no uso de uma sequência de relativas explicativas é dada determinada orientação argumentativa que remete a postura do locutor de sobreenunciador e, nesse sentido, um PDV dominante é construído. A função da reincidência de relativas é ratificar o PDV que está em construção, contribuindo para uma construção dominante de um PDV.

\subsection{A modalização}

A definição de modalização não é uniforme nos vários autores que a estudam, haja vista a diferenciação ou a sinonímia entre os termos modalização e modalidade. Sabendo que há várias abordagens dessas noções, assumo esses dois termos como de significados distintos, mas complementares e interrelacionados (cf. VION 2003, RABATEL, 2005b, dentre outros).

Segundo Cervoni (1989, p. 53), a noção de modalidade implica, na análise semântica de um enunciado, a distinção entre um dito, também denominado 'conteúdo proposicional' e uma modalidade - um ponto de vista do sujeito falante sobre este conteúdo. Para Castilho \& Castilho (2002, p. 217) ${ }^{61}$, o componente modal da sentença qualifica o conteúdo proposicional (dictum) de acordo com o julgamento do falante (modus) de duas maneiras: (1) a modalidade, estratégia em que o sujeito apresenta determinado conteúdo proposicional na forma assertiva, interrogativa ou jussiva e, (2) a modalização, estratégia em que o sujeito expressa sua relação com o conteúdo proposicional, avaliando sua verdade ou expressando seu julgamento sobre a forma escolhida para a verbalização desse conteúdo. Vê-se que, nessa perspectiva, são indissociáveis o dictum e o modus, principalmente no que se refere à construção de PDVs, conforme afirma Rabatel (2005b, p. 121): "é preciso buscar o ponto de vista não somente no modus, mas também no dictum". Esses termos, bases dos estudos da modalização, foram herdados dos estudos da lógica e, desde Bally $(1951,1965)$, são referência nos estudos da enunciação e, particularmente, da modalização:

A análise dos enunciados em duas partes constitutivas, modalidade e conteúdo proposicional, não é nova: os gramáticos da Idade Média, que a haviam herdado dos gregos por intermédio dos latinos,

\footnotetext{
${ }^{61}$ Nesse artigo, os autores assumem a sinonímia entre os termos modalidade e modalização, entretanto, iniciam o artigo, explicitando, entre eles, a diferenciação que cito.
} 
praticavam-na correntemente. Na época clássica, ela se reflete na distinção entre a forma e a matéria dos enunciados [...]. E Charles Bally faz dela a base de sua 'teoria da enunciação' [...], onde retoma os mesmos termos utilizados na Idade Média: modus e dictum. (CERVONI, 1989, p. 54, grifos do autor).

De acordo com Vion (2003), as modalidades estão no plano do dictum, e as modalizações, no plano do modus. A modalização evidencia o posicionamento do escrevente. Para Dubois (2007, p. 305), a modalização é "o componente do processo de enunciação que permite estimar o grau de adesão do locutor em seu enunciado", sempre necessitando de seu posicionamento em relação ao que diz e como diz. Para Vion (2007, p. 198), a modalização é um comentário reflexivo da inscrição do dictum, isto é, indica o modo como se diz o dito. Nessa mesma direção, Charaudeau e Maingueneau (2006, p. 336), afirmam que a modalização "designa a atitude do sujeito falante ao olhar de seu próprio enunciado". Depreende-se desses autores que a relação entre dito e modus é um processo de construção do enunciado e não diz respeito somente a essa relação dialógica: escreventeenunciado; trata também do processo da enunciação, porque diz também respeito à dialogia entre escrevente e seu interlocutor:

A presença do sujeito enunciador se traduz também em suas marcas de modalização. Dizer, é também se situar em relação a seu próprio dizer. O texto é assim constantemente habitado pela presença de um sujeito que situa o seu dizer em relação ao certo, ao possível, ao provável... (modalidades lógicas), ou que portam julgamentos de valor (modalidades apreciativas). Em todo o caso entretanto não se trata de uma relação solitária entre o enunciador e o que ele diz: o enunciador é sempre tomado em sua relação com seu co-enunciador (MAINGUENEAU, 1991, p. 108).

No processo de enunciação, a dialogia é ampla, e não faz referência apenas ao escrevente, enunciado e interlocutor, inclui-se um processo de construção de PDVs, a partir de imagens e representações construídas pelo escrevente e determinadas pelo evento. Essas imagens são carregadas de valores representativos da ideologia. É nesse espaço, duplamente dialógico, que o posicionamento do escrevente é construído. É um espaço de trabalho do sujeito com a linguagem, marcado pela modalização.

Vários autores tratam da classificação dos modalizadores, abrangendo variadas concepções. Para categorizar o uso da modalização, tomo algumas noções de Castilho e Castilho (2002), de Neves (2000) e de Maingueneau (1991). A 
modalização é materializada linguisticamente de diferentes maneiras, por exemplo, por índices que exprimem caráter alético (de verdade), necessidade epistêmica (conhecimento), possibilidade epistêmica (crenças), caráter deôntico (o normativo, o dever, a obrigação), avaliativo (axiológico ou não-axiológico), afetivo, etc. Esses índices são expressos no enunciado principalmente por meio dos advérbios ou expressões adverbiais, cuja classificação é muito extensa. Vale salientar que esses elementos agem articulados com outros na construção de PDVs, por exemplo, verbos, substantivos e adjetivos, estes, priorizados neste estudo.

Feito esse levantamento de conceitos, para análise baseio-me em Neves (2000), principalmente no que se refere ao uso dos advérbios modalizadores que, para a autora, têm como característica básica a intervenção do sujeito "na definição da validade e do valor de seu enunciado" (p. 24). Trata-se de uma estratégia do escrevente para atingir seu interlocutor. A autora classifica os advérbios modalizadores em quatro subclasses: epistêmicos, delimitadores, deônticos e afetivos. Segundo a autora (NEVES, 2000, p. 237ss), os epistêmicos (asseverativos) "indicam uma crença, uma opinião, uma expectativa sobre a asserção", além disso, por meio deles há uma avaliação do valor de verdade do dito, podendo afirmar, negar ou relativizar seu conteúdo. Os delimitadores demarcam "o ponto de vista sob o qual uma asserção pode ser considerada verdadeira"; circunscreve seus limites, ou tenta limitá-los. Os deônticos referem-se a uma obrigação ou uma necessidade e os afetivos "indicam um estado de espírito do falante em relação ao conteúdo da asserção", esse estado de espírito pode estar relacionado com o sentimento do sujeito ou pode, ainda, demonstrar sua relação com o interlocutor, por exemplo, por meio da expressão de sinceridade, surpresa, franqueza, etc.

A autora trata detalhadamente dos advérbios de modo, que, segundo ela, "constituem a subclasse mais característica dos advérbios, já que eles são qualificadores de uma ação, um processo ou um estado, isto é, modificam propriedades de verbos e adjetivos" (NEVES, 2000, p. 241, grifos meus). Além disso, esses advérbios desempenham a mesma função dos adjetivos qualificadores, podendo ser catafórico, quando é especificado por um sintagma de valor adjetivo. Podem, também, ser derivados de adjetivos qualificadores, quando acrescidos (ou, às vezes, não) do sufixo mente. 
Alguns advérbios em mente compõem os modalizadores epistêmicos asseverativos, e, ao tentar validar algum valor de verdade no enunciado, revelam saberes do locutor. Por meio desses modalizadores, o locutor quer "marcar seu enunciado como digno de crédito" (NEVES, 2000, p. 249). A ocorrência dos modalizadores epistêmicos se dá, algumas vezes, por meio de uma base adjetiva ou por formas de adjetivos gramaticalizados como advérbios, por exemplo, claro, certo, lógico (NEVES, 2000, p. 250).

Há, também, a modalização em que a participação verbal é intensa, no uso, por exemplo, dos verbos modais dever, poder, na locução ter de + infinitivo, verbo ser + adjetivo. Eles modalizam o conteúdo proposicional, expressando necessidade, possibilidade, obrigatoriedade, permissão, certeza, etc. A qualificação é constituída, então, por meio de uma articulação que envolve a adjetivação e a modalização. A categoria de qualificação, verbo ser + adjetivo, é muito presente nos enunciados das redações. Outra possibilidade é por meio de alguns advérbios derivados de adjetivos chamados modais, como certamente, necessariamente, obrigatoriamente. A modalização pode ser vista, assim, como uma estratégia argumentativa.

\subsection{A construção de pontos de vista: "enxergando" as vozes}

A qualificação - adjetivação e modalização, articuladas - pode ser vista, assim, como um trabalho do sujeito com a linguagem. A expressão linguística em que ela se manifesta é variada e pode ser representada como unidade discursiva, em que várias vozes se cruzam (MAINGUENEAU, 1991, p. 127) para constituir um PDVD. A qualificação é, desse modo, um lugar privilegiado para exprimir esse PDV do enunciador.

A materialidade linguística em que se formula a qualificação é tomada de valores, porque expressam avaliações e julgamentos. Esses valores não podem ser tomados aleatoriamente, mas em função da constituição argumentativa do enunciado e que, no caso do gênero em análise, a redação de vestibular, ela é muito presente. A argumentação é complexa e não envolve apenas a adjetivação e a modalização, há outros elementos que contribuem para a argumentatividade. Esse aspecto pode ser dimensionado, por exemplo, no uso da intensificação "em que o 
substantivo da direita atua como qualificador, e, nesses casos, a manifestação da intensificação será evidência de sua função semântica qualificadora, bem como da adjetivação do substantivo: Esse padre é muito HOMEM' (NEVES, 2000, p. 176, grifos da autora). Esse mesmo posicionamento tem Kerbrat-Orecchioni $(2002,88)$ : ao tratar do funcionamento de termos axiológicos na construção da ironia, por exemplo, afirma que não se pode deixar de "considerar os efeitos por vezes indiretos do cotexto por vezes amplo, e da dinâmica argumentativa na qual eles se encontram tomados". Nessa direção, tomo a qualificação como estratégia argumentativa construída na articulação entre diferentes elementos que contribuem para o estabelecimento da qualificação do objeto do discurso para construir PDVs.

Há que se considerar, nesse contexto, as expressões avaliativas e de julgamentos importantes para depreender de que modo a qualificação é tomada de valores ideológicos e quais suas implicações na construção do PDVD. Isso porque, na situação de enunciação em que se encontra o escrevente, uma avaliação para acesso ao ensino superior, há um conjunto de valorizações impostas pela instituição ou mesmo pela própria sociedade, por exemplo, as capacidades desejáveis para um candidato ao ensino superior ser aceito pela universidade.

Os dizeres que marcam o posicionamento do escrevente são tomados de valores ideológicos construídos em função de sua vivência, de sua formação sóciohistórica, ou seja, de seus letramentos. A partir desses ditos, dois discursos estereotipados circulam nos dizeres desses escreventes. Trata-se de discursos de formações discursivas conflitantes: uma, que valoriza o trabalho; outra, que o deprecia. Emolduram-se, assim, representações diversas do trabalho e, nelas, a ideologia é materializada e PDVs são estabelecidos, posicionamentos são firmados. Reforça-se, assim, a ideia de que nada é neutro no discurso. Isso porque, segundo Fiorin (2002a, p. 29), a ideologia "é uma 'visão de mundo', ou seja, o PDV de uma classe social a respeito da realidade, a maneira como uma classe ordena, justifica e explica a ordem social". Para o autor, numa formação social, as visões de mundo são tão numerosas quanto as classes sociais e "a ideologia dominante é a ideologia da classe dominante" (FIORIN, 2002a, p. 31). Essas visões não são escolhas do escrevente, suas representações são determinadas a partir das relações sociais e do papel social que ele ocupa. Há, nesse sentido, sobreposições de discursos em que um tenta ser o dominante, sobrepondo determinada formação discursiva sobre 
outra, ou outras. São discursos tomados por vozes diferentes que concorrem entre si. A ação do sujeito sobre a linguagem é de dotar seu enunciado de contorno de valores para tornar válido o seu dizer, isto é, para legitimar seu PDV. Essa legitimação é determinada pela formação discursiva e ideológica em que o escrevente está inserido. Qual discurso prevalece no final?

Há que se lembrar de que não existem ideias fora dos quadros da linguagem, por isso, "a cada formação ideológica corresponde uma formação discursiva, que é um conjunto de temas e de figuras que materializa uma visão de mundo" (FIORIN, 2002a, p. 32).

A produção escrita do vestibulando é, assim, tomada por representações, por imagens construídas e determinadas pela situação de enunciação. Buscar o PDVD nas redações, isto é, as posturas do escrevente, é buscar a formação discursiva que domina e determina o seu discurso, uma vez que ela também é fruto de seu posicionamento. Além disso, ao considerar que o discurso não pode ser mais visto de fora de suas condições de produção, é preciso saber de que modo o exterior influencia o interior do discurso. A redação de vestibular está inscrita em condições de produção bastante específicas. Trata-se de um espaço discursivo restrito, em que as relações de dominação são bem demarcadas. Quem detém o poder é o interlocutor privilegiado, o examinador, uma vez que será ele quem dará a palavra final: aprovado ou reprovado. É a ele que se dirige a tentativa de sedução, de convencimento, de modo a mostrar que o examinando está apto para ingressar no ensino superior, porque suas respostas revelariam competências necessárias para isso.

Mesmo no interior desse jogo de representações ou até mesmo em função dele, a carga subjetiva é bastante significativa, pois está em jogo a construção de uma posição-sujeito em que um PDV é privilegiado. Trata-se de uma posição enunciativo-discursiva, porque o escrevente necessita mostrar um eu que sabe, que é escritor competente, que sabe argumentar para um outro, o eu-leitor, o examinador, para se deslocar da posição de um eu-candidato para um euuniversitário. Essa construção se realiza discursivamente por meio das imagens construídas pelo escrevente. São imagens ficcionalizadas, mas que não deixam de ser imagens construídas como resultado da relação amplamente dialógica que permeia o gênero redação de vestibular. 
A ficcionalização do gênero, que envolve a ficcionalização dos interlocutores, é constitutiva do acontecimento discursivo que é o exame de redação do vestibular. Buin $(2006$; 2007) tematiza a ficcionalização como recurso didático utilizado para criar uma situação para a produção do texto na escola, por exemplo, a construção de interlocutores ficcionalizados como o pai, a mãe, a irmã quando o professor propõe a produção de um gênero como carta ou bilhete. Segundo a autora (BUIN, 2006, p. 193), "a inadequação da estrutura coesiva [...] vem do fato de o aluno não ter ficcionalizado uma situação de produção". Esse recurso é, pois, constitutivo do exame de redação do vestibular.

A ficcionalização não está desligada do imaginário, que, por sua vez, traz consigo diferentes visões de mundo, diferentes posicionamentos. Não está desligada, portanto, das representações que são construídas no jogo enunciativodiscursivo construído pelo escrevente. A ficcionalização é, assim, um fazer-se representar no texto, representar-se para alguém e de um certo modo. Essas construções são resultados das relações sociais, do desempenho de um papel social do escrevente, a partir do qual toma para si as palavras e ficcionaliza, por meio delas, uma situação real.

As palavras tomadas pelo escrevente não são inteiramente suas, são também palavras do outro/Outro. Amplia-se a relação de alteridade entre o um e o outro/Outro, uma vez que o um se constrói a partir seu outro/Outro e este é construído a partir do um. Reafirma-se, então, a ideia de que o sujeito só se constitui a partir de seu outro. O PDV é também construído a partir desse outro/Outro ou de PDVs correlatos, isto é, o escrevente toma seu interlocutor ficcionalizado como referente para construir PDVs. A construção de PDVs, nesse sentido, é amplamente dialógica porque evidencia a heterogeneidade constitutiva dos enunciados e as representações sociais valorizadas pelo escrevente. O estabelecimento da construção de PDVs se dá, assim, num espaço simbólico em que alguns discursos sobrepõem outros discursos; algumas vozes sobrepõem outras vozes, um PDV sobrepõe outros PDVs, tornando-se dominante.

Há, nos enunciados das redações, um jogo de vozes, de PDVs que são materializados nos textos por meio da adjetivação e da modalização, ambas participantes efetivas da organização argumentativa desses enunciados. Essas 
vozes estão representadas nos enunciados por meio dos diferentes enunciadores, que se hierarquizam para o estabelecimento de uma voz dominante.

Além disso, a sobreposição de discursos evidencia a primazia do interdiscurso que compõe as formações discursivas. Desse modo, a construção de PDVs estabelece vínculo com a atualização da memória discursiva do escrevente, que projeta em seu texto a enunciação. Essa projeção é fruto de coerções sociais presentes no processo de escrita do gênero e, nessa direção, a construção de PDVs é também uma construção ideológica. A construção do PDVD é fruto da ideologia vista, segundo Chauí (2001, p. 108), como

um conjunto lógico, sistemático e coerente de ideias e valores e de normas de conduta que indicam e ordenam aos membros da sociedade o que devem pensar e como devem pensar, o que devem valorizar e como devem valorizar, o que devem sentir e como devem sentir, o que devem fazer e como devem fazer.

O PDVD é moldado, portanto, por coerções sociais. O que faz com que, nos enunciados, um enunciador se sobreponha aos demais, tornando-se sobreenunciador. É nessa instância que se dá a construção do PDVD.

Faço, a seguir, a descrição dos PDVs encontrados nos enunciados das redações. São eles: (A) os PDVs da coletânea, que se dividem em dois posicionamentos antagônicos: um de aproximação do PDV assumido em cada fragmento da coletânea; outro, de recusa, de distanciamento deles. (B) O PDV buscado fora da coletânea, no qual o escrevente busca saberes de enunciados diferentes dos da coletânea e que fazem parte de seus letramentos, mas também de suas representações a respeito do que julga importante fazer transparecer em seu texto. (C) O PDV do destinatário, em que prevalece uma voz institucionalizada, seja na figura da banca examinadora na universidade renomada seja na tentativa de cumprimento de uma tarefa vista como tarefa escolar pelo escrevente. Entram em jogo na construção desse PDV o discurso pedagógico e o institucional. (D) O PDV dominante, que se divide em três posicionamentos, sendo que dois deles são antagônicos e concorrem entre si. Trata-se daquele que vê o trabalho como dignidade do trabalhador, contrário a seus direitos, isto é, aos direitos humanos; aquele que vê o trabalho como exploração do trabalhador, isto é, defensor dos direitos humanos e aquele que vê o trabalho de arte como ideal e, por isso, o tem como modelo a ser seguido por todos os trabalhos. 


\section{A. Os PDVs da coletânea}

Os enunciados da coletânea exibem valores que ora são captados pelo escrevente, ora são recusados por ele. Isto é, o escrevente está diante de duas opções: 1. aproximar-se de um dos PDVs expostos na coletânea, isto é, assumir um PDV ali expresso, ou 2. distanciar-se dos PDVs expostos na coletânea, desconsiderando-os ou opondo-se a eles ou a um deles. Esses posicionamentos poderão ser depreendidos por meio da análise das retomadas que o escrevente faz dos enunciados da coletânea. Nelas, o locutor coloca em cena enunciadores que são responsáveis pela assunção de um ou outro PDV. O escrevente que assume um PDV da coletânea pode defender, com base no primeiro fragmento, a tendência de mudança do trabalho no tempo, seja por sua transformação ou até mesmo por seu desaparecimento, tendência ligada ao fato de que o trabalho foi inventado pelo homem. Com base no segundo fragmento, o escrevente pode defender um PDV, que põe em cena um enunciador que assume o trabalho como divisor de águas (de um lado, os que trabalham muito; de outro, os que não têm trabalho algum). Já se se basear no terceiro fragmento, o escrevente enaltecerá o trabalho com a arte, considerado como processo e resultante de toda uma vida.

\section{B. O PDV buscado fora da coletânea}

Há escreventes que não se detêm nos posicionamentos depreendidos da coletânea e buscam recursos em enunciados outros, trazendo para seu texto outros discursos acerca da relação entre o homem e o trabalho. Trato esse PDV como o trabalho do escrevente com outras esferas, sendo elas: religiosa, profissional, histórica, da saúde, da própria situação de enunciação, dentre outras. A partir dos PDVs buscados nessas esferas, o escrevente constrói o seu, mas mantendo, ainda, forte ligação com a construção do PDVD, porque remetem aos PDVs que apresento no próximo item.

\section{O PDV do destinatário}

O PDV do destinatário é constituído a partir das imagens e representações que o escrevente constrói de seu destinatário e dos valores e posições que ele representa para o escrevente nas condições de produção da redação de vestibular. 
Neste PDV circulam discursos da esfera escolar: o discurso institucional e o pedagógico, vistos como determinantes do posicionamento do escrevente.

O discurso institucional valoriza a chamada alta cultura, o uso da norma culta, os diferentes saberes julgados como os que a instituição valoriza, segundo o escreve e suas representações. No discurso pedagógico, há uma valorização do que foi (ou do que deveria ser) depreendido pelo escrevente como aluno sobre o ensino da escrita e, especificamente, o ensino da redação escolar, isto é, tudo o que foi visto por ele, ensinado para ele sobre o gênero em questão. O escrevente deve responder a esse interlocutor na medida em que participa de um evento específico, uma avaliação por meio da escrita de um gênero.

O PDV do destinatário é construído, portanto, com base no interlocutor presumido e no que é considerado o esperado para o gênero, ou o que o escrevente julga ser esperado segundo o conhecimento que tem das coerções da situação de enunciação, por exemplo, os critérios de correção da prova de redação ou mesmo dos discursos postos pelos professores de língua portuguesa, ao ensinarem redigir para o vestibular. Além disso, deve-se ater ao que é solicitado no enunciado da instrução da prova de redação. A construção desse PDV está relacionada com as práticas escolares do escrevente, das quais prevalece a escrita da redação escolar, vista como modelo de escrita. Como todo enunciado responsivo-ativo, o PDV do destinatário responde a outro enunciado, no caso, mais ao enunciado da instrução da prova do que aos enunciados dos fragmentos da coletânea, o que permite considerar um caráter mais institucionalizado do que os dos demais PDVs.

\section{O PDV dominante (PDVD)}

O PDVD é construído a partir de um dos PDVs expostos, constatáveis nas retomadas da coletânea (mesmo nas indiretas) ou nas de discursos que circulam por outras esferas externas às da coletânea. Assim, o PDVD é construído na correlação com outros PDVs. O escrevente toma um deles como ideal, segundo suas representações. Essas representações se fundam nas imagens que ele constrói de si mesmo, do outro, de sua escrita, do gênero, da situação de enunciação, bem como do próprio tema desenvolvido, o trabalho. O PDVD se constitui, portanto, a partir dessas representações. 
Além disso, o escrevente tem como eixo de direção a projeção de seu destinatário, enquanto banca corretora e como instituição universitária de renome. Diante desse destinatário, deve assumir posições bem marcadas no enunciado. Três posicionamentos diferentes concorrem para a dominância. Alguns escreventes se dividem entre duas posições opostas e bem definidas. Neste caso, na construção do PDVD, têm-se duas formações discursivas conflitantes. Uma, a formação discursiva 1 (F1), cujo discurso defende o trabalho como dignidade do trabalhador e; outra, a formação discursiva 2 (F2), que denuncia o trabalho como exploração do trabalhador.

Em F1, o locutor dá voz ao discurso da ideologia dominante que afirma ser por meio do trabalho que o homem se torna nobre e digno. Trata-se de um discurso em que o lucro prevalece sobre o humano. O que está em jogo nessa formação discursiva é a valorização do trabalho, e não a do trabalhador. Na F2, o enunciador afirma que o trabalho destrói o homem, tirando a sua dignidade de ser humano. Trata-se de um discurso que denuncia a extirpação dos direitos do trabalhador. Insere-se, neste posicionamento, a intenção de fazer valer um discurso que defenda os direitos do trabalhador e do cidadão; que proponha uma sociedade justa e com trabalho para todos; e que denuncie a exploração do trabalhador, como, por exemplo, a imposição de trabalho fora dos limites humanos. Na formação discursiva 2, o que está em jogo é a valorização do trabalhador em detrimento do trabalho.

Nessa mesma direção opositiva, temos outro jogo de posicionamentos concorrentes à dominância, ambos conflitantes porque compactuam formações discursivas opostas. Por um lado, o posicionamento em que o locutor encena enunciadores que convocam o trabalho de arte como o ideal e, exatamente por isso, deve ser visto como modelo de trabalho, uma vez que, por meio dele, vive-se o prazer do trabalho, a realização como ser humano e trabalhador. Por outro lado, o posicionamento contrário a esse, que encena 0 trabalho unicamente como sofrimento do homem, não havendo, por isso, modelos a seguir. Vive-se, nesse caso, a angústia de não ser bem-sucedido. Nesse jogo, entram em cena diferentes enunciadores: o que valoriza o trabalho de arte, em detrimento dos demais e o enunciador que define o trabalho como sofrimento, distanciando-se do trabalhoprazer. 
Esses posicionamentos são bastante recorrentes nos enunciados das redações, como mostrarei na análise. Sua construção está atrelada aos diferentes PDVs levantados do corpus. Cada um dos PDVs levantados se manifesta de diferentes maneiras nos textos analisados, mas podem ser depreendidos por meio da análise da qualificação (adjetivação e modalização), que traz à tona a tensão concorrente e coocorrente entre os discursos que fundam esses PDVs. Essas construções são frutos das formações discursivas em que os escreventes estão inscritos. Seus posicionamentos, como mostrarei na análise, nem sempre são exatamente os seus. Trata-se de posicionamentos esperados, segundo julgamento do próprio escrevente, que se fundamenta em suas representações e são determinados pela situação de enunciação e pelos elementos nela implicados.

Serão analisados, da perspectiva enunciativo-discursiva, os elementos da qualificação, isto é, as adjetivações, vinculadas à modalização, mas sempre aquelas tomadas como de maior relevância para evidenciar a construção de PDVs. Procurarei destacar as vozes que falam nos enunciados, vistas como PDVs e que se mostram nos enunciados das redações como enunciadores que se hierarquizam para construir o PDVD. Esses enunciadores enunciam de algum lugar e num determinado momento e são importantes para se depreender um sobreenunciador ou, em outras palavras, para se depreender o PDVD nas redações, isto é, o que se sobrepõe aos demais PDVs. 


\section{CAPÍTULO 3}

\section{A CONSTRUÇÃO DO PDVD E A RELAÇÃO DOS TEXTOS DOS VESTIBULANDOS COM A COLETÂNEA E COM A INSTRUÇÃO}

Neste capítulo, analiso as diferentes formas linguísticas de manifestação de PDVs e descrevo de que modo se processa nas redações a construção do PDVD observado no diálogo entre o escrevente e as fontes diretas de que dispõe para elaborá-las: a coletânea e a instrução.

As redações feitas em situação de vestibular, de um lado, respondem à proposta a ser desenvolvida pelo escrevente, dada pelo exame. Isto é, responde a fatos de cerceamento da dêixis discursiva, considerada em relação ao enunciador, que já vem delineado como um sujeito deôntico: o que deve escrever segundo o tema e o gênero que são impostos como avaliação a ser executada. No outro polo da circunscrição da dêixis discursiva está o destinatário, configurado não só como "banca examinadora" representante da Universidade, mas também como outros interlocutores, por exemplo, o manual de instrução da FUVEST, os professores, a família, a sociedade, de modo geral. Comprimida entre os limites do dever-ser segundo modelos esperados, a enunciação se encontra com poucas possibilidades de variação de modo de presença no mundo, face às coerções genéricas que "são regras que respondem pela especificidade de cada gênero [...] e pela estabilidade do sentido dos enunciados. [...] As coerções genéricas consolidam convenções para o que dizer e como dizer" (DISCINI, 2005, p. 38-9). Submisso ou não a essas coerções, encontro o escrevente trabalhando um dito e um modo de dizer a esses destinatários.

Como procedimentos de análise, busco os tipos de argumentos elaborados pelo escrevente, a fim de caracterizá-los por meio da presença de elementos qualificadores e modalizadores nos textos, detectando a organização argumentativa da redação de vestibular em sua articulação com a construção de PDVs e, especificamente, possibilitando a compreensão do modo como o escrevente constrói o PDVD na organização do texto. 
Ao detectar a organização argumentativa das redações, creio colocar em evidência os movimentos enunciativo-discursivos pelos quais deslizam os posicionamentos do escrevente. Ao buscar os movimentos enunciativo-discursivos, caracterizam-se as condições de produção da redação, destacando-se os lugares sociais marcados no texto e sua relação com a construção do PDVD.

Observo, neste capítulo, o diálogo entre os textos dos vestibulandos tomados em relação aos textos da prova de redação: fragmentos da coletânea e instrução. Os posicionamentos do escrevente são dados nas hierarquizações de enunciadores introduzidos nos enunciados pelo locutor (o escrevente), para corresponder (ou não) aos PDVs depreendidos do diálogo com os fragmentos da coletânea e com as Instruções da prova.

Esses diálogos são analisados em função da hierarquização dos PDVs a partir da escolha de um fragmento privilegiado. O que chamo de privilégio é a resposta, vista como réplica, ao fragmento em questão, dada, principalmente, no parágrafo conclusivo; porém, esse privilégio não se restringe a esse parágrafo, ele também pode estar projetado no todo das redações.

O capítulo está organizado em cinco partes, organizadas segundo os diálogos entre o texto dos escreventes e a ordem dos textos da coletânea e a instrução. No item (3.1) analiso a construção do PDVD a partir da ordem dos textos da coletânea tomada como forma de estruturação do texto, sendo o elemento privilegiado um dos fragmentos da coletânea. Nos itens (3.2) a (3.4) analiso como o escrevente dialoga com a ordem dos fragmentos da coletânea e qual, nessa ordem, é o fragmento privilegiado. Finalizo o capítulo com a análise do diálogo do escrevente com a instrução da prova de redação (3.5).

\subsection{A ordem dos textos da coletânea e a estruturação do texto}

A obediência ao uso da coletânea não se impõe apenas por uma exigência do exame vestibular como forma de avaliar a qualidade de leitura dos candidatos. Para estes, ela pode ser, também, uma forma de facilitar o desenvolvimento temático, como fonte de dados e de argumentos de que o vestibulando pode lançar mão. Não é, no entanto, apenas para o aspecto do conteúdo temático do gênero do discurso que ela contribui. A ordem dos textos da coletânea é, também, com muita 
frequência, utilizada como base para a estruturação do texto, servindo aos vestibulandos como modelo para a construção da estrutura composicional do gênero. Este uso não previsto pelo exame não é, portanto, um aspecto a ser cobrado na avaliação. Pelo contrário, é um recurso facilitador que, se utilizado mecanicamente, dificilmente conduz a um resultado satisfatório. Não deixa de ser interessante, porém, observar a relação que os candidatos fazem entre a disposição espacial dos parágrafos do seu texto e a disposição dos textos da coletânea. Essa leitura da disposição semiótica dos textos da coletânea, de caráter não-verbal, parece contar, portanto, para a estruturação dos textos analisados.

No exemplo [1] ${ }^{62}$, apresento a análise cuja construção do PDVD se dá a partir da ordem dos fragmentos da coletânea tomada como forma de estruturação do texto, sendo um desses fragmentos o privilegiado na redação. Pode-se observar como o escrevente tomou os fragmentos da coletânea, estabelecendo em seu texto a mesma ordem em que eles são apresentados na prova de redação. As retomadas, no exemplo [1], são parafraseadas dos fragmentos da coletânea:

[1]:

O trabalho que Integra

$1^{\circ} \S \mathrm{O}$ trabalho nasceu junto com o homem, pois desde o início de nossa pré-história havia um tipo de divisão de tarefas [...].

2o § É impossível imaginar o mundo atual sem o trabalho assalariado, porque afinal vivemos em um mundo capitalista, onde o lucro é praticamente uma lei cotidiana. [...]. Quem infelizmente não consegue [...] entra para as estatísticas do desemprego [...].

3o § Há também o trabalho que enobrece o homem e engrandece a alma, [...]. Encaixam-se nessa categoria verdadeiros artistas [...].

4 § [faz uma tentativa de síntese, retomando os três fragmentos] $\left(\mathrm{R} 137^{63}\right)$.

O escrevente organiza seu texto em quatro parágrafos e em estreita relação com a ordem estabelecida pelos fragmentos da coletânea. No primeiro parágrafo, faz referência ao surgimento do trabalho. No segundo, trata da sobrevivência por meio do trabalho assalariado e das causas do desemprego. No terceiro, aborda o

\footnotetext{
${ }^{62}$ Por exigência da FUVEST no ato de cessão do material, os exemplos são apresentados por meio de recortes, feitos de tal modo que impossibilitem a identificação dos candidatos. Os exemplos foram transcritos como no original.

${ }^{63} \mathrm{O}$ código refere-se à numeração das redações do corpus, que vai do R001 ao R270.
} 
trabalho de arte. Para concluir, no quarto parágrafo, faz uma tentativa de síntese dos tópicos abordados nesses três parágrafos anteriores.

Essa maneira de organizar o texto é uma tentativa do escrevente de responder a cada um dos fragmentos, tomando os textos da coletânea como questões que solicitam respostas. Nesse sentido, as respostas são réplicas ao enunciado da prova, que inclui os três fragmentos e a instrução da prova. Além disso, essa organização textual denota a tentativa de atendimento, pelo escrevente, às orientações dos professores de redação. Seria uma estratégia do escrevente para utilizar todos os textos que compõem a coletânea. Ele estaria, assim, cumprindo o solicitado na instrução da prova e correspondendo a seu letramento escolar, ou seja, ao que foi aprendido sobre o gênero redação de vestibular. $\mathrm{Na}$ totalidade do corpus, essa organização textual é recorrente e está relacionada com o tipo de leitura e de interpretação da prova de redação.

Nesse mesmo tipo de organização, em que o escrevente trabalha a ordem dada dos fragmentos, pode-se encontrar um modo de adjetivação particular, como o do exemplo [2], que estabelece relação com uma ancoragem temporal:

[2]:

1 $§$ Desde os primórdios da civilizacão humana, [...]. Assim, da forma mais rudimentar o ser humano já havia se sujeitado ao trabalho. [...] essa invenção histórica se tornou intrínseca a nós.

2ㅇ § [...]. No decorrer da nossa história, observa-se a exploração maciça da mão-de-obra o que é um equívoco terrível, [...].

3 § Ademais, podemos inspirarmo-nos no trabalho artístico no qual, muitas vezes árduo e sofrido, há uma entrega descompromissada e uma paixão propulsora de toda a dedicação para a sua concretude. [...].

4 § A rendição pelo trabalho talvez seja uma ilusão - se o considerarmos no contexto da exploração da mão-de-obra na atualidade. Porém o trabalho artístico pode levar-nos aos mais belos prazeres [...] (R079, grifos meus).

No exemplo [2], o escrevente, ancorado na temporalidade do presente da enunciação, coloca em cena enunciadores que manifestam diferentes PDVs sobre o trabalho, introduzidos no texto pelas expressões temporais que expressam a passagem do tempo - "desde os primórdios", "no decorrer da nossa história" - até culminar no presente da enunciação, "na atualidade". Em cada uma delas, o trabalho 
é qualificado de modo singular: na relação com o tempo marcado no texto concomitante à referência a cada um dos fragmentos da coletânea, mantendo a mesma ordem de apresentação da prova de redação. Estão, portanto, presentes, na organização do texto do exemplo [2], dois movimentos: um, que se constitui entre as temporalidades marcadas no texto, e outro, que se manifesta nos modos de adjetivação do trabalho em relação direta com cada temporalidade. Essa organização é resultante do modo como o escrevente lê e compreende os fragmentos e instrução da prova de redação. A partir dessa interpretação, ele toma cada um dos fragmentos da coletânea como uma questão a ser respondida: cada parágrafo de seu texto responde a um dos fragmentos, para responder, de modo geral, ao solicitado na instrução da prova. Esse modo de marcar a interpelação da coletânea reproduz, em alguma medida, as respostas a questionários, exercício escolar muito frequente. Além disso, ele privilegia um dos fragmentos, no caso, o terceiro. O quadro (2) mostra, com mais detalhes, essas relações:

Quadro 2: Comparativo entre a coletânea e uma redação (Exemplo 2):

\begin{tabular}{|c|c|c|c|}
\hline \multicolumn{2}{|r|}{ Coletânea } & \multicolumn{2}{|r|}{ Redação (R079) } \\
\hline $\begin{array}{c}1^{0} \\
\text { fragmento }\end{array}$ & $\begin{array}{l}\text { O trabalho não é uma essência } \\
\text { atemporal do homem. Ele é uma } \\
\text { invenção histórica e, como tal, pode } \\
\text { ser transformado e mesmo } \\
\text { desaparecer. }\end{array}$ & $1^{\circ} \S$ & $\begin{array}{l}\text { Desde os primórdios da } \\
\text { civilização humana, } \\
\text { observamos que essa invenção } \\
\text { histórica se tornou intrínseca a } \\
\text { nós. }\end{array}$ \\
\hline fragmento & $\begin{array}{l}\text { Há algumas décadas, pensava-se } \\
\text { que o progresso técnico e o } \\
\text { aumento da capacidade de } \\
\text { produção permitiriam que o } \\
\text { trabalho ficasse razoavelmente fora } \\
\text { de moda e a humanidade tivesse } \\
\text { mais tempo para si mesma. Na } \\
\text { verdade, o que se passa hoje é que } \\
\text { uma parte da humanidade está se } \\
\text { matando de tanto trabalhar, } \\
\text { enquanto a outra parte está } \\
\text { morrendo por falta de emprego. }\end{array}$ & $2^{\circ} \S$ & $\begin{array}{l}\text { Contudo, quando a força de } \\
\text { trabalho é } \\
\text { brutalmente, [...]. No decorrer da } \\
\text { nossa história, observa-se a } \\
\text { exploração maciça da mão-de- } \\
\text { obra o que é um equívoco } \\
\text { terrível, }[\ldots] .\end{array}$ \\
\hline \multirow[t]{2}{*}{$\begin{array}{l}3^{0} \\
\text { fragmento }\end{array}$} & \multirow{2}{*}{$\begin{array}{l}\text { O trabalho de arte é um processo. } \\
\text { Resulta de uma vida. Em 1501, } \\
\text { Michelangelo retorna de viagem a } \\
\text { Florença e concentra seu trabalho } \\
\text { artístico em um grande bloco de } \\
\text { mármore abandonado. Quatro anos } \\
\text { mais tarde fica pronta a escultura } \\
\text { "David". }\end{array}$} & $3^{\circ} \S$ & $\begin{array}{l}\text { Ademais, [...] trabalho artístico } \\
\text { no qual, muitas vezes árduo e } \\
\text { sofrido, há uma entrega } \\
\text { descompromissada e uma } \\
\text { paixão propulsora de toda a } \\
\text { dedicação para a sua } \\
\text { concretude. [...]. }\end{array}$ \\
\hline & & $4^{\circ} \S$ & $\begin{array}{l}{[\ldots] \text { na atualidade. Porém o }} \\
\text { trabalho artístico pode levar-nos } \\
\text { aos mais belos prazeres. [...]. }\end{array}$ \\
\hline
\end{tabular}


No primeiro parágrafo, o escrevente trata do surgimento do trabalho e de sua importância para humanidade. Para localizar o trabalho nesse vir ao mundo, ele se utiliza da expressão temporal "Desde os primórdios da civilização humana". O uso de expressões temporais desempenha o papel de organizador textual, dando, na articulação entre elas ("No decorrer da nossa história" e "na atualidade"), coesão sequencial ao texto.

Ao utilizar as referências temporais, o escrevente alia o modo de ler e interpretar o que lê ao que escreve, por exemplo, quando faz remissão à invenção do trabalho ou a sua origem. Essa organização temporal, que constrói a coesão sequencial do texto, vem acompanhada de operadores argumentativos (contudo, ademais, porém, respectivamente no $2^{\circ}$, no $3^{\circ}$ e no $4^{\circ}$ parágrafos) que contribuem para dar caráter dissertativo ao relato histórico. O exemplo [2] marca a remissão temporal por meio da expressão adverbial "desde os primórdios da civilização humana", que expressa o surgimento do trabalho em um tempo remoto. 0 escrevente qualifica o trabalho nessa época remota, por meio de uma adjetivação avaliativa, reforçada com intensificador mais: "[...] da forma mais rudimentar [...]", ambos contribuindo para anunciar que, quando surgiu, o trabalho era diferente do que é "na atualidade", mais rude e sem os aparatos da modernidade. Finaliza o primeiro parágrafo, assumindo o mesmo PDV do primeiro fragmento, o trabalho é uma "invenção histórica", e respondendo a esse fragmento sobre a importância do trabalho, ao qualificá-lo como intrínseco: "[...] essa invenção histórica se tornou intrínseca a nós". Para essa qualificação, utiliza-se de uma adjetivação avaliativa dada pela fórmula verbo copulativo + adjetivo. Nesse primeiro parágrafo, como nos seguintes, o escrevente dá uma direção argumentativa para seu texto, articulando as expressões temporais com uma adjetivação bem marcada.

No segundo parágrafo há uma expressão temporal que marca processualmente o passar do tempo: "No decorrer da nossa história". Essa expressão articula-se com a qualificação do trabalho, expressando o mesmo PDV do segundo fragmento, trabalho é exploração. Esse PDV pode ser depreendido na observação da adjetivação bastante marcada no segundo parágrafo da redação, destacada no exemplo [3]:

[3]:

2o § Contudo, quando a força de trabalho é explorada 
brutalmente, está-se agredindo um dom natural do ser, [...]. No decorrer da nossa história, observa-se a exploração maciça da mão-de-obra o que é um equívoco terrível, haja vista conseguir-se uma produtividade maior e melhor comprovadamente - oferecendo-se melhores condições e respeitabilidade (R079, grifos meus).

Como se pode observar, o escrevente qualifica o trabalho com uma adjetivação avaliativa: "dom natural do ser"; e axiológica: "exploração maciça", "é explorada brutalmente", "produtividade melhor", "é um equívoco terrível", "melhores condições". O escrevente depreende o PDV do enunciador do segundo fragmento, inserido na redação por meio da adjetivação, mas não se solidariza com ele, pelo contrário, no modo de adjetivar, expressa um tom de denúncia, contrapondo o PDV do fragmento ao dele, dado pela valorização do trabalho de arte, como demonstra a adjetivação presente no terceiro parágrafo e destacada em negrito no exemplo [4]:

[4]:

3o § Ademais, podemos inspirarmo-nos no trabalho artístico no qual, muitas vezes árduo e sofrido, há uma entrega descompromissada e uma paixão propulsora [...]. Com sua grandeza final, [...] é capaz de fazer com que o sofrimento e a dureza do trabalho [...] seja esquecido e apenas se note a sua formosura (R079, grifos meus).

No exemplo [4] é introduzido um enunciador que hierarquiza os trabalhos e coloca o de arte no topo dos melhores tipos de trabalho. A qualificação do trabalho artístico, nesse exemplo, contrapõe-se aos demais tipos de trabalhos, tratados, no terceiro parágrafo com proposições negativas. Pode-se notar como o trabalho de arte é enaltecido e, apesar de também passar por um processo "árduo e sofrido", como os demais tipos de trabalhos, gera paixão. Além disso, esse enunciador introduz o PDV que valoriza o trabalho de arte não só por meio da adjetivação, mas também pela carga positiva que carregam alguns substantivos e verbos, todos importantes para a construção do PDVD no texto.

$\mathrm{Na}$ conclusão da redação, quarto parágrafo, o trabalho de arte é qualificado como o "salvador", ao ser introduzido um enunciador que o valoriza, porque ele proporciona prazer e não sofrimento e dureza, como os demais tipos de trabalho. Segundo esse PDV, o de que o trabalho de arte "pode levar-nos aos mais belos 
prazeres", o trabalho de arte é modelo para os demais, trazendo equilíbrio entre eles, conforme se nota no exemplo [5]:

[5]:

$4^{\circ} \S[. .$.$] no contexto da exploração [...] na atualidade. Porém o$ trabalho artístico pode levar-nos aos mais belos prazeres. Com isso podemos idealizar um modo de trabalho aceito de forma natural seja o equilíbrio desejado entre o prazer e a obrigação moral (R079, grifos meus).

Há, no exemplo [5], um tom avaliativo-positivo do trabalho artístico que mostra como o PDVD é construído por meio da adjetivação axiológica, fortalecida com a anteposição do adjetivo e o uso de um intensificador, "mais belos prazeres". O próprio substantivo que compõe essa adjetivação carrega também um valor positivo, "prazeres". Além deles, há também o uso de um verbo carregado de valor positivo, idealizar, porque também qualifica o trabalho de arte como ideal.

Destaco do texto (R079), exemplos [02] a [05], a articulação da adjetivação tanto com as expressões temporais como com alguns substantivos e verbos igualmente carregados de valores que marcam a oposição entre o trabalho de arte e os demais tipos de trabalho, como "prazer" e "obrigação/exploração". Há, nesse sentido, um diálogo do escrevente com os fragmentos da coletânea, bem como com sua escrita. As qualificações foram construídas em equivalência não só com a ordem dos fragmentos da coletânea, mas também com base no estabelecimento de um diálogo com os PDVs defendidos em cada um deles. O escrevente privilegia o terceiro fragmento, deixando transparecer sua representação do trabalho e, especificamente, do trabalho de arte.

\subsection{A ordem dos textos da coletânea e a escolha do primeiro fragmento como o privilegiado}

Há duas hipóteses, não-exclusivas, para a escolha do primeiro fragmento da coletânea como base dialógica para o estabelecimento do PDVD. A primeira, ligada à distribuição dos textos na coletânea, cabendo justamente ao primeiro fragmento o lugar mais alto na proposta ${ }^{64}$. O privilégio a ele seria dado em função da premência de obter dados para iniciar a redação e por estar mais à mão. A segunda hipótese,

\footnotetext{
${ }^{64}$ As quantificações são trabalhadas no capítulo 5 , página 201.
} 
ligada ao modo de desenvolver o tema, estaria relacionada ao fato de o primeiro fragmento trazer uma definição para trabalho, lembrada também nas Instruções da prova, o que dispararia, no escrevente, a memória do desenvolvimento temático e da organização argumentativa do texto com base em definições, levando-o a retomar um modelo muito treinado nos cursos preparatórios para o vestibular.

O primeiro fragmento traz posicionamentos distintos e bem marcados em relação à definição de trabalho, a sua transformação e a seu desaparecimento. Quanto à definição do termo "trabalho", o locutor do primeiro fragmento apresenta dois enunciadores com PDVs diferentes. Um PDV é formulado por meio de uma negação, "O trabalho não é uma essência atemporal do homem". Outro, na sequência, é formulado por uma afirmação, "Ele é uma invenção histórica". Ambos são compostos pelo verbo ser - trabalho é, trabalho não é -, constituindo, assim, definições de trabalho. Pelo fato de estarem presentes definições de trabalho no primeiro fragmento, o posicionamento marcado pelo uso da definição de trabalho foi bastante explorado nas redações, principalmente na formulação do primeiro parágrafo das redações.

É verdade que há outro posicionamento bastante recorrente na totalidade do corpus. Trata-se do desaparecimento (ou não) do trabalho, articulado (ou não) com a possibilidade de sua transformação. Muitas vezes, a referência a esse posicionamento serve como recorte para a entrada no tema e, nesse caso, normalmente, tem-se o segundo ou o terceiro fragmentos como privilegiados. Mas voltemos ao privilégio dado ao primeiro fragmento e aos PDVs relacionados a ele.

No primeiro fragmento, reproduzido abaixo, o posicionamento em relação ao trabalho é modalizado por meio da expressão de uma possibilidade, seja de transformação do trabalho, seja de seu desaparecimento:

O trabalho não é uma essência atemporal do homem. Ele é uma invenção histórica e, como tal, pode ser transformado e mesmo desaparecer. [...] (PROVA DE REDAÇÃO, apud FUVEST, 2006, primeiro fragmento da coletânea, grifos meus).

Depreende-se do material analisado que, quando esse primeiro fragmento é o privilegiado, tem-se, principalmente na introdução da redação, referência à definição de trabalho e, na conclusão, a posicionamentos que se marcam em torno do fim ou não do trabalho, exemplo [6]. É recorrente, também, a articulação desses 
posicionamentos com a relevância do trabalho na vida do homem. Por exemplo, se o posicionamento é o de que o trabalho é importante, essencial para a humanidade, admite-se, como consequência, que ele não vai acabar. Neste caso, há, ainda, a referência à possibilidade de transformação do trabalho. Em outras palavras, se o trabalho é exploração, ele deve ser transformado, porque é importante para a humanidade; por isso, deve ser bom para ela e não deve acabar.

[6]:

Impossibilidade

$1^{\circ}$ § Trabalho, hoje em dia, é um conceito que, cada vez mais, parece enraizado na nossa sociedade, [...] diante do sentido atual de trabalho, e sua importância, seria possível viver sem ele atualmente?

20 § O trabalho, nos dias atuais, ganhou uma maior aceleração e necessária dedicação. É preciso desempenhálo com rapidez e eficiência, [...]. o conceito estaria modificado e distorcido em relação ao que era antes, por exemplo no campo artístico, essa distorção mostra o quanto o trabalho está impregnado ao sistema atual, aonde a dedicação e tempo do indivíduo necessitam estarem voltadas para seu emprego [...]. [...].

5 o § Apesar do termo ter sido uma invenção humana o trabalho já está enraizado no nosso tempo, ocupando o tempo do dia-a-dia [...], ficando evidente sua importância contemporânea e a impossibilidade de se viver sem ele (R171, grifos meus).

No exemplo [6], o primeiro fragmento é o privilegiado no diálogo com a coletânea e marca o posicionamento bem definido não só em relação ao fim do trabalho, já destacado no título da redação ("impossibilidade"), mas também no apontamento de sua importância, que é lançada, no texto, a partir de uma pergunta retórica, sendo a resposta a essa pergunta fortemente marcada pela adjetivação.

Ainda no texto R171, exemplo [7], primeiro parágrafo, a retomada do primeiro fragmento da coletânea se dá pela definição de trabalho. $O$ enunciador apresenta um PDV a partir do PDV do fragmento da coletânea, em que o conceito de trabalho é tratado segundo certa dúvida ("parece") quanto à adjetivação ("enraizado") que segue o verbo "parecer". Note-se que a dúvida se realiza mais como uma dúvida pró-assertiva do que propriamente em tom dubitativo, o que talvez se explique pelas relações que o escrevente estabelece entre a redação do vestibular (dissertação) e os gêneros acadêmicos. $\mathrm{O}$ exemplo relaciona, ainda, o trabalho à importância que 
ele teria para o homem e considera, por meio de pergunta retórica com adjetivação epistêmica ("seria possível"), a possibilidade de que ele desapareça:

[7]:

1 § Trabalho, hoje em dia, é um conceito que, cada vez mais, parece enraizado na nossa sociedade, [...] diante do sentido atual de trabalho, e sua importância, seria possível viver sem ele atualmente? (R171, grifos meus).

Esse recorte para entrada no tema proposto funciona como uma estratégia para direcionar a orientação argumentativa e qualificar o trabalho como "enraizado na nossa sociedade". O escrevente passa para o segundo parágrafo, tratando do conceito de trabalho, mas sem definir exatamente o que ele é. No exemplo [8], o escrevente toma o PDV do segundo fragmento, para qualificar o trabalho:

[8]:

2o § O trabalho, nos dias atuais, ganhou uma maior aceleração e necessária dedicação. É preciso desempenhálo com rapidez e eficiência, [...]. O conceito estaria modificado e distorcido em relação ao que era antes (R171, grifos meus).

Pode-se perceber que as primeiras adjetivações são menos contundentes: "maior aceleração e necessária dedicação". Mas entra em cena um enunciador que faz uso novamente da adjetivação deôntica, "É preciso", e a vincula a alguns substantivos carregados de valores: "rapidez", "eficiência". Nessa articulação, o trabalho é qualificado como "modificado e distorcido", isso comparado a um tempo anterior, que não é especificado na redação. Na sequência desse mesmo parágrafo, outro enunciador é encenado para se referir ao trabalho de arte, e apenas nesse momento, uma vez que o fragmento privilegiado é o primeiro e não o terceiro:

[9]:

[...] por exemplo no campo artístico, essa distorção mostra o quanto o trabalho está impregnado ao sistema atual [...] (R171, grifos meus).

A qualificação do trabalho ainda é mantida, com uma adjetivação sinônima da posta no primeiro parágrafo e formulada, agora, com um PDV afirmativo, "está impregnado" e não mais como no primeiro parágrafo, em que o enunciador não tinha certeza de como qualificar o trabalho. Essa mesma certeza é posta no parágrafo conclusivo, quando o escrevente retoma o mesmo adjetivo, "enraizado". O tom de certeza é também reforçado com o pressuposto que o advérbio já introduz e 
contraria: o de que as invenções, sendo recentes, não são enraízadas. Ao contrariar esse pressuposto, afirmando que o trabalho, sendo uma invenção humana, está enraizada, comenta e reforça, em tom de certeza, a adjetivação:

[10]:

5 § Apesar do termo ter sido uma invenção humana o trabalho já está enraizado no nosso tempo, ocupando o tempo do dia-a-dia [...], ficando evidente sua importância contemporânea e a impossibilidade de se viver sem ele [...] (R171, grifos meus).

Para finalizar o PDV que vinha sendo construído, o escrevente formaliza a importância do trabalho com uma adjetivação epistêmica de certeza, "ficando evidente", para concluir que é impossível se viver sem o trabalho, constituindo, assim, um PDVD no texto.

Pode-se perceber também que, na construção desse PDVD, o escrevente se apoia numa determinada temporalidade para elaborar a qualificação do trabalho:

[11]:

$1^{\circ} \S$ Trabalho, hoje em dia, é um conceito que, cada vez mais, parece enraizado na nossa sociedade, quem não o possuí está fora do sistema [...].

5 $\S$ Apesar do termo ter sido uma invenção humana o trabalho já está enraizado no nosso tempo [...], ficando evidente sua importância contemporânea e a impossibilidade de se viver sem ele (R171, grifos meus).

Essa temporalidade, a da presentificação, é também construída por meio da qualificação. Não se trata de qualquer sociedade, mas da "nossa sociedade", nem de qualquer tempo, mas do "nosso tempo". Ou seja, o escrevente assume o posicionamento de que o trabalho está incorporado em sua vida. Trata-se da sua experiência do trabalho e, exatamente por isso, julga ser impossível viver, hoje, sem ele. A presentificação é ainda mais marcada, quando a enunciação é projetada no enunciado, como se pode notar, a seguir, num trecho do terceiro parágrafo:

[12]:

3 § Outro fator que mostra esse enraizamento é o treinamento a que somos submetidos, desde crianças, para seguirmos alguma profissão, aprendendo matérias que serão uteis para [...], como exemplo passar no vestibular [...] (R171, grifos meus). 
Como se vê, no exemplo [12], o escrevente insere-se no enunciado, projetando a enunciação, ao utilizar-se do nós inclusivo e ao referir-se ao exame vestibular. Tem-se, nesse trecho da redação, a marca explícita da subjetividade que permeia igualmente a redação como um todo nas adjetivações.

\subsection{A ordem dos textos da coletânea e a escolha do segundo fragmento como o privilegiado}

No que se refere ao privilégio ao segundo fragmento como base dialógica para estabelecimento do PDV dominante, não foram encontradas muitas ocorrências. A coincidência maior se dá não na sua escolha, mas no próprio tratamento dado a ele quando é escolhido. Esse tratamento caracteriza-se, de modo geral, pelo conteúdo temático relacionado à desigualdade social, isto é, a questão sócio-econômica do trabalho posta, no fragmento, pelas oposições emprego/desemprego e morte por trabalho em excesso/morte por falta de trabalho.

O diálogo com esse conteúdo temático é bastante recorrente na totalidade do corpus, talvez pelo fato de ser tratado com muita frequência no dia a dia das pessoas, nas mídias, nos debates de modo geral e, exatamente por isso, fazer parte da experiência do escrevente. Nesse modo de abordagem do segundo fragmento, encontramos dois tipos: um, em que predomina a referência ao segundo fragmento, mas na conclusão privilegia-se o primeiro, ou terceiro fragmento (como se verá mais adiante, no próximo item). Outro, em que se privilegia o segundo fragmento no todo da redação, sem referir-se explicitamente ao primeiro ou ao terceiro fragmento.

No exemplo [13], o modo de ler e interpretar os textos da coletânea aponta para uma enunciação das redações como réplica aos fragmentos, mantendo, ainda, a mesma ordem de apresentação desses fragmentos como estrutura da redação:

[13]:

Essencial x Essência

$1^{\circ} \S$ Vital no sentido mais amplo da palavra é que se define o significado do trabalho [...].

2 $\$$ Vital [...], é através do trabalho que o homem conquista o pão de cada dia [...].

3 § No entanto, muito além das necessidades biológicas o homem necessita trabalhar para conquistar seus objetivos, realizar seus sonhos e afirmar sua identidade. Vê-se com mais 
facilidade este último aspecto nos artistas que como Michelangelo põe o sentido que a vida Ihe tras numa obra, [...]. 4 § Todavia, [...], trabalhar pode assumir outro significado, mais negativo, como acontece nos dias de hoje, o trabalho passa ser um martírio, [...]. Então trabalhar perde seu sentido filosófico [...] uma vez que vivemos na época em que a humanidade [...] em uma parte está se "matando" de tanto trabalhar enquanto a outra parte está morrendo por falta de emprego (R174, grifos meus).

Como se nota, no exemplo [13], o primeiro parágrafo dialoga com o primeiro fragmento, fazendo uso do recurso da definição de trabalho. O segundo parágrafo dialoga com o segundo fragmento, com o mote da sobrevivência e, no terceiro parágrafo, tem-se o diálogo com o terceiro fragmento, que trata do trabalho e do trabalho de arte como aquele que dá sentido à vida. Ao final, no parágrafo conclusivo, privilegia-se o segundo fragmento, finalizando com uma citação direta da coletânea, sem, entretanto, marcá-la como tal.

O diálogo com o primeiro fragmento se dá pelo tom conceitual, numa metarreferenciação ao significado da palavra trabalho. Essa definição se realiza por meio da adjetivação avaliativa, "vital". A entrada em cena desse enunciador que abre a redação com a anteposição do adjetivo provoca um efeito de ênfase no posicionamento que o escrevente irá constituir com o desenvolvimento da redação. Esse posicionamento é fortalecido ainda mais, porque a mesma adjetivação também abre o segundo parágrafo, agora não mais para destacar o significado da palavra trabalho, mas por causa da sua importância para o sustento do homem. A repetição da adjetivação reitera um PDV, mas não se constitui como dominante, como observaremos no parágrafo conclusivo.

No terceiro parágrafo, a qualificação do trabalho se amplia, porque não basta ser vital para a sobrevivência, deve servir também "para conquistar seus objetivos, realizar seus sonhos e afirmar sua identidade", como acontece com o trabalho de arte, em que esse aspecto é visto "com mais facilidade". Esse posicionamento é enfatizado com o uso de verbos portadores de valores: "conquistar", "realizar", "afirmar". A direção argumentativa que está sendo construída, rumo a uma valorização positiva do trabalho, é quebrada, quando outro enunciador entra em cena, por meio da conjunção adversativa "Todavia", que abre o quarto parágrafo e direciona a argumentação para a desvalorização do trabalho, qualificando-o como 
"mais negativo", isto é, "um martírio". Vê-se que esse posicionamento, por meio da adjetivação axiológica fortalecida com o intensificador "mais" e do uso do substantivo carregado também axiologicamente com uma carga negativa, "martírio", vai de encontro ao posicionamento anterior. O escrevente solidariza-se com o PDV do segundo fragmento, e reforça esse posicionamento ao por em cena o enunciador desse mesmo fragmento, por meio do discurso relatado: "uma parte [da humanidade] está se 'matando' de tanto trabalhar enquanto a outra parte está morrendo por falta de emprego". Ao introduzir esse enunciador, sem fazer uso de marcas do discurso do outro, o escrevente assume a responsabilidade desse dizer, firmando esse mesmo PDV.

Esse mesmo posicionamento é também assumido em outras redações, em que o diálogo entre escrevente e fragmento da coletânea ocorre apenas com um dos fragmentos, o segundo. Trata-se de um discurso que circula na sociedade, de modo geral, porque se vivencia essa axiologização negativa do trabalho. Essa experiência do trabalho como martírio manifesta um discurso em que se denuncia a desigualdade social e as mazelas do capitalismo, e não vê saída, não se visualiza uma solução. Até se deseja a igualdade, o fim do trabalho escravo, mas, "nas condições do mundo atual”, não há perspectivas de mudança. O PDV que prevalece é o de que o trabalho é exploração, é sofrimento e, não tendo como lutar contra isso, o escrevente solidariza-se com o PDV do segundo fragmento, assumindo-o para si.

Esse PDV pode ser depreendido da redação (R185), cujo diálogo estabelecido com a coletânea se dá diretamente com o segundo fragmento e de maneira bastante incisiva, principalmente nos primeiros parágrafos da redação. Isso é bem visível no quadro (3):

\section{Quadro 3: comparação entre o segundo fragmento e uma redação}

(continua)

\begin{tabular}{||c|l|l|l||}
\hline \multicolumn{2}{||}{ Segundo Fragmento } & \multicolumn{2}{c|}{ Redação (R185) } \\
\hline $1^{\text {a }}$ parte & $\begin{array}{l}\text { Há algumas décadas, pensava-se } \\
\text { que o progresso técnico e o } \\
\text { aumento da capacidade de } \\
\text { produção permitiriam que o trabalho } \\
\text { ficasse razoavelmente fora de moda } \\
\text { e a humanidade tivesse mais tempo } \\
\text { para si mesma. }\end{array}$ & $1^{\circ} \S$ & $\begin{array}{l}\text { Há algum tempo, pensava-se que a } \\
\text { tecnologia e o aumento da } \\
\text { capacidade de produção } \\
\text { permitiriam que o trabalho ficasse } \\
\text { razoavelmente fora de moda e a } \\
\text { humanidade tivesse mais tempo } \\
\text { para si mesma. }\end{array}$ \\
\hline $2^{\text {a }}$ parte & Na verdade, o que se passa hoje & $2^{\circ} \S$ & $\begin{array}{l}\text { Infelizmente não é isso que } \\
\text { acontece, pelo contrário, }\end{array}$ \\
\hline \hline
\end{tabular}


(conclusão)

\begin{tabular}{|c|c|c|c|}
\hline \multicolumn{2}{|r|}{ Segundo Fragmento } & \multicolumn{2}{|r|}{ Redação (R185) } \\
\hline \multirow{4}{*}{$3^{\mathrm{a}}$ parte } & \multirow{3}{*}{$\begin{array}{l}\text { é que uma parte da humanidade } \\
\text { está se matando de tanto trabalhar, } \\
\text { enquanto a outra parte está } \\
\text { morrendo por falta de emprego. }\end{array}$} & $2^{\circ} \S$ & $\begin{array}{l}\text { a disputa por emprego nunca foi } \\
\text { tão acirrada. }\end{array}$ \\
\hline & & $3^{\circ} \S$ & $\begin{array}{l}\text { Em consequência do sistema } \\
\text { econômico vigente, o capitalismo, } \\
\text { tudo custa dinheiro por isso ficar } \\
\text { sem emprego não é um luxo que } \\
\text { muitos possam se dar. }\end{array}$ \\
\hline & & $4^{\circ} \S$ & $\begin{array}{l}\text { Entretanto a conquista de um } \\
\text { emprego por um pessoa em } \\
\text { detrimento de outras dez }\end{array}$ \\
\hline & & $4^{\circ} \S$ & $\begin{array}{l}\text { é um problema que governo } \\
\text { nenhum conseguiu sanar e, em } \\
\text { vista do crescimento populacional é } \\
\text { provável que isso piore. }\end{array}$ \\
\hline
\end{tabular}

Como se pode observar, o PDV do primeiro parágrafo da redação é o mesmo do segundo fragmento. A paráfrase praticamente não se estabelece. O enunciador da redação assume esse dizer como sendo o seu, pois não dá sinais de que se trata do discurso do outro, assume ser ele o responsável por esse dizer. No segundo parágrafo da redação, entra em cena um enunciador que introduz o mesmo PDV do fragmento, modalizado pelo advérbio "infelizmente" e pela negação "não é isso que acontece". Nos parágrafos seguintes, por meio de paráfrase, são introduzidos enunciadores que encenam o mesmo PDV do fragmento e fortalecem esse mesmo PDV, por meio tanto da modalização quanto da adjetivação, resultando numa direção argumentativa mais contundente do que aquela estabelecida no segundo fragmento. Se se observar o exemplo [14], notar-se-á o papel da adjetivação na reafirmação do papel da coletânea:

[14]:

1ㅇ Há algum tempo, [...].

Desemprego

2 § Infelizmente não é isso que acontece, pelo contrário, a disputa por emprego nunca foi tão acirrada.

3으 Em consequência do [...] capitalismo, [...] por isso ficar sem emprego não é um luxo que muitos possam se dar.

4 $§[. .$.$] um emprego por um pessoa em detrimento de outras$ dez é um problema que governo nenhum conseguiu sanar e, [...] é provável que isso piore (R185, grifos meus). 
No segundo parágrafo, o enunciador fortalece um PDV do segundo fragmento, quando modaliza seu texto com o advérbio "nunca", estabelecendo que a "disputa por emprego" piorou, o que pode ser confirmado na adjetivação dessa disputa em "nunca foi tão acirrada" e na ênfase que é dada a essa adjetivação com o intensificador "tão". No terceiro parágrafo, encena um enunciador que introduz um PDV que não se encontra no segundo fragmento, mas fortalece a argumentação na direção do PDVD, que também é construído por meio de uma negação e da adjetivação presente na formulação negação +verbo ser + sintagma nominal: "não é um luxo", acrescida da relativa "que muitos possam se dar".

O escrevente finaliza seu texto, por meio de uma adjetivação em que põe em cena um enunciador que não se manifesta no segundo fragmento, mas que é culpabilizado por essa situação: o governo. Nessa direção, o PDV assumido pelo escrevente aponta para alguém culpado pela situação e que não consegue resolvêla e, exatamente por isso, essa situação poderá piorar. O tom de denúncia é atenuado com a adjetivação epistêmica "é provável”, cujo valor semântico expressa uma probabilidade e não a certeza do que vai acontecer.

As retomadas discursivas da coletânea, especificamente do segundo fragmento, nos exemplos [13] e [14], contribuíram para a construção de um PDV que quer se fazer dominante, com tom de denúncia, mas que se vê vencido pelo sistema capitalista, que defende a exploração.

Na contramão desses pontos de vista, exemplos [13] e [14], que desvalorizam o trabalho com o discurso da permanência da exploração, há também redações, mas poucas, em que o trabalho é exaltado em virtude de sua importância para a sobrevivência, como no exemplo [15]. A construção do PDV se dá ainda pelo diálogo com o segundo fragmento, mas o posicionamento é contrário a ele, pois valoriza o trabalho de modo geral, apesar de referir-se ao problema do desemprego gerado pelo avanço científico:

[15]

O trabalho desenvolvendo a sociedade

1 $§[\ldots]$ o trabalho esteve presente em grande parte da história da humanidade e é, em alguns aspectos, responsável por muitas das caracteristicas presentes no dia-a-dia do homem contemporâneo.

2 $\S[\ldots]$, a busca pela sobrevivência [...]. A criação do dinheiro como recompensa pela realização deste - ideal capitalista - 
também é parte importante da história [...].

3 § O desenvolvimento científico e tecnológico, em conjunto com o crescimento populacional [...] diminuiu o número de empregos disponíveis no mercado, gerando, dessa forma, o maior problema da sociedade capitalista, o desemprego.

4 $\S[\ldots]$ busca por resultados provenientes do trabalho e é principalmente através dele que as pessoas se destacam e crescem. $O$ trabalho tornou-se [...] um processo pelo qual o ser recebe o indispensável para a sobrevivência (R133, grifos meus).

A força da adjetivação, nesse exemplo, é um pouco sutil, pelo uso de adjetivações cristalizadas, como "grande parte", "homem contemporâneo", "ideal capitalista". Destoando dos demais exemplos, neste, o escrevente delimita seu campo de atuação, dialogando mais com o segundo fragmento. No primeiro parágrafo, há a referência à existência do trabalho e a sua relação com os problemas atuais. No segundo parágrafo, há retomadas do segundo fragmento, mas para valorizar aspectos do capitalismo. Já no terceiro parágrafo, é introduzido o mesmo enunciador da coletânea, posto em cena pela afirmação de que o desenvolvimento tecnológico causou o desemprego, "o maior problema do capitalismo". Mas no parágrafo seguinte, o conclusivo, é introduzido um PDV que não compartilha com o PDV posto no terceiro parágrafo, valorizando o trabalho, de modo geral, porque ele propicia o crescimento das pessoas como também seu sustento.

\subsection{A ordem dos textos da coletânea e a escolha do terceiro fragmento como o privilegiado}

No diálogo do escrevente com os textos da coletânea, sendo o terceiro fragmento o privilegiado, também prevalece a manutenção da ordem dos textos da coletânea; porém, há redações em que o escrevente não se prende à ordem dos textos da coletânea, mas privilegia o terceiro fragmento. Assim, o privilégio dado ao terceiro fragmento é, em sua maioria, no parágrafo conclusivo, mas não só nele.

Há textos em que estão presentes diferentes tons avaliativos da qualificação do trabalho, os quais revelam os posicionamentos assumidos pelo escrevente, revelando também o grau de adjetivação que perfaz um julgamento do percurso 
histórico do trabalho. Mantendo o diálogo com a mesma ordem dos fragmentos da coletânea, no exemplo [16], o escrevente trata, no primeiro e segundo parágrafos da definição de trabalho, afirmando que o conceito dele é discutível.

[16]:

1 $§$ Sendo o trabalho, toda e qualquer tipo de atividade humana, o homem sempre trabalhou. Até mesmo no inicio de sua existência. [...], atualmente o conceito de trabalho é discutível.

2 § Hoje, grande parte das pessoas remetem o conceito de trabalho ao dinheiro [...]. $\mathrm{O}$ que não é verdade. 0 trabalho é sim 0 instinto natural do homem em produzir, modificar e criar. É por meio dele que a sociedade se desenvolve. [...] (R221, grifos meus).

Ainda no segundo parágrafo, introduz o diálogo com o segundo fragmento, contextualizando o conceito de trabalho no âmbito capitalista, por meio de um enunciador genérico, "grande parte das pessoas remetem", intensificando esse posicionamento com uma adjetivação dimensional, para conceituar trabalho como dinheiro. Após a intensificação desse posicionamento, o escrevente introduz, pela negação, outro enunciador para contrapor a esse posicionamento: "O que não é verdade" e direciona a argumentação para outro PDV, afirmando categoricamente, na sequência, o que é verdadeiramente o trabalho: "O trabalho é sim o instinto natural do homem em produzir, modificar e criar". Desse modo, ele já aponta para qual direção será conduzido o PDV que está construindo. No parágrafo seguinte, gerenciando uma definição de trabalho que se contrapõe ao PDV do segundo fragmento, o escrevente aponta para o que quer defender:

[17]:

3 $\S[\ldots]$ A pobreza cresce e o trabalho vem se transformando em algo horrível. [...]. De maneira mais extrema, o trabalho deixa de ser prazeiroso e vira perda de tempo (R221).

Utiliza-se, para isso, de uma adjetivação axiológica, que qualifica o trabalho negativamente, "algo terrível". Na sequência, por meio de uma adjetivação avaliativa e intensificada com o "mais", "De maneira mais extrema", firma ainda mais o PDV que está construindo: "o trabalho deixa de ser prazeiroso".

Nos dois últimos parágrafos, quarto e quinto, o escrevente dialoga com terceiro fragmento e com outros discursos, como a Constituição, com os Direitos 
Humanos, com o ideal iluminista. No quarto parágrafo, denuncia o preconceito sofrido pelo trabalho, com uma adjetivação também axiológica e intensificada e, no final do parágrafo, iguala todos os trabalhos, adjetivando-os como dignos:

[18]:

4 § Muito preconceito é encontrado no trabalho também. Músicos, artistas plásticos, filósofos são muitas vezes desmerecidos e rebaixados. [...]. Médico, música ou pedreiro, todos são dignos e possuem a mesma importância perante a sociedade. (R221).

No último parágrafo, introduz uma adjetivação modalizada, para fortalecer o PDV anunciado no final do parágrafo anterior: "É preciso". Na sequência, contrapõese ao segundo fragmento, para finalizar com o PDV que defende:

[19]:

5o § É preciso expandir os horizontes do conceito de trabalho, valoriza-lo de todas as formas, [...] O prazer do trabalho tem que ser reconquistado. Para isso, quebrar preconceitos e ir de frente as influências capitalistas, que individualiza o ser cada vez mais. O trabalho é a glória do homem, e deve ser de todos para todos, em harmonia e igualdade (R221).

Há, no exemplo [19], uma qualificação positiva do trabalho, afirmando que todos os trabalhos precisam ser como o de arte. Para isso, se utiliza da adjetivação deôntica "é preciso" e, ao final do parágrafo, para concluir a construção do PDVD, se utiliza da adjetivação formada pelo verbo ser + sintagma nominal, "O trabalho é a glória do homem" que, juntamente com os substantivos "harmonia e igualdade", estão carregados de valores positivos.

Nesse modo de construir PDVs, isto é, a partir da escolha de um fragmento privilegiado, encontrei outro modo de hierarquização do trabalho de arte, menos incidente na totalidade do corpus, mas que merece destaque pelo modo contundente de qualificar o trabalho de arte, fugindo à dominância marcante da totalidade do corpus, ou seja, a valorização do trabalho intelectual em detrimento dos demais tipos de trabalho.

O exemplo [20] mostra que a hierarquização do trabalho é construída no estabelecimento do diálogo com a ordem dos fragmentos da coletânea, e principalmente a partir da escolha do terceiro fragmento como o privilegiado. Entretanto, o que o torna singular é o modo de hierarquizar o trabalho de arte: 
[20]:

Tudo em nome do Progresso!

1 § Desde o início dos tempos, o motor da humanidade é o trabalho, [...] apresentou mutações, [...] nessa linha perdeu parte de sua essência.

2o § [...]. Inicialmente, utilizava-se do que era oferecido pela Natureza, mas aos poucos viu que seu progresso não se restringia a apenas isso. [...].

3o § No entanto, deixando sobressairem-se suas características mais impuras, rendeu-se à ganância e ao oportunismo: [...] tornou-se escravo de si próprio, e passou a explorar. [...].

4 § $O$ que antes vinha em nome do progresso, passou a regredir: [...]. A modernidade que outrora era para facilitar a vida, tornou-se a "catraca" de exclusão social. [...]. E o "trabalho" que os poucos detentores de riquezas fazem "em nome da arte", é chamado de precioso!

5o § [...]: de um lado, massas esforçam-se para sobreviver; e de outro, os considerados imprescindíveis para a evolução da espécie esboçam rabiscos e projetos irrelevantes, que são considerados trabalhos de arte. [...] (R147).

Pode-se observar, no exemplo [20], uma adjetivação que qualifica negativamente não só o trabalho, de modo geral, mas muito mais o trabalho de arte. O enunciador expressa um tom irônico presente já ao enunciar o título da redação "Tudo em nome do progresso!" -, mas que se tornará mais evidente no desenvolvimento da redação, por meio de um modo particular de qualificar o trabalho de arte. Esse modo diferenciado de qualificar o trabalho de arte é construído pelas escolhas linguísticas que o escrevente faz ao assinalar, em seu texto, elementos qualificadores articulados com o uso de uma pontuação singular aspas e exclamação.

O escrevente marca seu texto do modo como julga mais pertinente para o efeito de sentido que deseja imprimir em sua redação. Utiliza-se, por exemplo, de um tom irônico para marcar a desvalorização o trabalho de arte. Ele assume, no exemplo [20], um posicionamento não muito frequente na totalidade do corpus, mas que chama a atenção do leitor pelo modo como constrói a qualificação do trabalho de arte: por meio da ironia. A adjetivação, articulada com o uso da pontuação, funciona como estratégia discursiva para destacar o posicionamento do escrevente em relação ao trabalho de arte e, ao mesmo tempo, desvelar a imagem que ele quer 
mostrar de si para seu leitor: a imagem de um escrevente que sabe posicionar-se diante de determinado tema e de modo bem marcado.

A qualificação com matiz negativo e tão incisivo em relação ao trabalho de arte mostra, como se vê no exemplo [20], pela pouca ocorrência na totalidade do corpus, tratar-se de um posicionamento diferenciado, no sentido de não ser frequente no senso comum. Esse modo de qualificar o trabalho de arte faz parte da estratégia argumentativa do escrevente, para tentar provar que sabe tomar um posicionamento e construir PDVs, no caso, um posicionamento discordante em relação àqueles fornecidos na prova de redação e que marca uma espécie de ressentimento que associa arte e condição social favorecida, questionando valores já cristalizados na sociedade, como a valorização da cultura por meio da valorização da arte, mas, ao mesmo tempo, assumindo outros, também cristalizados, que identificam arte e riqueza.

A adjetivação, no exemplo [20], mostra mais uma vez que ela é uma estratégia argumentativa, um recurso para construir PDVs que acontece na articulação da adjetivação com a modalização proporcionada pelo uso da pontuação (aspas e exclamação), cuja função é a de fortalecer o tom irônico com que o escrevente qualifica, depreciando o trabalho de arte, como se pode notar no destaque do exemplo [21]:

[21]:

E o "trabalho" que os poucos detentores de riquezas fazem "em nome da arte", é chamado de precioso! (R147, grifos meus).

Pode-se, pois, observar, no exemplo [21], que o escrevente exprime não só seu posicionamento, mas também seu sentimento de rancor em relação ao trabalho de arte. O PDV, neste caso, é textualizado na articulação entre a adjetivação e os sinais de pontuação - aspas e ponto de exclamação -, ambos marcando a modalização, em que o escrevente traz para o texto discursos que circulam em diferentes esferas, mas que, unidos por um ponto comum, a depreciação do trabalho de arte, evidenciam uma postura enunciativa preconceituosa em relação a este tipo de trabalho. Ao marcar o termo "trabalho" entre aspas, o escrevente qualifica o trabalho de arte como um não-trabalho e introduz, no enunciado, um discurso outro construído com o recurso da ironia que, segundo Brait, 
é surpreendida como procedimento intertextual, interdiscursivo, sendo considerada, portanto, como um processo de metarreferenciação, de estruturação do fragmentário e que, como organização de recursos significantes, pode provocar efeitos de sentido como a dessacralização do discurso oficial ou o desmascaramento de uma pretensa objetividade em discursos tidos como neutros. Em outras palavras, a ironia será considerada como estratégia de linguagem que, participando da constituição do discurso como fato histórico e social, mobiliza diferentes vozes, instaura a polifonia [...] (2008, p. 15, grifos meus).

Há, nesse sentido, uma interdiscursividade entre o discurso da coletânea instaurado pelo locutor do terceiro fragmento e o discurso oposicionista do locutor do exemplo [21], que introduz um enunciador para qualificar pejorativamente o trabalho de arte. Creio que, nesse modo de qualificar e modalizar essa qualificação, o escrevente arrisca uma provocação a seu outro, por meio da depreciação do trabalho de arte. No trecho "é chamado de precioso!", o uso da passiva, somado à adjetivação avaliativa, reforça sua postura contrária diante do trabalho de arte. Vejo, ainda, na primeira parte deste trecho, uma tentativa de distanciamento do escrevente em relação ao que se enuncia, dado pelo uso da passiva "é chamado", resultando no apagamento enunciativo. Entretanto, essa tentativa de distanciamento é quebrada pelo uso de um adjetivo avaliativo "precioso", normalmente carregado de uma apreciação positiva, mas que, nesse exemplo, se axiologiza negativamente, tornando evidente o PDV que o escrevente assume e, ao mesmo tempo, assinalando a subjetividade presente e bastante marcada no texto. Nesse trecho do exemplo [21], a tentativa de objetividade, uma exigência do gênero, é descaracterizada por meio da subjetivação presente no modo como o escrevente adjetivou o trabalho de arte.

A escolha de determinada palavra - escolha lexical - é um recurso linguístico de que o escrevente faz uso diante da necessidade de mostrar-se sujeito crítico. Ao introduzir um adjetivo avaliativo axiológico, carregado de certo valor argumentativo, o escrevente intensifica ainda mais a carga argumentativa de seu texto. Essa adjetivação cria um efeito de sentido que, no exemplo [21], exprime um juízo de valor negativo em relação ao trabalho de arte. Essa avaliação não acontece no uso isolado do adjetivo, mas no todo do enunciado, consignado pela enunciação. $O$ uso das aspas na palavra "trabalho" antecipa essa valoração negativa. 
Nesse modo singular de qualificação do trabalho de arte, fica evidente o trabalho do escrevente com a linguagem. Ele toma para si uma palavra alheia, mas "cheia de ecos de outros enunciados" (BAKHTIN, 2003, p. 294). No caso do exemplo [20], detalhado no exemplo [21], o escrevente, ao qualificar com o uso das aspas o "trabalho", assume as palavras do outro: o trabalho é precioso, mas subverte esse valor, dando voz a um discurso oposto. A adjetivação irônica mostra que o escrevente constrói de si a imagem de um sujeito crítico, que não se submete ao discurso oficial, o da instituição que privilegiou o trabalho de arte, ao citá-lo na coletânea. Ele assume a responsabilidade pelo PDV que enuncia a "dessacralização" o trabalho de arte, por meio da adjetivação valorativa negativa. A adjetivação é, nessa perspectiva, uma estratégia argumentativa e, por meio dela, o escrevente constrói PDVs na correlação com outros PDVs.

Nessa qualificação, pode-se perceber de qual formação discursiva o escrevente enuncia, uma vez que ele constrói uma postura marcada pela tensão ideológica, passível de depreensão por meio de um discurso outro presente em seu texto, linguisticamente marcado pela ironia. Trata-se de uma relação de tensão, constituída por um discurso contrário ao que o escrevente depreendeu do fragmento da coletânea. A adjetivação modalizante mostra um modo de dizer bastante específico do escrevente, que corrobora a heterogeneidade de seu discurso. Nela, o escrevente traz à luz seu posicionamento, marcando, por meio da relação de tensão com uma outra, a sua pertença a determinada formação discursiva.

No discurso presente no exemplo [21], o PDV do escrevente foi construído na oposição ao discurso presente na coletânea. Discursos como esses são encontrados até mesmo na totalidade das redações. Trata-se do discurso que valoriza o trabalho, como mostra o exemplo [22]:

[22]:

[...] O maior problema não reside no ato em questão e sim na maneira de interpretá-lo [o trabalho] e conduzi-lo. O caos em que vivemos hoje é que dita o ritmo e a qualidade de um bem precioso como esse (R051, grifo meu).

No exemplo [22], o escrevente faz uso da adjetivação utilizando-se do mesmo item lexical, o adjetivo "precioso", mas seu discurso pertence a outra formação discursiva, diametralmente oposta a do exemplo [21]. Apesar de cada um desses 
escreventes fazer uso do mesmo adjetivo, o modo de adjetivar difere e contribui para marcar a qual formação discursiva pertence cada um desses discursos e para mostrar de que lugar o escrevente enuncia.

O item lexical escolhido para a adjetivação é o mesmo, mas a referência é diferente: "As mesmas palavras podem estar presentes nos dois [textos], mas, com as mesmas palavras, eles não falam das mesmas coisas" (FIORIN, 2003, p. 33). O adjetivo "precioso" está presente nas duas redações, mas não fala da mesma coisa. O sentido não está na palavra isolada, ele se constrói no discurso, a partir do efeito polifônico propiciado por essa adjetivação.

No exemplo [21], o discurso presente foi incorporado do já-dito, de discursos que julgam qual tipo de trabalho pode ser (ou não) considerado um trabalho digno. Esses discursos trazem consigo um viés preconceituoso em relação ao trabalho de arte, porque o consideram um hobby e classificam o artista como preguiçoso, vagabundo. Trata-se de um discurso que afirma que o artista não é um trabalhador, ou que o seu trabalho não serve para a sobrevivência da humanidade ou de seu executor. Esse modo de qualificar o trabalho de arte é pouco recorrente na totalidade do corpus, com apenas $2 \%$ de ocorrência, fato que pode ser explicado pelo modo como esses escreventes representam o seu interlocutor privilegiado: a própria universidade, suposta como defensora do trabalho de arte.

\subsection{A ordem dos textos da coletânea e a escolha da instrução como a privilegiada}

Há textos que, além de dialogarem com os fragmentos da coletânea, também dialogam com a instrução da prova de redação, que faz referência explícita a cada um dos fragmentos da coletânea. Como mencionei anteriormente, a atenção às Instruções dadas pela prova também pode ser um fator que impõe a ordem dos fragmentos como forma de estruturação da redação.

Apresento, no exemplo [23], a redação (R034), para observação da sua totalidade e visualização de sua organização textual e da metarreferência aos fragmentos da coletânea: 
[23]:

1 § As diferentes interpretações sobre a relação do homem com o trabalho são muito peculiares e podem estar relacionadas ao contexto, [...] em que elas foram escritas.

2 o O primeiro texto revela uma visão histórica do trabalho como algo que foi inventado e que não pertence à essência humana. [...].

3o § Do segundo texto, infere-se uma visão realista e pessimista do trabalho, [...]. No lugar do prazer e mais tempo para si mesmo, o homem tem de fato sido um escravo do trabalho. [...].

$4^{\circ} \S \underline{O}$ terceiro texto [...] apresenta uma visão mais positiva e otimista do trabalho. [...], o texto pressupõe que o trabalho é [...], como um ideal romântico, um sonho a ser realizado, um prazer diário de viver. [...].

5 § A subjetividade, portanto, parece estar presente nos três textos escritos sobre o trabalho [...] (R034, grifos meus).

Ao observar o exemplo [23], nota-se uma estrutura bem marcada de organizadores textuais. Na introdução, é anunciado o que será abordado na redação; no desenvolvimento, organizado em três parágrafos, encontra-se a referência explícita aos fragmentos da coletânea, cujos PDVs são tomados no mesmo tom. No parágrafo conclusivo, organizado textualmente com a conjunção "portanto", há tentativa de síntese do que foi desenvolvido nos parágrafos anteriores.

No primeiro parágrafo, por meio da paráfrase, exemplo [24], construída a partir do diálogo com a instrução da prova, exemplo [25], está em cena um enunciador que introduz o mesmo PDV da instrução, funcionando como recorte para introduzir o tema:

[24]:

[...] As diferentes interpretações sobre a relação do homem com o trabalho são muito peculiares [...] (R034).

[25]:

[...] Os três textos acima apresentam diferentes visões de trabalho [...] (trecho do enunciado da instrução da prova de redação).

Vê-se, nessa comparação, o trabalho de retomada da instrução, parafraseado pelo escrevente, para tentar não somente atender ao solicitado na instrução: "relacione esses três textos", mas também para assumir o mesmo PDV da instrução: a existência de "diferentes visões de trabalho" para, a partir dele, construir, ou tentar 
construir o seu PDV. O escrevente assume esse mesmo PDV, ampliando-o por meio da adjetivação: "diferentes interpretações" e "são muito peculiares". Além da adjetivação, o escrevente amplia a força argumentativa dessa qualificação ao utilizar a anteposição do adjetivo "diferentes" e o intensificador "muito". As peculiaridades anunciadas no primeiro parágrafo são detalhadas nos três parágrafos seguintes.

No exemplo [26], o escrevente tenta dar uma orientação argumentativa a partir do PDV do primeiro fragmento, mas se confunde, misturando o segundo fragmento com o primeiro. Pode-se perceber a retomada discursiva do primeiro fragmento no início e no final do parágrafo, entretanto, no desenvolvimento do parágrafo a argumentação baseia-se no segundo fragmento:

[26]:

2 $§ \bigcirc$ primeiro texto revela uma visão histórica do trabalho como algo que foi inventado e que não pertence à essência humana. [...]. Está implícita uma visão negativa, onde não há prazer no trabalho e sim exploração [...], o trabalho poderá ser transformado e, talvez, desaparecer (R034, grifos meus).

No início do parágrafo, está em cena um enunciador que manifesta o mesmo PDV do primeiro fragmento, repetindo as mesmas adjetivações, "visão histórica", "foi inventado", "não pertence à essência humana", mas parafraseando seus conteúdos proposicionais nas retomadas discursivas. O mesmo acontece ao final do parágrafo, por meio da modalização em "o trabalho poderá ser transformado e, talvez, desaparecer". O escrevente emoldura seu enunciado com o PDV tomado do primeiro fragmento e, ao desenvolver esse parágrafo, retoma outro PDV, o do segundo fragmento, para qualificar o trabalho, mas refuta-o, não assumindo como o seu. Ele se distancia do posicionamento ao por em cena um segundo enunciador, "está implícita uma visão [...]", mas, ao mesmo tempo, pela adjetivação avaliativa dessa visão, "visão negativa", ele se marca no texto, assumindo o PDV depreendido do segundo fragmento: "não há prazer no trabalho e sim exploração". Pode-se depreender, desse segundo parágrafo, que o escrevente não constrói seu PDV, ele se solidariza com o PDV da coletânea.

No terceiro parágrafo, ao referir-se ao segundo fragmento, o escrevente avalia o PDV dali depreendido, com uma adjetivação avaliativa e axiológica: "Do segundo texto, infere-se uma visão realista e pessimista do trabalho". Na sequência, o mesmo enunciador, o do segundo fragmento, é mantido em cena e o 
PDV da coletânea é assumido pelo escrevente, novamente pela retomada discursiva desse fragmento, como se pode notar no exemplo [27]:

[27]:

3 § Do segundo texto [...] uma desilusão em relação ao progresso e à tecnologia. No lugar do prazer e mais tempo para si mesmo, o homem tem de fato sido um escravo do trabalho. Para sobreviver, alguns trabalham longas jornadas, outros nem sequer têm trabalho para garantir suas condições de vida mínimas [...] (R034, grifos meus).

$\mathrm{Na}$ finalização do terceiro parágrafo, o escrevente, como no início do parágrafo, numa metarreferância à coletânea, qualifica o trabalho como inserido na "visão contemporânea", reafirmando o PDV da instrução da prova e do segundo fragmento da coletânea. Observemos os três trechos:

[28]:

3 § [...] Este texto está inserido na visão contemporânea das relações do homem com o trabalho (R034, grifos meus). [29]:

[...] o que se passa hoje, [...] (trecho do segundo fragmento da coletânea, grifo meu).

[30]:

[...] O segundo [texto] trata de suas condições no mundo contemporâneo (trecho da instrução da prova de redação, grifos meus).

O enunciador, ao introduzir o mesmo PDV depreendido da coletânea e da instrução da prova, reafirma e fortalece esse PDV por meio das adjetivações presentes ainda no terceiro parágrafo, nos trechos: "alguns trabalham longas jornadas" e "outros nem sequer têm trabalho para garantir condições de vida mínimas". A força argumentativa das adjetivações é estabelecida pela anteposição do adjetivo "longas" e pelo adjetivo dimensional "mínimas".

No quarto parágrafo, o escrevente mantém a mesma estrutura dos parágrafos anteriores, fazendo uma metarreferência ao terceiro fragmento logo no início da redação, além de fazer outras referências semelhantes no decorrer do parágrafo:

[31]:

$4^{\circ} \S \underline{O}$ terceiro texto [...] apresenta uma visão mais positiva e otimista do trabalho. [texto] Adaptado de recente tecnologia 
da internet e falando de um artista da Renascença [...], o texto pressupõe que o trabalho é parte da essência atemporal do homem, [...](R034, grifos meus).

Nesse modo de enunciar, o escrevente aponta para um distanciamento do que se enuncia, não se assumindo como fonte do que se está enunciando, mas, ao fazer uso da adjetivação: "visão mais positiva e otimista do trabalho", molda o PDV posto nesse quarto parágrafo, subentendendo uma valorização do trabalho de arte. O uso do intensificador "mais" e da adjetivação avaliativa e axiológica corroboram o PDV assumido pelo escrevente. Ainda nesse quarto parágrafo, o escrevente põe em cena outro enunciador que se contradiz ao PDV já posto no segundo parágrafo (e tomado do primeiro fragmento), como se pode comparar nos exemplos a seguir:

[32]:

[...] trabalho como algo que foi inventado e que não pertence à essência humana" (trecho do segundo parágrafo de R034).

[33]:

[...] o trabalho é parte da essência atemporal do homem". (trecho do quarto parágrafo de R034).

[34]:

[...] o trabalho não é uma essência atemporal do homem [...] (trecho do primeiro fragmento da coletânea)

Apesar de o escrevente deslizar do seu dizer e se contradizer na manifestação desses PDVs tomados da coletânea, na finalização do quarto parágrafo, ele aponta para a constituição de um PDVD, porque valoriza o trabalho de arte. Esse PDV é introduzido na comparação do trabalho enquanto "essência atemporal do homem" com "um ideal romântico, um sonho a ser realizado, um prazer diário de viver". Neste caso, não é só a adjetivação que contribui para isso, mas também a retomada de uma qualificação, dada pelo uso de substantivos carregados de valores positivos: "ideal", "sonho" e "prazer", que remetem à valorização do trabalho de arte.

No último parágrafo, o escrevente abre mão de uma determinada conclusão, ao finalizar numa direção totalmente diferente do que vinha conduzindo, uma vez que foge à expectativa que a direção argumentativa projetava, como se pode observar no exemplo [35]: 
[35]:

$5^{\circ}$ § A subjetividade, portanto, parece estar presente nos três textos escritos sobre o trabalho. Como um prisma, seus autores filtram informações, palavras, idéias e abordam um mesmo assunto, [...] (R034, grifo meu).

Embora o escrevente faça uso de uma conclusiva "portanto", há uma tentativa de síntese, nesse último parágrafo, que não ocorre. Além disso, não há um PDV definido, pelo menos no que se refere ao objeto de discurso, o trabalho. Há, apenas, comentários sobre os fragmentos da coletânea que se tornam aleatórios a não ser pela tentativa de impressionar seu interlocutor ao selecionar algumas palavras, como "subjetividade" e "prisma". Pelo modo como esse parágrafo foi construído, pressupõe-se uma representação do gênero redação de vestibular tida como modelo, por sua própria constituição esquemática. No parágrafo introdutório, o escrevente anuncia que há "diferentes interpretações" sobre o trabalho. $\mathrm{Na}$ sequência, desenvolve essas diferenças, organizadas cada uma em um parágrafo, elaborando, para isso, mais três parágrafos, cada qual iniciado por um organizador textual: "O primeiro texto", "Do segundo texto", "O terceiro texto". Ao final, no parágrafo conclusivo, utiliza-se da conjunção conclusiva "portanto" e retoma a tese lançada no parágrafo introdutório, como pode ser comparado nos dois exemplos, a seguir:

[36]:

As diferentes interpretações sobre a relação do homem com o trabalho são muito peculiares e podem estar relacionadas ao contexto, $[\ldots]$ em que elas foram escritas. (trecho do parágrafo introdutório de R034, grifos meus).

[37]:

A subjetividade, portanto, parece estar presente nos três textos escritos sobre o trabalho. [...], focando em aspectos que thes parecem pertinentes conforme o contexto em que estão escrevendo (trecho do parágrafo conclusivo de R034, grifos meus).

No que se refere à redação (R034) em sua totalidade, o escrevente apropriase dos PDVs que ele depreende da coletânea e, por meio da adjetivação, reafirmaos. A força argumentativa dessa adjetivação é complementada com a descrição do que é o trabalho: "o trabalho é parte da essência atemporal do homem, como um 
ideal romântico, um sonho a ser realizado, um prazer diário de viver". A valorização positiva do trabalho de arte é dada pelo julgamento do escrevente, que o leva a posicionar-se contrário ao PDV posto no primeiro fragmento, "O trabalho não é uma essência atemporal do homem". Nesse jogo de posicionamentos, o escrevente coloca-se em uma posição oposta, no que se refere à definição de trabalho descrita no primeiro fragmento. Ele parte dessa oposição para assumir um posicionamento em que o trabalho de arte é apreciado positivamente.

Da análise da construção do PDVD e relação dos textos dos vestibulandos com a coletânea e com as Instruções, depreende-se que a construção do PDVD e o modo de qualificar o trabalho e o trabalho de arte são resultados não só do seu modo de ler os textos fornecidos pela prova de redação como também de suas representações, tema a que me dedico no próximo capítulo. 


\section{CAPÍTULO 4}

\section{CONSTRUÇÃO DO PDVD E REPRESENTAÇÕES SOCIAIS}

Neste capítulo, analiso a construção do PDVD e busco, a partir dela, as representações sociais do escrevente sobre o trabalho, sobre a Universidade e sobre os saberes provenientes de outras esferas. No primeiro item (4.1), trato das representações sociais do trabalho depreendidas do diálogo do escrevente com os textos da coletânea. No item (4.2), ocupo-me da representação social do escrevente sobre a Universidade em sua relação com o que ele imagina ser a representação social do trabalho e do trabalho de arte para a Universidade. No último item, (4.3), abordo a construção do PDVD a partir das representações do escrevente sobre os saberes mobilizados de esferas sociais diferentes da que dispõe imediatamente para fazer a prova - a coletânea.

\subsection{A construção do PDVD e a representação social do trabalho}

O tema "o trabalho" oferecido pela prova é muito amplo. Segundo Fígaro (2008, p. 93), em estudo dos discursos que circulam nas empresas sobre as relações de trabalho, essa amplitude deve-se ao fato de o trabalho ser uma categoria "difusa e complexa, característica de fundamento da sociedade, pois lugar privilegiado que abriga grande parte da atividade humana". Nesse sentido, esse campo de referências pode abranger diferentes categorias: as que considero presumíveis, tais como, aquelas relacionadas diretamente com os textos da coletânea e da instrução; mas também outras, talvez menos prováveis: "conceitos como trabalho, relações de trabalho, vínculo empregatício, mercado de trabalho, salário, tecnologia, troca, lucro, capital, organizações, controle, poder, sociabilidades, cultura, relações de comunicação" (FÍGARO, 2008, p. 93), e, ainda, outras que fogem totalmente a um controle ou uma delimitação. Desse modo, o escrevente se defronta com um leque muito amplo de possíveis abordagens do tema "o trabalho". A abordagem do trabalho nas redações, de um lado, aproxima-se mais da coletânea e, de outro, afasta-se dela, abrangendo variadas esferas sociais. Cada 
fragmento da coletânea estimula determinado campo semântico, que traz consigo representações sociais do trabalho, segundo a visão do escrevente.

Numa discussão sobre "o trabalho" circulam diferentes discursos com seus respectivos valores, crenças e ideologias. Há, nas redações, dois eixos de circulação desses discursos: um, em que se valoriza o trabalho; outro, que 0 deprecia. Há, também, o discurso que representa o PDV do trabalhador (os direitos do cidadão trabalhador) e o do patrão (a defesa do capital).

As representações sociais do trabalho são fortemente determinadas pelas condições de produção do discurso do escrevente. Além disso, é marcante também a experiência do trabalho para o escrevente, vivida in loco, pelo escrevente trabalhador e/ou depreendida dos discursos sobre o trabalho que circulam na sociedade, como também de seus letramentos, isto é, a experiência do trabalho vista pelo escrevente pelo viés do outro/Outro. Segundo o dicionário Houaiss (HOUAISS; VILLAR, 2002), representação é a "idéia ou imagem que concebemos do mundo ou de alguma coisa". Na rubrica filosofia, representação é a "operação pela qual a mente tem presente em si mesma a imagem, a ideia ou o conceito que correspondem a um objeto que se encontra fora da consciência" (HOUAISS; VILLAR, 2002). Além disso, "a representação social coloca em relação a visão de um objeto dado com a filiação sociocultural do sujeito" (AMOSSY, 2007, p. 50). O que permite dizer que a construção da representação social do trabalho, pelo escrevente, vincula-se à construção da imagem de si, do outro e do Outro, a partir de lugares sociais determinados pelas condições de produção dos discursos sobre $o$ trabalho.

Essas imagens aparecem sob diferentes aspectos nas redações e podem ser depreendidas, por exemplo, a partir das ocorrências de sinonímias de trabalho. Nas redações, é bastante frequente a ocorrência de sinonímias ${ }^{65}$ do termo trabalho, por exemplo, "ofício", "labor", "profissão", vista por Seelaender (2008, p. 4) como sinonímia lexical ou, "uma invenção histórica" ou "todas as atividades que exigem do homem, esforço, dedicação, tempo, concentração, inteligência, sabedoria, competência, administração entre outras coisas", como sinonímia estrutural. Cabe salientar que, na depreensão das representações sociais de trabalho nas redações,

\footnotetext{
${ }^{65}$ SEELAENDER (2008) estudou as ocorrências de sinonímia do termo trabalho em redações de vestibular da FUVEST 2006.
} 
parto de sinonímias nelas encontradas, mas não vistas isoladamente. Pelo contrário, vistas vinculadas à construção do PDVD e à qualificação do trabalho. Destaco, ainda, um dado interessante da pesquisa de Seelaender: segundo a autora, o uso da sinonímia estrutural "permite um deslizamento dentro do campo semântico, [e] pressupõe-se uma maior possibilidade de interferência do campo axiológico do estudante" (SEELAENDER, 2008, p. 13). Nesse sentido, depreender a representação social do trabalho, por meio da qualificação, pode ter resultados significativos, facilitando a vinculação da representação social à construção de PDVs e do PDVD.

Da mesma forma que no item anterior, a análise está organizada na relação entre as redações e os fragmentos da coletânea, agora, não mais observando a estrutura da redação, mas a representação social do trabalho aplicada à coletânea. Exemplifico a construção do PDVD e o modo como o escrevente constrói as representações sociais do trabalho no diálogo com os fragmentos da coletânea.

\section{A. A representação social do trabalho aplicada ao primeiro fragmento}

O primeiro fragmento possui um campo semântico, pode-se dizer, mais filosófico, em que se aborda a origem do trabalho vinculada à sua definição e à possibilidade de sua transformação ou de seu desaparecimento. As representações sociais do trabalho aplicadas ao primeiro fragmento estão delimitadas por esse campo semântico. Entretanto, como dito anteriormente, a representação social é construída pelo escrevente na interação com seu outro, num jogo de posições sociais determinadas pelas condições de produção e, nesse sentido, não há limites para essa construção.

Há três tipos predominantes de representações sociais vinculadas ao primeiro fragmento. Uma, que responde a ele, afirmando que o trabalho não vai acabar, correspondendo a um PDVD. Outra, com um caráter mais conceitual, definindo o que é trabalho. Vale salientar que esse tom conceitual é recorrente em várias redações, mas, no que se refere ao primeiro fragmento, não constitui um PDVD (diferentemente do que ocorre com o segundo fragmento). Outra representação depreendida é a relacionada à origem do trabalho, mas que igualmente não constitui um PDVD. Há, assim, três representações sociais de trabalho mais salientes escolhidas para análise. 
Nos exemplos [38] e [39], os enunciadores afirmam que o trabalho não deve acabar:

[38]:

$4^{\circ}$ § Dificilmente o trabalho deixará de existir pois de uma forma ou de outra estamos sempre praticando-o tanto para o nosso bem profissional ou pessoal, ele ajuda a nos sentirmos completos, mais úteis (R010).

[39]:

5o § A extinção do trabalho seria um acontecimento que traria grande pavor e miséria aos povos (R157).

Verifica-se, nos exemplos acima, que o escrevente afirma e justifica o motivo pelo qual o trabalho não deve acabar. Como réplica ao enunciado do primeiro fragmento, ele responde por meio das modalizações e adjetivações. A qualificação dada ao trabalho é axiologizada com valores eufóricos - "ajuda a nos sentirmos completos, mais úteis" [38] - e quando disfóricos, como em "grande pavor e miséria" [39], é igualmente para fortalecer o posicionamento do escrevente, o de que o trabalho não vai acabar, porque é "parte fundamental do homem". Desse modo, as representações sociais vinculadas ao PDV de que o trabalho não vai acabar são: o trabalho não acaba porque é importante, porque é fundamental para a humanidade, porque ele ajuda a nos sentirmos completos e mais úteis, etc. Essas representações, com mesmo campo semântico, mostram de que lugar o escrevente fala e se posiciona, explicitando sua visão de mundo: trata-se de um PDV que defende o trabalho, valorizando-o e desvelando a ideologia que está por trás dessa apreciação: a conformação com o sistema capitalista.

Em outra ocorrência desse diálogo, exemplo [40], o enunciador afirma que o trabalho deve acabar:

[40]:

5 § Em síntese, o fim do trabalho seria muito bom, pois os seres humanos aproveitariam mais suas vidas e ocupariam seus cérebros em atividades mais saudáveis (R235).

No exemplo [40], está em cena um enunciador que tenta persuadir seu leitor de que o fim do trabalho é um benefício, para que os seres humanos possam aproveitar a vida, ocupando suas mentes com atividades saudáveis. Ao utilizar-se do intensificador mais em "ocupariam seus cérebros com atividades mais 
saudáveis", o enunciador está se opondo à qualificação do trabalho como atividade não saudável. Assim, não sendo boa para os seres humanos, o enunciador sugere o fim dessa atividade. O benefício do fim do trabalho é destacado na adjetivação com intensificador "muito" em "muito bom". Mas, por outro lado, o escrevente levanta uma hipótese, uma possibilidade, apenas, porque não afirma categoricamente esse posicionamento ao fazer uso do futuro do pretérito: "o fim do trabalho seria muito bom". A representação social aqui depreendida é a de que o fim do trabalho seria bom porque ele é uma atividade ruim, não é saudável, mas isso não está concretizado. Apesar de esse desejo não estar concretizado, essa representação denuncia o trabalho como não saudável aos seres humanos.

O recurso da definição é frequente em redações de vestibular, de modo geral. Esse recurso, na totalidade do corpus analisado, é bastante recorrente, principalmente no primeiro parágrafo das redações. Sabe-se que a definição pode funcionar como um recurso para a entrada no tema, mas vejo essa recorrência como réplicas ao enunciado do primeiro fragmento, em que algumas são mais salientes e nem o parafraseiam, como em: "O trabalho é uma invenção histórica” (R150); outras, menos salientes, "é uma 'invenção' do homem" (R165). Outras tentam, ainda, distanciar-se ainda mais, como em "O trabalho é a personificação da história da humanidade" (R216).

O diálogo entre a coletânea e os enunciados das redações evidencia o modo como o escrevente compreende e lê esses enunciados. O diálogo revela que nesse modo de compreensão há uma apropriação de valores, os mesmos do primeiro fragmento. A representação social depreendida desse diálogo é a de que o trabalho é uma invenção histórica e, neste caminho, o escrevente solidariza-se com um PDV da coletânea, assumindo-o para si.

As retomadas da segunda parte do primeiro fragmento: "[...] Ele é uma invenção histórica [...]" foram, de certa maneira, mais frequentes devido, talvez, à sua estrutura ser composta por uma afirmação, o que facilitou a leitura e interpretação do que possa ser histórico e inventado, uma vez que são termos bem conhecidos dos escreventes. Já na primeira parte, ocorre o inverso. $O$ trecho "O trabalho não é uma essência atemporal do homem [...]" tem um caráter mais filosófico, em função dos termos "essência" e "atemporal". Além disso, ele é formado por duas negações "não é uma essência" e "atemporal", dificultando, talvez, a 
compreensão, e aumentando o campo de deslizamento na interpretação. As paráfrases foram menos constantes, a não ser pelo uso do termo "essência", que deslizou para o tratamento dado ao trabalho e, principalmente, ao trabalho de arte.

O tom conceitual constituído pela negação, isto é, dizer o que não é, manteve-se nas paráfrases, ocorrendo apenas a variação verbal:

[41]:

Mesmo não sendo uma essência atemporal do homem. [...] O motivo é essa relação homem trabalho, o bem material sem uso definido, [...] (R042).

No exemplo [41], o enunciado é introduzido sem marcas do discurso do outro. Nesse caso, o escrevente assume o que o enunciador do fragmento enuncia, sem informar que se trata do discurso do outro, tentando distanciar-se do enunciado de origem, apagando as marcas do outro, para assumir o enunciado como seu. Já no exemplo [42], o escrevente põe em cena um enunciador, o mesmo da coletânea, introduzido por meio do discurso relatado, informando fonte e responsabilidade pelo que é enunciado:

[42]:

1 § Segundo A. Simões, "o trabalho não é uma essência atemporal do homem. Ele é uma invenção histórica e, como tal, pode ser transformado e mesmo desaparecer". Trabalhar é uma necessidade gerada de acordo com o momento. (R207, grifos meus).

Nessa mesma redação (R207), a retomada é usada não tanto por seu conteúdo semântico, isto é, pela equivalência de sentido, mas como ponto de partida para o escrevente construir sua argumentação na sequência do texto, ou seja, funcionando como recorte. O escrevente assume o mesmo PDV da coletânea, solidariza-se com ele, mas a representação social do trabalho depreendida não é a que faz referência a essa paráfrase, mas à qualificação do trabalho, constituída na sequência da paráfrase, exemplo [43]:

[43]:

1 § Segundo A. Simões, "o trabalho não é uma essência atemporal do homem. Ele é uma invenção histórica e, como tal, pode ser transformado e mesmo desaparecer". Trabalhar é uma necessidade gerada de acordo com o momento.

2 $\$$ Na pré-história é evidente o sedentarismo do homem. [...]. 
3o $\S$ Durante o decorrer dos anos, as formas de trabalho foram sendo modificadas, visando a uma maior produção em um menor espaço de tempo, o que pôde ser verificado através das Revoluções Industriais [...] (R207).

O escrevente constrói uma representação social do trabalho, ancorada temporalmente e vinculada ao histórico, ou seja, em cada época, o trabalho é visto de um modo. As retomadas, de modo geral, não foram ampliadas como aquelas que trataram da invenção histórica do trabalho. Elas se restringiram ao discurso relatado, para, pelo menos, ficar explícito no texto o solicitado na instrução da prova, isto é, relacionar o desenvolvimento temático com os textos da coletânea.

Ocorrem outras retomadas discursivas desse mesmo trecho do primeiro fragmento, mas de maneiras diferentes. A retomada é posta para contrariar o PDV do enunciado de origem:

[44]:

Ao contrário do que afirma $A$. Simões, o trabalho é, sim, uma "essência atemporal do homem". Observa-se que o serhumano, em seu estado primitivo, já trabalhava: caçava, protegia seus descendentes e a si mesmo. Portanto, o trabalho sempre existiu, mas se desenvolveu no decorrer dos anos de algo necessário à sobrevivência à ferramenta manipuladora (R109).

A representação social do trabalho é, pois, constituída na sequência do texto, isto é, o trabalho sempre existiu e se transformou com o passar dos anos. Há retomadas em que o escrevente toma o termo "essência" isolado de seu texto fonte, para qualificar o trabalho no diálogo com os outros dois fragmentos da coletânea, promovendo, assim, um deslizamento de sua interpretação:

[45]:

Os seres humanos começaram a dedicar-se a construir casas templos, edificações, passaram a pesquisar a natureza e a essência da vida (R024).

Para finalizar esta primeira parte, trato da construção de representações sociais ligadas à origem do trabalho. A representação social do trabalho depreendida é a de que o trabalho sempre existiu, exemplo [46], ou passou a existir junto com o homem, exemplo [47], e, a partir daí, começou a se transformar no que é hoje, servindo principalmente para o sustento: 
[46]:

1ㅇ $\S$ Desde os primórdios da civilização humana, o homem usa sua força física e intelectual para realizar projetos em seu benefício (R079).

[47]:

1 $\S$ Quando o primeiro homem ambicioso e com fome de avanço surgiu, criou-se o trabalho (R214).

De modo geral, as representações sociais depreendidas do diálogo do escrevente com o primeiro fragmento da coletânea giram em torno da definição do que é o trabalho, tendo essa definição um campo semântico delimitado pela origem, pela permanência ou pelo fim do trabalho. No que se refere à definição, a representação social do trabalho predominante é a de que ele é uma invenção histórica. Quanto à origem, a representação social do trabalho é a de que o trabalho sempre existiu ou passou a existir junto com o homem, e, a partir daí, começou a se transformar no que é hoje, servindo principalmente para o sustento. As representações vinculadas ao PDV de que o trabalho não vai acabar são: o trabalho não acaba porque é importante; o trabalho não acaba porque é fundamental para a humanidade; o trabalho não acaba porque ele ajuda a nos sentirmos completos e mais úteis. Há, nessas representações a valorização positiva do trabalho.

\section{B. A representação social do trabalho aplicada ao segundo fragmento}

O campo semântico que compõe o segundo fragmento também abre um vasto leque de possibilidades de abordagens, mas com um núcleo centralizado nos problemas da falta de emprego e no excesso de trabalho que deixa a humanidade sem tempo para si, além de fazer referência ao progresso técnico. Pode-se dizer que o segundo fragmento tem um caráter mais social de abordagem do trabalho. Esse aspecto, depreendido do segundo fragmento, facilitou a discussão dos escreventes, uma vez que são abordagens bastante veiculadas na mídia e também porque o escrevente se apoia na experiência do trabalho. Trabalhando ou não, o escrevente está exposto a essa discussão.

A abordagem pelo caráter social do trabalho é bastante significativa na totalidade do corpus. Inseridas nesse caráter, estão duas formações discursivas, cujos embates são diametralmente opostos e desvelam lugares discursivos bem 
determinados. De um lado, aqueles que atribuem ao trabalho os males da humanidade e, nesse sentido, trabalho é exploração, necessitando se transformar. De outro, os que enaltecem o trabalho e afirmam que, sem ele, não é possível viver. As representações sociais depreendidas a partir do segundo fragmento são bastante variadas na expressão, mas os PDVs vinculados a elas são em menor número. É possível encontrar referências combinadas ao primeiro fragmento da coletânea quando, por exemplo, o escrevente caracteriza o trabalho também pela definição, agora não mais pelo aspecto da sua origem, mas para enfatizar um dado modo de qualificar o trabalho.

Há três tipos predominantes de representações sociais vinculadas ao segundo fragmento. Uma primeira, que se apropria de um PDV da coletânea. Nesse caso o trabalho é qualificado negativamente, com um tom bastante axiológico. Outro, que parte desse mesmo PDV, mas aponta para um caráter mais deôntico, posto pela necessidade de mudança, dada a importância que o trabalho teria para a humanidade. O caráter de denúncia aponta uma qualificação axiológica e a manifestação da necessidade de mudança marca a diferença entre uma representação e outra. Além dessas duas representações, há também aquela que representa uma qualificação positiva do trabalho, em virtude da sua importância para a sobrevivência ou para algum tipo de crescimento favorável ao desenvolvimento humano, seja no plano individual ou coletivo. A qualificação, nessas redações, apresenta um matiz mais conceitual, indicado pela formulação trabalho é, apresentando também um caráter de denúncia.

A representação social construída a partir da solidarização com o PDV do segundo fragmento, que qualifica negativamente o trabalho, é carregada de valores axiológicos, estabelecidos na adjetivação ou na modalização, como se pode observar na sequência de exemplos, a seguir:

[48]:

a força de trabalho é explorada brutalmente, está-se agredindo um dom natural do ser, aproximando-o de uma máquina até transformá-lo nela (R079).

[49]:

o trabalho é visto como uma árdua obrigação pela qual se recebe uma insignificante recompensa (R098).

[50]: 
É lógico que nosso sistema de trabalho atual é extremamente excludente (R194).

[51]:

o trabalho é prejudicial ao homem (R198).

A representação social do trabalho depreendida dessas redações é a de que ele é ruim, gera sofrimento e que há exploração. Essa representação é fortalecida pela qualificação axiológica marcada nas adjetivações axiológicas, como em "árdua obrigação"; "é prejudicial", nas adjetivações modalizadas como em "a força de trabalho é explorada brutalmente", "extremamente excludente"; ou mesmo nas qualificações em que os substantivos são axiologizados por uma carga negativa, como em "é o martírio", exemplo [52].

[52]:

consideram [o trabalho] obrigação diária, o que para algumas pessoas é o martírio, para outras não passa de um dever a cumprir (R153).

Há redações que denunciam a exploração motivada pelo trabalho, mas que não se utilizam da adjetivação para isso, fazem a partir das retomadas discursivas parafraseadas do final do segundo fragmento, como mostram os exemplos [53] e [54]:

[53]:

Alguem disse que o correto é trabalhar para viver. No entanto, o que se passa é que vive-se para trabalhar (R105).

[54]:

Infelizmente as estatísticas revelam que há milhões de pessoas desempregadas, enquanto uns se matam de tanto trabalhar, outros tentam pela falta de trabalho não morrer de fome (R167).

As adjetivações e as modalizações estabelecem as representações sociais do trabalho que estão, de certa maneira, vinculadas a um PDV do segundo fragmento. $\mathrm{Na}$ construção dessas representações, o modo de qualificar apresenta variações, mas tomam sempre o mesmo PDV.

Nos exemplos a seguir, a representação social construída vincula-se a um PDV do segundo fragmento, mas retoma também o aspecto da transformação presente no primeiro fragmento, apresentando caráter mais deôntico de mudança. A justificativa de mudança apresenta-se na qualificação, muitas vezes modalizada, 
valorizando-se ainda mais o trabalho e a importância da sua existência para a humanidade:

[56]:

Não é necessário acabar com o trabalho, mas uma reformulação, onde pessoas não tenham suas vidas condenadas, é bem vinda (R150).

[57]:

A cada dia que passa, mais se complica a vida de quem não tem acesso ao trabalho e ao mesmo tempo, os que o possuem ficam cada vez mais sobrecarregados. O trabalho é algo que nasceu na pré-história e que precisa ser reciclado sempre através dos anos (R210).

Os exemplos mostram uma valorização do trabalho, justificando sua existência, mas com a necessidade de mudança para melhorar a situação atual na qual se encontra o trabalho e os trabalhadores. Desse modo, a representação social do trabalho é a de que ele é gerador de desigualdade, porque explora o trabalhador, mas em razão da sua importância para a humanidade precisa sofrer alterações. $\mathrm{Na}$ construção de representações sociais o escrevente constrói uma imagem de um sujeito politizado, que reconhece as mazelas do capitalismo, que gera a desigualdade social, denunciado-o e, não se contentando com essa situação, busca sua transformação, sua mudança.

Outra representação social do trabalho ressalta a valorização do trabalho em razão da sua importância para o sustento (sobrevivência):

[58]:

o trabalho é de suma importância para a sobrevivência (R099).

[59]:

o trabalho é ainda a forma de sustento e a possibilidade mais certa de ascensão social (R246).

Há outra representação, cujo campo semântico do progresso científico (tratado no segundo fragmento) se mostra como fator positivo na qualificação do trabalho:

[60]:

Definitivamente é necessário que todos trabalhem se quiserem o conforto que a tecnologia apresenta (R018).

[61]: 
O trabalho é o resultado de aprimoramentos técnicos, avanços científicos e acima de tudo, expressão do grau de desenvolvimento humano (R117).

A partir das qualificações presentes nesses exemplos, percebe-se que 0 escrevente constrói uma representação social do trabalho que não denuncia o capitalismo ou o progresso científico como causadores da exploração. Pelo contrário, essas qualificações firmam um posicionamento que valoriza o trabalho, atestando sua importância e necessidade principalmente para a sobrevivência, desvelando a representação social do trabalho que o vê como algo bom e útil para a humanidade, porque, por meio dele, se teria o sustento, possibilitando também outros benefícios, como ascensão social e desenvolvimento e mesmo a igualdade.

De modo geral, as representações sociais do trabalho vinculadas ao segundo fragmento dividem-se em dois eixos, um disfórico, em que há a desvalorização do trabalho: trabalho é ruim, gera sofrimento e exploração; outro, eufórico, que parte da desvalorização do trabalho, mas, devido à representação de que ele é importante para humanidade em si e para o seu sustento, valoriza-o, manifestando a necessidade de sua mudança. Ainda no eixo eufórico, há a representação em que se valoriza o trabalho, em virtude da importância que teria para algum tipo de crescimento favorável ao desenvolvimento humano.

\section{A representação social do trabalho aplicada ao terceiro fragmento}

O terceiro fragmento traz uma especificidade do trabalho, porque apresenta um tipo apenas, o de arte, que é valorizado já pelo enunciador da instrução da prova de redação pela adjetivação "famosa escultura". Esse fragmento traz em seu texto também o aspecto da definição, agora, do trabalho de arte: "o trabalho de arte é um processo. Resulta de uma vida" (trecho do terceiro fragmento). E para fortalecer esse argumento do processo e do resultado, o enunciador finaliza seu texto, apresentando o resultado do trabalho de Michelangelo, a escultura "David". Desse modo, o tom conceitual permanece e é também retomado nas redações, mas agora num movimento comparativo entre os tipos de trabalho, isto é, o trabalho de modo geral e o trabalho de arte, este visto, às vezes, não somente como uma parte de um todo, mas exatamente como um todo quando, por exemplo, faz-se referência ao trabalho que depende da formação acadêmica, o trabalho intelectual. 
A representação social compreendida a partir do diálogo do escrevente com o terceiro fragmento sintetiza, de modo especial, a qualificação do trabalho e do trabalho de arte, uma vez que ela desvela a representação do escrevente sobre a Universidade, tema que será tratado no item (4.2). A presença dos outros dois textos da coletânea também reverberam nesse diálogo com o terceiro fragmento, resultando também em diferentes modos de presença, por exemplo, o tom conceitual, o uso do termo essência ou no modo de contrapor o prazer do trabalho/trabalho de arte ao sofrimento do trabalho de modo geral, como tratado no segundo fragmento. A representação social do trabalho de arte que prevalece é aquela que o relaciona ao prazer, à felicidade, à realização, à notoriedade, beleza, liberdade, estabelecendo um tom eufórico bastante recorrente nas redações. A qualificação, nesse diálogo, aparece de diferentes maneiras, pela própria adjetivação, ou por meio do uso de substantivos ou verbos carregados com esses mesmos valores. Essa representação é percebida na qualificação direta do trabalho de arte, exemplos [62]:

[62]:

Porém, não existe apenas o "trabalho sacrificio", e sim também, o trabalho prazeiroso, como é o caso do trabalho artístico (R226)

A qualificação positiva do trabalho de arte também é projetada para o trabalho de modo geral, em que o escrevente julga necessário que todo trabalho seja como o trabalho de arte, exemplos [63] e [64]:

[63]:

O trabalho deve ser algo que evolua no sentido de ser uma forma de libertar a sua criatividade e valor próprio (R045).

[64]:

Sem negar seus benefícios como capital e posição social o trabalho de todos, operários, advogados,... deveria ser como o dos artistas (R116).

Essa projeção também se mostra presente na necessidade de transformação do trabalho exploração para o trabalho prazer:

[65]:

Portanto, de ocorrer uma mudança no atual sistema econômico e o homem não precise mais vender seu trabalho para sobreviver, sobrará tempo para que se dedique às artes. 
Teremos, então, uma sociedade com as máquinas trabalhando e o homem pensando (R036).

[66]:

A libertação de um trabalho embrutecedor no atual estágio das forças produtivas isso é possível, para que o homem possa desenvolver suas habilidades mais sublimes e todos tenhamos tempo para criar e admirar obras como "David" de Michelangelo (R154).

Há uma representação do trabalho de arte que merece destaque tanto pelo modo contundente de ser em relação às demais, como pela baixa ocorrência na totalidade do corpus. Trata-se da desvalorização do trabalho de arte, tendo como eixo dessa qualificação o sustento, a sobrevivência, como nos exemplos [67] e [68]:

[67]:

Podem ser considerados impressionantes os valores a que o mundo chegou: de um lado, massas esforçam-se para sobreviver; e de outro, os considerados imprescindíveis para a evolução da espécie esboçam rabiscos e projetos irrelevantes, que são considerados trabalhos de arte (R147, grifos meus).

[68]:

Por consequente temos o trabalho artístico e social, no qual quem realiza-o não necessita se manter, ou alguém que não teria condição de realiza-lo provém outra para que o faça.

Nas duas formas o que difere é a razão (necessidade) de o fazer. Ou por simples ocupação do tempo, por já ter sua subsistência garantida, [‥] (R217, grifos meus).

Como se observa, a representação social do trabalho de arte, nos exemplos [67] e [68], revela a ideologia em que se atribui poder de sustento somente aos trabalhos que não são trabalhos de arte, sendo este reservado apenas ao lazer, ao prazer e, neste caso, sendo visto como hobby, traduzindo o artista como vagabundo e sempre sustentado por outro trabalhador não artista.

De modo geral, como visto neste item, no diálogo com o terceiro fragmento prevalece a representação social do trabalho de arte que valoriza esse tipo de trabalho e o coloca como modelo para os demais tipos. Essa representação mostra um jogo de posicionamentos, em que, por um lado, o escrevente constrói imagens de si, mostrando-se como alguém que valoriza a arte, de modo geral; e, por outro, 
imagens de seu interlocutor privilegiado, formadas com base no que a arte poderia representar para ele, na qualidade de corretor e de representante da universidade.

A exemplo do que vimos nos itens $A$ e $B$, pode-se concluir, também para o presente item, e, portanto, para todos os itens que tratam das representações sociais do trabalho no diálogo com os fragmentos da coletânea, que o escrevente, ao construir o PDVD, constrói diferentes representações sociais do trabalho, vinculadas aos PDVs depreendidos da coletânea e direcionadas para a construção do PDVD.

\subsection{A construção do PDVD e a representação do escrevente sobre a universidade}

Tendo em vista a presença marcante de um modo de enunciação do trabalho de arte, como pode ser percebido nas análises anteriores, neste ponto dedico-me a mostrar de que modo a leitura que o candidato faz do terceiro fragmento da coletânea remete a construção do PDVD à representação do escrevente sobre a universidade. Em outras palavras, visa mostrar que a assunção da superioridade do ofício do artista corresponderia ao que o escrevente imagina ser a posição da universidade no tocante à relação entre o trabalho de arte e os demais.

Nesse modo de hierarquizar o PDV, o diálogo com o terceiro fragmento aparece nas redações de várias maneiras. Centralizo a discussão para as remissões, presentes nas redações, que se referem à esfera educacional, abrangendo a educação acadêmica, a formação, os estudos, profissões que exigem formação acadêmica.

Para facilitar a menção aos tipos de trabalho vinculados ao de arte e aos da esfera educacional, utilizo a expressão trabalho intelectual66, na tentativa de abranger a todos eles, e no sentido de se contrapor aos demais tipos trabalhos não compreendidos nessas categorias, considerado, muitas vezes, trabalho braçal.

\footnotetext{
${ }^{66}$ Restrinjo o sentido de intelectual para a acepção de próprio de intelectuais, reunindo, nessa categoria, os artistas de todos os matizes (desde os populares até os da chamada alta cultura) e aquelas pessoas cujos interesses e/ou atividades dirigem-se, a partir da cultura letrada e da escolarização, à cultura em geral, à literatura em geral, às artes, à ciência.
} 
Na maior parte das redações, é predominante a referência à educação formal, vinculada à instituição escolar. O escrevente toma a educação, de modo geral, como a "salvadora da pátria", aquela que pode solucionar todos os problemas da sociedade. A representação social do trabalho intelectual é construída a partir da equivalência entre educação e trabalho, isto é, ter bom estudo resulta em ter bom trabalho, em sucesso, em trabalho-prazer; aquele que não estuda é excluído da sociedade e não é contemplado com um trabalho digno, não é privilegiado.

No exemplo [69], o PDVD é construído com base nessa representação social de trabalho, isto é, a que privilegia o trabalho intelectual. Esta representação é construída por meio das qualificações:

[69]:

10 § 0 trabalho se tornou fundamental para a sobrevivência no contexto capitalista pós-industrial, [...]. Há tempos acreditava-se que o [...] avanço tecnológico, [...] pouparia o ser humano de tanto trabalho, mas a realidade é bem diferente. [...] as funções se especificaram num mercado de trabalho exigente, deixando a escolha por uma carreira mais difícil.

2o § [...]. É comum vermos engenheiros, médicos e professores trabalhando em funções diferentes das suas formações. Mas o pior mesmo fica para aqueles que não tem acesso a um estudo, a uma formação devido a posição sócio-econômica desfavorável, ficando à margem da sociedade, acelerando o quadro da desigualdade social.

3o § [...]. A solução está na educação, porque só quem tem a oportunidade de se formar e estudar está mais apto para o mercado de trabalho, e também na escolha da carreira que condiz com as habilidades individuais, [...]. (R119, grifos meus).

Nessa redação, a qualificação do trabalho se dá numa progressão em direção a um argumento fortalecido pela adjetivação avaliativa e axiológica, já no primeiro parágrafo. O escrevente retoma um dos PDVs do segundo fragmento da coletânea, em que o enunciador afirma o fracasso do progresso em acabar com o trabalho:

Há algumas décadas, pensava-se que o progresso técnico e o aumento da capacidade de produção permitiriam que o trabalho ficasse razoavelmente fora de moda e a humanidade tivesse mais tempo para si mesma. [...]. (PROVA DE REDAÇÃO, FUVEST, 2006, trecho do segundo fragmento, grifos meus).

O escrevente reconhece esse PDV e parte dele para construir outro. Ainda no primeiro parágrafo da redação, há um enunciador que aponta para onde 
direcionará seu argumento, mas não o revela totalmente, ao afirmar que a escolha da carreira ficou mais difícil com a exigência de especificidade do mercado de trabalho. Partindo desse PDV, o escrevente, no uso de uma adjetivação bem marcada, começa a construir um PDV: "Com o avanço tecnológico as funções se especificaram num mercado de trabalho exigente, deixando a escolha por uma carreira mais difícil". Nessa construção, já não cabe mais o PDV tomado da coletânea. Entra em cena, agora, o enunciador que tenta fazer valer a escolha certa de uma carreira, para cumprir o exigido pelo mercado de trabalho, projetando no enunciado a enunciação, pelo menos indiretamente, ao tratar da escolha da carreira, uma vez que essa escolha é feita pelo escrevente.

A dificuldade de escolha da profissão é qualificada e fortalecida pelo uso do intensificador mais: "deixando a escolha por uma carreira mais difícil". A consequência disso é explicitada no parágrafo seguinte, em que é encenado outro enunciador que corrobora o que vinha sendo construído no parágrafo anterior:

[70]:

É comum vermos engenheiros, médicos e professores trabalhando em funções diferentes das suas formações. (R119, grifos meus).

Por meio da adjetivação, o argumento anterior é fortalecido: o aumento da dificuldade em escolher uma carreira que seria a correspondente a um mercado mais exigente. Esse fortalecimento se dá pelo efeito de sentido propiciado pela adjetivação: "é comum", que revela a alta frequência de trabalhadores especialistas atuando no mercado de trabalho em funções "diferentes" daquelas de sua formação. Por isso, não basta ter uma profissão, exige-se ter a profissão certa. É nesse sentido que a escolha de uma carreira é mais difícil.

Na progressão da argumentação, a construção desse PDV é intensificada na direção de um PDVD com o uso da comparação adjetiva:

[71]:

Mas o pior mesmo fica para aqueles que não tem acesso a um estudo, a uma formação devido a posição sócioeconômica desfavorável, ficando à margem da sociedade (R119, grifos meus). 
Nessa comparação, a intensificação da adjetivação dada pela adjetivação superlativa, articulada com a adjetivação avaliativa, marca um posicionamento dominante ao qualificar "aqueles que não tem acesso a um estudo, a uma formação" no sentido de se sobrepor aos demais PDVs. O enunciador mostra de que lugar ele enuncia, ao enunciar desse modo tão contundente, tão fortemente marcado pela adjetivação.

No parágrafo conclusivo, a construção do PDVD é finalizada, quando o enunciador retoma o tema da formação e modaliza a afirmação "A solução está na educação", ao enunciar a educação como o único meio de resolver o problema do trabalho:

[72]:

A solução está na educação, porque só quem tem a oportunidade de se formar e estudar está mais apto para o mercado de trabalho (R119, grifos meus).

Como resultado dessa formação, enuncia-se que o trabalhador torna-se "mais apto para o mercado de trabalho". Novamente, a adjetivação intensificada articulada com a modalização corrobora a construção do PDVD. Há, nesse sentido, um jogo enunciativo em que prevalece a voz que valoriza o trabalho intelectual, visto na perspectiva da universidade, uma vez que é por meio dela que se obtém a formação qualificada. É um posicionamento em que prevalece o jogo ideológico que revela a representação social do trabalho intelectual: só por meio do ensino superior, isto é, da educação formal nesse nível é que o sujeito se torna apto para atuar no mercado de trabalho.

Esse modo de construir o PDVD é bastante recorrente nas redações e, para mostrar um pouco mais dessa incidência, apresento o exemplo [73], para mostrar de que maneira a adjetivação avaliativa e axiológica participa da construção desse PDV e dessa representação social da universidade. Nesse exemplo, a adjetivação também é bastante marcada e evidencia posicionamentos bem definidos. Por meio da adjetivação avaliativa e axiológica articuladas com algumas modalizações, entram em cena enunciadores que mostram de que maneira prevalece a valorização da educação e dos estudos de modo geral:

[73]:

2o $§ \quad[\ldots]$ a falta de emprego, resultado da precária 
escolaridade e da mecanização de tudo. Cada vez mais, o trabalho é restrito àqueles mais bem preparados - os que tiveram ensino particular, estudaram em ótimas universidades, falam outras línguas.[...]

4 $\S[\ldots]$ a chance, a oportunidade não está em um estado.

5 $§$ Está na mudança da base de tudo: educação. [...].

[...] apoiar o estudo, os cursos profissionalizantes e todos os outros, é o que o Estado tem de fazer. A sociedade pode e deve colaborar, e é mais simples do que se imagina: [...] (como voluntário nas escolas, ensinando algo, oferecendo um trabalho) [...].

7으 $\mathrm{E}$ aí, quem sabe os noticiários e as ruas nos mostrem coisas mais felizes (R061, grifos meus).

No exemplo [73], pode-se perceber como o escrevente constrói tanto uma imagem de si - alguém que valoriza sobremaneira a educação e deposita nela a solução para os problemas sociais - quanto daquele que é seu interlocutor, a banca corretora, que representa a universidade. Ao valorizar o estudo, de modo geral, seja aquele mais formal - 0 da escola particular, o da universidade - seja aquele menos formal - "como voluntário nas escolas, ensinando algo" -, o escrevente perpetua sua representação da universidade como a instituição que irá dar conta dos problemas sociais, como os citados no início da redação: "Especialmente no Brasil, vemos nos noticiários e nas ruas, diariamente, pessoas com fome, doentes, crianças nos semáforos, barracos sem condição nenhuma [...]", por ser ela a instituição que detém o poder da formação mais valorizada na sociedade.

As adjetivações presentes no exemplo [73] evidenciam sua importância na construção do PDVD, no que se refere principalmente à constituição do argumento e da orientação argumentativa da redação como um todo. Destaco, desse exemplo, a importância também dos substantivos carregados de valores, e que igualmente contribuem para a construção do PDVD neste texto, uma vez que, por meio deles, pode-se depreender a representação social da universidade, bem como do papel do trabalho intelectual nesta valorização.

No exemplo [74], abaixo, a construção do PDV que valoriza a educação e os estudos é depreendida tomando como percepção a presença de determinados verbos, principalmente dos verbos no infinitivo, uma vez que a adjetivação é pouco presente nesse exemplo. Como já dito anteriormente, todas as palavras são carregadas de valores quando enunciadas. Vale destacar este exemplo principalmente para mostrar como os diferentes trabalhos são qualificados e como 
essa qualificação é também axiológica, como nas adjetivações mostradas nos exemplos anteriores:

[74]:

2 § Pode-se interpretar o trabalho como a expressão do pensamento humano. [...].

3 § Dentre as formas de expressão do pensamento, pode-se citar as obras literárias, pinturas, esculturas, composições musicais, obras de arte em geral; obras de engenharia civil, invenção de remédios e descoberta de curas de doenças. Enfim, cada carreira profissional consiste em realizar um ou mais tipos de trabalho.

4 $§[. .$.$] o trabalho das massas populares consiste em_fazer$ parte de uma linha de produção, executando movimentos repetitivos.

$5^{\circ} \S$ Infelizmente não foi dada a essas pessoas a oportunidade de estudar e aprender a pensar. Elas não têm instrução para realizar a expressão de seu pensamento.

6 § Conclui-se, então, que é necessário para cada um de nós receber instrução quando jovem e quando adulto, já saber pensar, filosofar para seguir uma carreira profissional com sucesso e realizar grandes trabalhos (R007, grifos meus).

No exemplo [74], quando o escrevente se refere ao trabalho intelectual, valoriza-o, utilizando o verbo "realizar" e qualifica-o como "a expressão do pensamento humano". Quando faz referência ao "trabalho das massas populares", isto é, o que seria o trabalho braçal, se opondo ao intelectual, faz uso do verbo "fazer", depreciando-o por meio de uma qualificação negativa, como em "fazer [...] "movimentos repetitivos". Por meio desses verbos entram em cena dois PDVs que se opõem, gerando um conflito que será resolvido pela oportunidade de estudo a quem desempenha trabalho repetitivo. O efeito de sentido do uso desses dois verbos revela o posicionamento que o escrevente está construindo em direção a uma argumentação mais incisiva, constituída pelo uso de outros verbos carregados axiologicamente de uma carga positiva, como "estudar e aprender a pensar", para "realizar a expressão de seu pensamento". Trata-se de um PDV preconceituoso, uma vez que revela a concepção de linguagem como expressão do pensamento, isto é, apenas aquele que estudou é capaz de pensar.

A representação social do trabalho e do trabalho intelectual em jogo, nessa redação, é a de que a educação formal propicia uma boa carreira, porque o trabalho é realização, ao contrário de quem não estuda, cujo trabalho consiste em executar 
movimentos repetitivos, ou seja, é repetição. São duas forças antagônicas concorrendo entre si e que buscam um lugar. O escrevente, para corroborar seu posicionamento, introduz um enunciador, mobilizado da esfera religiosa e atualizado na enunciação para finalizar e concluir seu texto: o jovem deve "receber instrução" para "pensar, filosofar para seguir uma carreira profissional com sucesso e realizar grandes trabalhos" (R007, grifos meus). Fica claro, no exemplo [74], que a qualificação do trabalho foi efetivada na axiologização desses verbos, constituindo outro modo de dizer o mesmo dito, isto é, a qualificação positiva do trabalho conquistado por meio do estudo.

A qualificação, nesse exemplo, mantém a mesma representação social do trabalho intelectual e do que ele representa para o escrevente, frente à universidade. Circula, desse modo, um discurso preconceituoso em relação ao trabalho braçal. Preconceito herdado da época da escravidão, por meio do qual se legitima o poder da educação formal para dividir e excluir quem não tem acesso a ela, como pode ser observado nos exemplos [75] e [76]:

[75]:

Verifica-se, pois, que o melhor investimento a ser feito pelos países e mesmo por cada pessoa é na educação, já que os excluídos de hoje e do futuro serão os que não souberem se preparar adequadamente, nesta nova era já batizada de a "do conhecimento" (R212, grifos meus).

[76]:

O serviço manual foi e ainda é visto por algumas pessoas, algo que denegride o homem. É feito por pessoas que não tem ou não buscaram a oportunidade de estudar e acabam aceitando o trabalho pesado (R022, grifos meus).

Em síntese, as representações do escrevente sobre a universidade evidenciam-se a partir do jogo discursivo entre duas formações discursivas, cujos discursos sobre educação/ estudos/ formação se dividem em duas posições: uma, que afirma que quem tem estudo tem bom trabalho; outra, que afirma que quem não tem estudo não vai para frente, não evolui, porque não consegue bom trabalho. Tudo se consegue por meio do trabalho, mas de um trabalho resultante de um bom estudo, de uma boa formação. Nesse jogo discursivo, cria-se um efeito de sentido, em direção ao outro, de que, com educação/estudo, tudo se resolve. Esse efeito faz transparecer a ideologia ali enunciada, revelada por meio da qualificação do trabalho 
intelectual e do que representa para o escrevente a posição hierarquicamente superior da universidade, aliás, a que o escrevente julga ser a defendida por ela. Para o escrevente a universidade representa o próprio trabalho intelectual.

As representações descritas neste item são norteadoras de um discurso em que a direção argumentativa traz à tona a imagem que o escrevente tem da universidade, ao valorizar o trabalho artístico, supondo ser este o que a própria universidade valoriza, uma vez que foi o único tipo de trabalho mencionado nos fragmentos. Ao valorizar o trabalho intelectual em detrimento dos demais, o escrevente, além de assumir esse PDVD, constrói certa imagem de si, a partir da imagem que ele faz da universidade: a imagem positiva de um sujeito que igualmente valoriza o trabalho intelectual e, por isso, merece um crédito da universidade: a aprovação no exame vestibular.

\subsection{A construção do PDVD e sua relação com saberes provenientes de outras esferas}

A construção do PDVD é vista neste item por meio da relação dos textos dos vestibulandos com saberes provenientes de outras esferas, isto é, esferas diferentes daquela representada pela prova de redação, a escolar (em suas dimensões escolar propriamente dita, burocrática e ficcional). Desse modo, esferas são vistas como outras fontes das quais o escrevente pode se valer. Essas fontes podem ser provenientes dos diferentes letramentos e atividades sociais vivenciadas pelo escrevente. Saliento que essa relação não exclui o diálogo do escrevente com a coletânea, mas a hierarquização dos PDVs não está diretamente ligada aos fragmentos da coletânea; sem que deixe de estar, de certa forma, investida da proposta de redação.

$\mathrm{Na}$ totalidade do corpus, pude depreender saberes provenientes de diferentes esferas, embora dificilmente se possa ser exaustivo em relação a saberes/esferas, podendo, portanto, restar aqueles não depreendidos pela pesquisadora. As esferas selecionadas para análise foram oito, tendo como critério aquelas que foram mais salientes para o diálogo com a construção do PDVD. Elas estão relacionadas às 
vivências do escrevente ligadas ao mundo escolar, ao mundo do trabalho, ao mundo da literatura, da saúde, da filosofia, da religião, da mídia, da música etc.

Os posicionamentos do escrevente são tomados, neste ponto, em função dos enunciadores que o escrevente julga pertinente introduzir nos enunciados, para construir imagens de si e de seu outro, para efetivar-se, igualmente, como crítico e como portador de conhecimentos para a banca corretora. Em função dessas imagens, recorre à polifonia de autoridade ${ }^{67}$, em que entram em cena enunciadores que exprimem diferentes vozes julgadas pelo escrevente como de autoridade, para fortalecer o PDV que está construindo.

\section{A. Os saberes projetados pela enunciação no enunciado}

A projeção da enunciação no enunciado é vista, na análise das redações, como uma estratégia argumentativa em que o escrevente se mostra presente por meio da referência direta ou indireta à enunciação, para defender uma posição no discurso que enuncia. A posição de alguém que desempenha um papel social nessa enunciação. No exemplo [77], os PDVs são construídos na articulação da adjetivação modalizada com saberes de diferentes esferas. Já o PDVD é construído a partir da constituição da projeção da enunciação no enunciado, por meio do uso da expressão "esta dissertação propõe". No primeiro parágrafo da redação está presente um tom de veracidade herdado da presentificação do enunciado formulada pelo uso do tempo presente. O uso do tempo presente articulado com a adjetivação deôntica, "é preciso", cria um efeito de necessidade intrínseca ao que se está enunciando, explicitada pela adjetivação construída pelo uso da relativa, no final do parágrafo:

[77]:

1ㅇ § Há um provérbio popular que afirma "O trabalho dignifica o homem". Acreditar nele pode ser encontrar a razão para acordar pela manhã [...]. Na história contemporânea, trabalhar é preciso para ganhar o dinheiro que paga o almoço e o café (R159, grifos meus).

\footnotetext{
${ }^{67}$ Expressão baseada na expressão de Ducrot (1987), "argumento de autoridade", que por sua vez procede da expressão "argumentação de autoridade" da retórica tradicional. Segundo Norén (2000, p. 34), "a argumentação por autoridade repousa sobre a idéia de que o locutor evoca [...] um ser discursivo diferente dele [mas instituído de autoridade], a fim de persuadir seu alocutário de um ponto de vista".
} 
Ao mobilizar um saber popular, o provérbio, o escrevente põe em cena um enunciador que introduz um PDV, no qual ele vai se apoiar para construir o seu, como se mostrará no parágrafo conclusivo. No segundo parágrafo, põe em cena outros enunciadores e cria um jogo enunciativo, buscando, em vários PDVs, o que julga pertinente para construir o seu PDV. Essa busca se dá a partir da coletânea, mas nela não se fixa, circulando por diferentes esferas, como se vê no exemplo [78]:

[78]:

2 ○ Já foi dito também que o trabalho é uma invenção [...] $\underline{e}$ ainda que o progresso traria [...]. Há quem diga até que o ócio é importante [...]. Mas o que se ouve, hoje em dia, é que é preciso [...]. É necessário estar atento às novas informações e tecnologias [...] (R159, grifos meus).

Ainda no segundo parágrafo, o escrevente, por meio da adjetivação deôntica "É necessário estar atento às novas informações" introduz outro PDV para construir uma imagem positiva de si, um sujeito que, além de reconhecer a dignidade que o trabalho proporciona e foi tirada do trabalhador pela modernização, é também um sujeito bem informado, esclarecido e que age em prol disso, quando outros dois enunciadores são postos em cena com esse mesmo PDV, no parágrafo seguinte. O escrevente fica lado a lado com eles: os "especialistas na área da saúde" e o "escritor Carl Honré", ambos denunciando o avanço moderno com algo prejudicial:

[79]:

3o § Especialistas na área da saúde apontam a sede de velocidade responsável pelo [...], estresse, estafa e síndrome do pânico e suas variações. O escritor Carl Honoré propôs em seu livro "Devagar" a desaceleração dos processos humanos (R159, grifos meus).

O primeiro enunciador introduzido parafraseia um slogan da propaganda do Ministério da Saúde, "o ministério da saúde adverte", usando a mesma fórmula e tom: "Especialistas na área da saúde apontam [...]". Por meio da inserção desse outro discurso, mostra-se, o tempo todo, em seu trabalho com a linguagem. $O$ recurso ao discurso do outro é usado para fortalecer a construção do seu discurso, que é exibido na sequência desse mesmo parágrafo:

[80]:

3ㅇ Esta dissertação propõe o resgate da dignidade [...] (R159, grifos meus). 
Por meio de uma inserção metadiscursiva, o escrevente se coloca no texto, como se vê, no exemplo [105]. Pode-se observar também a marcação da presentificação no texto, para firmar, em tom denunciador, um PDV que defende. E, para isso, por meio do enunciador "esta dissertação", faz a proposta de resgatar a dignidade perdida com o trabalho moderno. Ao usar a expressão "Esta dissertação", o escrevente tenta se distanciar do seu dizer, do que enuncia, uma vez que não se utiliza explicitamente do "eu", primeira pessoa, demonstrando objetividade, exigência do gênero; mas, ao mesmo tempo se aproxima do que enuncia, porque quem escreve a dissertação é ele, escrevente.

O escrevente tenta mostrar para seu interlocutor que conhece os critérios de correção da prova de redação, isto é, conhece a exigência da prova, que é saber argumentar por meio da escrita de uma dissertação, conforme solicitado na instrução da prova. Ele responde a essa exigência, evidenciando que escreve efetivamente uma dissertação, sendo que nela estão presentes argumentos de autoridade, construídos com os discursos do outro e em função desse interlocutor. Assim, quer evidenciar a imagem de alguém que possui uma opinião e que pode contribuir para o resgate tão necessário da dignidade que o trabalho pode propiciar aos trabalhadores. Há, desse modo, um jogo enunciativo em que objetividade e subjetividade deslizam e se cruzam, resultando num efeito polifônico de um discurso que quer se mostrar objetivo, mas evidencia a subjetividade marcada no texto, para assumir um PDV.

O escrevente insere no texto diferentes enunciadores, com diferentes posicionamentos. Desse modo, seu posicionamento é assumido na retomada de outros posicionamentos de que ele se utiliza do discurso relatado: "Há um provérbio popular que afirma"; Já foi dito também que o trabalho é uma invenção histórica"; "Há quem diga até que o ócio é importante"; "Mas o que se ouve"; "Especialistas na área da saúde apontam a sede de velocidade responsável pelo surgimento de avanços modernos"; "O escritor Carl Honoré propôs em seu livro"). Após introduzir todos esses enunciadores e relatar seus posicionamentos, o escrevente constrói o seu PDV: "Esta dissertação propõe". Ele se mostra novamente como um sujeito leitor e bem informado, exigência feita a um bom candidato a uma vaga em uma universidade considerada de ponta no Brasil. 
Nesse modo de construir PDVs, a qualificação do trabalho está mais evidente no uso de alguns verbos e de alguns substantivos. No uso do verbo "dignificar" em "O trabalho dignifica o homem", o escrevente faz valer a significância do provérbio, qualificando o trabalho positivamente, assumindo a voz coletiva que dele ecoa. No uso de alguns substantivos, o escrevente faz valer um PDVD, que é constituído na correlação com outros PDVs:

[81]:

Esta dissertação propõe o resgate da dignidade como razão para o trabalho, e sendo assim, a felicidade a motivação para acordar pelas manhãs ir para o trabalho [...] (R159, grifos meus).

Na sequência, exemplo [82], o escrevente valoriza o trabalho intelectual, por meio da modalização deôntica devem ser e da adjetivação, feita pelo uso da relativa composta pelo substantivo carregado de valores, felicidade, como se pode observar:

[82]:

Conclui-se então, que graduação e derivados devem ser caminhos e instrumentos que levam o indivíduo a felicidade [...] (R159, grifos meus).

Vale destacar que o uso da expressão metaenunciativa "Esta dissertação" muda a direção do PDV que vinha sendo constituído no desenvolvimento da redação, isto é, a exposição de vários PDVs. E a construção do PDV é direcionada para o PDV do examinador, que chamo PDV do destinatário, exatamente para chamar sua atenção para o que se enuncia por meio do gênero que é exigido pela banca. As outras vozes enunciadas provêm de enunciadores diferentes, mas elas convergem para uma voz única, reforçada pelas vozes coletivas do provérbio. $O$ escrevente joga com essas vozes, criando um efeito polifônico, para, ao final de seu texto, mostrar a voz que prevalece, a do sobreenunciador, isto é, do PDVD: o resgate da dignidade que o trabalho, conquistado com estudos formais: "graduação e derivados", proporciona. Em sua análise, texto (R159), exemplos [77] a [82], o escrevente mobiliza saberes de diferentes esferas, para construir o PDVD, isto é, o constrói na relação com outros pontos de vista, destacando a projeção da enunciação no enunciado. 
Há, no corpus, outros exemplos em que a enunciação é projetada no enunciado. Tomo trechos de duas redações, a título de reforço desse tipo de ocorrência:

[83]:

Outro fator que mostra esse enraizamento [do trabalho] é o treinamento a que somos submetidos, desde crianças, para seguirmos alguma profissão, aprendendo matérias que serão uteis para as mesmas, ou para nos ajudar a atingi-las, como exemplo passar no vestibular (R171).

[84]:

Ao completarmos o Ensino Médio nos surge a maior das dificuldades da adolescência: o Vestibular. Nesse momento estamos decidindo o rumo de nossa vida profissional (R126).

Como se vê, o escrevente faz referência explicita ao exame vestibular, ligando-o ao trabalho, à vida profissional que ele poderá proporcionar. Trata-se, nesse sentido, de uma projeção da enunciação mais direta, mas também direcionada para o posicionamento que o escrevente está construindo, o da valorização do estudo para se conseguir um bom trabalho.

\section{B. Os saberes e a esfera literária}

Outra esfera presente nas redações é a literária. Ela está diretamente ligada com a esfera escolar, uma vez que a escola é o lugar previsto, em princípio, para o estudo da literatura. $O$ aluno passa na escola, antes do exame vestibular, em média, 11-12 anos. Nesses anos, o trabalho com a literatura é, embora não suficientemente, presente e se aprofunda no Ensino Médio. Presume-se, então, que o escrevente tenha tido, no decorrer desses anos, algum contato com diferentes gêneros dessa esfera, seja por meio da leitura ou da escrita, ou mesmo por meio de outras esferas correlatas, como a cinematográfica e teatral.

$\mathrm{Na}$ escola, circula um discurso que valoriza a literatura, colocando-a como parâmetro para a boa escrita. Esse discurso, que também está presente no senso comum, pode ser considerado, nesse sentido, como um discurso de autoridade. $O$ escrevente sempre ouve: "é preciso ler escritores clássicos para escrever bem", "deve-se escrever com base na escrita dos grandes escritores", dentre outros exemplos nesse mesmo tom. Desse modo, o escrevente foi condicionado a ver o 
endeusamento da literatura pela escola e pela sociedade. Sabendo que está sendo avaliado, e por meio de sua escrita, ele recorre ao saber autorizado por esses discursos, para validar seu texto. Essa mobilização mostra o tipo de imagem que quer que seu interlocutor depreenda dele: a imagem de alguém que conhece a literatura e a valoriza, traduzindo-a na imagem de um bom leitor.

Em função dessa imagem, quase como uma projeção da enunciação, o escrevente mobiliza um saber literário vinculado principalmente a seu letramento escolar, ao introduzir, por exemplo, no texto, a referência às obras ou aos autores solicitados na bibliografia de leitura para o exame vestibular:

[85]:

Trabalhar é algo necessário, em tese. Conhecemos a personagem "Brás Cubas" de Machado de Assis, por exemplo, que viveu normalmente sem trabalhar, porém sabemos que esta até pode ser a realidade de famílias ricas, pois na maioria da população que é pobre isto é impossível de ocorrer. [...] (R065, grifos meus).

[86]:

Mas, sem dúvida, o trabalho purifica e acrescenta aos homens, porém a vida está repleta de heróis como Macunaíma, que deitam em uma rede a espera de tudo pronto, a eles o que resta é a ignorancia, o secar da sabedoria e com certeza a falta de coragem para lutar e tentar conseguir (R153, grifos meus).

[87]:

O tempo ou o passar do tempo, se encarrega de transformar o trabalho e seus objetivos, intelectual ou braçal, por domínio ou por dinheiro. Se for por dinheiro não pode ser trabalho artístico, [...]. Como recompensar Camões por Os Lusíadas? E como negar que algo tão sublime é trabalho? (R234, grifos meus).

Os exemplos [85 a 87] mostram que o escrevente mobiliza saberes da esfera literária, ao fazer referência, principalmente aos autores ou às obras que supõe conhecidos do interlocutor, tem em vista o que lhe é exigido no exame vestibular: "O candidato deve, portanto, [...] possuir um certo repertório de leituras de textos literários, no nível próprio do concluinte do Ensino Médio" (FUVEST, 2006, Manual do Candidato, p. 42). Em alguns casos, o escrevente, ao construir uma imagem 
positiva de si, como alguém que leu efetivamente a obra solicitada, dá detalhes delas:

No que se refere aos textos literários, espera-se o conhecimento das obras representativas dos diferentes períodos das literaturas brasileira e portuguesa. [...]. Esse repertório de leituras inclui [...] Machado de Assis (Memórias póstumas de Brás Cubas), Mário de Andrade ([...], Macunaíma [...]), [...] Camões (Poesia lírica: sonetos; poesia épica: episódios [...] de Os Lusíadas (FUVEST, 2006, Manual do Candidato, p. 42).

Nesse sentido, mobiliza saberes que julga de autoridade e, ao mesmo tempo, saberes valorizados pela instituição escolar e principalmente pela universidade que solicita essas leituras em seu exame. Trata-se de um sujeito que tem a ilusão de, por meio da mobilização de saberes da esfera literária, construir a imagem de um bom leitor, como é exigido pela universidade e de valorizar o que ele supõe que a universidade valoriza.

Há, ainda, a mobilização de saberes da esfera literária, mas não diretamente vinculada à escola básica, pelo menos não necessariamente, como no exemplo [88]:

[88]:

[...] intitulado "A alma do homem sob o Socialismo", escrita pelo irlandês Oscar Wilde. Nesse, Wilde prevê uma utopia artística, na qual homens serão dispensados de seus empregos para que passam se dedicar a suas habilidades criativas de forma livre de qualquer tirania e tédio. Isso só virá com a melhoria das máquinas, que farão todo o trabalho indesejado e com uma revolução, na qual os excluídos da sociedade atual se levantarão e irão exigir os seus direitos a uma vida mais digna e melhor (R248).

No que se refere à construção do PDVD e a mobilização de saberes da esfera literária, o escrevente assume um PDV correlacionado com outros PDVs, para construir, assim, um PDVD, como no exemplo [89]:

[89]:

O motor da história

1 $\S$ As diferentes visões acerca do trabalho [...]. Desse modo, cada cultura cunhou seu próprio conceito de trabalho que se perpetua e se transforma ao longo de sua história.

2 § O conceito de trabalho, tal como o concebemos hoje, [...]. Assim, a sociedade que antes produzia para seu próprio sustento, agora é alvo de exploração, [...]. Adous Huxley, em seu livro "admirável mundo novo", configura uma situação futurística. [...]. 
3o § Se por um lado, a previsão de Huxley parece assustadora; por outro, a situação atual não é de grandes perspectivas. Durante a modernidade, [...] avanços técnicos [...], todo esse aparato foi usado contra o trabalhador, o qual passou a concorrer com o trabalho das máquinas e, por vezes, com o sub-emprego.

4 - $\S[\ldots]$, existe ainda um outro tipo de trabalho que é de natureza artística, [...] do homem de expressar seus sentimentos e de revelar o seu talento [...], como foi o caso de Camões que escreveu a extensa obra "Os Lusíadas" e de Michelangelo que despendeu anos para fabricar uma escultura de mármore.

5o § A execução do trabalho, através dos [...], revelam a natureza das ações do homem, [...] concorrem para o entendimento do trabalho como "o grande motor da história" (R255, grifos meus).

No exemplo [89], como nos demais em que o escrevente dialoga com a mesma ordem dos textos da prova de redação, "As diferentes visões acerca do trabalho" e, na sequência, responde ao enunciador do primeiro fragmento, por meio da relativa, afirmando que o trabalho não vai acabar e se transforma no decorrer da história. Nos segundo e terceiro parágrafos, o escrevente contextualiza o trabalho no diálogo com o segundo fragmento e introduz um enunciador, Aldous Huxley (na redação Adous), que configura o trabalho em uma perspectiva futurística. O PDV desse enunciador corrobora o PDV do segundo fragmento. Mantendo a mesma ordem da coletânea, dialoga com o terceiro fragmento antes de enunciar o parágrafo conclusivo. No quarto parágrafo, é introduzido um enunciador cujo PDV valoriza o trabalho de arte, que pode ser percebido nos trechos: "existe ainda um outro tipo de trabalho que é de natureza artística, [...] do homem de expressar seus sentimentos e de revelar o seu talento". Para fortalecer esse PDV, entra em cena um enunciador que valoriza o trabalho de arte, por meio da referência à literatura: "como foi o caso de Camões que escreveu a extensa obra "Os Lusíadas'" e finaliza com a retomada discursiva do terceiro fragmento, fazendo referência ao trabalho de Michelangelo.

Trata-se de um texto com poucas adjetivações, mas na adjetivação de "Os Lusíadas", como "extensa obra", o escrevente constrói uma imagem de si, de conhecedor da literatura solicitada presumidamente pelo corretor, anunciando que detém conhecimentos dessa obra. Nesse sentido, o escrevente dialoga com seu interlocutor para construir o PDV dele. Finaliza o parágrafo conclusivo com a 
adjetivação do trabalho, qualificando-o positivamente, com um adjetivo dimensional e anteposto: "o grande motor da história", o que valoriza ainda mais a qualificação positiva do trabalho. O uso das aspas mostra, apesar de todo esforço do escrevente em construir esse PDV, que esse posicionamento não é o dele, embora o assuma para si.

A mobilização de saberes da esfera literária funciona como estratégia para construir a imagem de um bom leitor, como se exige de todo estudante e, sobretudo, de um candidato que pretende cursar o ensino superior na Universidade de São Paulo. A mobilização desses saberes contribui para a construção do PDVD, no sentido da valorização do trabalho intelectual, por meio de saberes que o escrevente julga ser valorizados por ela. Tem-se, pois, na construção do PDVD, um movimento enunciativo em que vários posicionamentos se marcam no texto. Escrevente e interlocutor se constituem mutuamente, por referência a lugares sociais já existentes: o candidato, que deve provar sua competência para ser aprovado; e o examinador, que deve aprovar o candidato melhor preparado. Nessa construção, têm-se, também, movimentos discursivos que, a partir do imaginário social do escrevente, estabelecem o estatuto do candidato bem preparado e que deve ser aprovado no exame.

\section{Os saberes e a esfera popular}

O provérbio circula na esfera popular, pois faz parte da "sabedoria do povo". Entretanto, ele possui um caráter religioso no sentido de "sentenciar" (MAINGUENEAU, 2002) e ditar comportamentos, carregando em si uma dimensão moral e social. Segundo Candido (2004, p. 94), o provérbio "reveste um caráter frequentemente semirreligioso de sentença e oráculo, quase sacralizando as normas de sustentação do grupo". A sua repetição reflete uma autoridade e seu uso valida (ou tentar validar) um discurso. Desse modo, os provérbios serão analisados em dois momentos: na esfera popular e na esfera religiosa (item "D”). Essa decisão se baseou mais na esfera de circulação dos provérbios analisados, e não somente em sua dimensão moral e social. O provérbio "o trabalho dignifica/enobrece o homem" e suas reverberações serão analisados neste item, esfera popular. Já o provérbio "comerás com o suor do teu rosto", fruto do mito bíblico de Adão e Eva, será 
analisado na esfera religiosa. Há, ainda, no corpus, outros provérbios, frases prontas, slogan, mas para a análise priorizei esses dois.

Nas redações, o recurso aos provérbios é uma estratégia em que o escrevente se apoia para validar seu discurso. Ele recorre a uma voz universal, que por sua vez é também coletiva e, a partir delas, tenta compor a sua voz, um PDV. Segundo Maingueneau (2002, p. 169), "A enunciação proverbial é fundamentalmente polifônica; o enunciador apresenta sua enunciação como uma retomada de inumeráveis enunciações anteriores, as de todos os locutores que já proferiram aquele provérbio", por isso, o provérbio é um modo especifico de dizer o discurso do Outro, tomado para construir o seu discurso.

Outra especificidade do provérbio é a sua "relação especial com a situação de enunciação" (ROCHA, 1995, p. 138). É comum, nas orientações didáticas a respeito da escrita do gênero redação de vestibular, o repúdio ao uso de clichês ou frases prontas, incluindo aí os provérbios (cf. GRANATIC, 1999). Entretanto, não é o que se vê nas redações. O recurso ao uso de provérbios, frases prontas, slogans foi bastante utilizado pelos escreventes, equivalendo a $27 \%$ do corpus.

A presença desse recurso, no corpus, manifesta-se de diferentes maneiras e, na maioria das vezes, há uma tentativa de apagamento do enunciador fonte, pela ausência de aspas ou pelo recurso à paráfrase. Na não explicitação da fonte responsável pelo dizer, o enunciador passa a ser um coenunciador no sentido de assumir a responsabilidade pelo que se enuncia, juntamente com um enunciador universal, a sabedoria popular, em que o escrevente busca autoridade exatamente por sua universalidade, pois o que é dito é um já-estabelecido. É essa estabilidade, a do que já foi dito, que faz o escrevente recorrer aos provérbios, para validar o seu dizer e construir um PDV que se sobreponha a outros PDVs ali também presentes. O recurso ao uso do provérbio "o trabalho dignifica o homem" prevalece nas redações, primeiro porque é o PDV depreendido dele que o escrevente aposta para sobrepô-lo aos demais; segundo, porque essa aposta está ligada às imagens que ele constrói de seu interlocutor e de si, a imagem de alguém que valoriza o trabalho porque ele dignifica o homem. 
Encontrei, nas redações, a captação e a subversão $0^{68}$ de diferentes provérbios. O provérbio "o trabalho dignifica o homem" é o mais recorrente na totalidade do corpus. Há PDVs que são construídos também nas contraposições e, desse modo, há redações em que esse provérbio é subvertido para a construção de um PDV que desvaloriza o trabalho. A análise está organizada, assim, em dois tópicos: um, em que trato da captação do PDV do provérbio, analisado em duas redações e; outro, em que trato da sua subversão.

\section{a. A captação do PDV do provérbio}

Nas redações há um modo de dizer predominante, cujo tom deôntico é o da valorização do trabalho de arte, visto como integrante do trabalho intelectual. Como já disse, o recurso ao uso do provérbio está ligado à situação de enunciação e, nesse sentido, esse tom deôntico é também trazido do provérbio, um tom "sentencioso" que é bastante marcado nas redações, principalmente nos parágrafos conclusivos.

No exemplo [90], o recurso ao provérbio é feito de modo explícito, isto é, há uma citação direta do provérbio, destacado entre aspas. Antes de chegar à referência direta ao provérbio, entram em cena enunciadores que qualificam o trabalho negativamente, ao tratar da disputa por emprego em um "mercado de trabalho cada vez mais exigente e competitivo" (trecho da redação R220). Nesse trecho, o PDV é dado pela qualificação com proposições negativas dos trabalhadores:

[90]:

1 $\S[. .$.$] A cada ano, milhões de pessoas disputam, como$ numa selva humana por uma vaga no mercado de trabalho cada vez mais exigente e competitivo, [...] pessoas menos instruídas e com menos chances, como por exemplo as pessoas que já "passaram da idade", acabam ficando à margem de uma realidade assustadora [...], muitas morrem de fome enquanto outras, trabalham tanto que mal têm tempo para comer [...] (R220, grifos meus).

\footnotetext{
${ }^{68}$ Termos tomados de Maingueneau (2002, p. 173, grifos do autor): "Captar um texto significa imitálo, tomando a mesma direção que ele. [...]. Por outro lado, há subversão quando o texto que imita visa desqualificar o texto imitado".
} 
Tem-se, no exemplo [90], um enunciador que introduz um PDV mobilizado da coletânea, segundo fragmento, e que se utiliza de uma adjetivação bem marcada, resultante de seu uso axiológico, para solidarizar-se com ele, enfatizando-o ainda mais. Entra em cena, nessas adjetivações, uma voz que revela a representação social que o escrevente tem das pessoas desempregadas: "pessoas menos instruídas e com menos chances" de conseguir um emprego; e a representação social das pessoas mais velhas, mas que ainda buscam espaço no mercado de trabalho, aquelas que "já 'passaram da idade'. Nessa direção, segundo o PDV tomado da coletânea, o mercado de trabalho é cruel, pois não dá chances às pessoas nessas situações, ou seja, quem não tem instrução ou quem tem mais idade. É validado um PDV que apresenta a valorização do trabalho conquistado por meio do estudo, isto é, quem tem estudos conquista um bom trabalho e não apenas um trabalho.

No segundo parágrafo, é encenado um enunciador que valoriza o trabalho de arte. Essa valorização é construída por meio do uso de substantivos carregados de valores positivos somados à adjetivação avaliativa fortalecida, ainda, pelo uso do intensificador:

[91]:

2o § [...] o trabalho do artista resulta de muito esforco, dedicação, entrega, paciência... e que pouco - a - pouco, resulta num dos aspectos mais importantes de nossa cultura a arte (R220, grifos meus).

Na sequência, no terceiro parágrafo, é introduzido um enunciador universal, um provérbio e a referência à fonte responsável por esse dizer:

[92]:

3 § "O trabalho dignifica o homem", já dizia a sabedoria popular (R220).

Ao enunciar o provérbio, o escrevente toma para si o valor que ele carrega, ou seja, a valorização do trabalho, por este dignificar o homem. Entretanto, ao enunciar "já dizia a sabedoria popular", ele se distancia da fonte enunciativa responsável por esse dizer, não assumindo totalmente essa responsabilidade, mas partilhando desse dizer. O escrevente busca um PDV que não é o seu, mas faz dele o seu PDV. Isto é, constrói um PDV na correlação com o PDV de outro, no caso, o da sabedoria popular. Ao mostrar isso em seu texto, o escrevente está se 
respaldando num dito já consagrado, porque re-dito e repetido pela sabedoria popular, ou seja, não só pelo que o provérbio diz, mas por sua enunciação frequente e numerosa. Assim, ele, ao se utilizar do modo de dizer formulado, de início, pelo advérbio de tempo já, em "já dizia a sabedoria popular”, está se respaldando não só no dizer do Outro, mas também num dizer que é constantemente re-dito e, por isso, cheio de valor, um valor universal, que é enunciado como valor de verdade.

Qual é esse valor de verdade? O uso do provérbio direciona o olhar para um aspecto específico do que é enunciado: a valorização do trabalho, porque dignifica o homem. Esse posicionamento assumido pelo escrevente é reforçado por meio da qualificação constituída na adjetivação fortalecida pelo uso do intensificador mais:

[93]:

Da mesma forma que o homem se torna mais responsável, digno, após conseguir um trabalho do qual possa obter sua independência financeira e seu sustento próprio, o artista se torna digno quando a ação de criar é consciente e voluntária, para que assim, sua obra seja designada como obra de arte (de R220, grifos meus).

Como se pode observar, no exemplo [93], a adjetivação axiológica revela de qual formação discursiva vem esse dito e esse modo de dizer. Se todo provérbio carrega o discurso da verdade, pode-se dizer que a verdade que esse provérbio carrega é a da ideologia capitalista que instaura o trabalho como elemento que dignifica o homem. Só se é digno trabalhando. Há, nesse sentido, um tom valorativo, que é reforçado por essa adjetivação. Entra em jogo, nesse dizer, a imagem que ele constrói e quer mostrar de si, como também a imagem que constrói de seu outro. Ele enuncia para essa imagem. Ao enunciar um provérbio, considera-se a enunciação universal e o conhecimento presumido de seu interlocutor sobre a importância da dignificação do homem por meio do trabalho:

[94]:

[...] o trabalho é peça fundamental na estrutura de uma sociedade e faz com esta, acompanhe e modifique-se conforme as necessidades humanas (parágrafo conclusivo de R220, grifos meus).

Há uma preocupação constante do escrevente com seu interlocutor. Por isso, ele inscreve esse sobreenunciador, manifestado linguisticamente por meio da adjetivação verbo ser + adjetivo e caracterizados pela presentificação. A qualificação 
se dá pelo que a ação verbal representa: o trabalho é fundamental, assim como as demais predicações contribuem para a valorização do trabalho. O escrevente busca, nessa adjetivação, uma posição equivalente a desse enunciador, isto é, a sobreposição e, ao enfatizá-la, constrói o PDVD no texto. Este é, então, construído na correlação com outros PDVs. Nesse caso, trata-se de um discurso da lógica capitalista, que foi incorporado no discurso do escrevente pelo uso do provérbio. É como se o provérbio, ou melhor, o discurso que nele é veiculado, tomasse conta do texto do escrevente. O uso do provérbio e a valorização do trabalho de arte trazem à tona a perpetuação de tradições: a da cultura popular, pela repetição do provérbio e do discurso nele veiculado e da cultura elitista, uma vez que é por meio de um único tipo de trabalho, isto é, o de arte ou o que seja similar a esse, como o trabalho intelectual dado pelo viés da formação acadêmica, que o homem será dignificado. $A$ repetição desse discurso contribui para a manutenção de uma ordem há muito estabelecida, uma vez que "o provérbio anula a iniciativa e impõe uma norma ideológica eternizada. Sufocação, portanto, de todos os modos, traduzida por um código petrificado" (CANDIDO, 2004, p. 103).

Esse mesmo provérbio se faz presente em outra redação, mas é posto de maneira diferente, porque o escrevente faz uso da subversão do provérbio, mas como apoio para manter o mesmo PDV captado do provérbio fonte. No exemplo [95], o escrevente parte do mesmo provérbio "O trabalho dignifica o homem" e, sem alterar a sua estrutura, subverte-o por meio da troca do verbo: "O trabalho danifica o homem", cujo PDV é oposto ao do provérbio fonte:

[95]:

1 $§ \bigcirc$ trabalho ao longo da história da humanidade teve seu carater determinado conforme as ideologias vigentes em cada época. [...]. E foi causa dos provérbios abaixo.

2 § $\bigcirc$ trabalho dignifica o homem.

$3^{\circ}$ § O trabalho danifica o homem (R198).

Vejo esse uso do provérbio como uma estratégia argumentativa do escrevente para fazer valer o posicionamento que ele vai construir em seu texto. Ele inscreve um enunciador que anuncia um discurso já posto, re-dito, marcado pela repetição da tradição popular e insere outro enunciador para contestar o PDV posto com o primeiro provérbio. 
O provérbio é, por excelência, a inscrição do Outro no discurso e, nesse caso, cria-se um jogo enunciativo com efeitos discursivos bem marcados. Esse jogo é apontado já no início da redação, quando o escrevente anuncia que são as ideologias que determinam o caráter do trabalho. $O$ jogo é estabelecido mais fortemente quando são inseridos dois enunciadores diferentes, marcados no texto pelo provérbio (segundo parágrafo) e por sua subversão (terceiro parágrafo), resultando num jogo enunciativo que conduz, a princípio, para um embate entre PDVs ligados ao modo como se valoriza o trabalho. Na progressão de seu texto, o escrevente passa a ajuizar sobre os dois discursos postos pelo provérbio, lançando uma pergunta retórica como estratégia argumentativa. Vê-se que o escrevente, pelo modo como conduz seu texto, demonstra constante preocupação com seu interlocutor, fazendo inserções metalinguísticas:

[96]:

40 § Para cada uma das afirmações acima existem adeptos. Mas qual será a certa? Para podermos responder de forma correta é preciso analisar a realidade das pessoas [...]. É claro que deve-se considerar que a escolha esteja relacionada com valores condicionados desde a infância [...] (R198, grifos meus).

A partir da inserção metalinguística, o escrevente se utiliza de uma qualificação deôntica: "é preciso" e um tom de certeza: "É claro que", o que evidencia os diálogos com seus interlocutores. Esse diálogo não se restringe ao corretor da prova, corresponde também à instrução da prova de redação, ao manual do candidato, que exigem capacidade argumentativa do candidato e um posicionamento claro.

Para a construção do PDVD, há um embate entre os PDVs introduzidos pelos enunciadores dos provérbios. Um, julgando o trabalho como prejudicial ao homem, isto é, o trabalho danifica o homem. Outro, em que o enunciador defende um PDV que valoriza, não o trabalho de modo geral, mas o trabalho de arte, como se pode observar nos exemplos [97] e [98]:

[97]:

5o § Contemporaneamente [...] então sendo humilhado, fazendo coisas que lhe desagrada, ou até mesmo sendo 
prejudicado fisicamente [...]. Pode-se afirmar então nesse caso que o trabalho é prejudicial ao homem (R198, grifos meus).

No exemplo [97], a adjetivação tem um caráter axiológico que, reforçada - “ até mesmo sendo prejudicado fisicamente" -, amplifica o PDV tomado do segundo fragmento. A última adjetivação, a que qualifica o trabalho, dá maior ênfase ao PDV que avalia o trabalho negativamente. $O$ escrevente retoma 0 PDV do segundo fragmento, mas não se solidariza com ele, refuta-o para apenas partir dele e por em cena um enunciador que traz consigo outro PDV, expresso no exemplo [98]:

[98]:

6 ○ § Já o trabalho do artista que geralmente é feito porque a pessoa gosta; tem o "dom"; o "talento" a dignifica uma vez esta esta [sic] se realizando mais espiritualmente (R198, grifos meus).

No exemplo [98], entra em cena um enunciador cujo PDV valoriza o trabalho de arte de tal modo, que assume o PDV do primeiro provérbio: o trabalho [de arte] dignifica o homem. O papel da adjetivação, na inserção desses enunciadores, mostra sua importância para a construção de PDVs e para a construção do PDVD, estabelecido no parágrafo conclusivo, exemplo [99]:

[99]:

$7^{\circ}$ § Portanto existem varios aspectos do trabalho. [...] faz se necessário que a sociedade não o imponha como necessidade para a sobrevivência do homem; Mas sim como uma função libertadora, [...], ser um verdadeiro artista $e$ assim encontrar sua satisfação pessoal e espiritual, sem ser prejudicado financeiramente (R198, grifos meus).

No início do parágrafo conclusivo, é retomado o PDVD da prova de redação: "há diferentes visões do trabalho". A inserção desse PDVD é uma preocupação do escrevente em mostrar não só sua concordância com a banca, assumindo esse PDV, mas é também uma tentativa de atender ao solicitado na instrução da prova. $\mathrm{Na}$ redação (R198), a argumentação é direcionada para o PDV que valoriza o trabalho, de modo geral, quando impõe, pelo caráter deôntico da modalização,"faz se necessário", e pela articulação com uma adjetivação forte, a dominância da valorização do trabalho e que este deve ser como o trabalho de arte: "uma função libertadora", para que o homem seja "um verdadeiro artista" e tenha "satisfação 
pessoal e espiritual". Nessas adjetivações há uma valoração positiva do trabalho, reforçada pelo uso axiológico de alguns termos, como "libertadora", "verdadeiro", "satisfação", "espiritual" que possuem uma carga avaliativo-positiva. Todos eles reforçam o caráter argumentativo da qualificação do trabalho e corroboram o PDVD, aquele que valoriza o trabalho e o compara com o trabalho de arte, isto é, aquele que liberta, que é verdadeiro e satisfaz pessoal e espiritualmente. Esse PDV reforça o discurso capitalista que, além de valorizar o trabalho pelo sustento que possibilita ao homem, é igualmente valorizado por trazer a dignidade para ele. Não está em jogo a exploração do trabalhador para gerar riquezas para aumentar ainda mais o capital que não está na mão do trabalhador, mas de uma elite capitalista.

Considerando as redações (R220) e (R198), vê-se que o PDVD, nessas redações, é construído a partir da inserção do Outro no discurso. De acordo com Rocha (1995, p. 169), "usar o provérbio é usar o discurso do Outro, é fazer-se falar pelo Outro". Se o uso do provérbio já expressava um caráter argumentativo, seu uso subvertido, como em (R198), confirma ainda mais esse caráter, porque vai mostrar que o escrevente é capaz de contrariar um discurso, um já-dito, já estabelecido pelo senso comum e veiculado pelo provérbio. Essa estratégia é fortemente determinada pelas condições de produção, por exemplo, respondendo ao manual de instrução do candidato, que exige a capacidade argumentativa e inventiva do candidato. Nesse sentido, o uso do provérbio e a sua transformação evidenciam o trabalho do escrevente com a linguagem e corresponde ao caráter responsivo-ativo do enunciado, reforçando seu caráter dialógico.

\section{b. A subversão do PDV do provérbio}

Esse mesmo provérbio é usado em outra redação, agora para qualificar o trabalho negativamente. Há, nesse caso, um embate de vozes introduzidas por enunciadores diferentes, com posicionamentos opostos:

[100]:

1 § Da subsistência as indústrias, o trabalho migrou da sobrevivência até um mecanismo de supremacia de classe, [...] é também claro o modo como a noção foi estereotipada e sistematizada.

2 § $§$ "O trabalho dignifica o homem" é um estereótipo usado 
para subverter o trabalho em prol do ideal burguês. [...] (R238, grifos meus).

Pode-se observar no exemplo [100], primeiro parágrafo, que a adjetivação qualifica a noção de trabalho e não 0 trabalho em si, numa referência metalinguística. Ele faz uso de uma adjetivação avaliativa que abre o modo como o escrevente vai construir um PDV no texto. Ele também mobiliza um saber específico de sua memória discursiva, mas fruto de seus letramentos, quando trata da transformação do trabalho do âmbito "da sobrevivência" para a referência a um "mecanismo de supremacia de classe", alegando ser essa transformação concordante com a "dialética marxista". A mobilização desse saber de autoridade mostra sua preocupação com o outro. Na sequência, entra em cena uma voz outra, por meio da introdução do provérbio, "o trabalho dignifica o homem". Nesse caso, o discurso veiculado nesse provérbio, não é o mesmo assumido pelo escrevente, como se pode perceber na definição dada pelo escrevente, ao qualificar o provérbio como um estereótipo a serviço do ideal burguês. Na sequência, quarto parágrafo, ele enfatiza essa qualificação, exemplo [101]:

[101]:

4 $§ O$ trabalho como se conhece hoje é tido como uma necessidade. [...] joga o homem em uma situação de caos em que não há emprego para todos [...] (R238, grifos meus).

A voz do provérbio não é a assumida pelo escrevente; pelo contrário, ele impõe um distanciamento dessa voz, marcado no texto pela adjetivação do próprio provérbio, que é qualificado, além de subversivo e a favor do ideal burguês, como necessário. Mas essa necessidade traz consigo uma "situação de caos", o desemprego. O movimento desse jogo enunciativo mostra que o escrevente mobiliza uma voz que não é a sua e com a qual ele não concorda, a do provérbio, para construir sua própria voz e mostrar seu posicionamento. Ao qualificar como "situação de caos" a que o trabalho joga para o homem, o escrevente dá sinais para o posicionamento que deseja assumir: acabar com o estereótipo de que o trabalho dignifica o homem, como pode ser percebido na adjetivação deôntica, no exemplo [102]:

[102]:

5o § Essa situação deixa claro que o trabalho sistemático, o emprego, não desaparecerá e que não será feito por máquinas, 
em sua totalidade, para que se tenha mais tempo livre. É necessário desconstruir o estereótipo do trabalho sistemático, para que haja melhoras [...] (R238, grifos meus).

O escrevente dialoga com os fragmentos da coletânea e, para isso, assume um PDV que é construído a partir da mobilização de saberes de autoridade, para validar seu discurso, como se pode notar na finalização do sexto parágrafo:

[103]:

6- $\S 0$ homem é criativo e capaz de se reinventar, [...] sempre estaremos realizando trabalho, $[\ldots]$ o trabalho árduo do artista, o suor do lavrador, a exploração do proletariado [...]. O trabalho [...] carregará para sempre essa noção de dor e arrependimento, fazendo jus à sua etimologia: o trabalho vem do latim, "tripalium", que significa um instrumento de tortura (R238, grifos meus).

No parágrafo conclusivo, aberto com uma adjetivação positiva do homem, se estabelece um movimento de posicionamentos distintos ora nivelando o trabalho de arte com demais tipos de trabalho, ora avaliando negativamente o trabalho como "dor e arrependimento", agora não mais com a adjetivação, mas com o uso de substantivos carregados de valores negativos. $O$ escrevente finaliza sua conclusão, mobilizando um saber de autoridade, ao abordar a etimologia da palavra trabalho. Constrói, com isso, uma imagem positiva de si mesmo, um escrevente que conhece a origem etimológica da palavra trabalho e assumindo o mesmo PDV do segundo fragmento: o trabalho não dignifica o homem, ele é dor e arrependimento.

Como se pode ver nos exemplos analisados da esfera popular, o escrevente mobiliza alguns saberes marcados, como o que traz o uso do provérbio. Esses saberes, tomados da (sua) memória discursiva, são também resultados de seus diferentes letramentos. $O$ escrevente mobiliza esses saberes, porque os julga como pertinentes para construir seu texto, em função dos discursos que eles veiculam. $O$ PDV construído a partir da mobilização desses saberes ressalta o caráter ideológico que eles carregam em seus discursos. Assim, a mobilização do saber popular, vista no uso dos provérbios, é um instrumento utilizado para a construção argumentativa do texto pelo escrevente, em virtude do próprio discurso que veicula e da representação de seu outro, ou, melhor ainda, o que esse discurso vai repercutir em seu outro. 
Por um lado, o escrevente constrói a imagem de um sujeito politizado, cujo discurso denuncia não a dignificação do homem pelo trabalho, mas a sua indignação com a dor e a exploração do trabalhador: "É necessário desconstruir o estereótipo do trabalho sistemático, para que haja melhoras" (trecho do quinto parágrafo de (R238).

Do outro, toma a palavra do outro para fazê-la sua, incorporando um tom imperativo do trabalhar para ser dignificado, fundada numa adjetivação deôntica, "é preciso", "é necessário". O uso do provérbio traz um saber de autoridade tanto no sentido do que ele enuncia como em seu caráter de repetição de um já-dito instituído. Segundo Fernandes (1979, p. 26), o provérbio "projeta, direta e imediatamente, as razões ou os juízos da pessoa em uma esfera indiscutível e irretorquível". Além disso, de acordo com o autor, o provérbio dita comportamentos valorizados socialmente como "ideais" e por isso, "concorrem, pelo menos para reiterar a lembrança de que determinadas maneiras de sentir, de pensar e de agir são consagradas socialmente, devendo ser respeitadas dentro do possível" (op. cit., p.27). Talvez, por isso, na totalidade do corpus, o uso que prevalece do provérbio é o do tom dignificador do trabalho (18\%). Mas vale citar uma subversão, também trabalhada pelo escrevente, na estrutura e no conteúdo do provérbio:

[104]:

O dito popular é que o trabalho enobrece, mas há os que dizem que ele embrutece. (R243).

Da mesma forma que na outra subversão, há um trabalho do escrevente com a representação da escrita e do gênero provérbio: uma estrutura curta, com simetria e rima. O escrevente parafraseia o provérbio fonte em sua estrutura, subvertendo seu conteúdo proposicional, contribuindo para a construção de outros sentidos.

Há também, no corpus, a presença de outros provérbios ${ }^{69}$, slogans e frases prontas, bem como as suas paráfrases.

\footnotetext{
${ }^{69}$ Há provérbios que podem ser marcados na esfera religiosa, mas foram mencionados somente neste item. Há outros, porém, que foram mencionados na esfera religiosa, por manterem um diálogo maior com ela. Vale ressaltar que o provérbio "o trabalho dignifica o homem", analisado na esfera popular, também está atrelado à esfera religiosa, pois o homem, segundo o mito bíblico, pecou no paraíso e por isso deixou de ser digno. Terá de trabalhar com o suor do rosto para pagar o pão do seu sustento e restituir sua dignidade de ser humano.
} 


\section{Os saberes e a esfera religiosa}

A esfera religiosa merece destaque em virtude da relação dos discursos que nela circulam com o tema trabalho. $O$ discurso religioso tem um caráter ambíguo em que ora o trabalho é valorizado, ora é depreciado. Além disso, a igreja, vista como um aparelho ideológico do estado (ALTHUSSER, 1980), sempre apoiou o sistema capitalista e cresceu juntamente com ele. Em oposição ao discurso religiosocapitalista-elitista, surgiu a teologia da libertação que, na figura de alguns religiosos que ousaram se opor a essa igreja, manifestava-se a favor dos explorados e lutavam para acabar com a desigualdade social. $\mathrm{Na}$ totalidade do corpus, o discurso predominante é o da denúncia ao trabalho exploração, que tem por trás uma única verdade, que é a verdade da ideologia capitalista, de que se trabalha para ter dignidade. Nas redações, está presente um discurso, afirmando que trabalho é castigo, sofrimento e todos devem "suar o rosto para ter o sustento". O que está em jogo é a ética do trabalho sob a visão da religião e do capitalismo.

O provérbio recorrente nessa esfera e selecionado para análise é fundado no mito bíblico relatado no livro de gênesis: "comerás o pão com o suor do seu rosto". Nesse mito, o trabalho é visto como castigo de Deus à humanidade pecadora. Ao contrário dos exemplos dos dois outros provérbios já analisados, o uso deste provérbio está vinculado à qualificação negativa do trabalho, que agora, ao invés de dignificar o homem, é visto, por meio desse mito bíblico, como maldição lançada sobre a humanidade e, nessa direção, o trabalho é sofrimento. Entretanto, ainda assim, há espaço para a valorização do trabalho de arte, como mostrarei no parágrafo conclusivo. O exemplo [105] mostra como todo o primeiro parágrafo foi construído a partir da mobilização desse saber mítico:

[105]:

10 § No Gênesis, o primeiro livro da bíblia, encontramos a famosa passagem na qual Adão e Eva [...] Deus, irado por conta dos pecados cometidos [...] lança uma maldição sobre a humanidade [...] as mulheres teriam que sofrer para conceber seus descendentes, enquanto os homens teriam que ganhar a vida com o suor do seu próprio rosto. Trabalhando (R201). 
A referência ao Gênesis, no primeiro parágrafo, é um saber que já existe antes da produção da redação e o escrevente o mobilizou e o transformou em texto a fim de construir um PDV com argumentos baseados em seu conhecimento de mundo. O escrevente defende, pois, a tese de que trabalho é sofrimento, sob dois argumentos: maldição e expiação. A adjetivação é bastante relevante no exemplo [105]. A referência a Adão e Eva é feita com a anteposição de um adjetivo avaliativo, "famosa passagem", causando um efeito de sentido de longevidade e permanência de um texto tido como conhecido não só do escrevente, mas principalmente de seu leitor. Na sequência, a adjetivação de Deus mostra-se pertinente, no sentido de mostrar um estado emocional - irado - que o levou a lançar tal maldição contra a humanidade. A adjetivação finalizando o primeiro parágrafo, "trabalhando", também mostra como o escrevente enfatiza essa maldição. O escrevente assume o PDV introduzido pelo enunciador, o livro de "gênesis", que assegura ser o trabalho uma maldição.

A partir do segundo parágrafo, o escrevente mobiliza outros saberes, ainda da esfera religiosa. Parte novamente de um saber motivado por um fato mítico da cultura judaico-cristã - "a maldição de Adão" -, mas busca a sustentação dos argumentos para construir seu PDV em seu conhecimento de mundo sobre diferentes religiões e seus seguidores:

[106]:

2o § Ao longo dos milênios a maldição de Adão tem acompanhado os homens sejam estes cristãos, mulçumanos, budistas ou ateus. Assim como também as mulheres [...] O esforço da humanidade para prover seu próprio sustento [...], se tornar cada vez mais árduo a medida que mais riquezas são geradas (R201, grifos meus).

Em [106], o escrevente vale-se de diferentes adjetivos que qualificam os homens de diferentes opções religiosas. Nesse momento, o escrevente utiliza como estratégia argumentativa a enumeração desses adjetivos para manter o mesmo campo semântico contemplado pela tese apresentada na introdução, como forma de coerência temática. Ainda nesse parágrafo, é introduzido outro enunciador cujo PDV se apoia na luta das mulheres. O escrevente desliza da progressão temática que vinha construindo na direção da referência às mulheres, ao mencionar a entrada delas no mercado de trabalho, construindo de si uma imagem positiva. Ao finalizar o 
parágrafo, o escrevente faz uso da adjetivação axiológica e intensificada, para mostrar mais efetivamente o PDV que está construindo, com a qualificação negativa do trabalho.

Apesar de o seu PDV ser fundamentado num fato mítico de domínio público (pelo menos entre a cultura judaico-cristã): "[...] livro da bíblia [...] a famosa passagem [...] Adão e Eva são expulsos do paraíso" (trecho de R201, grifo meu), está distante de um quadro histórico que lhe dê sustentação. Nesse sentido, busca, no contra-argumento, essa historicidade ausente até então. Entra em cena, então, um enunciador genérico, "muitos tem começado a se questionar", cujo PDV está voltado para as informações da atualidade e um enunciador que prega o tempo livre: [107]:

$3^{\circ} \S[\ldots]$ entretanto, muitos tem comecado a se questionar [...] pregarem a importância do tempo livre [...] Alguns países como a França já começam a propor uma redução da jornada de trabalho padrão de quarenta horas semanais para trinta e cinco horas [...]. Livros como "O ócio criativo, do italiano Domenico De Masi, [...] ao pregarem a importância do tempo livre [...] (R201, grifos meus).

O escrevente constrói a imagem de um sujeito bem informado e de um bom leitor. Com a construção dessa imagem, direciona a construção do PDV para seu destinatário. Conclui seu texto, reafirmando, no $4^{\circ}$ e último parágrafo, o PDV que vinha construindo, afirmando-o num tom de clareza:

[108]:

4 § [...] fica cada vez mais claro que a maneira como se organiza o trabalho em nossa sociedade [...] como na Bíblia, muito mais perto de uma maldição [...]. Jornadas de trabalho longas demais [...] abusos psicológicos [...] esforço [...] frustrado [...] atormentam o dia das pessoas que trabalham (R201, grifos meus).

Nesse parágrafo, o PDV defendido é o de que o trabalho é maldição. PDV compartilhado com o enunciador do primeiro parágrafo, "gênesis". O escrevente, no uso de adjetivações, reafirma sua tese e fortalece seus argumentos, usando como estratégia argumentativa a exemplificação do motivo pelo qual o trabalho é maldição. Apesar de diferentes argumentos e do percurso traçado pelo escrevente na organização do seu texto, ele permanece no senso comum, em que a noção de trabalho é entendida como sofrimento. O escrevente aposta na "inércia da vida 
social" (PERELMAN \& OLBRECHTS-TYTECA, 2005, p. 120) ao mostrar que a noção de trabalho enquanto sofrimento permanece até hoje, uma vez que todos os seus argumentos vão à direção da evidência de que, desde o princípio dos tempos, nada mudou. Ainda no parágrafo conclusivo, em seu início, há outro deslizamento do escrevente, ao qualificar o trabalho de arte em seu texto:

[109]:

4 $§$ Não resta dúvida de que o trabalho tem sua importância na vida das pessoas. Para muitos, como por exemplo os artistas, é o meio de realização pessoal por excelência [...] (R201, grifos meus).

Num tom de certeza, "não resta dúvida", muda totalmente o percurso que vinha construindo, e introduz um enunciador genérico, "Para muitos", para avaliar positivamente o trabalho de arte. Essa avaliação está centrada no uso de substantivos carregados de valores: "importância", "realização", "excelência". Esse modo de qualificação demonstra que a enunciação demanda efeitos na organização textual da redação, já que os modos de qualificação decorrem das representações que o escrevente faz de seu outro/Outro e do próprio ato de escrever, estes mediados pelo modo como lê e interpreta os textos da prova de redação. Para atender ao que foi solicitado na instrução, "relacionar os três textos", e como forma de não deixar o terceiro fragmento de fora dessa relação, um enunciador é bruscamente introduzido, para firmar um PDV na direção de seu destinatário, construído abruptamente segundo as representações de seu outro, a universidade como instituição que o avalia. Ao introduzir esse PDV, o escrevente quer mostrar uma imagem positiva de si, como alguém que, apesar de considerar o trabalho castigo, maldição, valoriza o trabalho de arte, como supostamente, segundo suas representações, a universidade também valoriza, ao escolher apenas um tipo de trabalho, o de arte, para compor a prova de redação.

Esse mesmo mito bíblico também está presente em outras redações, para enfatizar não só a exploração do trabalhador - qualificando negativamente o trabalho - como também a necessidade de sustento por meio do trabalho e, neste caso, o trabalho é valorizado positivamente. No que se refere à cultura judaicocristã, os saberes que, dialogando com o tema "o trabalho", mostram uma relação de culpabilização da religião pelos males do mundo, vista nas redações na figura de Calvino e/ou Lutero e da reforma protestante, exemplo [110 ]: 
[110]:

A criação do dinheiro como recompensa pela realização deste ideal capitalista - também é parte importante da história e influencia religiões (como o calvinismo, que exaltava o trabalho e o ganho de bens materiais) e mentes (R133).

Há, ainda, aqueles saberes relacionados às religiões não cristãs, como o budismo, exemplo [111], que pode circular também na esfera midiática. Aliás, nesta esfera, pelo próprio fato de ser meio de divulgação, pode abarcar diferentes saberes:

[111]:

Os monges budistas costumam construir mandalas imensas no chão dos templos, feitas com inúmeros grãos de areia de diversas cores, formando belos desenhos que auxiliam a concentração e meditação. É um trabalho árduo de muita dedicação e paciência (R121).

\section{E. Os saberes e a esfera midiática}

Outro modo de depreender o PDVD é por meio da mobilização de saberes relacionados a fatos da atualidade e nos quais o escrevente busca força argumentativa para fortalecer sua argumentação e construir um PDV. Esses saberes são mobilizados da esfera midiática. O PDVD é construído a partir de discursos que circulam nessa esfera e das representações do escrevente. O exemplo [112] mostra que o escrevente parte do PDV do segundo fragmento para construir outro PDV, oposto ao da coletânea. Para isso, o enunciador introduz, no primeiro parágrafo, o mesmo PDV da coletânea, retoma o já-enunciado no segundo fragmento, assumindo o mesmo posicionamento:

[112]:

O trabalho e a sociedade

$1^{\circ} \S$ Em nossa sociedade, o trabalho sempre foi considerado uma fonte de evolução e progresso para o homem, [...]. Contudo, muitos indivíduos tornam-se excessivamente ocupados com sua profissão e privam-se do convívio social, o que os prejudica, enquanto outros tornam-se excluídos por não terem uma profissão. [...] tanto o excesso quanto sua falta são altamente prejudiciais (R006, grifos meus). 
O escrevente adota como estratégia argumentativa contrastar, no primeiro parágrafo, o excesso e a falta de trabalho - mesmo PDV do segundo fragmento -, apresentados como tese. A partir dessa tese, constrói certa hierarquização no jogo entre essas polaridades - excesso e falta -, por meio da adjetivação, denunciando que ambas "são altamente prejudiciais". O escrevente solidariza-se com um PDV da coletânea e o enfatiza por meio da adjetivação. Ao final do primeiro parágrafo, aponta para a direção que vai seguir: "tanto o excesso quanto sua falta são altamente prejudiciais". No segundo parágrafo, mobiliza saberes da esfera midiática, para fortalecer ainda mais esse PDV:

[113]:

2ㅇ Um exemplo típico dessa situação é a ilha de Manhattan, nos Estados Unidos, onde podem-se ver altos executivos dos grandes escritórios internacionais trabalhando muitas horas por dia, convivendo com os desempregados que ficam pelas ruas na eterna esperança de obter um emprego, [...] (R006).

O escrevente busca, na mobilização desses saberes, informações que ele julga de autoridade, para validar e valorizar o seu dizer. Depois de denunciar a desigualdade gerada pelo trabalho também nos Estados Unidos, qualifica o trabalho com uma adjetivação modalizada e axiológica, lançando o seu PDV: "Esse contraste nos leva a crer que o trabalho é algo extremamente essencial á vida do homem, mas que deve ser melhor distribuído, [...]" (R006, grifos meus). O escrevente assume um PDV fornecido pela coletânea, para, a partir dele, construir o seu. Entretanto ele desliza para outro PDV introduzido no terceiro parágrafo, sem aparente ligação com o que ele vinha construindo, pois justifica a melhor distribuição de oportunidades de trabalho com o controle de natalidade que, segundo ele, traria mais equilíbrio ao problema da falta e excesso de trabalho. Trata-se de um saber mobilizado da esfera midiática, mas que pode também estar relacionado com a esfera escolar:

[114]:

3o § Talvez um controle de natalidade feito com colaboração do governo ajudasse na melhor distribuição das oportunidades de emprego, pois a taxa de nascimentos não acompanha a de crescimento do trabalho, criando um desequilíbrio (R006, grifos meus). 
O escrevente põe em cena um enunciador, cujo PDV revela um discurso extremamente conservador, que passa por cima de decisões individuais da mulher de ter ou não filhos, passando esse poder para as mãos do governo, para controle do nível de emprego/desemprego. Há, nesse sentido, um embate de PDVs, em que o escrevente procura se firmar para construir um PDVD, tentando ir por um caminho, posicionando-se a favor de um equilíbrio social para o problema do desemprego, mas desliza para outro que foge a seu controle. Trata-se, nesse sentido, de um PDV que tenta se sobrepor, mas isso não acontece na sequência do enunciado. No quarto e último parágrafo, volta à cena o mesmo enunciador cujo PDV solicita o equilíbrio pela diminuição da exploração:

[115]:

$4^{\circ} \S$ O que deve acontecer é uma readaptação social para que a maioria dos indivíduos tenha acesso a um trabalho, mas na medida em que não seja em excesso, o que já provou ser prejudicial (R006).

Desse modo, o escrevente solidariza-se com o PDV do segundo fragmento, mas não o assume para si, porque constrói seu PDV em função de suas representações, isto é, das imagens de si e de seu outro. O escrevente mostra isso ao direcionar argumentativamente seu texto, mobilizando esses saberes de autoridade segundo suas representações, para mostrar a imagem não só de um sujeito bem informado, mas também de alguém que aponta a solução para o desequilíbrio nas oportunidades de trabalho. Finaliza sua redação num tom de certeza, valorizando o trabalho positivamente:

[116]:

4ㅇ § 0 trabalho é parte essencial de nossas vidas e devemse criar oportunidades para que todos possam usufruí-lo (R006, grifos meus).

O tom deôntico também aparece, e não só no final, mas no todo da redação, "deve ser melhor distribuído", "não pode vir em excesso", "não deve faltar", "devemse criar oportunidades", para fortalecer ainda mais seu posicionamento. 0 escrevente se solidarizou com um PDV da coletânea, trabalho é exploração, mas construiu outro, pautado da obrigatoriedade de mudança para sua melhor distribuição. Esse PDV também ganhou força na excessiva modalização da importância do trabalho: "o trabalho é algo extremamente essencial á vida do 
homem" (trecho do segundo parágrafo), "O trabalho é parte essencial de nossas vidas" (trecho do quarto parágrafo), como também nas anteposições dos adjetivos dimensionais, no segundo parágrafo: "altos executivos", "grandes escritórios internacionais", "eterna esperança", todas contribuindo para a construção de um efeito de sobreposição, constituindo, assim, o PDVD.

A mobilização de saberes da mídia também foi marcada sob outras representações, como em [117], pela enumeração de fatos contemporâneos ligados à crise socioeconômica, que denuncia a situação atual da necessidade do trabalho para a sobrevivência:

[117]:

$1^{\circ} \S$ Modernamente, no século em que nos encontramos, o trabalho é uma palavra intimamente ligada ao dia-a-dia das pessoas. [...].

2 § Mesmo sem pensar que a economia de um país, ou outros fatores como corrupção, desvios de verbas, crises e diplomacia, podem mudar diretamente o rumo de um país, ainda assim você precisa trabalhar ou de alguém que trabalhe para te sustentar. [...] (R178, grifos meus).

A mobilização de saberes da mídia traz para o enunciado os acontecimentos contemporâneos ao escrevente, que ele seleciona, dentre outros, porque considera pertinente para reforçar a direção argumentativa da construção de PDVs.

\section{F. Os saberes e a esfera histórica}

Esta esfera está organizada em função de um saber histórico, mobilizado pelo escrevente apoiado em fatos e acontecimentos ligados, de certa forma, à questão socioeconômica, mas que traz consigo uma visão histórica do trabalho construída com base, principalmente, nos conteúdos escolares. Digo principalmente por suposição, uma vez que não é possível delimitar a fonte exata da mobilização dos saberes. Nas redações, esse saber manifesta-se de diferentes maneiras, por exemplo, pela escolha prática como forma de estruturação do texto em que, na introdução, é tratado um passado remoto; no desenvolvimento algum ponto posterior na história do trabalho, finalizando, na conclusão, com o tempo presente. Em cada um dessas temporalidades o trabalho é caracterizado numa relação dialógica com o textos dos fragmentos da coletânea, como se pode observar no exemplo [118]: 
[118]:

$\mathrm{Na}$ era do trabalho

1ㅇ § $\mathrm{Na}$ era pré-histórica [...]. As formas de trabalho do homem pré-histórico eram limitadas à procura de alimentação para subsistência de seu clã.

2o § Na Idade média houve uma grande ampliação nas modalidades de trabalho, havendo também um aprimoramento e estreitamento das relações trabalhistas, porém este continuou reservado apenas às classes pobres, [...].

3 § Foi com o surgimento do protestantismo [...] surgiu a idéia de que o trabalho é uma dádiva divina e de que somente através dele a riqueza e estabilidade econômica poderão ser alcançadas. [...] que para a população pobre funcionam como um estímulo, mas na realidade não deixam de ser uma simples e mal explicada justificativa para as desigualdades sociais, segundo demonstram sociólogos como Marx Weber e Emile Durkheim, [...] além de tantos outros.

$4^{\circ}$ § A sociedade moderna vive um dilema pois o capitalismo exige altos lucros, [...] em contrapartida, a população se dilacera por uma vaga de emprego (R014, grifos meus).

No primeiro parágrafo, a qualificação do trabalho se dá por sua caracterização, em função da temporalidade remota: "As formas de trabalho do homem pré-histórico eram limitadas à procura de alimentação", fazendo remissão à origem do trabalho. Nos segundo e terceiro parágrafos, essa caracterização se dá na referência a um tempo intermediário: "Na ldade média" e a um fato histórico, "o surgimento do protestantismo", ambos remetendo aos aspectos da exploração do trabalho. No parágrafo conclusivo, o trabalho é caracterizado em função do tempo presente, "A sociedade moderna".

No que se refere à construção de PDVs, nessa redação, o escrevente se solidariza com o PDV do segundo fragmento, assumindo esse mesmo PDV, como pode ser constatado no parágrafo conclusivo, ao justificar o desemprego em razão da mecanização do trabalho: "o capitalismo exige altos lucros, o que justifica a crescente mecanização da mão de obra, em contrapartida, a população se dilacera por uma vaga de emprego". Para chegar a esse PDV, o escrevente mobilizou saberes históricos, por meio da encenação de dois PDVs: um, da filosofia protestante, que considera o trabalho uma "dádiva divina", para justificar a exploração do trabalhador e; outro, que se opõe a esse e que denuncia a exploração pelo trabalho, utilizando para isso, a polifonia de autoridade: "segundo demonstram 
sociólogos como Marx Weber e Emile Durkheim". Ao citar personagens da história, tidos, pelo escrevente, como presumidamente conhecidos de seu interlocutor, constrói uma boa imagem de si, a de um sujeito que domina conhecimentos da história, não vinculados somente à escola básica. O escrevente joga com esses PDVs para, a partir deles, construir o PDVD, que se mostra no parágrafo conclusivo. Entretanto, esse PDV não é o seu, mas aquele com o qual ele se solidarizou, ou seja, o PDV do segundo fragmento. O escrevente, por meio da mobilização de saberes, justifica essa solidarização, para corroborar esse PDV, o escrevente se apoia na adjetivação usada num PDV, o do "protestantismo" que vê o trabalho como "dádiva divina", para contrapor-se a ele, com outra adjetivação tomada de outros PDVs, o de "Marx [sic] Weber e o de Emile Durkheim": "mas na realidade "não deixam de ser uma simples e mal explicada justificativa" para as desigualdades sociais". Desse modo, o PDVD foi construído na correlação com outros PDVs, não se constituindo como o PDV do escrevente, mas na solidarização com PDVs da coletânea.

Uma subesfera diretamente relacionada com a esfera histórica é a do trabalho, já comentada no que se refere à representação social do trabalho como um fator organizador do desenvolvimento do tema solicitado pelo exame.

Os saberes mobilizados nessa subesfera tratam das relações de trabalho, principalmente no que se refere à defesa dos direitos do trabalhador. Num primeiro momento, denuncia-se uma situação de exploração, para, ao final, tentar dar uma solução para o destino do trabalho. Em [119], já no título da redação, o escrevente, por meio de um enunciador, põe em cena um discurso outro em seu texto, parafraseando um provérbio:

[119]:

Diga-me onde trabalhas, e te direi quem és

10 § [apresenta, em forma de narrativa, o início/fim de um dia de trabalho na cidade de São Paulo]. Procuram estas pessoas subsistência? Satisfação pessoal? Ambos, ou algo mais?

2o \& [...]. Enquanto isso, pobres daqueles que sequer chegarão a encarregados: [...], não obstante seja fácil encontrar, numa andança por Nova lorque, grande meca do consumismo, dezenas de mendigos brandindo cartazes com a inscrição "will work for food" - almejando sequer um salário, contentam-se em [...]: comer (R081, grifos meus). 
No primeiro parágrafo, apresenta, em uma narrativa, o início e o fim de um turno de trabalho na cidade de São Paulo, finalizando o parágrafo, com perguntas retóricas, sobre o que procurariam esses trabalhadores. No segundo parágrafo, mobilizando saberes da mídia sobre o trabalho em excesso e o desemprego, compara informações do Brasil e dos E.U.A. Para enfatizar esse PDV, utiliza-se de uma adjetivação axiológica. $\mathrm{O}$ terceiro parágrafo encena um PDV, por meio de uma adjetivação superlativa, que trata da problemática das relações de trabalho na "Capital Paulista", mobilizando também saberes da esfera jurídica, mostrando-se conhecedor dessa problemática:

[120]:

3o § Perigosíssima, aliás, a premissa de que aquele que precisa trabalhar o fará em qualquer condição. [...], piora crescente nas condições de trabalho daqueles que precisam colocar comida na mesa: prova disso é que, nas setenta e nove varas do trabalho da Capital Paulista entram, em média, duzentos processos por mês. [...] (R081, grifos meus).

No parágrafo conclusivo, o escrevente responde ao primeiro fragmento, afirmando que o trabalho não vai acabar. Na sequência, ele mobiliza saberes de autoridade, em função da imagem que está construindo de si, para seu outro, a de alguém que domina várias esferas do saber, desde a história até a jurídica. Essas mobilizações também mostram a replica ao que ele supõe ser exigido de um bom candidato:

[121]:

4o § [...]. Considerando tal cenário, parece difícil que o trabalho venha a desaparecer e, como queria Marx, que o capitalismo, vítima de suas próprias contradições, ceda lugar ao socialismo e, após, ao comunismo, onde se trabalha pelo bem comum. [...], é certo que o ser humano só será capaz de trabalhar por qualquer "bem comum" quando conseguir resolver os paradoxos que lhe são impostos por suas relações com o trabalho (R081, grifos meus).

Em R081, o PDV que prevalece é aquele em que o escrevente se solidariza do segundo fragmento: o de que vai permanecer a exploração do trabalhador. Num tom de certeza, afirma que o fim da exploração é remota, uma vez que depende da resolução dos paradoxos das relações de trabalho. 


\section{G. Os saberes e a esfera do mercado cultural}

Procurei sintetizar nessa esfera o que depreendi das redações como saberes que circulam na esfera artística, englobando, por exemplo, a música, o cinema, a escultura, a poesia e também aqueles mais relacionados a um saber acadêmico, como a filosofia, por exemplo. Desses saberes, pode-se depreender as representações sociais do trabalho e, especificamente, do trabalho de arte. De modo geral, são saberes mobilizados para ratificar o PDV em que se valoriza o trabalho de arte:

[122 ]:

A poesia, a música, a arte em geral, pode ser considerada uma forma sublime de trabalho que de uma maneira ou de outra atinge todos à sua volta. Os grandes gênios artísticos fazem com que, o que para muitos pode se tornar cansativo e entediante, algo que seja extremamente precioso aos olhos e ouvidos (R067).

Há, também, aqueles, em menor número, em que se mobiliza o saber do mercado cultural para qualificar o trabalho de arte negativamente:

[123]:

Atualmente, [os artistas] são pouco remunerados, pouco apreciados e pouco conhecidos. Os que ficam famosos, ficam muito famosos, e vão morar no exterior. Walter Salles, cineasta brasileiro, hoje vive em Hollywood e trabalha com atores mundialmente admirados. A música, única arte que ainda faz o Brasil estremecer, vem decaindo desde o "Bonde do tigrão". Tom Jobim e Chico Buarque viraram lembranças na vitrola (R209).

Há, também, a mobilização do saber do mercado cultural em que entra para denunciar a exploração do trabalhador, como o filme "Tempos Modernos", de Charles Chaplin:

[124]:

O correto é conciliarmos nossa vida pessoal com nosso trabalho e não permitir que sejamos escravos deste (como ocorria com Charlie Chaplin no filme "Tempos Modernos"), mesmo que com todas essas mudanças isso seja difícil (R145).

\section{H. Os saberes e a esfera da saúde}


O trabalho é visto, nessa esfera, como o causador de vários problemas de saúde do trabalhador, motivados pela falta, mas principalmente pelo excesso de trabalho e o pouco tempo para lazer. No exemplo [125], fica bem nítido o posicionamento do escrevente e as diferentes representações sociais do trabalho e do trabalho de arte:

[125]:

As facetas do trabalho

$1^{\circ} \S O$ trabalho tem se tornado cada vez mais essencial na vida das pessoas. [...].

20 § Com o passar do tempo, o trabalho foi se moldando de acordo com acontecimentos históricos, [...].

3o § Devido à necessidade do saldo positivo, pessoas trabalham mais, o que faz com que sua saúde seja prejudicada, devido ao estresse, e também causa muitas vezes a desestruturação da família. [...].

4 § É crescente o número de crianças e adultos com [...] depressão, estresse,síndrome do pânico, entre outros, decorrentes da correria da vida cotidiana, que rouba o tempo para o lazer e descanso.

50 § Uma alternativa para a diminuição dessa carga de descontrole emocional é trabalhar com artes. [...]. Além de ser um processo de criatividade, auto-conhecimento e imaginação, ajuda a fugir um pouco da cruel realidade que nos faz deixar de contemplar as coisas mais simples e sutis da vida, talvez as mais importantes (R266).

Como se pode notar, no exemplo [125], o escrevente, ao afirmar que o trabalho é essencial para as pessoas, dialoga principalmente com o segundo fragmento, solidarizando-se com o PDV dele: o excesso e a falta de trabalho. O escrevente afirma, no terceiro parágrafo, que as consequências disso são os danos à saúde. A representação social do trabalho, construída na mobilização de saberes, é a de que o trabalho é prejudicial à saúde. E, para se contrapor a esse trabalho, o escrevente põe em cena um enunciador que qualifica positivamente o trabalho de arte, elegendo-o como o salvador para curar os danos causados pelo trabalho em excesso. No parágrafo conclusivo, o escrevente enfatiza ainda mais essa representação social do trabalho, por meio de uma adjetivação axiológica, "cruel realidade". Finaliza seu texto, privilegiando o trabalho de arte, com uma adjetivação intensificada, porque, por meio dele, pode-se contemplar as coisas "mais importantes" da vida. Desse modo, prevalece o PDVD que valoriza o trabalho de arte. 
Em outro texto, R105, a mobilização de saberes da esfera da saúde é um recurso usado para enfatizar a recusa ao PDV do segundo fragmento, mas, nesse, não há a valorização do trabalho de arte, que recebe uma crítica pelo modo como é qualificado. A mobilização de saberes de diferentes esferas se volta para justificativar o PDV que está sendo construído. O escrevente retoma o PDV do segundo fragmento, introduzido por um enunciador genérico: "Alguém disse", no primeiro parágrafo, e, nos parágrafos seguintes, estabelece um diálogo de aproximação com seu interlocutor, pelo modo como os inicia e direciona sua argumentação, isto é, enfatizando o PDV que assume, por meio da adjetivação axiológica.

[126]:

1 $\S$ Alquém disse que o correto é trabalhar para viver. No entanto, o que se passa é que vive-se para trabalhar. [...].

2 § Enlouquecedor, talvez essa palavra defina esse sistema escravocrata ao qual fomos condicionados. Escravocrata porque a divisão de lucros é injusta: enquanto o trabalhador braçal é agraciado com um salário miserável, o "cérebro" abocanha algo cerca de quinze vezes mais que a massa.

3ㅇ Esta tudo errado! Tudo mal dividido!

4ㅇ § É necessário levar em consideração que a dinâmica mundial, não mais comporta um sistema grego de trabalhar, [...]. Não é saudável que deixemos caixas-de-bancos; secretárias; analistas-de-sistema serem acometidos pela L.E.R (lesão por esforço repetitivo), é terrível para o empregado e ruim para o empregador. [...] (R105).

Vê-se que há um trabalho do escrevente com a linguagem. Sua indignação e recusa ao PDV do segundo fragmento é contundente e posta no terceiro parágrafo, com forte entonação expressiva dada pelo uso da exclamação articulada com a adjetivação avaliativa e axiológica. Esse PDV já havia sido enunciado no parágrafo anterior, por meio da dicotômica adjetivação que diferencia e qualifica o trabalhador braçal e o intelectual, este qualificado pejorativamente como "o 'cérebro", isto é, a cabeça pensante. O trabalho do escrevente é mais evidente na paráfrase dos slogans: "Não é saudável que"; "é terrível para o empregado e ruim para o empregador", que realça o jogo enunciativo da adjetivação construída ora com a negação ora com a afirmação. No exemplo [126], o PDVD foi construído por meio da adjetivação, evidenciado a recusa ao PDV do segundo fragmento, pelo modo como se utilizou das adjetivações. 


\section{CAPÍTULO 5}

\section{RECOLHA E INTERPRETAÇÃO DOS RESULTADOS}

Neste capítulo, procuro recolher e interpretar os resultados obtidos da análise. Nos itens (5.1) e (5.2), faço a recolha e a interpretação dos resultados obtidos sobre a construção do PDVD e sua relação, por um lado, com a coletânea e com a instrução fornecidas na prova (Capítulo 3) e, por outro lado, com as representações sociais que passam a atuar a partir da leitura da coletânea (Capítulo 4). No item (5.3), apresento a relação dialógica entre a construção do PDVD e os PDV depreendidos pelo escrevente. Finalizo o capítulo, buscando sintetizar o modo pelo qual se constitui a construção do PDVD na redação de vestibular (5.4).

\subsection{Classificação e interpretação dos resultados relacionados à ordem dos textos da coletânea}

Uma nota prévia: na leitura das tabelas que serão apresentadas neste capítulo, serão privilegiados alguns dados que considero como os mais importantes, não sendo, portanto, exaustiva a interpretação de cada uma delas.

Da análise dos exemplos constantes no capítulo 3, isto é, do diálogo do escrevente com a coletânea/instrução, constatou-se um modo bastante recorrente de organizar o texto: a partir da ordem dos textos da coletânea tomada como forma de estruturação do texto do escrevente. Como era de esperar numa situação de avaliação, houve tentativas de resposta aos enunciados da prova de redação, que foram vistas como réplicas e fundamentaram o jogo dialógico marcado explicitamente nesses modos de organizar o texto.

$\mathrm{Na}$ totalidade do corpus, a estruturação do texto do vestibulando com base na ordem dos textos da coletânea está presente em $51,1 \%$ das redações. A Tabela 2, além de apresentar os resultados obtidos quanto à reprodução da ordem dos textos dados na coletânea na estruturação do texto dos vestibulandos, dá indicações de outras ordens que se destacam pela baixa ou alta frequência: 
Tabela 2: Ordem de apresentação dos textos na coletânea e estruturação do texto do vestibulando

\begin{tabular}{|c|c|c|c|c|}
\hline \multirow{2}{*}{$\begin{array}{l}\text { MESMA ORDEM } \\
\text { DA COLETÂNEA } \\
\text { (T1, T2, T3) } \\
\text { ou } \\
\text { (T1, T2, T3 } \\
+ \\
\text { conclusão) }\end{array}$} & \multicolumn{3}{|c|}{$\begin{array}{c}\text { ORDENS DIFERENTES DA ORDEM COLETÂNEA } \\
\text { QUE SE DESTACAM } \\
\text { POR BAIXA OU ALTA FREQUÊNCIA }\end{array}$} & \multirow[t]{2}{*}{ TOTAL } \\
\hline & $\begin{array}{l}\text { VARIADAS } \\
\text { ORDENS } \\
\text { DIFERENTES } \\
\text { DA ORDEM } \\
\text { DA } \\
\text { COLETÂNEA }\end{array}$ & $\begin{array}{c}\text { ORDEM } \\
\text { DIFERENTE } \\
\text { CENTRADA NO } \\
\text { SEGUNDO TEXTO }\end{array}$ & $\begin{array}{l}\text { ORDEM } \\
\text { INVERTIDA } \\
\text { (T3, T2, T1) }\end{array}$ & \\
\hline 138 & 106 & 25 & 01 & 270 \\
\hline $51,1 \%$ & $39,2 \%$ & $9,3 \%$ & $0,4 \%$ & $100 \%$ \\
\hline \multicolumn{5}{|c|}{ T O T A L I Z A Ç Ã O } \\
\hline 138 & \multicolumn{3}{|c|}{132} & 270 \\
\hline $51,1 \%$ & \multicolumn{3}{|c|}{$48,9 \%$} & $100 \%$ \\
\hline
\end{tabular}

A dominância da manutenção da ordem de apresentação dos textos da coletânea na estruturação do texto dos escreventes evidencia o vínculo do seu modo de escrever com o seu modo de ler e interpretar os textos fornecidos pela prova.

O escrevente constrói PDVs voltados para o seu destinatário, no sentido de tomar esses textos como perguntas a serem respondidas para ele. Está em jogo a tentativa de cumprimento de uma tarefa, vista como tarefa escolar pelo escrevente, a de utilizar os textos da coletânea e mostrar essa utilização em seu texto. Desse modo, a leitura da disposição semiótica (espacial) dos textos da coletânea é traduzida pelo escrevente não só como imposição de abordagem de cada um dos textos, mas também como reprodução na mesma ordem. Portanto, a literalidade na reprodução daquela leitura é o que caracteriza o modo como o escrevente encara a solicitação: não como uma proposta de ler e dissertar sobre um certo tema, mas como simples solicitação de cumprimento de uma tarefa.

Dentre as outras ordens que se destacam pela baixa ou alta frequência, merecem uma observação particularizada as construções em que prevalece o 
diálogo exclusivo com o segundo fragmento, portanto sem marcas explícitas de diálogo com o primeiro ou com o terceiro fragmentos. Contando $9,3 \%$ de ocorrências, essa relativamente baixa incidência de diálogo com apenas um texto da coletânea, comparada aos outros índices em que o escrevente relaciona os três textos da coletânea - na mesma ordem, em ordem diferente ou invertida que, juntas, totalizam 90,7\% de ocorrências - reforça que o PDV construído no diálogo com a coletânea é o que o escrevente atribui ao destinatário, prevalecendo a voz do discurso pedagógico.

Curiosamente, essa tentativa de exploração de todos os textos também revela o cumprimento de uma tarefa mais do que uma diversificação da abordagem do tema. Recorrer a todos os textos significa, então, perseguir o PDV supostamente proposto pela universidade. Nesse sentido, para obedecer a ele, seria necessário (e suficiente) fazer remissão a todos os textos da coletânea. A construção do PDV ficaria, portanto, à mercê da obediência (ou tentativa de obediência) das coerções do gênero (não seguir o solicitado anula a redação) e do destinatário. Em seu perfil ampliado, o destinatário privilegiado vem delineado pelos critérios de correção da prova constantes do manual do candidato e, também, em grande medida, reproduzido a partir da imagem que o escrevente faz de seus professores, baseando-se, especialmente, nas réplicas treinadas em sala de aula. Em ambos os casos (no manual ou nas aulas frequentadas), há um dado de realidade que sustenta e valida as escolhas dos escreventes.

No que se refere ao diálogo com cada um dos fragmentos/instrução, a classificação dos textos obedece ao critério de solidarização ou recusa de PDVs ligados a um dado fragmento. A maior incidência de solidarização ocorre no diálogo com o terceiro fragmento (o trabalho de arte), como se pode notar na Tabela 3: 
Tabela 3: A ordem dos textos da coletânea e o diálogo com os fragmentos

\begin{tabular}{|c|c|c|c|c|c|c|c|c|c|c|}
\hline \multirow[b]{2}{*}{ PDV } & \multirow{2}{*}{\multicolumn{2}{|c|}{$\begin{array}{c}\text { MESMA ORDEM } \\
\text { DA } \\
\text { COLETÂNEA } \\
\text { (T1, T2, T3) } \\
\text { ou } \\
\text { (T1, T2, T3 } \\
+ \\
\text { conclusão) }\end{array}$}} & \multicolumn{6}{|c|}{$\begin{array}{c}\text { ORDENS DIFERENTES DA ORDEM } \\
\text { COLETÂNEA } \\
\text { QUE SE DESTACAM } \\
\text { POR BAIXA OU ALTA FREQUÊNCIA }\end{array}$} & \multirow{2}{*}{\multicolumn{2}{|c|}{ TOTAL }} \\
\hline & & & \multicolumn{2}{|c|}{$\begin{array}{c}\text { VARIADAS } \\
\text { ORDENS } \\
\text { DIFERENTES } \\
\text { DA ORDEM } \\
\text { COLETÂNEA }\end{array}$} & \multicolumn{2}{|c|}{$\begin{array}{c}\text { ORDEM } \\
\text { DIFERENTE } \\
\text { CENTRADA } \\
\text { NO } \\
\text { SEGUNDO } \\
\text { TEXTO }\end{array}$} & \multicolumn{2}{|c|}{$\begin{array}{l}\text { ORDEM } \\
\text { INVERTIDA } \\
\text { (T3, T2, T1) }\end{array}$} & & \\
\hline $1 \mathrm{~S}$ & 7 & $2,5 \%$ & 24 & $8,9 \%$ & - & - & 01 & $0,4 \%$ & 32 & $11,9 \%$ \\
\hline $2 S$ & 6 & $2,3 \%$ & 7 & $2,5 \%$ & 10 & $3,7 \%$ & - & - & 23 & $8,5 \%$ \\
\hline $3 S$ & 108 & $40 \%$ & 52 & $19,3 \%$ & - & - & - & - & 160 & $59,3 \%$ \\
\hline $1 \mathrm{R}$ & 1 & $0,4 \%$ & - & - & - & - & - & - & 1 & $0,4 \%$ \\
\hline $2 \mathrm{R}$ & 9 & $3,4 \%$ & 19 & $7,0 \%$ & 15 & $5,6 \%$ & & - & 43 & $16,0 \%$ \\
\hline $3 R$ & 3 & $1,0 \%$ & 3 & $1,0 \%$ & - & - & - & - & 6 & $2,0 \%$ \\
\hline INSTRUÇÃO & 4 & $1,5 \%$ & 1 & $0,4 \%$ & - & - & - & - & 5 & $1,9 \%$ \\
\hline & 138 & $51,1 \%$ & 106 & $39,2 \%$ & 25 & $9,3 \%$ & 01 & $0,4 \%$ & 270 & $100 \%$ \\
\hline $\begin{array}{l}\text { Onde: } \\
\text { S é solidari } \\
\text { respectivos } \\
\text { terceiro fragr }\end{array}$ & $\begin{array}{l}\text { ão c } \\
\text { gmen } \\
\text { nto; } 3\end{array}$ & $\begin{array}{l}\text { PDV; } \\
\text { a colet } \\
\text { recusa }\end{array}$ & $\begin{array}{l}\text { é a } \\
\text { ea. } \\
\text { o PD }\end{array}$ & $\begin{array}{l}\text { usa ao } \\
\text { m, por } \\
\text { o terce }\end{array}$ & n & $\begin{array}{l}\text { nume } \\
3 S \\
\text { nto. }\end{array}$ & ões & $\begin{array}{l}2 \text { e } 3 \\
\text { zação }\end{array}$ & efere & $\begin{array}{l}\text {-se aos } \\
\text { PDV do }\end{array}$ \\
\hline
\end{tabular}

A construção do PDVD nos textos que tomam a coletânea/instrução como elemento estruturador da sua organização composicional, escolhendo um fragmento como privilegiado, aponta, portanto, para uma tendência a privilegiar o terceiro fragmento, o que não deixa de ser, no próprio ato de escolha, um modo de qualificar o trabalho.

Quando o diálogo é exclusivamente com o terceiro fragmento também prevalece maior incidência da manutenção da mesma ordem dos textos da 
coletânea na estruturação das redações, com $40 \%$ de ocorrências, pouco mais que o dobro daqueles em que essa reprodução não prevaleceu. Há, nesse sentido, uma sobreenunciação, ou seja, a construção do PDVD. Essa sobreenunciação se estabelece tanto pela reprodução da ordem da coletânea na estruturação do texto, conforme já mostrado, quanto pelo privilégio de um PDVD proveniente de um fragmento que se adaptaria melhor ao perfil de candidato suposto como o ideal para a instituição avaliadora. Predomina a suposição de que o trabalho de arte teria mais chances de ser valorizado no ambiente universitário.

A segunda maior incidência nesses diálogos se deu com o segundo fragmento, $16 \%$ das ocorrências, cujo PDVD predominante no segundo fragmento da coletânea (a divisão social do trabalho se marca pela exploração do homem) é refutado pelo escrevente em favor da construção de outro, que valoriza o trabalho de modo geral, embora não incida na qualificação sobre o trabalho de arte, ocorrendo, desse modo, a subenunciação do PDVD do segundo fragmento da coletânea. A valorização do trabalho seria justificada por sua importância para a sobrevivência e porque traria dignidade para a humanidade.

Apresento, a seguir, a Tabela 4, que mostra a relação entre o tipo de ensino médio cursado pelo vestibulando (particular ou público) e a frequência ou não a cursinho preparatório para o exame vestibular. Saliento que na classificação dos resultados a partir dessas duas variáveis, contei apenas com 267 (duzentos e sessenta e sete) textos do total de 270 . Portanto, em três dos textos do material, as informações relativas à procedência escolar do aluno não constavam do questionário socioeconômico preenchido pelo vestibulando. 
Tabela 4: Comparativo entre a estruturação das redações e tipos de ensino/frequência a cursinho preparatório

\begin{tabular}{|c|c|c|c|c|c|c|c|c|c|c|c|}
\hline \multirow{2}{*}{ 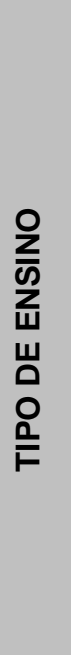 } & \multirow{2}{*}{ 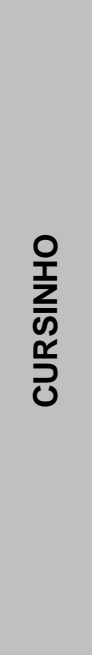 } & \multirow{2}{*}{\multicolumn{2}{|c|}{$\begin{array}{c}\text { MESMA } \\
\text { ORDEM } \\
\text { DA } \\
\text { COLETÂNEA } \\
\text { (T1, T2, T3) } \\
\text { ou } \\
\text { (T1, T2, T3 } \\
+ \\
\text { conclusão) }\end{array}$}} & \multicolumn{6}{|c|}{$\begin{array}{l}\text { ORDENS DIFERENTES DA ORDEM } \\
\text { COLETÂNEA } \\
\text { QUE SE DESTACAM } \\
\text { POR BAIXA OU ALTA FREQUÊNCIA }\end{array}$} & \multirow{2}{*}{\multicolumn{2}{|c|}{ TOTAL }} \\
\hline & & & & \multicolumn{2}{|c|}{$\begin{array}{c}\text { VARIADAS } \\
\text { ORDENS } \\
\text { DIFERENTES } \\
\text { DA ORDEM } \\
\text { COLETÂNEA }\end{array}$} & \multicolumn{2}{|c|}{$\begin{array}{c}\text { ORDEM } \\
\text { DIFERENTE } \\
\text { CENTRADA } \\
\text { NO } \\
\text { SEGUNDO } \\
\text { TEXTO }\end{array}$} & \multicolumn{2}{|c|}{$\begin{array}{c}\text { ORDEM } \\
\text { INVERTIDA } \\
(\mathrm{T} 3, \mathrm{~T} 2, \mathrm{~T} 1)\end{array}$} & & \\
\hline \multirow{2}{*}{$\frac{.0}{\frac{.0}{3}}$} & $\stackrel{\frac{\varepsilon}{D}}{\stackrel{\frac{?}{c}}{\frac{5}{\omega}}}$ & 18 & $6,7 \%$ & 17 & $6,3 \%$ & 1 & $0,4 \%$ & 1 & $0,4 \%$ & 37 & $13,8 \%$ \\
\hline & ठํ & 38 & $14,2 \%$ & 25 & $14,2 \%$ & 8 & $3,0 \%$ & 0 & 0 & 71 & $26,5 \%$ \\
\hline \multirow{2}{*}{ 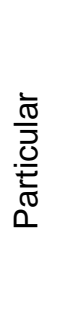 } & $\underset{\infty}{\frac{\varepsilon}{\infty}} \stackrel{\frac{?}{c}}{\frac{5}{5}}$ & 29 & $10,8 \%$ & 30 & $10,8 \%$ & 9 & $3,3 \%$ & 0 & 0 & 68 & $25,5 \%$ \\
\hline & ठ & 49 & $18,4 \%$ & 33 & $18,4 \%$ & 7 & $2,6 \%$ & 0 & 0 & 89 & $33,4 \%$ \\
\hline \multirow{2}{*}{ 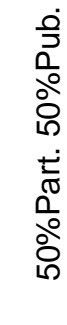 } & $\stackrel{\frac{\varepsilon}{D}}{\infty} \frac{\stackrel{?}{\frac{c}{c}}}{\omega}$ & 0 & 0 & 1 & $0,4 \%$ & 0 & 0 & 0 & 0 & 1 & $0,4 \%$ \\
\hline & हो & 1 & $0,4 \%$ & 0 & 0 & 0 & 0 & 0 & 0 & 1 & $0,4 \%$ \\
\hline & & 135 & $50,6 \%$ & 106 & $39,7 \%$ & 25 & 9,3\%\% & 1 & $0,4 \%$ & $267^{*}$ & $100 \%$ \\
\hline
\end{tabular}

*Dos 270 textos analisados, três não possuem o questionário completo.

Observa-se, na Tabela 4, que a variável com cursinho foi relevante para a organização da redação, tendendo a favorecer a manutenção da estrutura da 
redação na mesma ordem de aparecimento dos textos dos fragmentos, com 14,2\% no ensino público e $18,4 \%$ no particular, totalizando $32,6 \%$ dos 267 textos. No caso da variável ensino público, essa incidência foi maior do que o dobro para os que frequentaram cursos preparatórios para o vestibular em relação aos que não os frequentaram: 14,2\% com cursinho e 6,7\% sem cursinho. Os índices mostram que essa mesma variável - com cursinho - não foi preponderante no quesito ordem diferente da coletânea que, considerado o tipo de ensino (público ou particular), manteve a diferença numa escala inferior a $3 \%$.

Esse resultado não permite afirmar que os cursos preparatórios recomendem a exploração dos textos na ordem em que aparecem na coletânea. No entanto, há, nessa prática, alguma regularidade que permite aventar a hipótese de uma ênfase na necessidade de replicar a todos os textos, o que acaba por ser atendido na ordem dada pela coletânea, como se os escreventes respondessem a perguntas de um questionário (evitam fuga ao tema, afinal, obrigatório), ligadas sequencialmente por remissões temporais (marcam-se como conhecedores da história, são críticos) e por operadores argumentativos mais ou menos canônicos no início dos parágrafos (o que, a partir do segundo parágrafo, marcaria a competência linguística quanto ao tipo de texto e ao gênero do discurso produzidos).

Os índices mostram uma tendência de, no ensino particular, a variável com ou sem cursinho ter menor impacto do que no ensino público. Essa indiferença no ensino particular aponta para um ensino mais uniforme nessas escolas, pelo menos no que se refere à suposta orientação de relacionar cada fragmento da coletânea a um parágrafo da redação. Interessante observar que, na organização em que o diálogo se estabelece com apenas um texto da coletânea (T2), frequentar ou não a cursinho não foi significativo no ensino particular. Os dados sugerem, igualmente, que no ensino público não haveria a mesma preocupação com a leitura e reprodução termo a termo da coletânea, sendo delegada essa preocupação aos cursos preparatórios.

Considerando apenas a variável frequência ou não a cursinho, pode-se observar, na Tabela 5, como se comportam os quesitos manutenção ou não da ordem dos textos da coletânea, na estruturação das redações: 
Tabela 5: Comparativo entre a estruturação das redações e a frequência a curso preparatório

\begin{tabular}{|c|c|c|c|c|c|c|c|c|c|c|}
\hline \multirow{2}{*}{ 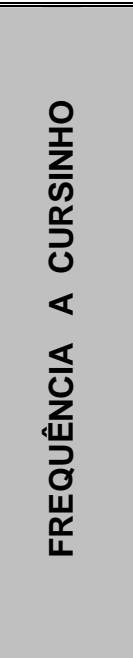 } & \multirow{2}{*}{\multicolumn{2}{|c|}{$\begin{array}{c}\text { MESMA } \\
\text { ORDEM } \\
\text { DA } \\
\text { COLETÂNEA } \\
\text { (T1, T2, T3) } \\
\text { ou } \\
\text { (T1, T2, T3 } \\
+ \\
\text { conclusão) }\end{array}$}} & \multicolumn{6}{|c|}{$\begin{array}{c}\text { ORDENS DIFERENTES DA ORDEM } \\
\text { COLETÂNEA } \\
\text { QUE SE DESTACAM } \\
\text { POR BAIXA OU ALTA FREQUÊNCIA }\end{array}$} & \multirow{2}{*}{\multicolumn{2}{|c|}{ TOTAL }} \\
\hline & & & \multicolumn{2}{|c|}{$\begin{array}{l}\text { VARIADAS } \\
\text { ORDENS } \\
\text { DIFERENTES } \\
\text { DA ORDEM } \\
\text { COLETÂNEA }\end{array}$} & \multicolumn{2}{|c|}{$\begin{array}{c}\text { ORDEM } \\
\text { DIFERENTE } \\
\text { CENTRADA } \\
\text { NO } \\
\text { SEGUNDO } \\
\text { TEXTO }\end{array}$} & \multicolumn{2}{|c|}{$\begin{array}{c}\text { ORDEM } \\
\text { INVERTIDA } \\
(\mathrm{T} 3, \mathrm{~T} 2, \mathrm{~T} 1)\end{array}$} & & \\
\hline 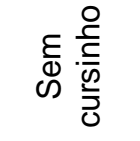 & 47 & $17,6 \%$ & 48 & $18 \%$ & 10 & $3,7 \%$ & 1 & $0,4 \%$ & 106 & $39,7 \%$ \\
\hline 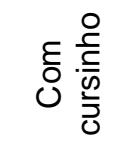 & 88 & $33,0 \%$ & 58 & $21,7 \%$ & 15 & $5,6 \%$ & 0 & 0 & 161 & $60,3 \%$ \\
\hline TOTAL & 135 & $50,6 \%$ & 106 & $39,7 \%$ & 25 & $9,3 \%$ & 1 & $0,4 \%$ & 267 & $100 \%$ \\
\hline
\end{tabular}

Estes resultados apenas reafirmam a maior influência dos cursinhos preparatórios no quesito manutenção da mesma ordem da coletânea na estruturação da redação. Além da maior atenção à necessidade de leitura e réplica à coletânea, interpreto esses percentuais como resultantes das dicas passadas para os alunos durante os cursinhos preparatórios para o exame vestibular, que consistem em orientar os alunos a relacionar cada um dos fragmentos de uma coletânea a um parágrafo da redação, para não incorrer no risco de deixar algum texto da coletânea de fora da discussão, cumprindo o solicitado na instrução. Esses resultados corroboram a interpretação de que a relação entre a reprodução da ordem dos textos da coletânea na estruturação do texto do vestibulando foi determinante de um modo específico de enunciar: a sobreenunciação e, nesse caso, o PDVD é o da valorização do trabalho intelectual (de arte). Eles apontam para um modo de ler e interpretar os fragmentos da coletânea, isto é, de mostrar, no texto, 
que foi cumprida a tarefa solicitada na instrução da prova e que, além disso, foi dada uma resposta ao letramento escolar adquirido sobre o gênero redação de vestibular, inclusive no que se refere ao que foi valorizado no desenvolvimento temático.

No que se refere à qualificação, destaco, uma vez mais, desse diálogo dos textos do vestibulando com a ordem dos textos da coletânea, um modo de qualificação particular do trabalho, que está em relação direta com o estabelecimento de um diálogo avaliativo dos PDVs da coletânea.

\subsection{Classificação e interpretação dos resultados relacionados às representações sociais}

A análise dos exemplos constantes no capítulo 4, que tratou da construção do PDVD em relação às representações sociais, revelou diferentes representações sociais do escrevente sobre o trabalho, sobre a universidade e sobre os saberes provenientes de outras esferas.

No que se refere às representações sociais do trabalho depreendidas do diálogo do escrevente com os textos da coletânea, no primeiro fragmento revela-se a representação social do trabalho construída principalmente pelo tom conceitual (trabalho é/ trabalho não é) vinculado à origem do trabalho. Esse fato responde ao enunciado da instrução, que afirma que o primeiro fragmento trata da definição de trabalho.

Além disso, o recurso ao uso do tom conceitual é também uma resposta ao discurso pedagógico, que vincula a construção do PDV ao PDV do destinatário, no que se refere às supostas orientações de professores para se trabalhar temas como o do trabalho. Prova disso, é a circulação desse tom, de modo geral, na totalidade das redações analisadas. $E$, nesse caso, a qualificação pela adjetivação tem papel importante na construção do PDV, por meio da formulação trabalho é/não é + adjetivo/ou expressão adjetiva. A representação social do trabalho que prevalece no diálogo com o primeiro fragmento é a vinculada ao PDVD que afirma que o trabalho não vai acabar devido à sua importância para a humanidade. A construção dessa representação se dá por uma adjetivação axiologizada e intensificada com valores eufóricos ligados principalmente ao primeiro fragmento. Trata-se, assim, de uma representação estereotipada, no sentido de que, na sociedade atual, é certo que o 
trabalho não vai acabar. Essa representação social do trabalho se prende aos PDVs da coletânea.

No que se refere ao segundo fragmento, a representação social do trabalho que se destaca é a vinculada à recusa aos PDVs desse fragmento. O trabalho, nessa representação, é gerador de desigualdade, por meio dele o trabalhador é explorado e sofre, mas em razão da sua "intrínseca" importância para a humanidade, em função de ser o provedor de seu sustento, precisa/deve mudar. Destaca-se da construção dessa representação, a formulação adjetiva que imprime o tom deôntico: é necessário, é preciso, principalmente nos parágrafos conclusivos, mas não exclusivamente neles, em virtude da necessidade de mudança do trabalho que espalha sofrimento e exploração. O caráter de denúncia presente nos textos aponta para uma qualificação altamente modalizada e axiologizada. Esse tom denunciatório revela que, na construção dessa representação social do trabalho, o escrevente representa a si, um sujeito que busca a justiça e, por isso, cidadão consciente, bem como constrói uma representação de seu outro. A construção dessa representação reforça que o PDVD a ela vinculado é remetido ao PDV do destinatário. A tentativa do escrevente é construir de si a imagem do sujeito crítico e que assume um posicionamento contundente por meio da adjetivação e da modalização. Essa representação revela o tom ideológico que a perfaz. Nela, assume-se o posicionamento de denúncia do que oprimiria o trabalhador. 0 escrevente se valoriza, para ser valorizado e aprovado no exame.

A representação social do trabalho aplicada ao terceiro fragmento que prevalece é aquela que se vincula do PDVD que relaciona trabalho ao prazer, à felicidade, à realização, à notoriedade, beleza, liberdade, estabelecendo um tom eufórico bastante recorrente nas redações. Na construção dessa representação, o tom conceitual também se faz presente e é correlato do terceiro fragmento que também apresenta uma definição para o trabalho de arte. Essa representação remete a construção do PDVD para o discurso institucional, vinculado ao PDV suposto para o destinatário, em que uma voz dominante se justifica pela alta valorização do trabalho intelectual (de arte), que também é projetada para o trabalho de modo geral, reforçando a imagem que o escrevente constrói de si com vistas a seu destinatário. Destaco dessa representação, as diferentes manifestações da 
qualificação do trabalho: pela própria adjetivação, ou por meio do uso de substantivos ou verbos carregados com valores positivos.

A representação social do escrevente sobre a universidade em sua relação com o que ele imagina ser a representação social do trabalho e do trabalho intelectual (de arte) para a universidade revela o vínculo com o PDVD, em que se valoriza o trabalho intelectual representado pela própria universidade. Esta, por tratar-se do outro do escrevente, isto é, por ser o destinatário privilegiado para quem seu discurso se dirige, não poderia deixar de ser euforizada por alguém que deseja acessar ao ensino superior. O modo de representar a universidade mostra o modo como o escrevente ficcionaliza seu outro para construir uma imagem positiva de si. O PDVD vinculado a essas representações (da universidade, do trabalho e do trabalho intelectual, além da própria escrita) é direcionado para o PDV do destinatário, que põe em jogo um discurso institucionalizado da valorização da educação pelo viés acadêmico. Valorizando a educação, o escrevente está valorizando a si, um candidato ao ensino superior. E se deseja ingressar na universidade, é porque dá a ela um valor positivo. Essa representação da universidade revela-se num discurso ideológico de valorização do trabalho intelectual, que é aceito pelo escrevente sem muito questionamento e, por isso, há um endeusamento da educação como aquela que pode tudo solucionar. Trata-se de uma representação estereotipada, uma vez que esse discurso circula no senso comum e é tomado pelo escrevente como a única verdade. As qualificações, nesse contexto, são bastante euforizadas, exacerbando a valorização positiva dos estudos para se ter o melhor trabalho. A qualificação euforizada remete a construção dessa representação à construção do PDVD, que valoriza igualmente o trabalho intelectual. Além disso, essa qualificação materializa no texto o modo como o escrevente enxerga a universidade e o trabalho intelectual por ela propiciado.

As representações construídas, a partir dos saberes mobilizados pelo escrevente de esferas sociais diferentes da que dispõe imediatamente para fazer a prova - a coletânea -, também se vinculam ao PDVD, remetendo-o para o PDV do destinatário, agora movido pelo saber de autoridade, ou melhor, pelo saber julgado pelo escrevente como de autoridade.

Saliento que estabelecer uma única esfera de mobilização de saberes para cada redação é impossível, do ponto de vista interdiscursivo. Mas, como 
procedimento metodológico, tendo em vista a tabulação dos dados levantados, as esferas foram selecionadas de acordo com a predominância em cada redação. Para a tabulação foram consideradas duas situações: a primeira, que relaciona cada redação a uma esfera predominante, isto é, para cada redação uma única esfera e, a segunda, em que foram combinadas duas esferas predominantes para cada redação. A esfera predominante foi selecionada da média dessas duas situações, resultando a tabulação conforme a Tabela 6:

Tabela 6: Comparativo das esferas mobilizadas pelo escrevente

\begin{tabular}{|c|c|c|c|c|c|}
\hline & $\begin{array}{l}\text { Mobilização } \\
\text { de saberes }\end{array}$ & ESFERAS & \multicolumn{3}{|c|}{ QUANTIDADE } \\
\hline 1 & $\begin{array}{c}\text { Da } \\
\text { Coletânea }\end{array}$ & Fragmentos 1,2 e 3 e instrução & 78 & $29 \%$ & $78-29 \%$ \\
\hline 2 & \multirow{9}{*}{ 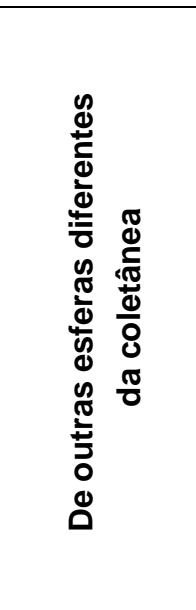 } & Histórica & 61 & $22,6 \%$ & \multirow{9}{*}{$192-71 \%$} \\
\hline 3 & & Popular (Provérbio) & 52 & $19,0 \%$ & \\
\hline 4 & & Religiosa & 27 & $10,0 \%$ & \\
\hline 5 & & $\begin{array}{l}\text { Da projeccão da enunciação no } \\
\text { enunciado }\end{array}$ & 20 & $7,5 \%$ & \\
\hline 6 & & $\begin{array}{l}\text { Do estudo (referências à educação, } \\
\text { formação, etc.) }\end{array}$ & $13^{70}$ & $5,0 \%$ & \\
\hline 7 & & Literária & 7 & $2,6 \%$ & \\
\hline 8 & & Midiática & 7 & $2,6 \%$ & \\
\hline 9 & & $\begin{array}{l}\text { Do mercado cultural (música, cinema, } \\
\text { etc.) }\end{array}$ & 3 & $1,0 \%$ & \\
\hline 10 & & Da saúde & 2 & $0,7 \%$ & \\
\hline & & TOTAL & 270 & $100 \%$ & $270-100 \%$ \\
\hline
\end{tabular}

Como se pode observar, na Tabela 6, comparando a mobilização de saberes da coletânea e de esferas de atividade diferentes da esfera didático-pedagógica da prova de vestibular (embora possam ter a sua memória relançada pela leitura da coletânea), estas têm predominância, apresentando $71,7 \%$ de ocorrências. Esse dado mostra que a maioria dos escreventes não se prende unicamente aos textos fornecidos pela prova de redação; pelo contrário, buscam incrementar seus textos com outros saberes, revelando que atendem às supostas orientações de seus professores para mostrar que detêm conhecimentos variados. Entretanto, essa variação não é extensa, se considerarmos a quantidade de esferas diferentes, apenas nove, excluindo-se a da coletânea, como se pode ver na Tabela 7:

\footnotetext{
${ }^{70}$ Como procedimento metodológico e logístico, deixei de fora desse item as redações cujo destaque foi a projeção da enunciação no enunciado, uma vez que em todas essas redações constava também valorização à educação/estudo.
} 
Tabela 7: Esferas diferentes da coletânea

\begin{tabular}{|c|c|c|c|c|}
\hline & \multicolumn{2}{|l|}{ ESFERAS } & \multicolumn{2}{|c|}{ QUANTIDADE } \\
\hline \multirow{5}{*}{1} & \multicolumn{2}{|l|}{ Histórica } & \multirow{5}{*}{61} & \multirow{5}{*}{$32 \%$} \\
\hline & Histórica - revolução industrial & 31 & & \\
\hline & Histórica - Marx & 13 & & \\
\hline & Do trabalho & 05 & & \\
\hline & Outros fatos & 12 & & \\
\hline \multirow{3}{*}{2} & \multicolumn{2}{|l|}{ Popular (Provérbio) } & \multirow{3}{*}{52} & \multirow{3}{*}{$27 \%$} \\
\hline & O trabalho dignifica & 49 & & \\
\hline & Outros provérbios & 03 & & \\
\hline \multirow{5}{*}{3} & \multicolumn{2}{|l|}{ Religiosa } & \multirow{5}{*}{27} & \multirow{5}{*}{$14 \%$} \\
\hline & Provérbio baseado no mito de Adão & 10 & & \\
\hline & Fatos bíblicos & 8 & & \\
\hline & Religião não cristã & 2 & & \\
\hline & Referências à religião & 7 & & \\
\hline 4 & \multicolumn{2}{|c|}{ Da projeção da enunciação no enunciado } & 20 & $10,5 \%$ \\
\hline 5 & \multicolumn{2}{|c|}{$\begin{array}{l}\text { Do estudo (referências à educação, formação, } \\
\text { etc.) }\end{array}$} & 13 & $6,7 \%$ \\
\hline \multirow{3}{*}{6} & \multicolumn{2}{|l|}{ Literária } & \multirow{3}{*}{7} & \multirow{3}{*}{$3,6 \%$} \\
\hline & Ligada ao exame vestibular & 4 & & \\
\hline & Outras literaturas & 3 & & \\
\hline 7 & \multicolumn{2}{|l|}{ Midiática } & 7 & $3,6 \%$ \\
\hline 8 & \multicolumn{2}{|c|}{ Do mercado cultural (música, cinema, etc.) } & 3 & $1,6 \%$ \\
\hline 9 & \multicolumn{2}{|l|}{ Da saúde } & 2 & $1,0 \%$ \\
\hline \multicolumn{3}{|c|}{ TOTAL } & 192 & $100 \%$ \\
\hline
\end{tabular}

No que se refere aos tipos de esferas: as três primeiras (em destaque na Tabela 7), histórica, popular e religiosa, tratam de saberes relacionados mais diretamente ao tema "o trabalho". Nas demais esferas (4 a 9), os saberes relacionados ao trabalho (por exemplo, fatos históricos ligados ao trabalho, como o capitalismo, revolução industrial, Marx e Engels) estão mais diluídos na discussão.

Dentre as esferas mobilizadas, a de maior incidência é a esfera histórica, conforme já dito durante a análise. Essa incidência foi propiciada principalmente a partir do segundo fragmento, que tratou de questões socioeconômicas ligadas ao trabalho, por exemplo, a referência ao capitalismo. Trata-se de uma abordagem do tema trabalho que circula em diferentes esferas, com destaque para a mídia, mas também está relacionada ao saber escolar do escrevente. A incidência maior da 
esfera histórica revela a influência dos letramentos escolares do escrevente em sua escrita. Letramentos assimilados prioritariamente nas aulas de história, mas não exclusivamente nelas, e que se desenvolvem em função de fatos históricos ou da citação de personagens de destaque na história - tidos como conhecidos do destinatário pelo escrevente -, como, por exemplo, a revolução industrial, o fordismo, Karl Marx, dentre outros. O escrevente, ao desenvolver esses temas, quer mostrar a imagem de um sujeito que sabe das causas das injustiças provocadas pelo capitalismo e pelo progresso técnico. Ao tratar, prioritariamente, das relações sociais do trabalho visto como exploração do trabalhador, o escrevente faz-se um sujeito crítico e consciente do que provoca a desigualdade social e deve ser combatido. Desse modo, a representação desses saberes, tomados como de autoridade pelo escrevente, remete, novamente, o PDVD para o PDV suposto para o destinatário.

Foi relevante também a incidência da mobilização de saberes da esfera popular, especificamente, do provérbio "o trabalho dignifica o homem", ou a referência indireta a ele que, considerando apenas a esfera popular atingiu o índice de $94 \%$ das ocorrências de provérbios ${ }^{71}$. Afora a destacabilidade do provérbio, pronto a se encaixar nas mais diversas estruturas textuais, o alto índice do uso desse provérbio aponta para a interpretação de um sujeito que tenta mostrar a importância do trabalho que dignifica o homem, mostrando que prevalece um discurso que circula na sociedade capitalista e que tenta, a todo custo, justificar as mazelas provocadas pela exploração do trabalhador, alegando que o trabalho, mesmo com muito sofrimento, trará dignidade para o trabalhador.

No discurso do escrevente, o tom de mudança foi preponderante no sentido de reconhecer as mazelas do capitalismo, alegando que o trabalho deve deixar de explorar o trabalhador e apenas dignificá-lo. Vale lembrar o que diz Chauí, ao fazer a introdução da obra "o direito à preguiça", de Lafargue:

Donde nossa indagação: como e quando o horror pelo trabalho transformou-se no seu contrário? Quando as palavras honestus e honestiores deixaram de significar os homens livres e passaram a significar o negociante que paga suas dívidas? Quando e por que se passou ao elogio do trabalho como virtude e se viu no elogio do ócio o convite ao vício, impondo-se negá-lo pelo neg-ócio? (CHAUÍ, 1999, p. 13).

\footnotetext{
${ }^{71}$ Nesse índice não estão incluídos os provérbios tratados na esfera religiosa.
} 
Esse discurso revela a natureza ideológica com que é tratado o trabalho. Ele é atualizado nas redações por meio da qualificação avaliativa e axiológica na tomadas de PDVs e na construção do PDVD que, nesse contexto, é remetido ao PDV do destinatário, em função das imagens construídas pelo escrevente.

A esfera religiosa, com a terceira maior incidência, 27\% das ocorrências, também foi frequente o uso de um provérbio, o bíblico, "comerás o pão com o suor do seu rosto", baseado no mito de Adão e Eva, que foram castigados por desobedecerem a Deus, tendo de sofrer trabalhando para o sustento (Adão) e no trabalho de parto (Eva). Justifica-se, assim, o trabalho como castigo e como meio para o sustento. O uso desse provérbio pode estar relacionado ao primeiro fragmento que trata da origem do trabalho. Segundo Chauí:

Não é curioso, porém, que o desprezo pela preguiça e a extrema valorização do trabalho possam existir numa sociedade que não desconhece a maldição que recai sobre o trabalho, visto que trabalhar é castigo divino e não virtude do livrearbítrio humano? Aliás, a idéia do trabalho como desonra e degradação não é exclusiva da tradição judaico-cristã. Essa idéia aparece em quase todos os mitos que narram a origem das sociedades humanas como efeito de um crime cuja punição será a necessidade de trabalhar para viver (CHAUÍ, 1999, p. 11)

Esse discurso moralizante, instituído pela igreja que muito apoiou (e ainda apoia) o capitalismo, mostra o ranço conservador que circula no discurso do escrevente e que também está relacionado a uma justiça capitalista, que tenta justificar o sofrimento do trabalho para se garantir o sustento e escapar da condenação de ser taxado de vagabundo e, por isso, não ser alguém digno. A igreja repudia a preguiça como pecado capital. O escrevente, nesse caso, assume um PDV institucional, ligado à instituição igreja, cuja voz ele trouxe para seu texto por meio desse provérbio.

A esfera da projeção da enunciação no enunciado e a mobilização de saberes ligados à educação: esferas do estudo, literária e do mercado cultural revelam que o escrevente busca mostrar ao seu destinatário privilegiado o que ele quer que seja visto nele, ou seja, a imagem de um candidato portador de conhecimentos que ele julga serem valorizados pela instituição que o avalia. A mobilização de saberes ligados a valorização da educação vista nessas esferas, que juntas reúnem $22,5 \%$, mostra a busca do escrevente por uma verdade validada pelos discursos que 
circulam na sociedade: o de que por meio do estudo tudo de bom se consegue, inclusive o trabalho-prazer. Trata-se da própria valorização do que ele está pleiteando, o ensino universitário e, nesse caso, também construindo sua representação da universidade. Destaco a projeção da enunciação no enunciado, em que o escrevente faz valer um PDV que olha o mundo a partir da visão de um candidato, que quer mostrar que sabe o que está fazendo e de onde está fazendo.

A esfera literária, cujo saber mobilizado tomou por base a bibliografia solicitada no exame para a leitura dos candidatos, evidencia o caráter responsivo da construção de PDVs, uma vez que o escrevente insiste em mostrar seu saber para seu interlocutor presumido. Na mobilização de saberes da esfera da saúde está presente um PDV construído com base no tom denunciatório, de que o trabalho é ruim, é prejudicial ao trabalhador porque, em excesso, provoca nele diversas doenças. O escrevente procura se mostrar como bem informado para seu interlocutor.

O mesmo acontece com a esfera midiática, que poderia estar vinculada a vários desses saberes, uma vez que nela circulam os mais variados discursos, mas, que, por uma questão metodológica (menção explícita à esfera), ficou mais restrita, com 3,7\% das redações. Esses dados revelam o caráter altamente responsivo das redações de vestibular, em que o escrevente se posiciona diante do tema "o trabalho", interdiscursivamente, considerando os valores ideológicos respaldados por uma sociedade capitalista.

Ao comparar a incidência dessas esferas com as variáveis tipo de ensino do vestibulando e frequência ou não a cursinho preparatório, temos um resultado interessante, principalmente no que se refere à mobilização de saberes da esfera histórica, como mostra a tabela 8: 
Tabela 8: Comparativo entre as esferas mobilizadas, tipo de ensino e frequência a cursinho preparatório

\begin{tabular}{|c|c|c|c|c|c|c|c|c|c|c|c|c|}
\hline \multirow{3}{*}{ 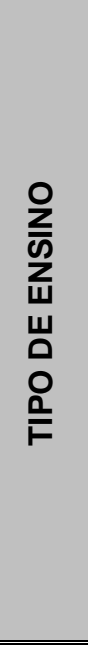 } & \multirow{3}{*}{ 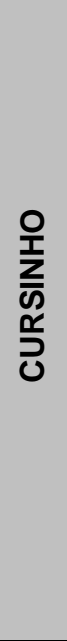 } & \multicolumn{11}{|c|}{ MOBILIZAÇÃO DE SABERES } \\
\hline & & 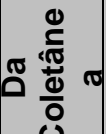 & \multicolumn{9}{|c|}{$\begin{array}{l}\text { De outras esferas diferentes } \\
\text { da coletânea }\end{array}$} & \multirow[b]{2}{*}{ 迹 } \\
\hline & & 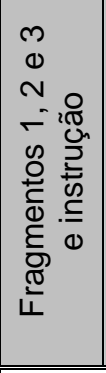 & 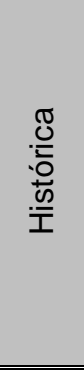 & 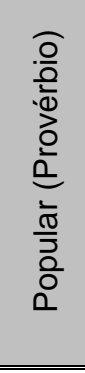 & 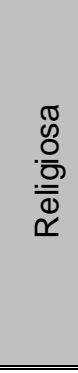 & 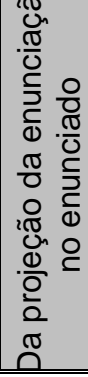 & $\begin{array}{l}\text { 을 } \\
\stackrel{0}{0} \\
0 \\
\circ \\
\circ\end{array}$ & 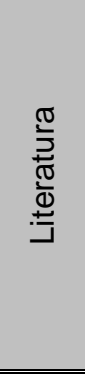 & $\frac{\frac{\pi}{0}}{i \frac{0}{2}}$ & 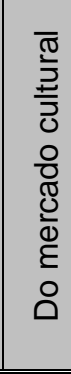 & 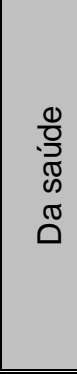 & \\
\hline & & \multicolumn{11}{|c|}{ Porcentagem (\%) } \\
\hline \multirow{2}{*}{$\frac{.0}{\frac{0}{0}}$} & 这 & 4,5 & 0,4 & 2,2 & 1,9 & 0,7 & 1,0 & 0,4 & 0,4 & 0,7 & 0 & 12,3 \\
\hline & $\sum_{\omega}$ & 8,6 & 7,5 & 4,5 & 3,0 & 1,9 & 1,9 & 0 & 0 & 0 & 0,37 & 27,7 \\
\hline \multirow{2}{*}{ 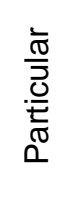 } & 足 & 6,7 & 6,3 & 5,6 & 2,6 & 1,9 & 0 & 1,0 & 0,7 & 0 & 0,37 & 25,8 \\
\hline & $\sum_{\infty}$ & 8,2 & 8,2 & 6,7 & 2,2 & 8 & 1,9 & 1,0 & 1,5 & 0,4 & 0 & 33,4 \\
\hline \multirow{2}{*}{ 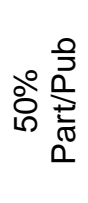 } & 足 & 0,4 & 0 & 0 & 0 & 0 & 0 & 0 & 0 & 0 & 0 & 0,4 \\
\hline & $\underset{\infty}{\infty}$ & 0 & 0 & 0 & 0,4 & 0 & 0 & 0 & 0 & 0 & 0 & 0,4 \\
\hline \multicolumn{2}{|c|}{ Total } & 29,0 & 22,6 & 19,0 & 10,0 & 7,5 & 5,0 & 2,6 & 2,6 & 1,0 & 0,7 & 100,0 \\
\hline
\end{tabular}


Destaco, da Tabela 8, a alta incidência da mobilização de saberes entre os vestibulandos que estudaram em escola pública e frequentaram cursinho preparatório. Destaco desses índices, a esfera histórica, em que a frequência a cursos preparatórios alcança o índice vinte vezes maior do que o dos que não os frequentam. A esfera histórica, como visto na análise, evidencia um tratamento dado ao tema do trabalho, seja pela abordagem de acontecimentos históricos, seja pela discussão sobre temas como o capitalismo e o progresso técnico, assuntos vinculados ao segundo fragmento, que na totalidade do corpus, obteve expressiva discussão, mesmo naqueles textos que dialogaram com os três fragmentos da coletânea. Esse percentual pode estar vinculado a um modo de atuação dos cursos preparatórios, que priorizam o tratamento histórico aos temas de redação. Ao contrário, no ensino particular, essa variável comportou-se como pouco significativa, levando à conclusão de que, no ensino particular, se trabalha com modelo de ensino da redação semelhante ao dos cursinhos e, nesse caso, a variável frequência a cursinho não se fez relevante. Essas mesmas considerações da esfera histórica podem ser projetadas para a esfera da coletânea, se considerado o tratamento dado ao segundo fragmento na totalidade do corpus. No quesito escola pública, somando essas duas esferas (coletânea e histórica) $(12+1$ e $23+20)$, triplica-se a diferença na variável frequência a cursinho, Tabela 9:

Tabela 9: Comparativo frequência a cursinho em ensino público

\begin{tabular}{|c|c|c|}
\hline $\begin{array}{c}\text { TIPO DE } \\
\text { ENSINO }\end{array}$ & CURSINHO & $\begin{array}{c}\text { Coletânea + } \\
\text { Histórica }\end{array}$ \\
\hline \multirow{2}{*}{ Público } & NÃO & 13 \\
\cline { 2 - 3 } & SIM & 43 \\
\hline
\end{tabular}

Esses resultados evidenciam a remissão do PDVD ao PDV suposto para o destinatário, pela presença do alto índice de um discurso pedagógico, que se apoia nessa prática de ensino da escrita e, em particular, de treinamento de redação de vestibular. Outro fato que reforça essa conclusão é o índice alcançado, na esfera histórica, pela mobilização de saberes vinculados a fatos históricos e à revolução industrial, tema trabalhado nas disciplinas de história, com 31 ocorrências (50\% de 61 redações, conforme Tabela 7), que poderia ser relacionado à esfera escolar, no sentido de mais restritos (mas não exclusivos) à escola. 
O recurso ao uso do provérbio, nos textos que dialogaram com a esfera popular, também reflete o tratamento histórico dado ao tema, uma vez que também foi priorizada a discussão pautada no segundo fragmento da coletânea, mesmo que dialogando com os demais fragmentos. Novamente, a variável frequência a cursinho se destaca, reforçando as conclusões já postas.

Essa discussão passa a impressão de um tom monocórdico presente na totalidade dessas redações, em que se discute o já-discutido, o já-posto, ou seja, um discurso que circula no senso comum, que não possui um único responsável por esse dizer, porque é um PDV coletivo e que, por isso, é impermeável à desconstrução.

Se desconsiderada apenas a variável frequência a cursinho, a interpretação dada à influência do discurso pedagógico no ensino do gênero redação de vestibular é ainda mais marcante. Como se pode notar na Tabela 10:

Tabela 10: Comparativo entre as diferentes esferas e a frequência a cursinho preparatório

\begin{tabular}{|l|c|c|c|c|c|c|}
\hline \multirow{2}{*}{ ESFERAS } & \multicolumn{3}{|c|}{ FREQUÊNCIA A CURSINHO } & \multicolumn{2}{c|}{ TOTAL } \\
\cline { 2 - 7 } & SIM & $\%$ & NÃO & $\%$ & & $\%$ \\
\hline Da coletânea & 45 & $\mathbf{1 6 , 8}$ & 31 & $\mathbf{1 1 , 6}$ & 76 & $\mathbf{2 8 , 5}$ \\
\hline Histórica & 43 & $\mathbf{1 6 , 0}$ & 18 & $\mathbf{6 , 6}$ & 61 & $\mathbf{2 2 , 6}$ \\
\hline Popular (Provérbio) & 30 & $\mathbf{1 1 , 2}$ & 21 & $\mathbf{7 , 8}$ & 51 & $\mathbf{1 9 , 0}$ \\
\hline Religiosa & 15 & $\mathbf{5 , 6}$ & 12 & $\mathbf{4 , 4}$ & 27 & $\mathbf{1 0 , 0}$ \\
\hline $\begin{array}{l}\text { Da projeção da } \\
\text { enunciação no } \\
\text { enunciado }\end{array}$ & 13 & $\mathbf{4 , 8}$ & 7 & $\mathbf{2 , 6}$ & 20 & $\mathbf{7 , 5}$ \\
\hline Do estudo & 10 & $\mathbf{3 , 8}$ & 3 & $\mathbf{1 , 0}$ & 13 & $\mathbf{5 , 0}$ \\
\hline Literária & 3 & $\mathbf{1 , 0}$ & 4 & $\mathbf{1 , 6}$ & 7 & $\mathbf{2 , 6}$ \\
\hline Midiática & 4 & $\mathbf{1 , 6}$ & 3 & $\mathbf{1 , 0}$ & 7 & $\mathbf{2 , 6}$ \\
\hline Do mercado cultural & 1 & $\mathbf{0 , 3 7}$ & 2 & $\mathbf{0 , 7}$ & 3 & $\mathbf{1 , 0}$ \\
\hline Da saúde & 1 & $\mathbf{0 , 3 7}$ & 1 & $\mathbf{0 , 3 7}$ & 2 & $\mathbf{0 , 7}$ \\
\hline \multicolumn{1}{|c|}{ TOTAL } & 165 & $\mathbf{6 1 , 5}$ & 102 & $\mathbf{3 8 , 5}$ & 267 & $\mathbf{1 0 0 , 0 \%}$ \\
\hline \hline
\end{tabular}

No comportamento dos índices com a variável frequência a cursinho, Tabela 10, salta aos olhos a incidência positiva (com exceção das esferas literária, do mercado cultural e da saúde, cuja incidência é oposta). Para não ser repetitiva, destaco dessa tabela apenas o resultado das esferas da projeção da enunciação no 
enunciado e estudo, ambas vinculadas ao mesmo tratamento dado ao tema, no sentido de construírem o PDV voltado para os saberes relacionados à educação e, como visto nas análises, que remetem à representação da universidade, cuja posição em relação ao trabalho intelectual é a hierarquicamente superior. A variável positiva da frequência a cursinho é bastante incidente no resultado, sendo praticamente $50 \%$ na esfera da projeção da enunciação no enunciado e mais que o triplo na esfera do estudo. Esse resultado traz à tona a alta valorização, dada pelos cursinhos, a esses saberes, ou ao que eles tentam projetar na escrita do vestibulando, reforçando a conclusão relatada anteriormente sobre o discurso pedagógico, em que se valorizam determinados saberes e o modo como isso deve se manifestar na escrita da redação de vestibular.

Dessas esferas, diferentes PDVs convergem para um PDVD. A mobilização desses saberes, tomados pelo escrevente como de autoridade, conduzem o PDVD para o PDV do destinatário. O escrevente, para atender a seu outro/Outro, tenta mostrar-se portador de conhecimentos tido como de autoridade para sensibilizar o corretor, bem como para validar o seu dizer e a visão de mundo construída em seu texto, mesmo que ela não seja a sua própria, mas que igualmente a valoriza em função de seu destinatário. Tem-se, assim, um sobreenunciador, isto é, o PDV que valoriza o trabalho e prioritariamente o trabalho intelectual/de arte.

Nem sempre o PDVD é, propriamente, o do escrevente, a não ser no sentido de que ele foi construído a partir do PDV do outro/Outro, ou melhor, na correlação com outros PDVs. Trata-se do diálogo do escrevente com os textos fornecidos pela prova, bem como do diálogo com discursos Outros (interdiscurso). O PDVD é, pois, construído no cruzamento dessas vozes, na correlação com outros PDVs. No diálogo com a coletânea, prevalecem os PDVs tomados pelo escrevente a partir da valorização do trabalho e do trabalho intelectual (de arte). Esses PDVs são atualizados nos redações, por meio das adjetivações e modalizações, ou seja, o escrevente toma para si o PDV da valorização do trabalho, seja da coletânea ou de fora dela e o amplia com a qualificação avaliativa e axiológica. Esse trabalho de construção do PDVD na correlação com outros PDVs evidencia o trabalho do sujeito com a linguagem.

$\mathrm{Na}$ totalidade do corpus, o fragmento mais privilegiado é o terceiro. Esse privilégio é resultado do interlocutor presumido pelo gênero, a banca corretora, 
representante da universidade. Observa-se um modo recorrente de marcar posicionamentos enunciativos, visto que determinadas posições se repetem na totalidade do corpus para firmar uma mesma representação social do trabalho: a que valoriza o trabalho intelectual em detrimento dos demais tipos de trabalho. No que se refere aos outros dois fragmentos da coletânea, na sequência dessa escala, está o segundo fragmento, que ocupa lugar privilegiado na discussão sobre as relações do trabalho no mundo contemporâneo, especificamente, e sobre a sua importância para a sobrevivência. As marcas das réplicas aos enunciados da coletânea permeiam o todo das redações, mas, de maneira marcante, o diálogo com o terceiro fragmento é mais incidente no parágrafo conclusivo. No que se refere ao primeiro fragmento, algumas vezes é tomado como recorte para introdução ao tema. Em outras, há um procedimento intertextual com a definição dada no primeiro fragmento, seja para confluir para o mesmo posicionamento do fragmento, ou para conduzir a outro posicionamento, por meio de uma definição, diferente e às vezes oposta à do primeiro fragmento.

\subsection{Relação dialógica entre a construção do PDVD e os PDVs depreendidos pelo escrevente}

A análise das redações permitiu constatar que o escrevente, para construir seu PDV, necessita apropriar-se de outros PDVs. Estes tomados da relação dialógica com: (a) os PDVs da coletânea, fonte imediata disponível para o escrevente ou (b) os PDVs da mobilização de saberes de esferas diferentes da coletânea. De modo geral, a retomada de PDVs desdobra-se ou não em outros PDVs. Encontrei três diferentes modos de desdobramentos: 1) aquele em que o escrevente apenas reafirma os PDVs mobilizados, se solidarizando (S) com eles, nesse caso, ele coenuncia com esses mesmos PDVs; 2) aquele em que 0 escrevente se distancia dos PDVs mobilizados, refutando-os $(R)$, para construir outros PDVs. Ao refutá-los, ele subenuncia esses PDVs; e 3) aquele em que o escrevente mobiliza outros PDVs, assumindo-os ou não, para construir outro PDV que é sobreposto aos demais PDVs, isto é, ele sobreenuncia para construir o PDVD na correlação com os PDVs mobilizados. 
Considerando os movimentos de solidarização e de recusa dos PDVs da coletânea, em sua relação com a qualificação do trabalho, temos as descrições desses movimentos, logo abaixo, e sua composição na totalidade do corpus, Tabela 11:

\section{Descrição dos PDVs:}

Valorização do trabalho - T (+)

Fragmento 1 (1S): Trabalho é importante e não vai acabar;

Fragmento 2 (2R): Trabalho deve deixar de ser exploração, porque é importante para a sobrevivência da humanidade;

Fragmento 3 (3S): Trabalho é importante e deve ser como o trabalho intelectual (de arte).

\section{Depreciação do trabalho - T (-)}

Fragmento $1(1 \mathrm{R})$ : Trabalho é prejudicial e deve acabar;

Fragmento 2 (2S): Trabalho é prejudicial, é exploração;

Fragmento 3 (3R): Trabalho intelectual (de arte) não é importante.

Instrução: não há uma avaliação efetiva, assumem-se os PDVs da instrução.

Tabela 11: panorama dos PDVs

\begin{tabular}{|c|c|c|c|}
\hline PDV & \multicolumn{2}{|c|}{ TOTAL } & $\begin{array}{l}\text { TOTAL } \\
\text { GERAL }\end{array}$ \\
\hline $1 S$ & 032 & $11,9 \%$ & \multirow{3}{*}{$\begin{array}{c}\mathrm{T}(+) \\
235 \\
87,9 \%\end{array}$} \\
\hline $2 \mathrm{R}$ & 043 & $16,0 \%$ & \\
\hline $3 S$ & 160 & $59,3 \%$ & \\
\hline $1 \mathrm{R}$ & 001 & $0,4 \%$ & \multirow{3}{*}{$\begin{array}{c}\mathrm{T}(-) \\
030 \\
11,2 \%\end{array}$} \\
\hline $2 S$ & 023 & $8,5 \%$ & \\
\hline $3 R$ & 006 & $2,0 \%$ & \\
\hline Instrução & 005 & $1,9 \%$ & $005-1,9 \%$ \\
\hline TOTAL & 270 & $100,0 \%$ & \\
\hline
\end{tabular}

Legenda: S, solidarização com o PDV; R, recusa do PDV. As numerações 1,2 e 3 referem-se aos respectivos fragmentos da coletânea. Assim, $3 S$ é a solidarização com o PDV do terceiro fragmento; 3R é a recusa ao PDV do terceiro fragmento.

Desses resultados, sobressai-se a majoritária valorização positiva do trabalho, com $87,9 \%$ das ocorrências e a alta solidarização com o PDV do terceiro fragmento, com o índice de 59,3\%, isto é, a valorização do trabalho intelectual (de arte). Esses resultados apontam para a valorização de um discurso em que prevalece a valorização do trabalho e, principalmente, a do trabalho intelectual, isto é, aquele que não exige esforço braçal e, por isso, como visto nas análises, como aquele que 
traz prazer. Em outras palavras, repudia-se o trabalho-exploração (16\% das ocorrências), alegando a necessidade de mudanças nas relações de trabalho. $O$ desejo que circula nas discussões sobre o trabalho no mundo contemporâneo é o da necessidade de se trabalhar no que gosta, uma vez que, na sociedade atual, não se pode deixar de trabalhar. Trata-se de um discurso cristalizado e que não reflete as reais necessidades de mudança do poder capitalista, que visa ao lucro incondicionalmente. Considerando que o discurso do vestibulando dirige-se à banca corretora, que avalia a sua criticidade, pode-se dizer que seu discurso era o esperado, isto é, criticar as mazelas do capitalismo que explora o trabalhador, mostrando-se um cidadão consciente. Seu discurso incide sobre uma valorização exacerbada do bem e do belo, visto pelo viés do prazer no/do trabalho, em que o escrevente procura passar a imagem de um bom cidadão, que valoriza o bem, a justiça no trabalho e a necessidade do trabalho-prazer. O escrevente não quer convencer seu interlocutor de algo, mas mostrar que sabe argumentar na redação de vestibular. Ele constrói imagens de si, diante da ficcionalização de seu outro, este, visto como banca corretora que, ao invés de sentir-se convencida por sua argumentação, deve verificar se o vestibulando contempla ou não o requisito de saber construir um texto organizado argumentativamente. Esse aspecto reforça o modo como propus considerar a redação de vestibular em seu funcionamento, isto é, num espaço simbólico mediado por suas três dimensões: a escolar, uma avaliação por meio da escrita; a burocrática, em função da necessidade de cumprir um protocolo para acesso ao ensino superior e a ficcionalizada.

Com o objetivo de expor um panorama geral dos PDVs depreendidos das análises, apresento algumas comparações entre a incidência da valorização (ou não) do trabalho, no diálogo estabelecido com os PDVs, em sua relação com o tipo de ensino médio realizado pelo vestibulando, isto é, em escola particular ou pública, bem como em relação à frequência ou não a cursinho preparatório para o exame vestibular. 
Tabela 12: Comparativo entre os PDVs e tipo de ensino/frequência a cursinho

\begin{tabular}{|c|c|c|c|c|c|c|c|c|c|c|c|}
\hline \multirow{3}{*}{$\begin{array}{l}\text { 山山을 } \\
\text { 을 } \\
\text { 을 }\end{array}$} & \multirow{3}{*}{$\begin{array}{l}\frac{0}{1} \\
\frac{2}{2} \\
\frac{0}{5} \\
0\end{array}$} & \multicolumn{4}{|c|}{$\begin{array}{l}\text { Valorização do } \\
\text { trabalho }\end{array}$} & \multicolumn{4}{|c|}{$\begin{array}{c}\text { Depreciação do } \\
\text { trabalho }\end{array}$} & \multirow{3}{*}{ 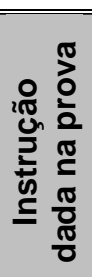 } & \multirow{3}{*}{$\begin{array}{l}\vec{\leftarrow} \\
\stackrel{5}{\circ}\end{array}$} \\
\hline & & \multicolumn{2}{|c|}{$\begin{array}{c}\text { Trabalho } \\
\text { Geral } \\
(+)\end{array}$} & \multirow{2}{*}{$\begin{array}{c}\begin{array}{c}\text { Trabalho } \\
\text { Intelectual } \\
(+)\end{array} \\
3 S\end{array}$} & \multirow{2}{*}{$\begin{array}{l}\vec{\leftarrow} \\
\stackrel{5}{\circ}\end{array}$} & \multicolumn{2}{|c|}{$\begin{array}{c}\text { Trabalho } \\
\text { Geral } \\
(-)\end{array}$} & \multirow{2}{*}{\begin{tabular}{|c|}
$\begin{array}{c}\text { Trabalho } \\
\text { Intelectual } \\
(-)\end{array}$ \\
$3 R$
\end{tabular}} & \multirow{2}{*}{$\begin{array}{l}\vec{\leftarrow} \\
\stackrel{5}{\circ}\end{array}$} & & \\
\hline & & 1S & $2 R$ & & & $1 R$ & $2 S$ & & & & \\
\hline \multirow{2}{*}{$\frac{8}{\frac{0}{2}}$} & 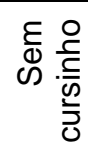 & 2 & 1 & 25 & $10,5 \%$ & 0 & 3 & 2 & $1,9 \%$ & 0 & $\begin{array}{c}12,4 \\
\%\end{array}$ \\
\hline & 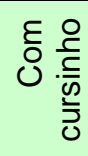 & 9 & 13 & 42 & $24,0 \%$ & 0 & 7 & 0 & $2,6 \%$ & 4 & $\begin{array}{c}28,0 \\
\%\end{array}$ \\
\hline \multirow{2}{*}{$\begin{array}{l}\frac{\bar{c}}{\bar{J}} \\
\overline{\underline{E}} \\
\frac{\bar{E}}{0}\end{array}$} & 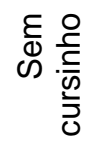 & 8 & 12 & 39 & $22,0 \%$ & 1 & 7 & 2 & $3,7 \%$ & 1 & $\begin{array}{c}26,2 \\
\%\end{array}$ \\
\hline & 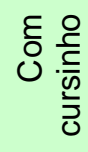 & 13 & 16 & 50 & $29,6 \%$ & 0 & 6 & 2 & $3,0 \%$ & 0 & $\begin{array}{c}32,5 \\
\%\end{array}$ \\
\hline \multirow{2}{*}{ 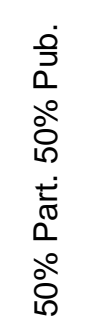 } & 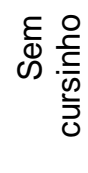 & 0 & 1 & 0 & 0,4 & 0 & 0 & 0 & 0 & 0 & $0,4 \%$ \\
\hline & 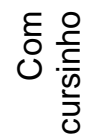 & 0 & 0 & 1 & 0,4 & 0 & 0 & 0 & 0 & 0 & $0,4 \%$ \\
\hline \multirow{2}{*}{\multicolumn{2}{|c|}{ Total }} & 32 & 43 & 157 & 232 & 1 & 23 & 6 & 30 & 5 & 267 \\
\hline & & \multicolumn{3}{|c|}{232} & $(86,9 \%)$ & \multicolumn{3}{|c|}{30} & $11,2 \%$ & $1,9 \%$ & $(100 \%)$ \\
\hline
\end{tabular}

Os resultados apontam para a tendência em valorizar 0 trabalho $\mathrm{e}$ principalmente $\mathrm{o}$ trabalho intelectual (de arte) dentre aqueles que frequentaram cursinho. Se considerarmos a variável tipo de ensino, o percentual aumenta quando se trata de ensino público, sendo maior do que o dobro. Destaca-se o percentual de recusa do PDV do segundo fragmento, que é treze vezes maior entre quem frequentou cursinho. Já no ensino particular, a diferença entre quem frequentou cursinho ou não é menos significativa, sinalizando para a suposição de um ensino mais uniforme da redação de vestibular. Esse resultado reforça o que foi visto nas comparações anteriores, em que a frequência a cursinhos preparatórios, 
principalmente dos candidatos provenientes de escola pública, propicia diferenças significativas nos resultados.

\subsection{A construção do PDVD na redação de vestibular}

A dominância de PDVs pode ser observada a partir das escolhas linguísticas do escrevente. Neste trabalho, ela foi analisada por meio de diferentes modos de qualificação (adjetivação, articulada (ou não) à modalização). Da análise, pode ser depreendido que o discurso do escrevente se fez predominantemente pelo discurso do outro, marcado no texto pelas adjetivações e modalizações. A estrutura do gênero redação de vestibular se fez, em sua maior parte, pelo tom monocórdico de seguir um modelo predeterminado. Entretanto, nas redações em que o escrevente se mostrou mais contundente em seu posicionamento, essa saliência se mostrou efetivamente no seu trabalho com a linguagem, principalmente no que se refere ao modo como se utilizou da qualificação para reforçar o PDV construído, mesmo sendo este, na maioria das vezes, um PDV do senso comum. A qualificação se mostra, efetivamente, como uma estratégia argumentativa. Todo esse trabalho com a linguagem revela o papel das condições de produção do discurso. O escrevente atende às coerções do contexto histórico e social, aos interlocutores, ao gênero, ao manual de instrução, a seus letramentos, às suas representações.

A redação de vestibular, como já dito, se constitui no entremeio de três dimensões: a escolar, a burocrática e a ficcional. A dimensão escolar, uma avaliação por meio da escrita, pode ser depreendida pelas evidências de sua responsividade, ao tentar atender, de diferentes modos, o que era esperado para um vestibulando, isto é, a escrita de um gênero específico, atendendo a todos os requisitos necessários para que sua escrita resultasse na construção desse gênero, respondendo a seus diferentes interlocutores, constituídos por seu destinatário em perfil ampliado: o interlocutor presumido - a banca de corretores -, os critérios de correção da prova, constantes no manual do candidato, os comandos de seus professores, etc. A burocrática, em função da necessidade de cumprir um protocolo para acesso ao ensino superior, por meio de uma situação de enunciação bastante restrita. Já a dimensão ficcionalizada caracteriza-se pelo fato de o escrevente construir imagens de si e do objeto de discurso diante da ficcionalização de seu 
outro. Essa dimensão apresentou-se bem marcada nas redações, como resposta também às coerções sofridas pelo escrevente.

Assim, a construção do PDVD está diretamente relacionada a essas dimensões. A dimensão escolar e a burocrática, sendo altamente institucionalizadas, marcam-se no texto por meio do PDV do destinatário, em que o escrevente responde a um discurso institucional e pedagógico. A dimensão ficcionalizada corresponde à projeção, pelo escrevente, de uma situação representada, da qual ele participa como sujeito legítimo. Essas três dimensões criam um espaço simbólico que dá existência ao gênero redação de vestibular. 


\section{CONSIDERAÇÕES FINAIS}

Neste trabalho, investiguei como se constrói o PDVD no gênero redação de vestibular, apoiando-me numa perspectiva enunciativo-discursiva. $O$ objetivo geral foi identificar os diferentes PDVs presentes no texto e descrever de que modo se constrói o PDVD na organização do texto.

A construção do PDVD se estabelece a partir do diálogo com outros PDVs, tendo em vista algumas estratégias adotadas pelo escrevente.

Uma primeira estratégia é a escolha dos PDVs a partir das fontes diretas de que o escrevente dispõe: a coletânea e a instrução fornecidas pela prova. Essa estratégia se realiza de duas maneiras. A primeira maneira se caracteriza pelo fato de que o escrevente toma os textos da coletânea/instrução como perguntas e responde a elas já no modo de estruturar sua redação, nela mantendo a mesma ordem de apresentação dos textos dessa fonte ou optando pela escolha de um fragmento privilegiado. Ligada a essa maneira, mas constituindo-se numa sua variante, a opção pelo PDV pode vincular-se não à leitura da distribuição espacial dos textos da coletânea, mas a algum PDV saliente para o vestibulando. Neste caso, a escolha do primeiro fragmento da coletânea pode dar-se, por exemplo, não porque está mais a mão, mas porque apresenta definições do que seja o trabalho, o que sugere não só um PDV, mas também uma solução para a estruturação do texto, a saber, definir o tema, comentar e contrapor várias definições. Em quaisquer de seus dois modos de realização, nessa estratégia, destaca-se o modo majoritário como o terceiro fragmento foi privilegiado na qualificação positiva dada pela construção do PDVD. Além disso, evidencia-se a relação entre o modo de escrever do vestibulando e o seu modo de ler e interpretar os textos fornecidos pela prova.

A segunda estratégia é a construção de PDVs em sua relação com as diferentes representações sociais aplicadas à coletânea. Os resultados revelaram que as representações sociais do escrevente sobre o trabalho, sobre a universidade e sobre os saberes provenientes de outras esferas tinham em comum a majoritária preocupação com a valorização positiva do trabalho e, principalmente, do trabalho intelectual. A qualificação teve papel importante na construção desses PDVs, e se 
apresentou de diferentes maneiras: (a) pelo tom conceitual, norteou a construção do PDVD pelo privilégio dado ao primeiro fragmento que, após a descrição do que é o trabalho, firma-se um PDV que o valoriza (e o eterniza), dada sua suposta importância para a humanidade; (b) pelo tom deôntico, explicitado na construção do PDV da necessidade do trabalho para o sustento da humanidade; (c) pelo tom denunciatório, que permite vislumbrar a imagem de um sujeito consciente das injustiças sociais; (d) pelo tom eufórico com que é valorizada a universidade e o que ela representa para o vestibulando (nesse tom eufórico, há, também, espaço para a valorização da educação); (e) pelo tom de autoridade, que se concretiza na mobilização de saberes de diferentes esferas sociais, saberes reconhecidos pelo vestibulando como pleno de valores.

Nessas diferentes maneiras de construir PDVs, pode-se observar 0 comportamento do vestibulando que, por meio do uso da qualificação - altamente avaliativas e axiologizadas - na constituição desses diferentes tons, reforça determinados valores em relação ao trabalho e ao trabalho intelectual, à universidade, à educação, etc. Destaco o diálogo com a esfera histórica, em que, do cruzamento desses diferentes PDVs, vislumbra-se o efeito polifônico da construção do PDVD.

Foi observada também, a construção do PDVD a partir da comparação entre os resultados obtidos e duas variáveis tomadas do questionário respondido pelo vestibulando: o tipo de ensino médio cursado, isto é, público ou particular e a frequência ou não a cursinho preparatório para o exame vestibular. Destaco dessa observação a influência da variável frequência a cursinho, em que, nas escolas públicas, resultaram em respostas diferentes entre os vestibulandos que frequentaram algum tipo de curso preparatório no que se refere à construção do PDVD. Os resultados apontaram para a tendência em valorizar positivamente 0 trabalho e principalmente o trabalho intelectual (de arte). Essa mesma valorização se repetiu no diálogo com os PDVs da coletânea, em que o vestibulando apoia a estrutura de sua redação na mesma ordem de aparecimento dos textos da coletânea. Essa variável se mostrou bem menos significativa quando se tratou de escolas particulares.

Considerando o objetivo geral da pesquisa, bem como os objetivos específicos e os resultados obtidos, concluo que a construção do PDVD só é 
possível na correlação dialógica com outros PDVs. A coletânea, fonte imediata disponível para o escrevente, serve como recurso principal para a busca de PDVs. $O$ recurso à mobilização de saberes de esferas diferentes das da coletânea fortaleceu o efeito polifônico da construção do PDVD. Desse efeito polifônico, ressalto os movimentos de desdobramentos dos PDVs retomados pelo escrevente para construir o PDVD:

1) aquele em que o escrevente apenas reafirma os PDVs mobilizados se solidarizando (S) com eles, nesse caso, ele coenunia com esses mesmos PDVs;

2) aquele em que o escrevente se distancia dos PDVs mobilizados, refutandoos (R), para construir outros PDVs. Ao refutá-los ele subenuncia esses PDVs; e

3) aquele em que o escrevente mobiliza outros PDVs assumindo-os ou não, para construir outro PDV que é sobreposto aos demais PDVs, isto é, ele sobreenuncia para construir o PDVD na correlação com os PDVs mobilizados.

Destaco, desses movimentos, aqueles que direcionaram a argumentação para a constituição do PDVD, em que prevalece a valorização do trabalho e, principalmente, a do trabalho intelectual, com $87,9 \%$ da totalidade do corpus. A redação de vestibular, em seu caráter altamente responsivo, funciona como uma prática discursiva da escrita. Os diferentes modos de qualificação observados na análise permitiram observar a manifestação de um sujeito que se posiciona na construção do PDVD, diante das possibilidades de relações dialógicas abertas com outros PDVs.

A redação de vestibular se constitui no entremeio de três dimensões: a escolar, a burocrática e a ficcional. Em virtude da sua função social de, juntamente com a das demais provas do exame vestibular, permitir ao vestibulando o acesso ao ensino superior, merecem destaque os resultados que apontaram para a ficcionalização do gênero redação de vestibular. Esse caráter de ficcionalização apresentou-se bem marcado nas redações, como resposta às coerções sofridas pelo escrevente, que constrói diferentes representações ao escrever seu texto.

Considerando as hipóteses iniciais, concluo que o escrevente constrói o PDVD e demarca sua defesa por meio do uso de diferentes modos de qualificar, utilizando-os como estratégias para a construção do PDVD na organização do texto e sustentando sua posição quanto ao tema na relação dialógica com outros PDVs. 
No que se refere à mobilização de saberes: (a) o escrevente, para sustentar seu posicionamento, mobiliza seus saberes e os utiliza como uma das estratégias para a construção do PDVD; e (b) os diferentes modos de mobilizar saberes são constitutivos do gênero discursivo analisado, e moldados pelas representações de escrita, do acontecimento - o evento vestibular -, da imagem sobre si e do outro seu interlocutor -, bem como pelas práticas letradas do candidato, incluindo nestas, o modo como lê e interpreta os enunciados da prova de redação.

Por sua vez, essa construção orienta-se por dois aspectos: (a) o da leitura que o escrevente faz da coletânea fornecida pela prova e, mediado por ela, o aproveitamento dos fatos históricos nela referidos ou a partir dela inferidos e (b) o de como o escrevente sustenta esse julgamento, a fim de marcar efetivamente seu posicionamento. Desse modo, a perspectiva enunciativa contribui para depreender os diferentes PDVs que se constituíram a partir de elementos qualificadores, vistos como estratégias argumentativas; a perspectiva discursiva permitiu desdobrar discursivamente essas estratégias, que resultaram em efeitos polifônicos na construção do PDVD.

A explicitação da construção do PDVD na organização do texto pode contribuir para a melhoria da qualidade do ensino de língua materna e da escrita, em particular, no sentido de se considerar que, por exemplo, as estratégias discursivas construídas a partir de elementos qualificadores podem ser vistas como marcas dialógicas que respondem às representações sociais do escrevente, tendo em vista a construção de PDVs.

Elas podem resultar em efeitos interessantes no ensino da escrita, diante da possibilidade da leitura de diferentes textos, tomados em seus aspectos textuais, enunciativos e discursivos, deixando de lado o treino mecânico de estruturas desconexas das dimensões do gênero. Os elementos qualificadores deixariam, assim, de ser considerados, numa visão mais tradicional e descritiva de ensino da escrita, simplesmente como uma classe gramatical, para serem concebidos em sua dimensão discursiva. Nesse sentido, ganha-se espaço para o ensino da escrita a partir de sua dimensão dialógica, isto é, como prática social inserida no processo sócio-histórico. Além disso, este estudo pode também contribuir para a reflexão sobre conceito outro de história: não mais cronologia e passagem do tempo, mas como discurso. 


\section{Referências Bibliográficas}

ADAM, Jean-Michel. Les texts: types et prototypes, recit, description, argumentation, explication et dialogue. Paris: Nathan,1992.

. L'argumentation publicitaire [Texte imprimé]: rhétorique de l'éloge et de la persuasion, Paris: Armand Colin, 1ํvol., DL 2007.

ALTHUSSER, Louis. Ideologia e aparelhos ideológicos de estado. Tradução de Joaquim José de Moura Ramos, 3ª . Ed., Lisboa: Presença, 1980.

Aparelhos ideológicos de estado: notas sobre os aparelhos ideológicos de estado. Tradução de José Augusto G. Albuquerque; Walter J. Evangelista; Maria Laura. V de Castro. 3르. Ed., Rio de Janeiro: Graal, 1985.

AMARAL, Emilia; ANTONIO, Severino; PATROCÍNIO, Mauro Ferreira do. Manual Nova Cultural: redação, gramática, literatura, interpretação de texto. São Paulo: Nova Cultural, 1991.

AMOSSY, Rute. L'argumentation dans le discours. $2^{a}$. Ed. Paris: Armand Colin, 2006 [2002]. $2005 a$.

. Imagens de si no discurso: a construção do ethos. São Paulo: Contexto,

. "De l'apport d'une distinction: dialogisme vs polyphonie dans l'analyse argumentative". In: BRES, Jacques et al. COLLOQUE DE CERISY, 2004, Cerisy-la Salle, Dialogisme, polyphonie: approches linguistiques, Bruxelles: Duculot, 2005b.

e PIERROT, Anne Herschberg. Stéréotypes et clichés: langue, discours, societé. Paris : Armand Colin, 2007.

ANSCOMBRE, Jean-Claude et DUCROT, Oswald. L'Argumentation dans la langue. Bruxelles. Liège: P. Mardaga, 1983.

ARIMA, Jeanete Akemi. Requisitos para leitura do enunciado da prova de redação de vestibulares. Dissertação de Mestrado. Taubaté-SP: UNITAU, 2008.

AUTHIER-REVUZ, Jaqueline. "Heterogeneidade(s) enunciativa(s)". In: Caderno de estudos linguísticos. Campinas-SP, v. 19, p. 25-42, 1990.

. "Palavras mantidas a distância". In: AUTHIER-REVUZ, Jacqueline. Entre a transparência e a opacidade: um estudo enunciativo do sentido. Trad. Heloisa Monteiro Rosário. Porto Alegre: EDIPUCRS, p. 217- 37, 2004 [1982].

BAGNO, Marcos. Dramática da língua portuguesa. São Paulo: Parábola Editorial, 2000.

BAKHTIN, Mikhail. Marxismo e filosofia da linguagem. São Paulo: Hucitec, 1986 [1929]. 
. "Os gêneros do discurso". In: Estética da criação verbal. São Paulo:

Martins Fontes, p. 279-326, 1992 [1979].

. "Os gêneros do discurso". In: Estética da criação verbal. São Paulo:

Martins Fontes, p. 261-306, 2003 [1979].

. Problemas da poética de Dostoiévsk. 4를 Edição. Rio de Janeiro: Forense Universitária, 2008.

Bally, Charles. Traité de stylistique française. Paris, Klincksieck, 1951.

. Linguistique générale et linguistique française. 4를 Edição. Berne:

Francke, 1965.

BARROS, Diana Luz Pessoa. A festa do discurso: teoria do discurso e análise de redações de vestibulandos. Tese de livre docência em Linguística, Departamento de Linguística e Línguas Orientais da FFLCH-USP, 1985.

BEAUGRANDE, Robert-Alain de; DRESSLER, Wolfgang U. Introduction to text linguistic. Londres: Longman, 1988.

BENVENISTE, Émile. Problemas de Linguística Geral I. Campinas-SP: Pontes/ Ed da Unicamp, 1989.

1989.

. Problemas de Linguística Geral II. Campinas-SP: Pontes/ Ed da Unicamp,

BEZERRA, Paulo. "Polifonia". In: BRAIT, Beth (org.). Bakhtin: conceitos-chaves. 4" Ed., São Paulo: Contexto, 2007.

$\mathrm{BOCH}$, Françoise; LABORDE-MILAA, Isabelle; REUTER, Yves. Les écrits universitaires. Metz: Cresef, 2004.

BOURDIEU, Pierre. Economia das trocas linguísticas: o que falar quer dizer. São Paulo: EDUSP, 1996.

. Sociologia. Organizador da coletânea Renato Ortiz. Tradução de Paula Monteiro e Alicia Auzmendi. São Paulo: Ática, 1983.

. Coisas ditas. Trad. Cássia R. da Silveira e Denise Moreno Pegorim. São

Paulo: Brasiliense, 2004.

BRAIT, Beth. Ironia em perspectiva polifônica. Campinas-SP, Editora da UNICAMP, 2008.

BRANDÃO, Helena Hathsue Nagamine. Introdução à Análise do Discurso. Campinas-SP: Editora da UNICAMP, 1997.

BRASIL. Ministério da Educação e do Desporto. Parâmetros Curriculares Nacionais: ensino médio - língua portuguesa. Brasília: MEC/SEF, 1998. 
BRASIL. Ministério da Educação e do Desporto. Lei de Diretrizes e Bases da Educação Nacional. oㅜ 5692, de 11 de agosto de 1971. Diário Oficial. Brasília: MEC 1971. Disponível em < http://www.planalto.gov.br/ccivil_03/Leis/L5692.htm>, último acesso em 19.12.2008.

BRASIL. Ministério da Educação e do Desporto. Lei de Diretrizes e Bases da Educação Nacional. o 9394, de 20 de dezembro de 1996. Diário Oficial. Brasília: MEC 1996. Disponível em <http://www.planalto.gov.br/ccivil 03/Leis/L9394.htm>, último acesso em 19.12.2008.

BRASIL. Ministério da Educação e do Desporto. Decreto ํㅜㄱ‥298, de 24 de fevereiro de 1977. Brasília MEC 1977.

BRASIL. Ministério da Educação e do Desporto. Portaria no 391/2002 de 07 de fevereiro de 2002. Brasília MEC, 2002.

BRES, Jacques e VERINE, Bertrand. "Le bruissement des voix dans le discours: dialogisme et discours rapporté", In: ROSIER, Laurence. Faits de langue, 19 - Le discours rapporté, Paris: Orphrys, p. 159 -169, 2002.

BUIN, Edilaine. A construção da coerência textual em situações de ensino. Tese de doutorado, Campinas-SP: UNICAMP, 2006.

. "A construção de sentido em textos escolares: entre versões e mediações." In: SIGNORINI, Inês. (org.) Significados da inovação no ensino de língua portuguesa. ${ }^{\text {a }}$ Ed. Campinas-SP: Mercado das Letras, 2007, p.47-77.

BUNZEN Junior, Clecio dos Santos. Livro didático de língua portuguesa: um gênero do discurso. Dissertação de Mestrado, Campinas-SP: UNICAMP, 2005.

BUSSE, Sanimar. "Uma análise da heterogeneidade discursiva em redações produzidas por vestibulandos". Revista Línguas e Letras. Dossiê: um olhar na ciência linguística. v. 7, № 12, p. 49-63 - 1ํsem. 2006.

CANDIDO, Antonio. "O mundo-provérbio". In: CANDIDO, Antonio. 0 discurso e a cidade. 3를 Ed. São Paulo/Rio de Janeiro: Duas cidades/Ouro Azul, 2004.

CARONE, Flávia de Barros. "O desempenho linguístico dos candidatos ao vestibular: concordância verbal". Cadernos de Pesquisa da Fundação Carlos Chagas, São Paulo, № 19, 39-52, 1976.

CASTILHO, Ataliba. T. "Advérbios qualificadores no português falado". In: Boletín de Filologia. Tomo XXXVII. v. 1, p. 271-300. Santiago: La Facultad, 1999.

CASTILHO, Ataliba. T.; CASTILHO, Célia. "Advérbios modalizadores". In: ILARI, Rodolfo (org.) Gramática do português falado. Vol II. $4^{a} \mathrm{Ed}$. Rev. Campinas-SP: Unicamp, 2002.

CERVONI, Jean. A enunciação. São Paulo: Ática, 1989.

CHACON, Lourenço. Ritmo da escrita: uma organização do heterogêneo da linguagem. São Paulo: Martins Fontes, 1998. 
CHARANDEAU, Patrick; MAINGUENEAU, Domenique. Dicionário de análise do discurso. 2ª Edição. São Paulo: Contexto, 2006.

CHAUÍ, Marilena. "Introdução". In: LAFARGUE, Paul. $O$ direito à preguiça. Tradução de J. Teixeira Coelho Netto; introdução de Marilena Chauí. São Paulo: Hucitec: Unesp, pp. 9-56, 1999.

. O que é ideologia. São Paulo: Brasiliense, 2001.

CITELLI, Adilson. O texto argumentativo. São Paulo: Scipione, 1994.

CONCEIÇÃO, Rute Izabel Simões Conceição. "Da redação escolar ao discurso: um caminho a (re)construir”. Linguagem \& Ensino, Vol. 3, № 2, pp. 109-133, jul 2000.

Disponível em $<$ http://rle.ucpel.tche.br/php/edicoes/v3n2/H Conceicao.pdf>., acessado em novembro/2008.

COMVEST. Prova comentada - redação, 2011. Disponível em http://www.comvest.unicamp.br/vest anteriores/2012/download/comentadas/redacao .pdf.

CORRÊA, Manoel Luiz Gonçalves. "Letramento e heterogeneidade da escrita no ensino de português.". In: MARCUSCHI, Luiz Antonio... [et al]; SIGNORINI, Inês (Org.). Investigando a relação oral/escrito e as teorias do letramento. CampinasSP: Mercado de Letras, 2001.

Fontes, 2004.

O modo heterogêneo de constituição da escrita. São Paulo: Martins

. "Heterogeneidade da escrita: a novidade da adequação e a experiência do acontecimento". In: Filologia e linguística portuguesa, vol. 8, São Paulo: Humanitas, 2006, pp. 269-286.

. Encontros entre prática e pesquisa de ensino: Oralidade e letramento no

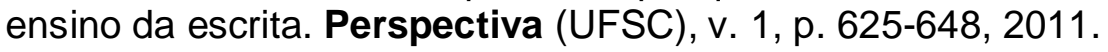

COSTA VAL, Maria da Graça. Redação e textualidade. 3ª Edição. São Paulo: Martins Fontes, 2006 [1983].

DELCAMBRE, I., (1990), "De l'argumentation à la dissertation. Analyse d'une démarche d'apprentissage". In: La dissertation. Pratiques, 68, p. 69-88. Metz: CRESEF, dez. 1990.

DIONÍSIO, Angela; HOFFNAGEL, Judith (orgs.). Gêneros textuais, tipificação e interação. São Paulo: Cortez, 2005.

DISCINI, Norma. A comunicação nos textos. São Paulo: Contexto, 2005.

DOLZ, Joaquim; SCHNEUWLY, Bernard; "Gêneros e progressão em expressão oral e escrita - elementos para reflexões sobre uma experiência suíça (francófona)". In ROJO, Roxane; CORDEIRO, Glaís Sales (Trad. e org.). Gêneros orais e escritos na escola. Tradução Roxane Rojo e Glaís Sales Cordeiro. Campinas-SP: Mercado de Letras, 2004, p. 41-70. 
DUBOIS, Jean. Dicionário de linguística. $8^{a}$ Edição. Supervisão da tradução Izidoro Blikstein. São Paulo: Cultrix, 2007.

DUCROT, Oswald. Les échelles argumentatives. Paris: Minuit, 1980.

O dizer e o dito. Campinas: Pontes, 1987.

1972.

. Dire et ne pas dire: principes de sémantique linguistique. Paris: Hermann,

DUFAYS, Jean-Louis. Stéréotype et lecture. Liège: P. Mardaga, cop. 1994.

DUTRA, Vania. A redação escolar e a redação de vestibular como gêneros textuais. In: SIMÕES, Darcília (Org.). Língua portuguesa. Ensino, pesquisa, pósgraduação e formação docente. Rio de Janeiro: Dialogartes, 2008, pp. 25-48.

FÁVERO. Maria de Lourdes de Albuquerque. "A universidade no Brasil: das origens à reforma universitária de 1968”. Educar, n 28, p. 17-136, Curitiba: Editora UFPR, 2006. Disponível em < http://ojs.c3sl.ufpr.br/ojs2/index.php/educar/article/view/ 7609/ $5423>$

FÁVERO, Leonor Lopes; $\mathrm{KOCH}$, Ingedore Grunfeld Villaça. Linguística textual: introdução. São Paulo: Cortez, 1983.

FERNANDES, Florestan. "O folclore de uma cidade em mudança". In: FERNANDES, Florestan. Folclores e mudança social na cidade de São Paulo. $2^{\mathrm{a}}$ Ed. Petrópolis: Vozes, 1979.

FERNANDES, Maria do Socorro Nóbrega,. "O desempenho linguístico dos candidatos ao vestibular: distribuição dos demonstrativos". Cadernos de Pesquisa da Fundação Carlos Chagas, São Paulo, no 19, 53-74, 1976.

FíGARO, Roseli Aparecida. "O mundo do trabalho e as organizações: abordagens discursivas de diferentes significados". In: Organicom. São Paulo: ECA/USP, v. 9, $2^{\circ}$ sem, 2008, pp.90-100.

FIORIN, José Luiz. As Astúcias da Enunciação: categorias de pessoa, espaço e tempo, $2^{\mathrm{a}}$ Ed., São Paulo: Ática, 1999.

. Linguagem e ideologia. $7^{a}$ Ed. São Paulo: Ática, 2002a.

. Introdução à linguística I: objetos teóricos. São Paulo: Contexto, 2002b.

. "Polifonia textual e discursiva". In: BARROS, Diana L. Pessoa; FIORIN, José Luiz (orgs.). Dialogismo, polifonia, intertextualidade: em torno de Bakhtin. $2^{\mathrm{a}}$ Ed., São Paulo: Editora da Universidade de São Paulo, 2003.

FREIRES, Fátima Neide (2002) Quando a premissa é persuadir: a argumentação pela interlocução. Dissertação de Mestrado, Campinas-SP: IEL-UNICAMP, 2002

FRIER, Cathy; et BOCH, Françoise (coord). Pratiques de lecture et d'écriture: des usages sociaux aux savoirs scolaires. Grenoble: Université Stendhal: Lidilem, 2002. 
FOUCAULT, Michel. O que é um autor? Tradução de Antonio F. Cascais e Edmundo Cordeiro, Vega: Passagens, 1992.

FUVEST. Manual do Candidato, 2006.

GATTI, Bernadete A. "Vestibular e ensino superior nos anos 70 e 80 " In: Cadernos de Pesquisa da Fundação Carlos Chagas. № 80, p. 87-90, fevereiro de 1992.

GENETTE, Gérard. Figures III. Paris: Seuil, 1972.

GERALDI, Wanderley. Portos de Passagem. São Paulo: Martins Fontes, 1997. . (org.). O texto na sala de aula: leitura \& produção. São Paulo: Ática, 1999.

GRANATIC, Branca. Técnicas básicas de redação. São Paulo: Scipione, 1999.

GRATALOUP, Nicole, "La philosophie à l'épreuve de la dissertation". Pratiques no 68, dezembro 1990.

HANKS, William F. Língua como prática social: das relações entre língua, cultura e sociedade a partir de Bourdieu e Bakhtin; organização BENTES, Anna Cristina; et.al., São Paulo: Cortez, 2008.

HOUAISS, Antonio; VILLAR, Mauro de Salles. Dicionário eletrônico Houaiss da Língua Portuguesa. Rio de Janeiro: Objetiva, 2002, CD-rom versão 1.0, para Windows.

ILARI, Rodolfo. A linguística e o ensino da língua portuguesa. São Paulo: Martins Fontes, 1997.

KERBRAT-ORECCHIONI, Catherine. L'énonciation: de la subjectivité dans le langage. Paris: Armand Colin, 1980. Colin, 2002.

. L'énonciation: de la subjectivité dans le langage. 4a . Ed. Paris: Armand

KLEIMAN, Ângela. Os significados do letramento: uma nova perspectiva sobre a prática social da escrita. Campinas-SP: Mercado de Letras, 1995.

$\mathrm{KOCH}$, Ingedore Grunfeld Villaça. A inter-ação pela linguagem. 4ª Ed. São Paulo: Contexto, 1998.

Argumentação e linguagem. 5aㅡ Ed., São Paulo: Cortez, 1999.

LEMOS, Cláudia T. Guimarães. "Redações no vestibular: algumas estratégias". In: Cadernos de Pesquisa da Fundação Carlos Chagas. oㅡ 23, p. 61-71, dezembro de 1977, disponível em:

$<$ http://www.fcc.org.br/pesquisa/actions. actionsEdicoes.BuscaDetalhada.do?tp_cade rno $=0 \&$ order $=0 \&$ tp_busca $=2 \&$ detalhe $=23>$

LINO DE ARAÚJO, Denise. "Práticas letradas no vestibular: análise de uma prova de redação". In: Revista Intercâmbio, v. 15, São Paulo: LAEL/PUC, 2006. 
LOHRER, Magda Branco. A coesão e a coerência em função da persuasão em texto dissertativo-argumentativo: uma abordagem sistêmico-funcional. Tese de Doutorado, São Paulo: PUC, 2009.

MAINGUENEAU, Domenique. L'analyse du discours: introduction aux lectures de l'archive. Paris: Hachette, 1991.

Novas tendências em análise do discurso. Trad. Freda Indursky, $2^{\mathrm{a}} \mathrm{Ed}$. Campinas-SP: Pontes, 1993.

. Termos chaves da análise do discurso. Tradução Márcio Venício Barbosa, Maria Emília Amarante Torres Lima, Belo Horizonte: UFMG, 1998.

. Análise de textos de comunicação. São Paulo: Cortez, 1998.

Colin, 2004.

Le discours littéraire: paratopie et scène d'énonciation. Paris: Armand

. "Ethos, cenografia, incorporação". In: AMOSSY, Ruth (org.). Imagens de si no discurso: a construção do ethos. São Paulo: Contexto, 2005.

. Cenas da enunciação. São Paulo: Parábola Editorial, 2008a.

Gênese dos discursos. São Paulo: Parábola Editorial, 2008b.

Doze conceitos em análise do discurso. Organização: Sírio Possenti; Maria Cecília Perez de Souza-e-Silva. Tradução: Adail Sobrel et.al. São Paulo: Parábola Editorial, 2010.

MARCUSCHI, Luiz Antonio. "Gêneros textuais: definição e funcionalidade" In: DIONÍSIO, A. et al. Gêneros textuais e ensino. Rio de Janeiro: Lucerna, 2002.

MARCUSCHI, ELIZABETH. As categorias de avaliação da produção textual no discurso do professor. Tese de doutorado. Recife: UFPE, 2004.

MARQUES, José Geraldo. A redação no vestibular: o uso da coletânea e a intertextualidade. Dissertação de mestrado. Campinas-SP: UNICAMP, 1997.

MARTINS, Nilce Sant'Anna. Introdução à estilística: a expressividade na língua portuguesa. 3를 Edição. São Paulo: T. A. Queiroz, 2000.

MOESCHLER, Jacques. Argumentation et Conversation. Éléments pour une analyse pragmatique du discours. Paris: Hatier-Credif, 1985.

MOIRAND, Sophie. "Quelles catégories descriptives pour la mise au jour des genres du discours ? "In: KERBRAT-ORECCHIONI, Catherine ; TRAVERSO, Véronique (org.). Contributions à la journée 'Les genres de l'oral', organisée par Catherine Kerbrat-Orecchioni et Véronique Traverso, Université Lumière Lyon, Campus Porte des Alpes, 2003. Disponível em http://icar.univ-lyon2.fr/Equipe1/actes/journees genre.htm. Último acesso em agosto de 2011. 
MOSCA, Lineide do Lago Salvador. Subjetividade no editorial: uma análise retórico-argumentativa da adjetivação. Tese de Doutorado. São Paulo: USP-FFLCH, 1991.

NEGRÃO, "Redações no vestibular: utilização do léxico: estudo dos adjetivos". In: Cadernos de Pesquisa Fundação Carlos Chagas, São Paulo, №. 23, p. 9-15, dez. 1977.

NETTO, A. Ribeiro. "O vestibular no sistema educacional brasileiro". In: Cadernos de Pesquisa Fundação Carlos Chagas, São Paulo, №. 24, p. 47-51, mar. 1978.

NEVES, Maria Helena de Moura. Gramática de usos do português. São Paulo: UNESP, 2000.

. Texto e gramática. São Paulo: Contexto, 2007.

NORÉN, Coco. "L'argumentation par autorité dans les répliques de Madame Bovary”. In: OLSEN, M. Polyphonie - linguistique et littéraire I. Roskilde: Roskilde Samfundslitteratur, 2000, pp. 31-52.

NOWAKOWSKA, Aleksandra. "Dialogisme, polyphonie: des textes russes de M. Bakhtine à la linguistique contemporaine". In: BRES, Jacques et al. COLLOQUE DE CERISY, 2004, Cerisy-la Salle, Dialogisme, polyphonie: approches linguistiques. Bruxelles: Duculot, 2005.

OLIVEIRA, Helênio Fonseca de. "Os gêneros da redação escolar e o compromisso com a variedade padrão da língua". In: HENRIQUES, Claudio Cezar; SIMÕES, Darcilia (orgs.). Língua e cidadania: novas perspectivas para o ensino. Rio de Janeiro: Europa, 2004.

OSAKABE, Haquira. "Redações no vestibular: provas de argumentação". In: Cadernos de Pesquisa da Fundação Carlos Chagas, São Paulo, ํo 23, p. 51-9, dez. 1977.

PACHECO, Agnelo de Carvalho. A dissertação. São Paulo: Atual, 1988.

PAVANI, Cinara Ferreira; KÖCHE, Vanilda Salton; BOFF, Odete Maria Benetti, "Redação de vestibular: gênero heterogêneo". In: Revista Virtual de Estudos da Linguagem - ReVEL. v. 4, n. 6, março de 2006.

PÊCHEUX. Michel. Análise automática do discurso. In: GADET, Françoise; HAK, Tony. (orgs.) Por uma análise automática do discurso: uma introdução à obra de Michel Pêcheux. Campinas-SP: Editora da Unicamp, p. 61-162, 1990a.

A propósito da análise automática do discurso: atualização e perspectivas. In: GADET, Françoise; HAK, Tony. (orgs.) Por uma análise automática do discurso: uma introdução à obra de Michel Pêcheux. Campinas-SP: Editora da Unicamp, p. 163-252, 1990b. 
. "A análise de discurso: três épocas (1983)". In: GADET, Françoise; HAK, Tony. (orgs.). Por uma análise automática do discurso. Uma introdução à obra de Michel Pêcheux. Campinas-SP: UNICAMP, 1990c.

. Semântica e discurso: uma crítica à afirmação do óbvio. Trad. Eni P. Orlandi [et al]. 3ª Ed. Campinas-SP: Editora da UNICAMP, 1997.

. "Papel da memória". In: ACHARD, P.; et al. Papel da memória. CampinasSP: Pontes, 1999.

2002.

. O discurso: estrutura ou acontecimento. $3^{\text {a }}$ Ed. Campinas, SP: Pontes,

PÉCORA, Alcir. "Redações no vestibular: estudo do período, uma proposta

pragmática”. In: Cadernos de Pesquisa da Fundação Carlos Chagas, São Paulo, no 23, p. 29-36, 1977.

. Problemas de redação. São Paulo: Martins Fontes, 1999: 1983.

PERELMAN, Chaïm. Retóricas. Trad. Maria Ermantina de Almeida Prado Galvão. 2 $2^{a}$ Ed., São Paulo: Martins Fontes, 2004.

PERELMAN, Chaïm \& OLBRECHTS-TYTECA, Lucie. Tratado da argumentação. Trad. Maria Ermantina de Almeida Prado Galvão. 2ª Ed., São Paulo: Martins Fontes, 2005.

PERINI, Mário. A. "O adjetivo e o ornitorrinco (Dilemas da classificação de palavras). In: PERINI, Mário A.. Sofrendo a gramática. Ensaios sobre a linguagem. 3a Edição. São Paulo: Ática, 2000.

PETRONI, Maria Rosa. Produção do texto argumentativo escrito: aspectos linguísticos e discursivos. Tese de Doutorado. São Paulo: USP, 2002.

PILAR, Jandira Aquino. "A redação de vestibular como gênero: In: MEURER, José Luiz.; MOTTA-ROTH, Désireé. (orgs.). Gêneros textuais. Bauru-SP: Edusc, 2002.

POSSENTI, Sírio. Discurso, estilo e subjetividade. $2^{\mathrm{a}}$ ed., São Paulo: Martins Fontes, 2001.

RABATEL, Alain. Une histoire du point de vue, recherches textuelles, 2. Metz: Université de Metz, 1997.

Niestle, 1998.

La construction textuelle du point de vue. Lausanne, Paris: Delachaux et . "Un, deux, trois points de vue? Pour une approche unifiante des points de vue narratifs et discursif". In: La lecture littéraire, no 4, pp. 195-254. Paris: Klinckiek / Université de Reims, 2000.

. "Pour une narratologie énonciative, ou pour une approche énonciatie de la narration". In: Vox poetica, 2003, disponível em <http://www.vox-

poetica.org/index.htm>, último acesso em agosto 2009. 
. 'L'effacement énonciatif dans les discours rapportés et ses effets pragmatiques". In: Langages, 156, Paris, Larousse, 2004a, pp. 3-17.

. "Stratégies d'effacement énonciatif et posture de surénonciation dans le Dictionnaire Philosophique de Comte-Sponville". In: Langages, 156, Paris: Larousse, 2004b, pp. 18-33.

. "Les postures énonciatives dans la co-construction dialogique des points de vue: coénonciation, surénonciation, sousénonciation”. In: BRES, Jacques. et al. COLLOQUE DE CERISY, 2004, Cerisy-la Salle, Dialogisme, polyphonie: approches linguistiques, Bruxelles: Duculot, 2005a, pp. 95-110

. "La part de l'énonciateur dans la construction interactionnelle des points de vue". In: Marges linguistiques, Numéro 9, Mai 2005b, disponível em: http://www.marges-linguistiques.com

ROCCO, Maria Thereza. Crise na linguagem: a redação no vestibular. São Paulo: Mestre Jou, 1981.

ROCHA, Regina. A enunciação dos provérbios: descrições em francês e português. São Paulo: Annablume, 1995.

RODRIGUES, Ada Natal. "Redações no vestibular: apresentação". In: Cadernos de Pesquisa Fundação Carlos Chagas, São Paulo, nº. 23, p. 5-6, dez. 1977.

ROJO, Roxane; CORDEIRO, Glaís Sales (org.). Gêneros orais e escritos na escola. Tradução Roxane Rojo e Glaís Sales Cordeiro. Campinas: Mercado de Letras, 2004.

ROUSSELET-FERRANDO, Sylvie. Ethique et Esthétique dans le langage: approche de l'adjectif gradable par sa polarité et son énonciation en français et en anglais. Tese de Doutorado. Paris: Paris IV-Sorbonne (Ecole doctorale Concepts et Langages), 2005.

SAMARA, Eni de Mesquita. 30 anos de FUVEST: a história do vestibular da Universidade de São Paulo, 1976-2006, São Paulo: EDUSP, 2007.

SANTAELLA, Lúcia. Matrizes da linguagem e pensamento: sonora, visual, verbal: aplicações na hipermídia. São Paulo: lluminuras/FAPESP, 2005.

SEELAENDER, Ana Luisa. O uso da sinonímia entre alunos egressos do Ensino Médio. Relatório final de pesquisa. São Paulo: USP-FFLCH, 2008.

SILVA, Elizabeth Maria da. Histórico de letramento e práticas letradas em redações de vestibular. Dissertação de Mestrado. Campina Grande: UFCG, 2009.

SILVA, Elizabeth Maria da; LINO DE ARAÚJO, Denise. "Redação e/ou gêneros textuais: caminhos de produção de textos no vestibular e no ensino médio". In: Anais da Jornada Nacional de Estudos Linguístico do Nordeste, 21. João Pessoa: UFPB, 2006a, p. 35-43. 
. "Redação no vestibular e no ensino médio: um estudo sobre efeito retroativo". In: Anais do Congresso de Iniciação Científica. 3. Campina Grande-PB: UFPB, 2006b. p. 34-44.

. "Relato de experiência no vestibular da UFCG 2005: um estudo sobre as práticas de uso da escrita". In: Anais da XIII Semana de Letras da UEPB: linguagens, tecnologia e ensino: a palavra (re)escrita e (re)lida, 13, Campina Grande-PB: UEPB, 2006c.

. "Redação no vestibular: efeito retroativo da noção de gêneros textuais". In: Trabalho de linguística aplicada, v. 48, São Paulo-Campinas, jan/jun, 2009a, pp.133-152.

. "O gênero memória na redação de vestibular: influência de letramentos." In: Instrumentos - Revista Est. Pesq. Educ. Juiz de Fora, v. 11, n.2, jul/dez, 2009b.

SOARES, Magda Becker. "A redação na vestibular". In: Cadernos de Pesquisada Fundação Carlos Chagas. n‥ 24, p. 53-56, mar. 1978.

. Letramento: um tema em três gêneros. Belo Horizonte: Autêntica, 2001.

. "Novas práticas de leitura e escrita: letramento na cibercultura". In: Revista Educação e Sociedade - Dossiê “letramento", Campinas-SP: CEDES, vol. 23, n. 81, p. 143-160, dez., 2002.

SOSTER, Vitor. Um estudo das temporalidades nas sequências narrativas de redações de pré-universitários. Relatório final de pesquisa. São Paulo: USPFFLCH, 2009.

STREET, Brain V. Literacy in theory and pratice. Cambridge: Cambridge University Press, 1984.

TFOUNI, Leda. Letramento e Alfabetização. São Paulo: Cortez, 1995.

TOULMIN, Stephen Edelston. Les usages de l'argumentation. Paris: Presses Universitaires de France, 1993.

TRAVAGLIA, Luiz Carlos. Um estudo textual-discursivo do verbo no português. Campinas, Tese de Doutorado, Campinas-SP: IEL - UNICAMP, 1991.

"A caracterização de categorias de texto: tipos, gêneros e espécies". In:

ALFA, vol. 51 n 1:39-79. São Paulo, 2007a. Disponível em:

http://www.alfa.ibilce.unesp.br/download/v51-1/03-Travaglia.pdf

. "Das relações possíveis entre tipos na composição de gêneros". Anais 4ำ

Simpósio Internacional de Estudos de Gêneros Textuais (4 SIGET).

Organizadores: Adair Bonini, Débora de Carvalho Figueiredo, Fábio José Rauen. Tubarão: UNISUL, 2007b.

Tipelementos e a construção de uma teoria tipológica geral de textos, 2002, disponível no endereço <http://www.mel.ileel.ufu.br/homepages 
/travaglia/artigos/artigo tipelementos e a construcao de uma teoria\%20tipologica geral de textos.pdf >, acesso em 19.12.2008.

TUTIN, Agnès. "Evaluative adjectives in academic writing in the humanities and social sciences". In: LOREZ-SANZ, Rosa; MUR-DUENAS, Pilar; LAFUENTE-MILAN, Enrique. Constructing Interpersonality: Multiple Perspectives on Written Academic Genres. Cambridge: Cambridge Scholars Publishing, 2010. (Artigo datado ano de 2008, disponível nos arquivos digitais do LIDILEM: http://w3.ugrenoble3.fr/lidilem/labo/file/evaluative adjectives interlae 2008 tutin.pdf.

VAN DIJK, Teun A., KINTSCH, W. Strategies of discourse comprehension. Nova lorque: Academic Press, 1983.

VIALA, Alain. "La dissertation fut d'abord um genre mondain snob". In: Pratiques, no. 68, Metz: CRESEF, dez. 1990.

VIANA Filho, Daniel Fernandes. $O$ gênero textual dissertação: um caso de referenciação anafórica. Dissertação de Mestrado. Recife: UFPE, 2006.

VIANNA, Heraldo Marelim. "Redação e medida da expressão escrita: algumas contribuições da pesquisa educacional”. In: Cadernos de Pesquisada Fundação Carlos Chagas. nํ16, p. 41-7, mar. 1976.

VIGNER, Gérard. "Argumenter et disserter: percours d'une écriture”. In: Pratiques, n‥ 68, . Metz: CRESEF, dez. 1990.

VION, R. "Le concept de modalisation”. In: Travaux, 18, pp. 209-229, 2003.

. "Dimensions enonciative, discursive et dialogique de la modalisation". In: Línguas e letras, estudos linguísticos, v. 8, no 15, pp. 193-224, Cascavel: Edunioeste, $2^{\circ}$ semestre de 2007.

VOLOCHINOV, V. N. (BAKHTIN). Discurso na vida e discurso na arte (sobre poética sociológica). Tradução de Carlos Alberto Faraco \& Cristóvão Tezza, s/d, [1926]. Texto de circulação acadêmica, mimeo.

WARNING, Rainer. "Pour une pragmatique du discours fictinnel". In: Poétique, 39, pp. 321-337, september, 1979.

WEBER, Max. "L'objectivité de la connaissance dans les sciences et la politique sociales". In: Essais sur la théorie de la science. Trad. do alemão para o francês por Julien Freund, Paris: Plon, 1965 [1904], Collection: Recherches en sciences humaines, $n^{\circ}$. 19. [versão eletrônica disponível no sitio http://classiques.uqac.ca/classiques/Weber/essais_theorie_science/Essais_science_ 1.pdf]. 
ANEXO 
FUVEST 2006

REDAÇÃO

\begin{abstract}
Texto 1
O trabalho nắo é uma essência atemporal do homem. Ele é uma invenção histórica $e$, como tal, pode ser transformado e mesmo desaparecer.
\end{abstract}

Adaptado de $A$. Simões

\section{Texto 2}

Há algumas décadas, pensava-se que o progresso técnico e o aumento da capacidade de produção permitinam que o trabalho ficasse razoavelmente fora de moda e a humanidade tivesse mais tempo para si mesma. Na verdade, - que se passa hoje é que uma parte da humanidade está se matando de tanto trabalhar, enquanto a outra parte está morrendo por falta de emprego.

M.A. Marques

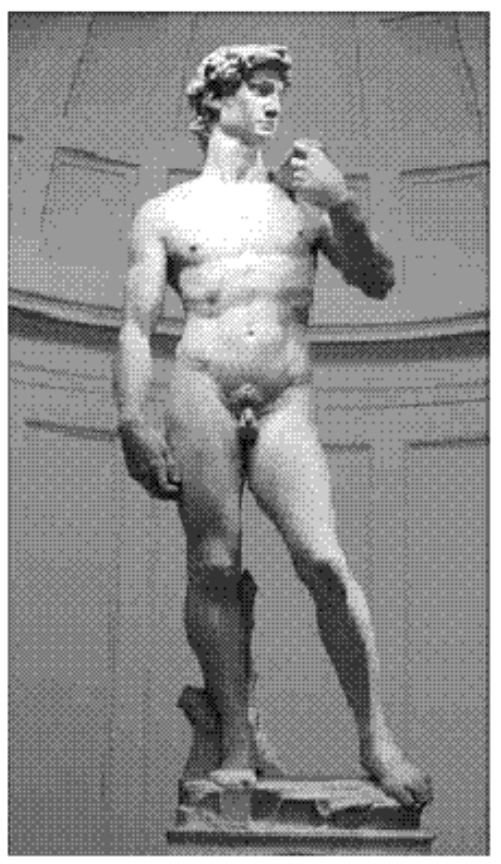

Texto 3

O trabalho de arte é um processo. Resulta de uma vida. Em 1501, Michelangelo retorna de viagem a Florença e concentra seu trabalho artístico em um grande bloco de mármore abandonado. Quatro anos mais tarde fica pronta a escultura "David".

Adaptado de site da Internet

INSTRUÇÃO: Os três textos acima apresentam diferentes visões de trabalho. O primeiro procura conceituar essa atividade e prever seu futuro. O segundo trata de suas condiçōes no mundo contemporâneo e o último, ilustrado pela famosa escultura de Michelangelo, refere-se ao trabalho de artista. Relacione esses três textos e com base nas idéias neles contidas, além de outras que julgue relevantes, redija uma DISSERTAÇÃO EM PROSA, argumentando sobre o que leu acima e também sobre os outros pontos que você tenha considerado pertinentes. 